DEVELOPING PRE-SERVICE TEACHER COMPETENCIES FOR ICT INTEGRATION THROUGH DESIGN TEAMS

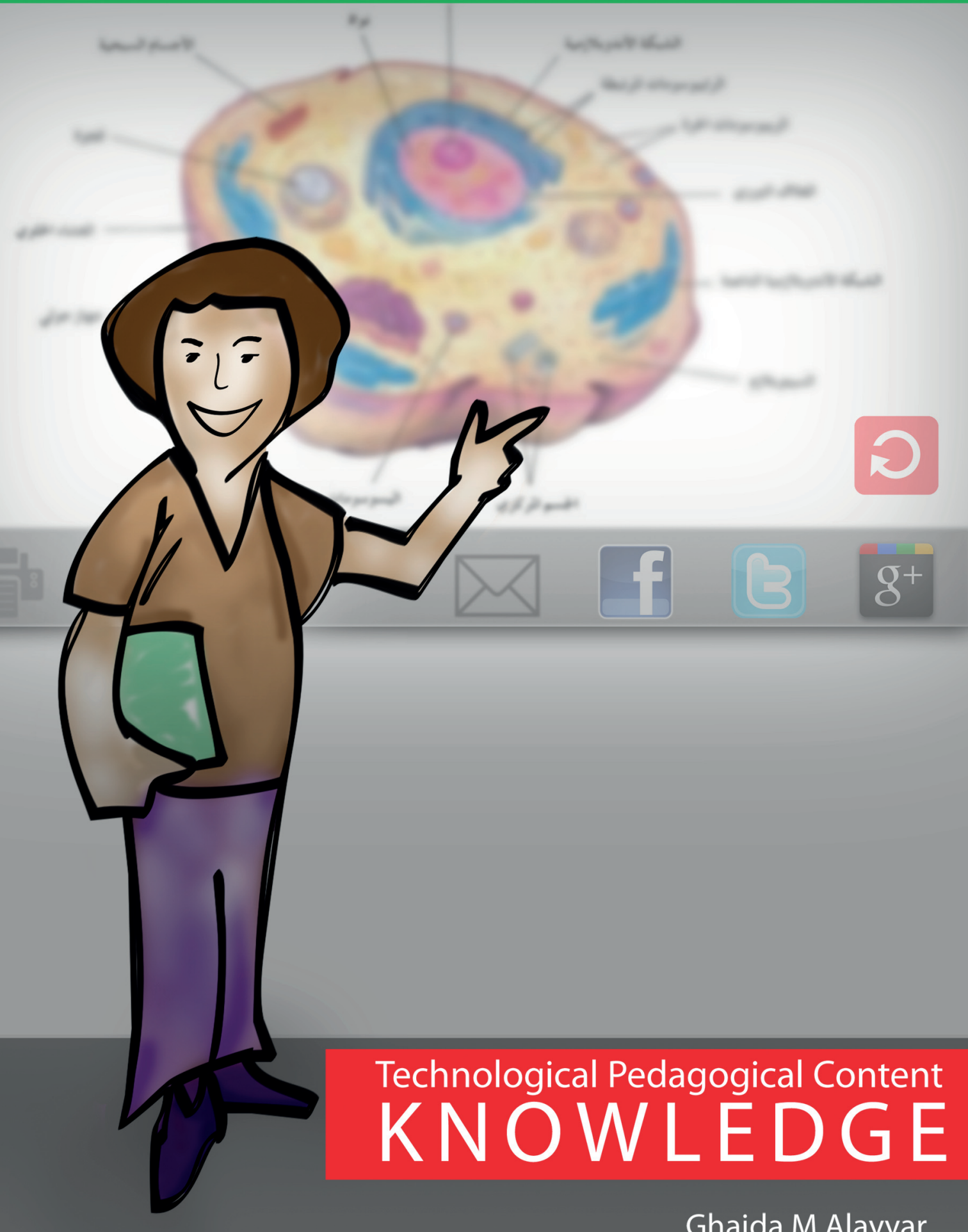

Ghaida M Alayyar 
DEVELOPING PRE-SERVICE TEACHER COMPETENCIES FOR ICT INTEGRATION THROUGH DESIGN TEAMS

Ghaida Alayyar 


\section{DOCTORAL COMMITTEE}

Chairman

Promotor

Assistant promotors

Members

Prof. Dr. P. J. C. Sleegers = University of Twente

Dr. E. van den Berg - University of Twente

Prof. dr. W. M. G. Jochems - University of Eindhoven

Prof. Dr. M. Valcke - University of Gent

Prof. Dr. S. Dijkstra = University of Twente

\section{Alayyar, G. M.}

Developing pre-service teacher competencies for ICT integration through design teams

Thesis University of Twente, Enschede.

ISBN 978-90-365-3234-1

DOI 10.3990/1.9789036532341

Layout: Sandra Schele

Press: Ipskamp Drukkers B.V. - Enschede

(C) Copyright, 2011, G.M. Alayyar 


\title{
DEVELOPING PRE-SERVICE TEACHER COMPETENCIES FOR ICT INTEGRATION THROUGH DESIGN TEAMS
}

\author{
DISSERTATION
}

to obtain

the degree of doctor at the University of Twente, on the authority of the rector magnificus, prof. dr. H. Brinksma,

on account of the decision of the graduation committee to be publicly defended on $7^{\text {th }}$ of September 2011 at 14.45

by

Ghaida Mamah Alayyar

born on the 27th of March 1967

in Kuwait 
Promotor

Prof. Dr. J. M. Pieters

Assistant promotors

Dr. J. M. Voogt

Dr. P. H. G. Fisser

This dissertation has been approved by the promotor and assistant promotors. 


\section{TABLE OF CONTENTS}

LIST OF FIGURES AND TABLES

1. INTRODUCTION 1

1.1 Introduction 1

1.2 Background 2

1.2.1 ICT integration in education 2

1.2.2 Technological Pedagogical Content Knowledge 3

1.2.3 Learning ICT by design and Design Teams 4

1.3 Context 6

1.3.1 Kuwait and ICT 6

1.3.2 Teacher's preparation program $\quad 8$

1.3.3 Science teacher preparation program at PAAET and ICT 8

1.4 Research approach 11

$\begin{array}{ll}\text { 1.4.1 Design based research } & 12\end{array}$

1.5 Research overview 13

2. ATTITUDES AND COMPETENCIES OF PRE-SERVICE SCIENCE TEACHERS IN KUWAIT TOWARD INFORMATION AND COMMUNICATION TECHNOLOGY: IMPLICATIONS FOR ICT INTEGRATION IN TEACHER EDUCATION

2.1 Introduction 15

2.2 Attitudes toward and skills of ICT use $\quad 17$

2.3 Research questions 19

2.4 Methodology 19

$\begin{array}{lll}2.4 .1 & \text { Participants } & 19\end{array}$

2.4.2 Instruments 20

2.5 Results 23 
2.6 Conclusion and discussion 28

2.6.1 The current curriculum and the role of ICT in particular 28

2.6.2 The attitudes and skills of the pre-service science teachers toward ICT

2.6.3 Pre-service science teachers' needs in relation to ICT 29

3. ICT INTEGRATION THROUGH DESIGN TEAMS IN SCIENCE TEACHER PREPARATION

3.1 Introduction 31

3.2 Theoretical framework $\quad 32$

3.3 Context of the study $\quad 35$

3.4 Intervention 36

3.5 Problem statement and research questions 38

3.6 Methodology 38

3.6.1 Participants 38

3.6.2 Instruments 38

3.6.3 Data analysis 44

3.7 Results 44

3.7.1 Change in TPACK 44

3.7.2 The change in ICT skills 46

3.7.3 The change in attitude toward ICT 47

3.7.4 Pre-service students' experiences with DTs 48

3.8 Conclusion and discussion $\quad 50$

3.8.1 Was there a change in the TPACK of the pre-service
teachers?

3.8.2 Did the ICT skills of the pre-service teachers change as a result of working in DTs? 50

3.8.3 Did the attitude of the pre-service teachers toward ICT change as a result of working in DTs? 51

3.8.4 How do the pre-service teachers experience working in DTs?

4. Developing Technological Pedagogical Content KNOWLEDGE IN PRE-SERVICE SCIENCE TEACHERS: THE POTENTIAL OF BLENDED SUPPORT FOR LEARNING

4.1 Introduction 56

4.2 Theoretical framework 58

4.3 The intervention 61 
4.4 Problem statement and research questions

4.5 Methodology

4.5.1 Participants 63

4.5.2 Instruments $\quad 63$

$\begin{array}{lll}\text { 4.5.3 Data analysis } & 66\end{array}$

4.6 Results 67

4.6.1 Development of knowledge and skills and attitude toward ICT while working in DTs 67

4.6.2 The difference between Human support and Blended support groups in relation to change in TPACK skills and attitude toward ICT

4.6.3 Blended support experience of the pre-service teachers' $\begin{array}{ll}\text { experience during the intervention } & 71\end{array}$

4.7 Conclusion and discussion

\section{PRE-SERVICE TEACHERS' COMPETENCIES FOR ICT} INTEGRATION: WHAT DO LEARNING OUTCOMES AND SELFREPORTED DATA TELL?

5.1 Introduction $\quad 78$

$\begin{array}{ll}5.2 \text { Theoretical framework } & 79\end{array}$

5.3 Pre-service teachers' development of TPACK through Design Teams

5.4 Problem statement and research questions 83

$\begin{array}{ll}5.5 \text { Method } & 83\end{array}$

$\begin{array}{lll}\text { 5.5.1 Participants } & 83\end{array}$

$\begin{array}{lll}5.5 .2 & \text { Instruments } & 84\end{array}$

5.5.3 Data analysis 90

$\begin{array}{ll}5.6 \text { Results } & 90\end{array}$

5.6.1 Evaluating the products 90

5.6.2 Learning outcomes after working in DTs 95

5.6.3 Self-reported measures and the learning outcomes of TPACK

$\begin{array}{ll}5.7 \text { Conclusion and discussion } & 99\end{array}$

6 EPILOGUE 103

6.1 Recapitulation: Aims and research questions 103

$\begin{array}{ll}6.2 \text { Research approach } & 105\end{array}$ 
6.3 Studies reported 105

6.3.1 1st study: Feasibility, perceptions, and attitudes 105

6.3.2 2nd study: TPACK and Teacher Design Teams 106

6.3.3 3rd study: Blended support for learning 118

6.3.4 4th study: Measuring TPACK development 119

6.4 Reflections of the research approach 111

6.5 Reflections on outcomes 112

6.5.1 The importance of the needs and context analysis 112

6.5.2 Effectiveness of Design Teams 113

6.5.3 Assessing TPACK development 113

6.6 Recommendations 116

6.6.1 Design Teams as approach for pre-service science teacher preparation at PAAET 116

6.6.2 ICT integration in the pre-service science teachers preparation curriculum at PAAET

6.6.3 Guidance for beginning teachers' on ICT integration after graduation 117

$\begin{array}{lll}\text { 6.6.4 Self- and peer evaluation } & 117\end{array}$

6.6.5 TPACK development through Design Teams for practicing teachers 118

$\begin{array}{ll}\text { REFERENCES } & 119\end{array}$

$\begin{array}{ll}\text { ENGLISH SUMMARY } & 135\end{array}$

$\begin{array}{ll}\text { DUTCH SUMMARY } & 143\end{array}$

$\begin{array}{ll}\text { APPENDICES } & 153\end{array}$ 


\section{LIST OF FIGURES AND TABLES}

\section{FIGURES}

1.1 The concept of TPACK 4

1.2 TPACK in the PAAET context 10

1.3 Design-based research, adopted from Reeves 13

3.1 The TPACK framework 33

3.2 Results of the questions related to TPACK experience from DT interview

\section{TABLES}

2.1 Scales, reliability and exemplary items of the program profile questionnaire

2.2 Singular items - Program Profile Questionnaire 21

2.3 Reliability of the attitude toward ICT questionnaire 22

2.4 Reliability of ICT Skills Questionnaire 23

2.5 Pre-service teachers' perception of their curriculum 23

2.6 Pre-service teachers' perception of their curriculum - singular items 24

2.7 Pre-service teachers' attitudes toward computers 26

2.8 Pre-service teachers' perception of their ICT skills 26

2.9 Pre-service teachers' needs in relation to ICT training - the reasons $\begin{array}{ll}\text { for addressing this need \& percentage of students } & 27\end{array}$

3.1 Tasks and activities during the course 37

3.2 List of instruments and related questions 39

3.3 Description of the TPACK survey 39

3.4 Description of the ICT skill tool 41

3.5 Description of the attitude toward ICT questionnaire 42

3.6 Description of the attitude toward teamwork questionnaire 42

3.7 The TPACK reflection rubric 43

3.8 A comparison of the pre-service teachers' perception of their TPACK 45 
3.9 Pre-service teachers' answers to TPACK interview part

3.10 A comparison of the pre-service teachers' pre \& post scores in ICT skill test

3.11 A comparison of the pre-service teachers' pre \& post attitude toward ICT

3.12 A comparison of the pre-service teachers' pre \& post attitude toward team

3.13 Summary of support and help needed by pre-service teachers during design process

4.1 Overview of the different instruments used in this intervention

4.2 Comparison of the pre-service teachers' perception of their TPACK

4.3 Comparison of pre-service teachers' pre \& post ICT skills

4.4 Comparison of the pre-service teachers' pre \& post attitude toward ICT

4.5 Comparison of the change in TPACK in HS and BS groups

4.6 Comparison of TPACK reflection question for HS and BS groups

4.7 Comparison of the attitude toward ICT for HS and BS groups

4.8 Summary of descriptive statistics for the score of ICT skill test for both groups

5.1 Overview of different way of collecting data about TPACK from the literatures

5.2 Overview of the different instruments used in this study

5.3 The TPACK definition rubric

5.4 TPACK reflection rubric

5.5 Example of TPACK survey statements for each domain

5.6 Summary of different examples of ICT-enhanced lesson with the added value of ICT to content

5.7 Description of different examples of ICT-enhanced lesson with the added value of ICT to pedagogy

5.8 Descriptive statistics of learning outcomes

5.9 Comparison of the pre-service teachers ICT skills

5.10 Pearson Correlation Matrix among learning outcomes

5.11 Comparison of the pre-service teachers' perception of their TPACK $\quad 97$

5.12 Pearson correlation matrix between TPACK domains 97

5.13 Pearson correlation matrix between TPACK different domains 98

5.14 Pearson correlation coefficient between TPACK domains and learning outcomes 


\section{CHAPTER 1}

\section{Introduction}

This chapter describes the backgrounds of the study. It begins by introducing Technological Pedagogical Content Knowledge and Learning Technology by Design as a framework for this study. The context of the study, the pre-service science teacher education program at the Public Authority of Applied Education and Training (PAAET) in Kuwait, is described and the problems related to the way pre-service science teachers at PAAET are prepared for ICT integration are discussed. This is followed by a description of the research questions and the rational for the research approach adopted in this study. The chapter ends with an overview of the thesis.

\subsection{INTRODUCTION}

Jimoyiannis (2010) argued that true learning in the $21^{\text {st }}$ century requires students being able to use ICT, not only for enhancing the memorization of facts, but also for problem solving in real world settings. This means that there is an increased and urgent need to develop teachers who are able to integrate ICT in their teaching practice. Teacher preparation programs are providing their students with a variety of ICT tools and opportunities to learn and practice ICT-related skills, however many studies report that pre-service teachers are unable to use or integrate ICT in their own teaching practices (e.g. Chen, 2008; Fishman \& Davis, 2006; Palak \& Walls, 2009; Zhao, Pugh \& Sheldon, 2002), especially when the ICT courses or training programs focus mainly on the acquisition of basic ICT skills. Several studies have shown that the acquisition of basic ICT skills are not sufficient to develop the ability to teach effectively with ICT (Doering, Veletsianos, Scharber \& Miller, 2009; Jimoyiannis, 2008; Wetzel, Wilhelm \& Williams, 2004; Zhao \& Bryant, 2006). For teachers to be able to integrate ICT in teaching they need an intensive course on the pedagogical use of ICT for a certain subject (Baylor \& Ritchie, 2002; Becker, 2001). Kereluik, Mishra and Koehler (2010) argued that "teachers need to know how to integrate technologies into their teaching in 
ways that are flexible, tolerate ambiguity, and connect to deep subject matter learning" (p. 3892). A possible explanation for the lack of teachers' ability to use the potential of ICT to solve pedagogical problems is that teachers experience difficulty in understanding the complex relationships between ICT, pedagogy and content, because these three domains are often taught in isolation in teacher education programs (Koehler et al., 2004; Mishra \& Koehler, 2006; Zhao, 2003).

\subsection{BACKGROUND}

\subsubsection{ICT integration in education}

ICT integration implies that teachers are able to use ICT to introduce, reinforce, extend, enrich, and assess student's mastery of new concepts in a natural, flawless act of selecting the right tool for the learning task (Kelly, 2002). Having powerful tools accessible for both teachers and learners, teachers need to realize that their role is changing when they realize that they can no longer be the source of all information and direct all learning. So teachers will become a facilitator of learning who will foster self-motivated, self-regulated learning in his or her students.

Research findings over the past 20 years provided evidence of the positive effects of the use of ICT on the students' learning (e.g. Mumtaz, 2000). Recent studies also indicate that effective use of ICT has the potential to improve students' learning and classroom experience (Gifford, 2004; Margerum-Leys \& Marx, 2002). Hicks (2006) stated that teachers with more experience in using ICT in education maintain higher expectations of students' learning. Churchill (2009) argued that ICT adds a new dimension to teaching effectiveness by enabling teachers to do things that might not be possible within the traditional classroom. Using blogs for example to publish own writings, discuss topics of interest, peer review and collaboration provides a new spectrum of teacher-student and student-student interactions beyond the classroom or school environment.

Godfrey (as cited in Sang, Valcke, Braak \& Tondeur, 2010) summarizes the potential of ICT in education as follows: 'ICT presents a rich learning environment, allowing the learners to adopt multiple perspectives on complex phenomena, to foster flexible knowledge construction in complex learning domains, and to cater individual differences ( $p .103) '$. This implies the shift of the teacher role from a lecturer to a facilitator, and this signifies that the learning environment will become more student-centred instead of teacher-centred. 
ICT has fundamentally changed many aspects of our lives. Teachers and teachers educator are not focusing any more on the decision whether to adopt ICT in education, they are focusing more toward the implementation and integration process (e.g. Angeli \& Valanides, 2009). In order to be successful in this, it is important that teachers have sufficient ICT competencies and are aware of the pedagogical use of ICT in education. Next to the ICT competencies research has found the attitude toward computers and computer self-efficacy are also predictors of ICT use among teachers (Christensen \& Knezek, 2008; Vannatta \& Fordham, 2004).

Harris, Mishra, and Koehler (2009) argued that ICT integration approaches that 'did not reflect disciplinary knowledge difference, the corresponding process for developing such knowledge, and the critical role of context ultimately are of limited utility and significance, as they ignore the full complexity of the dynamic realities of teaching effectively with technology (p. 395)'. This implies that teachers should also be aware that introducing new ICT tool in teaching not only change the use of tools in teaching but also what we teach and how we teach, which is an important and often overlooked aspect of many ICT integration interventions (Harris et al., 2009).

\subsubsection{Technological Pedagogical Content Knowledge (TPACK)}

Keating and Evans (2001) found that pre-service teachers felt comfortable with ICT in their schoolwork and daily practices, however felt unconfident to use ICT in their future classroom. One possible reason is that the pre-service teachers were lacking "Technological Pedagogical Content Knowledge" (TPACK) (Koehler \& Mishra, 2008; Koehler, Mishra, Hershey, \& Peruski, 2004; Mishra \&, Koehler 2006). TPACK is a framework to understand and describe the kinds of knowledge needed by a teacher for effective technology integration. The idea of pedagogical content knowledge (PCK) without the explicit technology aspect was first described by Shulman (1987) and TPACK builds on this idea through the inclusion of technology. The TPACK framework argues that effective ICT integration for teaching specific content or subject matter requires understanding of the relationships between three components: ICT/Technology (T), Pedagogy (P), and Content $(\mathrm{C})$ in a certain context. TPACK can be defined as an understanding that emerges from the interaction of Content, Pedagogical, and Technological Knowledge (Koehler \& Mishra, 2008). See Figure 1.1 for a graphical representation. 


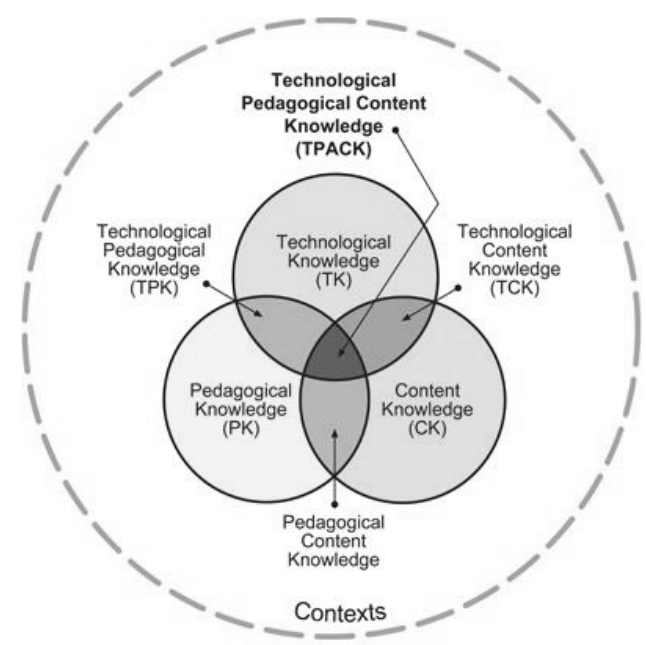

Figure 1.1 The concept of TPACK (adopted from Koehler \& Mishra, 2008)

Or, as Koehler \& Mishra (2008) indicate "At the heart of good teaching with technology are three core components: content, pedagogy, and technology and the relationship between them" (Koehler \& Mishra, 2008, p 11-12). The TPACK framework gives an overview of three primary forms of knowledge a teacher needs to possess or acquire for ICT integration into their teaching: Technological Knowledge (TK), Pedagogical Knowledge (PK) and Content Knowledge (CK), as well as the interplay and intersections between them.

The intersection between the different knowledge domains produces Pedagogical Content Knowledge (PCK) which is the knowledge of teaching specific content; as addressed by Shulman (1987). Technological Pedagogical Knowledge (TPK) is an understanding of how teaching and learning changes when particular ICT application is used. Technological Content Knowledge (TCK) is an understanding of the manner in which ICT and content influence and constrains one another. TPACK is the intersection of all three bodies of knowledge (TK, CK \& PK). Understanding of TPACK is above and beyond understanding of TK,CK, and PK in isolation, that is emerge from an interaction of content, pedagogy and technology.

\subsubsection{Learning ICT by design and Design Teams}

Literature suggests that needs-based, collaborative professional development is effective in developing the competencies teachers need to adequately integrate 
ICT in classroom practice (Chandra-Handa, 2001; Figg, 2000; Haughey, 2002; MacDonald, 2008). Kay (2007) conducted a study to compare four strategies used by pre-service teachers to learn about ICT. He found that collaborative strategies to learning was the best predictor of gains in ICT knowledge, and that authentic tasks and collaborative strategies were significant predictors of teacher use of computers in the classroom. Koehler and Mishra (2005) recommended that involving teachers in collaborative authentic problem solving tasks with ICT is an effective way to learn about ICT and ICT integration processes and to develop TPACK, which they called 'learning technology by design'.

The learning technology by design approach seeks to put teachers in roles as designers of ICT enhanced environment as they work collaboratively in small groups to develop ICT-solutions to authentic pedagogical problems. By participating in the design process, teachers build competencies that are sensitive to the subject matter (instead of learning the technology in general) and to specific instructional goals (instead of general ones) relevant for addressing the subject matter. In their view every act of design is always a process of weaving together components of ICT, content, and pedagogy (Mishra \& Koehler, 2003).

Traditional approaches of learning to use ICT in education will make teachers consumers of knowledge about ICT tools, with the hope that they will be able to apply this general knowledge to solving problems in their specific classrooms (Koehler \& Mishra, 2005). The learning technology by design approach is based upon different educational strategies that addresses the potential of design based activities for learning such as constructivism or constructionism (Cole, 1997; Harel, 1991; Harel \& Papert, 1991;Vygotsky, 1978) and the theory of problembased learning (Blumenfeld, Marx, Soloway, \& Krajcik, 1996; Krajcik et. al., 1998). Problem-based learning and learning technology by design often occurs over an extended period of time; they are learner-centred, interdisciplinary, ill-structured, and related to real world by engaging students in authentic activities. 


\subsection{CONTEXT}

\subsubsection{Kuwait and ICT}

Albedah (personal communication, May 17, 2011) stated that Kuwaitis in general and Kuwaiti youth in particular have developed a taste for new technologies over the past 2 decades. This passion has evolved around new appliances in general and telecommunication devices in particular such as pagers and mobile telephones. Other technical advances were slower to propagate in the society. Email and internet have only became a popular household item in the past decade. Businesses were pioneers in experimenting with new technologies while utilization of such technologies in education is next to non-existent.

The initial uses of the internet within the youth population was limited to social networking and exploring relationships with the opposite gender. By using chatrooms and messaging services. Yet in a few years, the internet became a haven for expression and voicing opinions in political and social arenas. Traffic was directed towards forums, blogs and most recently to Facebook and Twitter. Social media has become instrumental in major political changes and parliamentary elections. Specific interest groups were created and developed through these electronic media channels (Albedah, personal communication, May 17, 2011).

The Kuwaiti government believes that the controlled deployment of ICT in schools will create exciting possibilities for learners and teachers to engage in new ways of information acquisition and analysis, as well as new opportunities to create knowledge. ICT will enhance access to education and will improve the quality of education delivery in a more equitable way across the country. The government is therefore committed to a comprehensive program of rapid deployment and utilization of ICT within schools in order to transform the education system and improve the lives of our people (National ICT in Education Strategy, 2008).

The Ministry of Education (MoE) in Kuwait took several practical steps to implement ICT in the educational process. In academic year (2000-2001) the MoE started facilitating and providing the International Computer Driving Licence (ICDL) training course for in-service teachers to equip them with the practical skills needed for the ICDL qualification. Later on the MoE started to use incentives for teachers to encourage them to obtain the ICDL. Computers were introduced to all schools and to various stages of public education in 2000-2001. 
Later on internet connections were provided for all the ministry's schools. Nowadays this evolved to include all kindergartens (ESCWA, 2009 a).

During 2008 the MoE issued the strategy of e-learning and started its implementation in 2009 (MoE, 2008). In the e-learning strategy of the MoE the Blended learning mode of e-learning was adopted. The main objectives of the elearning strategy of the MoE in Kuwait was: to improve teaching and learning by introducing ICT, to increase student centred learning, to create an environment for immediate interactions between learners and the teacher, to overcome the limits of time and place in the educational process, and to avoid the emergence of new generations suffering from technological illiteracy.

Beside the MoE efforts for ICT integration in general, the MoE introduced a new science curriculum for primary schools in the academic year 2009-2010, with a main focus to link science with ICT, and toward more student-centred learning (Saleh, personal communication, April 5, 2011).

The MoE was optimistic in her thinking that by introducing ICT to schools and providing in-service teachers with the technological skills this would lead to ICT integration into teaching and learning. However, this is not the case. Although computers and ICT were integrated or used in everyday personal life, and have affected changes in different aspects of life, when it comes to actual classroom use we found that many teachers know about ICT skills but do not know when and how to use them in their practices. ICT is mainly used by teachers for presenting the lesson (replaces the black board), word processing or drill and practice and not for higher-level applications.

Because most ICT tools are developed for business sectors, teachers need to be innovative and creative in repurposing the use of ICT tools to be integrated effectively in their classroom; to deliver concepts and theories easily to students and provide them with better education (Koehler \& Mishra, 2005; Mishra \& Koehler, 2003; 2009; Mishra, Koehler, \& Kereluik 2009). Therefore, teachers' preparation program should enhance and facilitate this vision by preparing their students for ICT integration to fulfil their future role in the rich ICT school/classroom environment. Therefore, it is crucial that teacher preparation programs develop an environment that will help teachers to experience and practice teaching with ICT. 


\subsubsection{Teacher's preparation program}

Teacher education in Kuwait is offered by two main institutions, the Faculty of Education at Kuwait University, and The College of Basic Education at the Public Authority of Applied Education and Training (PAAET). Learning at those institutions is totally free for Kuwaiti citizens.

The Faculty of Education at Kuwait University offers a four-year bachelor degree program for kindergarten and primary school teachers, Bachelor of Arts \& Education, and Bachelor of Science \& Education programs for Intermediate and Secondary school teachers. The instruction language at the College of Education is mostly Arabic. The faculty of Education at Kuwait University also offers higher study programs for teachers by which teachers can obtain a teaching diploma or a master degree in teaching.

The College of Basic Education at PAAET offers a four-year bachelor degree program taught totally in Arabic for primary school teachers with different specialities. The College of Basic Education offers programs in the following specializations: Islamic Education, Arabic Language, English Language, Science, Mathematics, Art Education, Physical Education and Sport, Library \& Information Science, Educational Technology, Music, Kindergarten, Home Economics, Interior Design, and Computer Teaching.

Both institutions maintain a close cooperation with the Ministry of Education to ensure quality in education, expediting educational reform and generating a competent workforce for meeting the demands of society and in response to developmental needs. It also organizes and participates in national and international seminars, symposia, and conferences for the development of education and improving the quality of life, in addition to a dynamic social, consultative and training role.

In this research, we will focus on teacher preparation program at PAAET especially on the Science Teacher Preparation Program.

\subsubsection{Science teacher preparation program at PAAET and ICT}

The science teacher preparation program at PAAET is a four-year tertiary program, by which students have to successfully complete 130 credits in order to graduate: 122 credits for general, specialized and practical studies, and eight for in-school training (PAAET, 2010). Only female students are accepted to join this program due to the fact that almost all primary public schools in the State 
of Kuwait are totally equipped with female staff regardless whether these schools are for girls or boys.

Instructors at the science teacher preparation program are mainly dependent on lecture-based instruction by which teachers are doing most of the talking and intellectual work, while students are passive receptacles of the information provided (Alayyar, 2007). This teacher-centred method allows the teacher to quickly convey lots of information to students. This could be a useful strategy for recall or rote learning, especially when the classes are overcrowded as often the case in Kuwait. However, the teacher-centred method might not be an effective way for science teaching, because instruction alone is not enough for conceptual understanding. In learning science, students not only need knowledge but also communication skills, problem solving skills, and creative and critical thinking skills (Zakaria \& Iksan, 2006).

Alayyar (2007) noticed that the instructors at the science teacher preparation program use traditional tools for teaching without or with limited integration of ICT in their courses due to two main reasons: a lack of ICT skills (especially related to older staff members) or a lack of ICT integration skills. Some instructors know about ICT applications, but do not know how to use them effectively in their courses. In general ICT is used by the staff members for the grading system, and for printing hand-outs and course syllabi (Alayyar, 2007).

Students at the science teacher preparation program do have an 'Introduction to Computer' course that is a two-credit optional course. In this course pre-service teachers learn basic computing skills such as working with the operating system and word processing, spread sheets, and presentations. Next to the optional computer literacy course there are two obligatory two-credit courses: 'Introduction to Educational Technology', which is a theoretical course, and 'Workshop for Educational Media Production', which is focused on the production of traditional media such as transparencies, 3Dstatic models, and posters.

Based on the above information it seems that the pre-service science teachers are not fully prepared to integrate ICT in their teaching practice. This is consistent with the analysis of deficiencies for higher education in Kuwait done by Alhammar (2006). She found that pre-service teachers are lacking the adequate professional and technological skills. There is an inadequate upgrading and training for instructors and teachers in order to adopt and implement new ICT for teaching and learning. 
The science teacher preparation program is faced with the challenge of preparing their students with the competencies needed for ICT integration. For teachers to be able to use ICT in their classroom, they need to develop the knowledge that enables them to translate the potential of ICT for solving pedagogical problems. This kind of knowledge about technology is situated in the context where the technology should be used (Zhao, 2003). In order to integrate ICT in education, the teacher preparation program needs to provide their candidates with this kind of knowledge, which enables them to integrate ICT in their future classroom effectively. According to Zhao teachers knowledge of ICT consists of three main elements: a) knowledge of problems or situations that can be solved with technology, b) knowledge of what kind of technology that can solve these kind of problems and c) knowledge on how this ICT application can solve the specified problem.

If the concept of TPACK is related to the context of PAAET, it can be seen that the Technological Knowledge (TK) during the science teacher preparation program at PAAET is treated separately as a stand-alone type of knowledge, and no real link exists between the technological skills or knowledge that the students gain during the program with other kinds of Pedagogical or Content Knowledge gained during the whole program. In other words, the teachers that graduate from the science teacher preparation program are provided with different kind of knowledge, such as Content Knowledge (CK), Pedagogical Knowledge (PK), Technological Knowledge (TK) and there is a relationship between Pedagogical and Content Knowledge (known as Pedagogical Content Knowledge (PCK)), but there is no emphasis on Technological Pedagogical Content knowledge (TPACK) as shown in Figure 1.2.

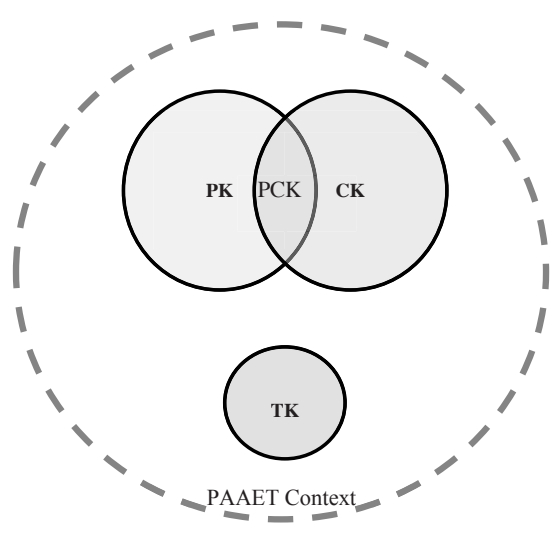

Figure 1.2 TPACK in the PAAET context 
The previous figure suggests that there is a problem in the context of PAAET in the way pre-service teachers are prepared to effectively integrate ICT in teaching and learning. As Selinger (2001) and Wetzel, Wilhelm, and Williams (2004) say, there is no doubt that basic computing skills constitute the foundation of ICT literacy, but they are not enough for adequately prepare teachers to teach with ICT, especially when computing skills are taught separately from pedagogy and content. It is clear that the integration of ICT is beyond the simple skills offered at computer literacy courses.

Taking that to account it means that to integrate ICT effectively at the science teacher preparation program at PAAET, it is necessary to teach ICT in the context that govern rich connections between ICT (T), the subject matter (C), and the means of teaching $(\mathrm{P})$. In order to accomplish this pre-service teachers need to be introduced to the TPACK framework and need to work in an environment that is conducive for understanding TPACK. This was accomplished by introducing the TPACK framework to the pre-service teachers at PAAET and to engage them in Design Teams (DTs) in which they were involved in rich design activities, in which they integrated the three components of the TPACK framework: knowledge of their Content (Science) (CK), Pedagogy (PK), and ICT (TK). During their engagement in design activities they were active learners and they were learning by doing and experimenting with different ICT tools to solve the selected problems in primary school science education. They designed an ICTproduct that is sensitive to their specific science topic and instructional goals, and each member of the design team taught and learnt from other members of the team.

\subsection{RESEARCH APPROACH}

The main aim of this study was to prepare the pre-service science teachers at PAAET with the skills and knowledge and attitudes needed to be ICT-integrating teachers. According to this main aim of the study; the main research question was:

"What are the effects of working in Design Teams on the knowledge, skills and attitudes pre-service teachers need to be able to integrate ICT in their future teaching practice?" 
From the main research question, four sub questions were derived. The subquestions are:

1. What are the perceptions, attitudes, and needs of pre-service teachers in relation to ICT integration and what are the conditions for successful usage of ICT at PAAET?

2. What changes could be observed in Technological Pedagogical Content Knowledge (TPACK), ICT skills, and attitudes toward ICT of pre-service science teachers who participated in Design Teams?

3. What differential effects do Human Support and Blended Support have on pre-service teachers' development of TPACK, and their attitude and skills related to ICT?

4. What TPACK learning outcomes do pre-service teachers demonstrate after working in Design Teams on ICT integration and how are these TPACK learning outcomes related to their self-reported TPACK?

\subsubsection{Design based research}

This study adopted design based research as the approach for this study. Wang and Hannafin (2005) defined design-based research as "a systematic but flexible methodology aimed to improve educational practices through iterative analysis, design, development, and implementation, based on collaboration among researchers and practitioners in real-world settings, and leading to contextually-sensitive design principles and theories" (p. 6). Reeves (2000) indicated that a researcher with developmental goals needs to focus on the dual objectives. To develop creative approaches for solving performance or teaching/learning problems, and at the same time construct a body of design principles that could be used to guide effort for future developments. Barab and Squire (2004) added that "Design-based research focuses on understanding the messiness of real-world practice, with context being a core part of the story and not an extraneous variable to be trivialized".

The main criteria of design-based research are dependence on local ownership to observe and address complex problems or phenomena in their natural settings. This needs flexible design, revisions, multiple dependent variables, and capturing social interaction. In addition, participants in design-based research are not "subjects" to be treated; however, they are treated as co-participants in both the design and the analysis (Barab \& Squire, 2004). Design-based research has a simultaneous goal of developing effective learning environments and using these 
learning environments as natural laboratories for studying learning and teaching processes (Sandoval \& Bell, 2004). Design-based research is challenging because the researcher not only needs to understand what is happening in a particular context, the researcher should also be able to show the relevance of the findings from the context of intervention to other context.

Reeves (2000) created a model of design-based research for the domain of instructional technology that highlights four main phases: addressing complex problems in a real context in collaboration with practitioners; developing the solution by integrating known hypothetical design principles with technological affordances to render plausible solutions to these complex problems; iterative refinement; and reflection to define new design principles. This process of design-based research studies is illustrated in Figure 1.3.

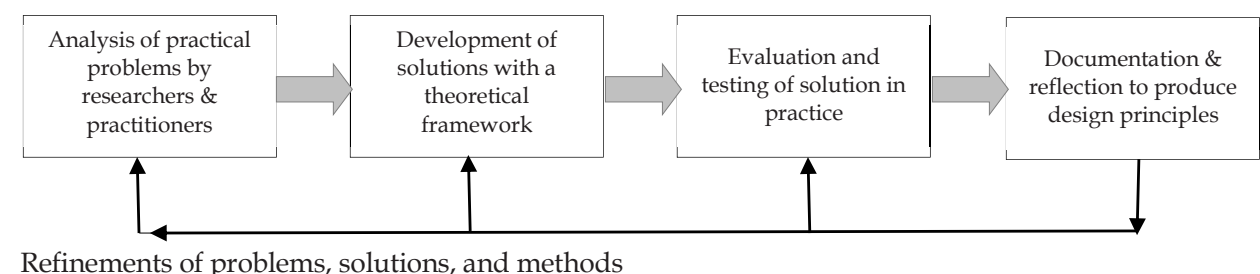

Figure 1.3 Design-based research, adopted from Reeves (2000)

The study activities were guided by the previous description of design-based research to develop a course (professional development) for the pre-service science teachers at PAAET to equip them with competencies needed to be able to integrate ICT in their future classroom practices.

\subsection{RESEARCH OVERVIEW}

This study aimed to prepare pre-service science teachers for ICT integration. To achieve this aim the study was conducted through four different sub-studies:

In the first study (Chapter 2, 'Context Analysis') aimed to answer the first research question: "What are the perceptions, attitudes, and needs of pre-service teachers in relation to ICT integration and what are the conditions for successful usage of 
ICT at PAAET?". To answer the first research questions, pre-service teachers' perceptions of their current curriculum especially in relation to ICT, their attitude toward ICT, their ICT skills and their ICT training needs were assessed.

The second study (Chapter 3, 'Pilot Testing'), aimed to answer the second research question: ' What changes could be observed in Technological Pedagogical Content Knowledge (TPACK), ICT skills, and attitudes toward ICT of pre-service science teachers who participated in Design Teams?'. The pre-service teachers worked in Design Teams and were coached by ICT, pedagogy, and content experts, to find a ICT-related solution for an authentic educational problem which teachers could encounter in their teaching practice.

The third study (Chapter 4, 'Exploring the potential of blended support') was conducted to answer the third research question: 'What differential effects do Human Support and Blended Support have on pre-service teachers' development of TPACK, and their attitude and skills related to ICT?'. The pre-service teachers were separated into two groups, the first group was offered human support (HS) for a ICT, pedagogy and content expert (similar to the previous study) and the second group was offered blended support (BS), by which they had access to an online portal with different tutorials and examples. In addition they had the opportunity to meet with the different experts whenever needed.

The fourth study (Chapter 5, 'What do learning outcomes and self-reported data tell?'), aimed to answer the fourth research question: 'What TPACK learning outcomes do pre-service teachers demonstrate after working in Design Teams on ICT integration and how are these TPACK learning outcomes related to their self-reported TPACK?'. For this purpose TPACK learning outcomes as showed by pre-service students' presentations, lesson plans, ICT products, and ICT skill test were analyzed to determine whether the pre-service teachers had developed an understanding of TPACK and were able to integrate ICT in lesson plans and learning products through working in Design Teams. In addition pre-service teachers' self-reported data on their TPACK were analyzed and differences between TPACK learning outcomes and self-report data were explored. 


\title{
CHAPTER 2
}

\section{Attitudes and competencies of pre-service science teachers in Kuwait toward information and communication technology: Implications for ICT integration in teacher education}

\begin{abstract}
This study aims to assess the perceptions of pre-service science teachers at the Public Authority of Applied Education and Training (PAAET) in Kuwait about a) their current curriculum especially in relation to ICT, b) their attitudes toward and skills of ICT use, and c) their ICT training needs. The pre-service science teachers' perception of the current teacher education curriculum is that their program is not preparing them as ICT-integrating teachers. While these teachers have a positive attitude toward computers and are computer literate, they have expressed an urgent need for training in the pedagogical use of ICT. In this paper we discuss the implications of these findings for the science teacher education program.
\end{abstract}

\subsection{INTRODUCTION}

Recent advances in Information and Communication Technology (ICT) continue to change our daily lives. As a result, there is growing interest in ICT integration within education. Since teachers play a critical role in the teaching and learning process, it is crucial that they have good ICT skills and know how and when to use ICT effectively in their daily classroom practice. This in turn means that teacher preparation programs should help pre-service teachers understand how ICT can be used to teach educational content in rich and meaningful ways

Alayyar, G., Fisser, P. \& Voogt, J. (submitted). Attitudes and competencies of pre-service science Teachers in Kuwait toward Information and Communication Technology: Implications for ICT integration in Teacher Education. Educational Technology Research and Development. 
(Keating \& Evans, 2001). Teacher preparation programs should therefore provide their students with the experiences and knowledge necessary to use ICT effectively in their future classroom practice.

Unfortunately, this is currently not the case in the teacher preparation program at the Public Authority of Applied Education \& Training (PAAET) in Kuwait. The teacher preparation program, and in particular the science teacher preparation program at PAAET on which this study focuses, includes some courses on ICT skills, but only as stand-alone ICT skills courses, on the assumption that acquiring ICT skills will lead automatically to effective integration of ICT by preservice teachers in the future. The ICT skills courses provide students with basic ICT skills and emphasize mastery of hardware and software, but with limited exposure to the possibilities of ICT for educational practice (Adamy \& Boulmetis, 2006; Brown \& Warschauer, 2006). Previous research stressed the importance of basic ICT skills as the foundation for ICT literacy; however, basic ICT skills are not enough to prepare pre-service teachers to effectively use ICT in their practice (Angeli \& Valanides, 2005; Wetzel, Wilhelm \& Williams, 2004). Researchers have found a positive correlation between teachers' ability to integrate ICT in their practice with courses that taught ICT as part of the methods or curriculum (e.g., Keeler, 2008; Moursund, \& Bielefeldt, 1999).

The science teacher preparation program at PAAET prepares science teachers for the primary level. It is a four-year tertiary program. Only female students are accepted to join the program due to the fact that almost all primary public schools in Kuwait have only female staff, regardless of whether these schools are for girls or boys. A review of the curriculum plan and the course descriptions shows that the program has limited or no integration of ICT. Students at the science teacher preparation program have an "Introduction to Computer" course that is a two-credit optional course, in which pre-service teachers learn basic computing skills such as working with the operating system and with word processing, spread sheets, and presentations. Next to the optional computer literacy course, there are two obligatory two-credit courses: "Introduction to educational technology," a theoretical course, and "Workshop for educational media production," a course focused on the production of traditional media such as transparencies, 3Dstatic models, and posters. From this review, it appears that the program does not give its pre-service teachers sufficient chances to learn about the opportunities of ICT for teaching and learning science and integrating ICT in science education. 
The purpose of this study is to inform the development of ICT integration in the science teacher preparation program. The study therefore aims to assess the perceptions of pre-service science teachers at PAAET regarding their current curriculum, especially in relation to ICT, their attitudes toward and skills of ICT use, and their ICT training needs.

\subsection{ATTITUDES TOWARD AND SKILLS OF ICT USE}

"Attitude" is defined as the tendency of an individual to respond favourably or unfavourably to a certain thing (see Ajzen \& Fishbein, 1980; Eagley \& Chaiken, 1998; Fishbein \& Ajzen, 1972). Although theorists admitted that attitude may be difficult to measure or may be imprecise for varying reasons (Baker \& O'Neil, 1987; Gable, 1986; Gable \& Wolf, 1993; Thurstone \& Chave, 1929), they believe it is tied to behaviour (Gagné, 1985; Kay, 1992; Krathwohl, Bloom, \& Masia, 1964; Liaw, 2000), and they stress that attitude helps in predicting human behaviour (Ajzen \& Fishbein, 1980). Zimbardo, Ebbesen \& Maslach (1977), argued that changing individuals' behaviour is possible once their attitudes have been identified. Zimbardo et al. (1977) clarified that although predicting individual behaviour is difficult, changing people's attitudes leads to changing their behaviours.

Among the factors that affect successful use of computers in the classroom are teachers' attitudes toward computers (Huang \& Liaw, 2005). "Attitude toward ICT" can be defined as the level of affect one has for ICT (Duran, 2003). Zhao, Tan, and Mishra (2001) found that teachers' attitudes toward computer use are directly related to their use of computers in the classroom. Bullock (2004), on the other hand, found that teachers' attitudes are a major enabling/disabling factor in their adoption of ICT. In fact, the development of teachers' positive attitude toward technology is a key factor not only for enhancing computer integration, but also for avoiding teachers' resistance to computer use (Watson, 1998 a). Teachers' positive attitude toward computer use is critical for their adoption of ICT in the classroom, as well as for their personal use (Christensen, 1998; Kersaint, Horton, Stohl \& Garofalo, 2003; Knezek \& Christensen, 2008; Tsitouridou \& Vryzas, 2003). Teachers' attitudes toward computers often determine the success or failure of an initiative to introduce ICT in the classroom (Jett \& Schafer, 1993; Supovitz \& Turner, 2000; Woodrow, 1991). 
Moreover, it was found that teachers' attitudes toward computers could affect their level of confidence in ICT (Delcourt \& Kinzie, 1993). Those who feel comfortable in using ICT usually try to incorporate it into their teaching (Kersaint et al., 2003). Milbrath and Kinzie (2000) found that teachers must have positive attitudes toward and feel confident in using ICT in the classroom in order to be effective models for their students. Christensen (1998) states that teachers' attitude toward computers affect not only their own computer experiences, but also the experiences of their students.

Researchers concluded that teachers' attitude toward computers influence and predict computer use for teaching (Kellenberger \& Hendricks, 2003; Knezek \& Christensen, 2008; Myers \& Halpin, 2002). In fact, assessing teachers' attitudes toward ICT use may provide useful insights into the process of ICT integration, ICT acceptance, and ICT usage in teaching and learning and could be a good predictor for teachers' future use of ICT.

However, having a positive attitude toward ICT is not enough for teachers to use ICT daily in their classrooms unless their attitudes are also supported by the necessary skills to use ICT and access to ICT tools (Knezek \& Christensen, 2008). Knezek and Christensen (2008) indicate that skills in the use of ICT are a prerequisite to successful employment of ICT in education. This was supported by similar findings in other studies (see for instance Albirini, 2006; Mumtaz, 2000; Tearle, 2003).

Although many teachers believe computers are important tools for education, they avoid using computers in their instruction because they lack confidence about using computers due to lack of knowledge and skills. Many studies showed that teachers' computer skill is a significant predictor of their attitudes toward computers (see for instance Summers, 1990). Baylor and Ritchie (2002) indicated that "regardless of the amount of technology and its sophistication, technology will not be used unless faculty members have the skills, knowledge and attitudes necessary to infuse it into the curriculum" (p. 398). From what was mentioned earlier, we can assume that attitude plays a critical role in the acceptance or avoidance of innovation in general. In addition, it was found that the ICT skills of teachers constitute another important factor besides attitude toward ICT use in teachers' integration of ICT in the classroom. In view of what has been mentioned, we conclude that it is important to measure the attitudes of pre-service teachers toward ICT and their ICT skills level to inform the development of ICT integration in the science teacher preparation program. 


\subsection{RESEARCH QUESTIONS}

This study aims to assess pre-service science teachers' attitudes and skills toward ICT and their perceptions of the science education curriculum at PAAET. The study was guided by the following research questions:

1. How do pre-service science teachers perceive their current curriculum and the role of ICT in particular?

2. What are pre-service science teachers' attitudes toward and skills in using ICT at PAAET?

3. What are the needs of the pre-service science teachers at PAAET in relation to ICT in the program?

Answering these questions will provide insight into the feasibility of ICT integration in the curriculum of the science teacher preparation program of the PAAET in Kuwait, which will help to develop strategies for integrating ICT into the program.

\subsection{Methodology}

\subsubsection{Participants}

A total of 123 students from the science teacher preparation program at PAAET participated in the study. All of the participants were female and in their final semester of their final year in the program. Their average age was about 23 years. Most of the participants (96\%) owned a laptop or had a personal computer at home, and $92 \%$ indicated that they had access to an Internet connection. The participants in this study were students enrolled in the "Educational Seminar," a two-credit obligatory course. This course aims to train pre-service teachers to solve pedagogical problems they face during in-school training and teaching practices. The participants had science as their major $(75 \%, \mathrm{n}=92)$ or minor $(25 \%$, $\mathrm{n}=31$ ) specialization. Most of the respondents indicated that if they could start over again, they would apply to the same program they are now attending. Nearly all of the pre-service teachers (98\%) reported that they did not take the optional course, "Introduction to Computers," during their educational program. 


\subsubsection{Instruments}

\section{Science Education Program Profile Questionnaire}

The Science Education Program Profile Questionnaire was developed by the researcher, and addressed the first and third research questions. Using a 5-point Likert scale, this questionnaire contains statements about the science teacher preparation program that address the teaching strategy applied through the program, ICT integration in the program, attention for ICT integration in preservice prospective teaching practice, and pre-service ICT training needs. At the end of the questionnaire four short-answer questions were added to get more details about the situation throughout the program, such as "What do you think are the strengths and weaknesses of the program according to pedagogy, ICT, content, and practical work?", "What do you prefer in this program?", "In the case of planning an ICT training, what are your immediate needs from this training and why?" and finally, "What would you like to learn before graduation from the science teacher preparation program at PAAET and why?" A factor analysis was conducted, and three scales emerged, which were labelled "The status of ICT within the program", "Motivation for ICT integration", and "Training needs." Table 2.1 summarises the reliability of the scales.

Table 2.1 Scales, reliability and exemplary items of the program profile questionnaire

\begin{tabular}{|c|c|c|c|}
\hline Scale & \# Items & a & Examples of items \\
\hline $\begin{array}{l}\text { The status of ICT } \\
\text { within the } \\
\text { program }\end{array}$ & 4 & .90 & $\begin{array}{l}\text { - The program is preparing me with the } \\
\text { technological skills needed to design \& produce } \\
\text { my own educational digital media } \\
\text { - I think the program is preparing me to integrate } \\
\text { technology in my teaching practices after } \\
\text { graduation }\end{array}$ \\
\hline $\begin{array}{l}\text { Motivation for } \\
\text { ICT integration }\end{array}$ & 3 & .84 & $\begin{array}{l}\text { - I would like to integrate technology in my } \\
\text { teaching practice in the future } \\
\text { - I think that integrating technology in my } \\
\text { teaching will motivate my students to learn }\end{array}$ \\
\hline Training needs & 2 & .88 & $\begin{array}{l}\text { - I think that I need more training with } \\
\text { curriculum \& teaching strategies that integrate } \\
\text { technology } \\
\text { - I think that I need more training with } \\
\text { technology throughout the program }\end{array}$ \\
\hline
\end{tabular}

There were six questions that did not form a related construct, but they were considered vital from the perspective of the study. These included two questions 
about teaching strategies, and four questions about the pre-service teachers' perceptions about teaching with ICT. See Table 2.2 for the singular items that did not form a coherent scale.

Table 2.2 Singular items - Program Profile Questionnaire

\section{Singular items}

1. The teacher-centred approach is the only method used during the program.

2. We use a student-centred approach during the program.

3. During the program I am learning a lot of practical technology skills that I can use.

4. Teaching a lesson with technology will affect the pedagogy of the lesson.

5. I should rethink again about the science content while teaching with technology.

6. Designing a lesson using technology is a lot like designing a face-to-face lesson.

7. Designing a lesson using technology requires changes in how we teach and what we teach.

8. I think that the technological skills I learnt during the program are enough to help me to integrate technology in my teaching practices after graduation.

\section{Attitude toward ICT Questionnaire}

The Attitude toward ICT Questionnaire was adapted from the Teachers' Attitude toward Computers Questionnaire (TAC) (Christensen \& Knezek, 1996) to measure the attitude of the pre-service science teachers toward ICT. Six items were added to the TAC about the importance of ICT for learning. The adapted instrument was translated into the Arabic language and reviewed by two educational technology experts, to ensure that the items were fully understood by the pre-service teachers. A factor analysis was conducted from which three scales emerged, which were labelled "Instructional and productivity tool", "Enjoyment", and "Avoidance and frustration". Table 2.3 shows the reliability of each scale, with the number of items per scale, and exemplary items for each scale. 
Table 2.3 Reliability of the Attitude toward ICT questionnaire

\begin{tabular}{|c|c|c|c|}
\hline Scale & \# items & a & Examples of items \\
\hline $\begin{array}{l}\text { Instructional \& } \\
\text { productivity tool }\end{array}$ & 10 & .80 & $\begin{array}{l}\text { - If there is a computer in my future } \\
\text { classroom, it would help me to be a better } \\
\text { teacher* } \\
\text { - Computers are valuable tools that can be } \\
\text { used to improve the quality of education * }\end{array}$ \\
\hline Enjoyment & 9 & .85 & $\begin{array}{l}\text { - I enjoy lessons on the computer } \\
\text { - I enjoy doing things on a computer }\end{array}$ \\
\hline Anxiety \& frustration & 7 & .86 & $\begin{array}{l}\text { - Working with a computer makes me } \\
\text { nervous } \\
\text { - I will do as little work with computers as } \\
\text { possible }\end{array}$ \\
\hline
\end{tabular}

Note: *: added by the researcher.

\section{The ICT Skills Questionnaire}

The ICT Skills Questionnaire was created by combining two existing instruments: The national survey on information technology in teacher education by the Milken Exchange on Educational Technology (1999) and the Technology Proficiency Self-Assessment (TPSA) by Ropp (1999). The researcher added some items such as video conferencing, multimedia production, and simulations to assess more advanced ICT skills. This instrument was translated into Arabic and reviewed by two educational technology experts. The questionnaire has two main scales: 'things participants can do on a computer at school', and 'things participants feel confident to do on a computer'. A factor analysis was conducted from which two sub-scales emerged for each scale. For more details about the reliability of the subscales within each scale see Table 2.4 . 
Table 2.4 Reliability of ICT Skills Questionnaire

\begin{tabular}{|c|c|c|c|}
\hline Scale/subscale & \# items & a & Examples of items \\
\hline \multicolumn{4}{|c|}{ Things pre-service science teachers do on a computer at school: } \\
\hline - Basic skills & 7 & .82 & $\begin{array}{l}\text { - Word processing activities } \\
\text { - Creating presentations (PowerPoint etc.) }\end{array}$ \\
\hline - Advanced skills & 3 & .78 & $\begin{array}{l}\text { - Exploring environment or solving a problem } \\
\text { by using simulation programs. } \\
\text { - Joining video conferences to get/share } \\
\text { information about specific content with experts }\end{array}$ \\
\hline \multicolumn{4}{|c|}{ Things pre-service science teachers feel confident to do: } \\
\hline - Multimedia tools & 7 & .90 & $\begin{array}{l}\text { - Create 3D model for a specific structure or part* } \\
\text { - Edit video clips by video editing software }\end{array}$ \\
\hline - Email \& internet & 7 & .78 & $\begin{array}{l}\text { - Send a document as an attachment to an e- } \\
\text { mail message } \\
\text { - Search for and find the PAAET Web site }\end{array}$ \\
\hline
\end{tabular}

\subsection{Results}

Pre-service teachers' perception of the science teacher preparation program

Pre-service teachers' perceptions on their curriculum are presented in Table 2.5. The results revealed that $32.4 \%$ of the participants were satisfied with the way that ICT is addressed in their current program $(\mathrm{M}=2.75, \mathrm{SD}=0.99)$. The results also showed that $95.5 \%$ of the participants were motivated to integrate ICT in their teaching $(\mathrm{M}=4.5, \mathrm{SD}=0.59)$.

Table 2.5 Pre-service teachers' perception of their curriculum (M, SD and \%)

\begin{tabular}{|l|c|c|c|c|}
\hline Scale & N & Mean & SD & \%(strongly) agreed \\
\hline The status of ICT within the program & 111 & 2.75 & .999 & $32.4 \%$ \\
\hline Motivation for ICT integration & 111 & 4.51 & .591 & $95.5 \%$ \\
\hline
\end{tabular}

Note: $1=$ Strongly Disagree (SD); $2=$ Disagree (D), $3=$ Undecided (U), 4= Agree (A) \& 5= Strongly Agree (SA).

The answers of the singular questions are presented in Table 2.6. The majority of the participants believe that using ICT will affect the pedagogy of the lesson (item 4 ), and that lessons in which ICT is used require a change in what and how we teach (item 7). About half of the respondents stressed that only a teacher-centred approach is used during the program (item 1), and about the same number indicated that they experienced student-centred learning through the program 
(item 2). Further analysis showed that nearly all of the participants who had experienced the teacher-centred approach did not experience the student-centred approach. Also about half of the participants agreed that they were learning a lot of practical ICT skills that they can use (item 3). However, only a minority of the participants agreed that they should reconsider the content while using ICT (item 5), and think about whether designing a lesson using ICT is the same as designing a face-to-face lesson, and whether the ICT-skills they gain during the program are enough to integrate ICT in their future classroom (item 8). Considering the large values of the standard deviation for the previous questions, we conclude that the participants had different views and opinions in answering these questions.

Table 2.6 Pre-service teachers' perception of their curriculum - singular items ( $M, S D$ and \%)

\begin{tabular}{|c|c|c|c|c|}
\hline Items & $\mathbf{N}$ & Mean & SD & $\begin{array}{c}\% \text { (strongly) } \\
\text { agreed }\end{array}$ \\
\hline $\begin{array}{l}\text { 1. Teacher-centred approach is the only method } \\
\text { used at the program }\end{array}$ & 70 & 3.24 & 1.15 & $47.2 \%$ \\
\hline $\begin{array}{l}\text { 2. We use student-centred approach during the } \\
\text { program }\end{array}$ & 69 & 3.17 & 1.01 & $44.9 \%$ \\
\hline $\begin{array}{l}\text { 3. During the program I'm learning a lot of practical } \\
\text { technology skills that I can use }\end{array}$ & 109 & 3.06 & 1.24 & $44.9 \%$ \\
\hline $\begin{array}{l}\text { 4. Teaching a lesson with technology will affect the } \\
\text { pedagogy of the lesson }\end{array}$ & 112 & 4.01 & 1.14 & $78.6 \%$ \\
\hline $\begin{array}{l}\text { 5. I should rethink again about the (science) content } \\
\text { while teaching with technology }\end{array}$ & 112 & 4.11 & .780 & $32.8 \%$ \\
\hline $\begin{array}{l}\text { 6. Designing a lesson using technology is a lot like } \\
\text { designing face to face lesson. }\end{array}$ & 110 & 2.81 & 1.19 & $32.8 \%$ \\
\hline $\begin{array}{l}\text { 7. Designing a lesson using technology requires } \\
\text { changes in how we teach and what we teach }\end{array}$ & 110 & 3.74 & 1.00 & $69.1 \%$ \\
\hline $\begin{array}{l}\text { 8. I think that the technological skills I learnt during } \\
\text { the program are enough to help me to integrate } \\
\text { technology in my teaching practices after } \\
\text { graduation }\end{array}$ & 112 & 2.60 & 1.23 & $29.4 \%$ \\
\hline
\end{tabular}

The Program Profile questionnaire also included open-ended questions and a space for the participants to submit extra comments concerning the program. The first question was, "What do you think is the strength/weakness of the program according to pedagogy, ICT, content, and practical work ... etc.?" In relation to pedagogy, the respondents stated that they acquired an up-to-date theoretical 
overview of teaching methods and strategies during the pedagogical courses; however, these strategies were not practically applied during their program and they did not experience such a strategy themselves in the classes they took. The respondents also indicated that their program is mainly designed around lectures and memorizing facts.

Most of the respondents (85.3\%) indicated that they had a theoretical understanding of ICT and the role of ICT in education from the obligatory "Introduction to Educational Technology" course, but they did not use or experience the applications of ICT. In addition, $77 \%$ of the pre-service science teachers also indicated that the integration of ICT is rare within the whole program and depends on the skills, attitudes and beliefs of the individual instructor.

With regard to content knowledge in the program, all students agreed that the content is up to date. In relation to practical work, all pre-service science teachers indicated that the practical work (whether it is lab work and experimentations or field training) is very good and helpful for becoming professionals. However, $77 \%$ of the respondents indicated that the in-school training course introduced only in the last semester of the last year of the program comes too late to provide sufficient professional experience.

The final question of the Program Profile Questionnaire was about what the preservice teachers like to learn before graduating from the program and why. The answers to this question ranged from the need for training on time-management skills, dealing with students with special needs, dealing with school management, dealing with multitasks, and team-management skills.

\section{Pre-service teachers' attitude toward ICT}

Table 2.7 summarizes the results of the teachers' attitude toward ICT. The results show that nearly all of the participants (96.3\%) agreed that ICT-tools are valuable for instruction and they can improve teachers' productivity $(\mathrm{M}=4.25, \mathrm{SD}=$ $0.464)$. A majority of the respondents $(81 \%)$ believe that using ICT-tools makes learning more fun $(\mathrm{M}=3.94, \mathrm{SD}=0.655)$. Only a few respondents $(9.5 \%)$ indicated that using a computer frustrates them or makes them anxious $(\mathrm{M}=$ $2.43, \mathrm{SD}=0.845)$. About half of the respondent indicated that computers do not frustrate them, and $40 \%$ of the respondents had a neutral or undecided response regarding computer frustration. 
Table 2.7 Pre-service teachers' attitudes toward computers ( $M, S D \& \%)$

\begin{tabular}{|l|c|c|c|c|}
\hline Scale & N & Mean & SD & \% (strongly) agreed \\
\hline Instructional \& productivity tool & 108 & 4.25 & .464 & $96.3 \%$ \\
\hline Enjoyment & 107 & 3.94 & .655 & $81.3 \%$ \\
\hline Anxiety \& Frustration & 105 & 2.54 & .845 & $9.5 \%$ \\
\hline
\end{tabular}

Note: $1=$ Strongly Disagree (SD); $2=$ Disagree (D), $3=$ Undecided (U), $4=$ Agree (A) \& 5= Strongly Agree (SA).

Pre-service teachers' ICT skills

Table 2.8 Pre-service teachers' perception of their ICT skills (M, SD E \%)

\begin{tabular}{|c|c|c|c|c|}
\hline Scale/Subscale label & $\mathbf{N}$ & Mean & SD & $\begin{array}{c}\% \text { (strongly) } \\
\text { agreed }\end{array}$ \\
\hline \multicolumn{5}{|c|}{ Things pre-service science teachers do on a computer: } \\
\hline - Basic skills & 103 & 3.63 & .707 & $61.2 \%$ \\
\hline - Advanced skills & 106 & 2.87 & .929 & $22.6 \%$ \\
\hline \multicolumn{5}{|c|}{ Things pre-service science teachers feel confident to do: } \\
\hline - Multimedia tool & 103 & 3.04 & 1.041 & $32 \%$ \\
\hline - Email \& internet & 102 & 3.38 & .806 & $42.2 \%$ \\
\hline
\end{tabular}

Table 2.8 shows that $61.2 \%$ of the pre-service teachers were able to perform the basic skills on a computer, such as looking up information from CD-ROMs, exploring subject-specific software, word-processing activities, and surfing the web. However, only $22.6 \%$ of the pre-service teachers were able to perform the more advanced skills such as videoconferencing, working with simulations and animations, and visiting or experimenting with virtual labs or tours. Looking at the tasks that pre-service science teachers feel confident to carry out on a computer, about one third (32\%) of the respondents were confident in editing or producing multimedia products, such as editing pictures, sounds and videos, simulation, and creating 3D structures. Less than half of the pre-service teachers $(42.2 \%)$ were confident about carrying out tasks related to the Internet and email.

Pre-service teachers ICT needs in relation to the program

The results showed that nearly all of the pre-service teachers (91.9\%) expressed a need for more training in teaching strategies and methods that integrate ICT in science education $(\mathrm{M}=4.4, \mathrm{SD}=0.891)$. The pre-service teachers were also asked to address their program's immediate needs in relation to ICT, and the reasoning behind these needs. The answers to this question are summarized in Table 2.9. 
Table 2.9 Pre-service teachers' needs in relation to ICT training - the reasons for addressing this need $\mathcal{E}$ percentage of students

\begin{tabular}{|c|c|c|}
\hline ICT training needs & Why? & $\%$ \\
\hline PowerPoint (advanced level) & $\begin{array}{l}\text { To animate and rotate objects to imitate } \\
\text { scientific phenomena. }\end{array}$ & $83.7 \%$ \\
\hline Video Editing & $\begin{array}{l}\text { To edit video clips captured by the students or } \\
\text { the teacher. }\end{array}$ & $73.2 \%$ \\
\hline Adobe Photoshop & $\begin{array}{l}\text { To edit pictures and figures; add labels to } \\
\text { pictures, graphs, and figures. }\end{array}$ & $70.7 \%$ \\
\hline Adobe Illustrator & To create pictures and figures. & $40.7 \%$ \\
\hline Using multimedia in education & To enhance and speed up the learning process. & $36.6 \%$ \\
\hline $\begin{array}{l}\text { How to be an efficient web } \\
\text { searcher }\end{array}$ & $\begin{array}{l}\text { To reduce time and effort while searching the } \\
\text { Internet. } \\
\text { To validate gathered information. }\end{array}$ & $77.2 \%$ \\
\hline Spreadsheets and Tables & $\begin{array}{l}\text { As a requirement for the new curriculum } \\
\text { applied 2009-2010 }\end{array}$ & $40 \%$ \\
\hline Using ICT in & $\begin{array}{l}\text { To prepare pre-service teachers for the } 21^{\text {st }} \\
\text { century. }\end{array}$ & $70 \%$ \\
\hline Adobe Flash o & $\begin{array}{l}\text { To create digital stories and books, and } \\
\text { animate object. }\end{array}$ & $65 \%$ \\
\hline $\begin{array}{l}\text { How to deal with sounds (Sound } \\
\text { recording and editing skills.- } \\
\text { Inserting sound in to video clip- } \\
\text { Inserting sound in to power point } \\
\text { presentation). }\end{array}$ & $\begin{array}{l}\text { To enhance our presentations with sound } \\
\text { effects. }\end{array}$ & $80.5 \%$ \\
\hline $\begin{array}{l}\text { Designing and Creating web } \\
\text { pages }\end{array}$ & $\begin{array}{l}\text { To publish information or announcements } \\
\text { through the web. }\end{array}$ & $60.2 \%$ \\
\hline Database (e.g., Microsoft Access) & To organize data and information. & $30.1 \%$ \\
\hline $\begin{array}{l}\text { Digital Photography \& Digital } \\
\text { Camera }\end{array}$ & $\begin{array}{l}\text { To record and enhance the observation and the } \\
\text { experiments results }\end{array}$ & $60.2 \%$ \\
\hline $\begin{array}{l}\text { Learning any software that add } \\
\text { creativity to my teaching }\end{array}$ & To be creative in my teaching & $39.8 \%$ \\
\hline Developing an online test & To assess students learning and save time. & $20.3 \%$ \\
\hline $\begin{array}{l}\text { Evaluating educational software } \\
\text { or site }\end{array}$ & $\begin{array}{l}\text { To be able to choose good educational software } \\
\text { or educational site }\end{array}$ & $59.9 \%$ \\
\hline $\begin{array}{l}\text { Developing an online } \\
\text { environment for students or } \\
\text { group-work }\end{array}$ & $\begin{array}{l}\text { To share idea about classroom activities or } \\
\text { answer some questions. }\end{array}$ & $50.4 \%$ \\
\hline
\end{tabular}




\subsection{CONCLUSION AND DISCUSSION}

This study aimed to assess the perceptions of pre-service science teachers at PAAET regarding the current curriculum, especially in relation to ICT, their attitudes toward and skills of ICT use, and their ICT training needs.

\subsubsection{The current curriculum and the role of ICT in particular}

The results show that pre-service teachers were unsatisfied with how ICT was addressed in their program. Pre-service teachers were motivated to integrate ICT in their teaching practice after graduation. However, they stressed that they need more training on ICT because they think that the ICT skills they acquired during the program were not enough to help them integrate ICT in their future classroom. Most pre-service teachers agreed that teaching a lesson with ICT will not only affect how they teach (pedagogy), but also what they teach (content). In general, the findings indicate that the pre-service science teachers are motivated to learn more about the use of ICT for teaching and learning in their program. Pearson argued that teachers' preparation has focused too much on learning about ICT, but it is time to emphasise learning with ICT more in teacher education courses (cited in Kirschner \& Selinger, 2003).

\subsubsection{The attitudes and skills of the pre-service science teachers toward ICT}

A majority of the pre-service science teachers reported that they have a positive attitude toward ICT and they believe that ICT could be a tool for enhancing instruction and teacher productivity. Next to that, they stated that they enjoy working with ICT. Only a minority of the pre-service teachers indicated that they are anxious or feel frustrated while using ICT. Although most pre-service teachers did not take the introduction to computers course during their preparation program (see Section 2.4.1: Participants), most of the pre-service teachers are sufficiently computer literate; but only a few also possess advanced ICT skills or feel confident about using multimedia tools. The perception of the pre-service teachers about ICT as an instructional and productivity tool and about their basic ICT skills could be attributed to the following points. 1) Students' ICT experience in K-12: computer literacy was introduced as a new subject in schools starting in 2001. This confirms Teo, Lee, and Chai's (2008) findings that the perceived usefulness of computers in education was influenced 
by teachers' exposure to ICT prior to their joining teacher education. 2) Societal pressure and pressure from the government (ESCWA, 2007) to introduce ICT in different sectors of life. For example, in 2002 the Ministry of Education introduced incentives to encourage in-service/pre-service teachers in Kuwait to obtain the International Computer Driving Licence (ICDL) for job retention and promotion (ESCWA, 2003) and in 2008, the National IT Awareness Program were launched (ESCWA, 2009 b). 3) Adoption and ownership of ICT (e.g., computers, mobile phones, GPS...etc.) is considerably high in Kuwaiti society (ESCWA, 2003) and as Levine and Schmidt (1998) found, there is a high correlation between owning a computer with the motivation to use it, the perceived usefulness of computers, and technological knowledge.

\subsubsection{Pre-service science teachers' needs in relation to ICT}

Most pre-service teachers stressed that they need ICT training during their educational program. They confirmed that learning ICT skills during the program is not enough to help them integrate ICT into their teaching practice after graduation. They also indicated that they need extra training on practical ICT skills (mostly advanced skills), such as multimedia editing software and more advanced ICT skills, such as simulation and video conferencing. Most stated needs were rated very low in the ICT Skills Questionnaire. What was interesting was that the pre-service teachers were able to address the pedagogical uses of ICT for the stated needs.

In conclusion, the pre-service science teachers at PAAET reported that they have a positive attitude toward ICT, that they have basic ICT skills and that they are aware of ICT and its potential role in education, but they are not sure about their ability to integrate ICT into their teaching. This means that they do not consider themselves to be ICT-integrating teachers. This is consistent with Alhammar's (2006) research, reporting deficiencies in Kuwaiti higher education. The lack of preparation to be ICT-integrating teachers can be attributed to the following reasons: 1) the ICT-focused courses do not provide students with the ability to integrate ICT in practice (Adamy \& Boulmetis, 2006; Brown \& Warschauer, 2006; Keeler, 2008), 2) there is limited ICT integration throughout the program, so the pre-service teachers do not experience authentic use of ICT in teaching and learning (e.g., Doering, Hughes \& Huffman, 2003; Kay; 2007; Milbrath \& Kinzie, 2000), and 3) traditional teaching methods. 
However, pre-service teachers need ICT-related skills or ICT-enhanced method courses that emphasise pedagogical uses of ICT in practice to be infused into the curriculum (Coppola, 2004; Hasselbring et al., 2000). This in turn will help in the development of the knowledge needed for effective use of ICT in future practices (Angeli \& Valanides, 2005; Mishra \& Koehler, 2006; Margerum-Lays \& Marx, 2003). Moreover, moving toward a more student-centred approach with authentic experience will help prepare pre-service teachers for ICT integration.

The results of this study have shed light on promising directions for the integration of ICT in the science teacher preparation program at PAAET. Several other researchers have suggested strategies to help pre-service teachers to better understand and experience the role ICT in education. This could be achieved by 1) helping pre-service teachers understand how student-centred practices, supported by ICT, impact students' learning (Ertmer \& Ottenbreit-Leftwich, 2010; Kanaya, Light, \& Culp, 2005); 2) providing pre-service teachers with concrete examples of what teaching with ICT looks like in practice and what will facilitate change in teachers' knowledge and beliefs about ICT (Zhao \& Cizko, $2001)$; 3) providing pre-service teachers with opportunities to explore and experiments with the pedagogical uses of ICT tools will help pre-service teachers to become more confident about integration (Ertmer \& Ottenbreit-Leftwich, 2010); and 4) working in an authentic, collaborative learning environment could be a suitable strategy to help pre-service teachers to integrate ICT in their future practices or to predict ICT use in their classrooms (Kay, 2007). Follow-up research is needed in the pre-service science teacher preparation program at PAAET that will focus on providing pre-service teachers with experience, knowledge, and skills to become ICT-integrating teachers. 


\title{
CHAPTER 3
}

\section{ICT integration through Design Teams in science teacher preparation*}

\begin{abstract}
In this study, the Technological Pedagogical Content Knowledge (TPACK) framework is used to prepare students in the science teacher preparation program at the Public Authority of Applied Education and Training in Kuwait. Students worked in small Design Teams and were coached by technology, pedagogy, and content experts, to find a technological solution for a pedagogical problem that a teacher normally faces. In Design Teams, students blended content, pedagogy, and Information and Communication Technology (ICT) to design a learning environment enhanced with ICT. Data was collected on students' attitudes towards ICT and teamwork, their ICT skills, and their perception of their TPACK development. Pre-service teachers' need for support and the criteria for that support were assessed. The findings indicated that students gained higher results in TPACK and ICT skills, and had a positive attitude toward ICT and toward working in Design Teams.
\end{abstract}

\subsection{INTRODUCTION}

The teacher preparation program at the Public Authority of Applied Education \& Training (PAAET) in Kuwait, and especially the science teacher preparation program, is focused on technological skills as stand-alone courses, with the assumption that providing students with technological skills will automatically lead to the effective integration of Information and Communication Technology (ICT) in their future classrooms. But this is not the case. For instance, Alhammar (2006) found that pre-service teachers in the Gulf region, especially in Kuwait, were unable to use ICT effectively in their profession. The literature shows that teachers need to experience and practice ICT-integration throughout their

Alayyar, G., Fisser, P., \& Voogt, J. (accepted). ICT Integration through Design Teams in science teacher preparation. International Journal of Learning Technology (special issue). 
undergraduate programs to become ICT-integrating teachers (Koehler \& Mishra 2008; Koehler, Mishra, Hershey \& Peruski 2004). Koehler and Mishra (2005) emphasized that teacher education programs need to develop students' Technological Pedagogical Content Knowledge (TPACK) to enable them to use ICT successfully in their daily practices after graduation.

One strategy to develop TPACK is through working in Design Teams (DTs) (e.g., Koehler, Mishra \& Yahya 2007). The current study aims to identify preservice science teachers' development of TPACK through DTs.

\subsection{THEORETICAL FRAMEWORK}

\section{Effective ICT integration through TPACK}

Hughes (2004) argued that ICT-integrating teachers are able to "understand, consider, and choose to use technologies, when they uniquely enhance curriculum, instruction, and/or students' learning in a subject matter area" (Hughes 2004, p. 346). According to Zhao (2003), teachers' knowledge of ICT must consist of three elements: a) knowledge of problems or situations that can be solved with ICT, b) knowledge of what kind of ICT can solve this kind of problem and c) knowledge of how this ICT can solve the specified problem. This kind of knowledge is also known as Technological Pedagogical Content Knowledge (TPACK) (Koehler et al. 2004; Mishra \& Koehler 2006).

TPACK (Figure 3.1) provides a conceptual framework to describe the knowledge a teacher needs for effective ICT integration in education (Hughes 2004; Keating \& Evans 2001; Koehler \& Mishra 2005; Mishra \& Koehler 2006; Niess 2005). It stems from Shulman's concept of Pedagogical Content Knowledge (PCK) by the inclusion of technological knowledge (TK). The TPACK framework argues that for pedagogical use of ICT, teachers are required to integrate their knowledge of content, pedagogy, and ICT. According to the TPACK framework, effective teaching with ICT requires a "dynamic equilibrium" between content, pedagogy, and ICT, such that a change in any of the three domains will change the other two (Koehler \& Mishra 2008).

Niess (2005) clarified that for ICT to become an integral component or tool for learning science, science teachers must develop a conception of their subject matter with respect to ICT and what it means to teach with ICT. Webb and Cox 
(2004) argued that ICT integration in science education is associated with a fundamental change in the learning process, by which the teaching process evolves from an emphasis on teacher-centred instruction to more student-centred learning environments. McCrory (2008) addressed four elements of TPACK in science education: a) knowledge of science; b) knowledge of students' perceptions; c) knowledge of science-specific pedagogy; and d) knowledge of ICT. This requires teachers to know which part of the science curriculum is difficult for students, how ICT can be used to resolve these difficulties, and for which science topic ICT is considered essential (Voogt, Tilya, \& Akker 2009).

The knowledge domains related to TPACK (Figure 3.1) include Content Knowledge (CK), knowledge about the subject matter (e.g., Science), Pedagogical Knowledge (PK), knowledge about educational processes, teaching strategies and teaching methods, and Technological Knowledge (TK), knowledge about ICT affordances and constraints, and ICT skills. The intersection between the knowledge domains produces Pedagogical Content Knowledge (PCK), which is the knowledge to teach specific content (Shulman 1987). This is the ability to make content understandable and meaningful for students, while taking into account students' styles, misconceptions, and prior knowledge. Technological Pedagogical Knowledge (TPK) is knowledge about how to use ICT to teach certain contents and the understanding of how teaching and learning can be changed through the use of ICT. Technological Content Knowledge (TCK) encompasses knowledge about how ICT and content are related. Teachers need to know how subject matter can be transformed by using ICT.

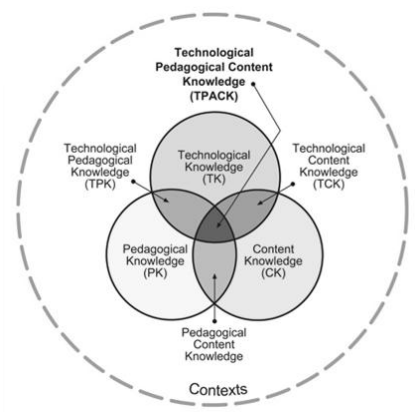

Figure 3.1 The TPACK framework (adopted from Koehler \& Mishra, 2008)

The overlapping and interactions of all of the different knowledge domains will produce Technological Pedagogical Content Knowledge (TPACK), which is the central part of the model. It reflects the understanding of representing certain concepts using suitable ICT and pedagogy in a constructive way (Koehler \& 
Mishra 2009). Besides understanding and developing knowledge related to TPACK, it is important for teachers to understand the "Context" in which ICT will be integrated (Harris, Mishra \& Koehler 2009). According to Mishra and Koehler (2006), any ICT integration is unique, because it is the result of an interweaving of TK, PK, CK and the context in which they function. This means that there is no single ICT solution that will fit perfectly in all courses or learning environments, because ICT integration is context-sensitive and situation-specific.

\section{Learning ICT by design and Design Teams}

Researchers concerned with the development of TPACK use authentic designbased activities (Angeli \& Valanides 2005; Koehler \& Mishra 2005; Koehler, Mishra, \& Yahya 2007). Koehler and Mishra (2005) used the Learning Technology by Design approach, by which teachers work collaboratively to design an ICT-related solution for an authentic problem. They found that preservice teachers who engaged in Learning Technology by Design initially saw TK, PK, and CK as separate entities, but moved toward a more integrated and inter-related perception of TK, PK and CK.

Koehler, Mishra, and Yahya (2007) proposed that teachers should work collaboratively in Design Teams (DTs) to develop TPACK by designing an ICT solution for a pedagogical problem. DT is a group working together to produce a unit of instruction (Waddoups, Nancy, \& Earle 2004). Handelzalts (2009) defines a DT as a group of teachers who share a common goal, actively negotiate this goal, and try to arrive at a solution. One of the main ideas behind the concept of DT is that it provides a creative space for a group of teachers to plan, design, and work together for the benefit of their subject and their own professional development (Simmie 2007). DTs can be organized in different compositions, for different tasks, and with different kinds of support (Mishra, Koehler \& Zhao 2007). Through collaboration within a DT, the motivation and commitment of the participating teachers increase toward intervention (Day, Elliot \& Kington 2005). DTs contribute to a better sense of efficacy of the teachers toward their practices (Handelzalts 2009; Mishra et al. 2007). They give teachers emotional and moral support (Kruse \& Louis 1997), increase communication among the teachers (Kruse \& Louis 1997), and contribute to building a culture of collaboration and deliberation (Marsh 1994).

In this study, a DT is defined as a group of pre-service teachers who work collaboratively to design and develop ICT solutions for an authentic problem 
they face during their in-school training (adopted from Mishra \& Koehler 2003). It is expected that by forming DTs to design an ICT solution, teachers will learn different ICT skills during the design process, and will start thinking about ICT as a tool for achieving instructional objectives, rather than considering ICT as an end in itself. This requires more critical thinking about the purposes of ICT and the goals of instruction. It is expected that by working in DTs, teachers will be active learners; through collaboration with different team members, they will learn by doing and experimenting with different kinds of ICT-tools to solve the pedagogical problems they encounter. Each member of the team will teach the other members and at the same time learn from them.

TPACK and attitude and skills related to ICT

The main aim of any TPACK-related intervention is the preparation of teachers to integrate ICT effectively in their daily practice (i.e., become ICT-integrating teachers). This means that gaining or developing TPACK will lead to a growth in ICT-related skills.

Researchers have stressed that attitude toward ICT is one of the most important factors that affect the successful use of computers in the classroom (Huang \& Liaw 2005; Zhao, Tan, \& Mishra 2001). Bullock (2004) found that teachers' attitude is a major enabling/disabling factor in the adoption of ICT. Similarly, Kersaint, Horton, Stohl, and Garofalo (2003) found that teachers who have a positive attitude toward ICT feel more comfortable with using ICT and incorporate ICT into their teaching. Moreover, teachers' positive attitude toward ICT is important for avoiding their resistance to computer use in the classroom (Watson 1998 b). Thus, it can be assumed that teachers' skills and attitudes in relation to ICT are important factors for integrating ICT in educational practice.

\subsection{CONTEXT OF THE STUDY}

The science teacher preparation program at PAAET is a four-year tertiary program that aims to prepare science teachers for the primary level. Only female students are accepted to join this program, since almost all primary public schools in the State of Kuwait have female staff. This section focuses on two issues within the program that are of major importance to this research: the status of ICT integration in education and the teaching methods that students experience throughout the program. 
The science teacher preparation program at PAAET offers a two-credit optional course on computer literacy in which students learn basic computer skills. Next to this, two compulsory courses are offered, a theoretical course about educational technology and a course related to traditional technology, such as transparencies and posters. Hence, students do not have enough opportunities to learn about the full range of ICT, and how to incorporate ICT into their own teaching. The program's instructors use traditional tools for teaching, and hardly use ICT in their courses. In general, instructors only use ICT to enter grades into the grading system, print hand-outs and course syllabi, and sometimes to create PowerPoint presentations.

Our preliminary study (Alayyar, Fisser \& Voogt, submitted a) indicated that the pre-service science teachers at PAAET had a positive attitude towards ICT, they had basic ICT skills, and were aware of the importance of ICT for science education. However, they were not sure about their ability to integrate ICT into their practices.

\subsection{INTERVENTION}

The course designed in the frame of this study was part of the last semester of the fourth year of the PAAET science teacher preparation program and was organized in the form of Design Teams (DTs). The main task for the DTs was to choose or identify one topic to be taught with ICT, to identify a way to transform the content by using ICT, to determine teaching strategies to use ICT with a learner-centred focus, and to select a suitable ICT tool for teaching the topic, taking into account the affordances and constraints of the ICT tools. At the end of the course, the teams were asked to present their solution to their peers and to submit their product, their lesson plan, and their ICT integration plan.

The DTs consisted of three to four pre-service students, and each team member was responsible for a specific task in the team: a team leader, a pedagogical specialist, a technology specialist, and a content specialist. During the whole semester, students were coached by a pedagogical expert, a technology expert, and a content expert, who also evaluated the final product. The intervention took place during the autumn semester of the academic year 2009-2010. The experiment lasted 12 weeks, two hours per week. Table 3.1 shows an overview of different activities throughout the course. 


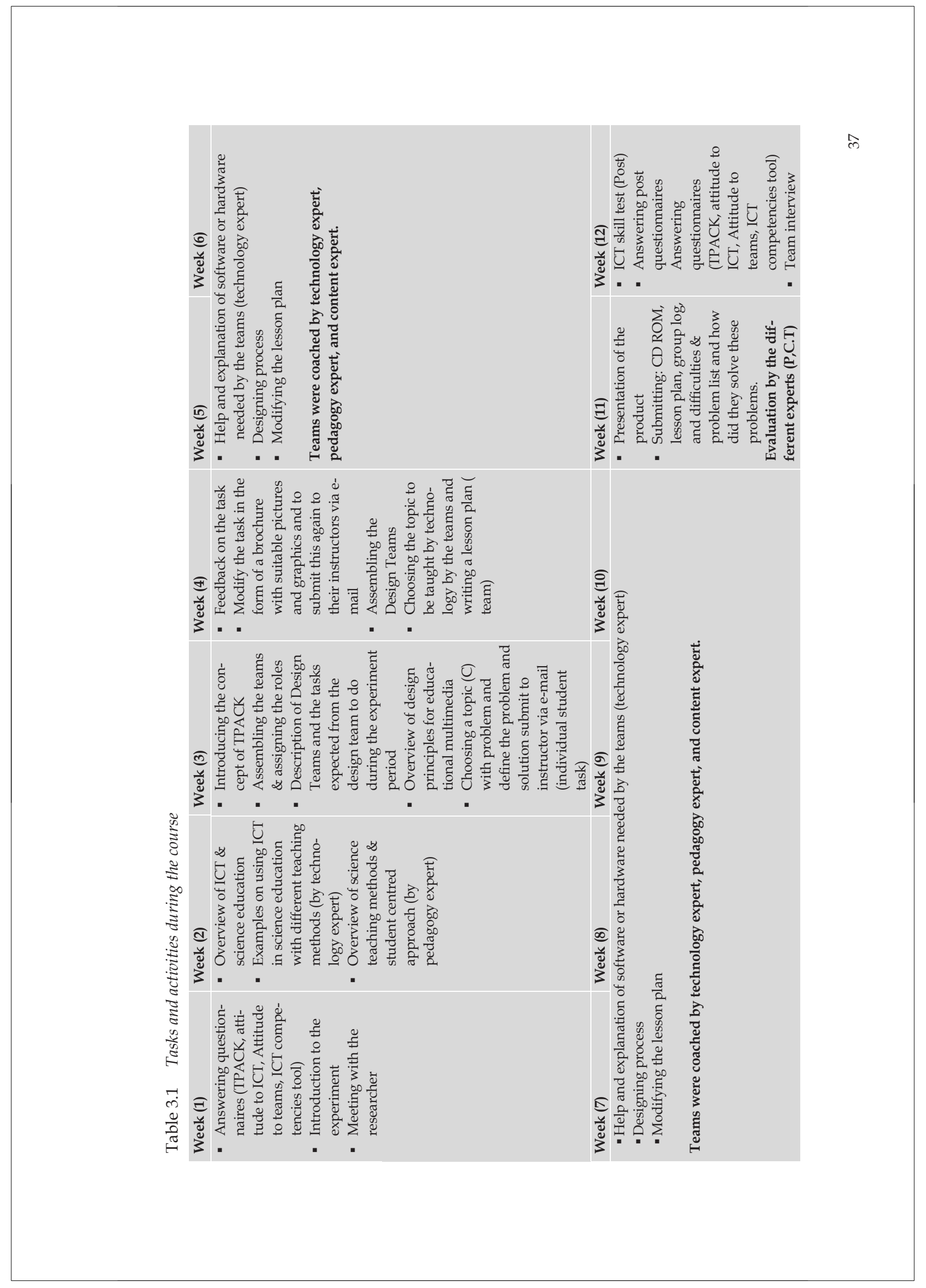




\subsection{PROBlem STATEMENT AND RESEARCH QUESTIONS}

The current study aims to provide pre-service science teachers at PAAET with the skills and knowledge required for an ICT-integrating teacher. This paper aims to answer the following research question:

Was there a change in the TPACK, ICT skills, and attitudes toward ICT of the pre-service science teachers who participated in DTs?

Four sub-research questions were derived from the main research question, as follows:

RQ1: Was there a change in the TPACK of the pre-service teachers as a result of working in DTs?

RQ2: Was there a change in the ICT skills of the pre-service teachers change as a result of working in DTs?

RQ3: Did the attitude of the pre-service teachers toward ICT change as a result of working in DTs?

RQ4: How do the pre-service teachers experience working in DTs and what do they need while working in DTs?

\subsection{Methodology}

\subsubsection{Participants}

The participants in the study included 61 students from the science teacher preparation programme at PAAET. All of the students were female and in the final semester of their final year. Their average age was 23 years. The participants either had science as their major or minor specialisation. Of the total participants, $98 \%$ had a computer at home and $94 \%$ indicated that they had an Internet connection at home.

\subsubsection{Instruments}

For the purpose of this study, six instruments were used. Table 3.2 shows how the different instruments are related to the research sub-questions. 
Table 3.2 List of instruments and related questions

\begin{tabular}{|l|c|c|c|c|}
\hline & $\begin{array}{c}\text { Changes in } \\
\text { TPACK }\end{array}$ & $\begin{array}{c}\text { Changes in } \\
\text { ICT skill }\end{array}$ & $\begin{array}{c}\text { Changes in } \\
\text { attitude to } \\
\text { ICT }\end{array}$ & $\begin{array}{c}\text { Working in } \\
\text { DT }\end{array}$ \\
\hline TPACK survey & $X$ & & & \\
\hline ICT skills & & $X$ & & \\
\hline Attitude toward ICT & & & $X$ & $X$ \\
\hline Attitude toward DT & & & & $X$ \\
\hline TPACK interview & $X$ & & $X$ \\
\hline Logbooks & & & & \\
\hline
\end{tabular}

\section{The TPACK survey}

The TPACK survey (Schmidt et al. 2009) was used at the start and the end of the intervention to assess the development of TPACK. The TPACK survey was translated into Arabic and reviewed by two educational technology experts. Table 3.3 provides a summary of the different knowledge domains, the number of items within each construct, exemplary items for each construct, and Cronbach's alpha for each construct.

Table 3.3 Description of the TPACK survey (different construct, number of items in each construct, exemplary items, E Cronbach's alpha)

\begin{tabular}{|c|c|c|c|}
\hline Construct & \# items & Exemplary items & $\mathbf{\alpha}$ \\
\hline TK & 7 & $\begin{array}{l}\text { - I know how to solve my own technical problems } \\
\text { - I know about a lot of different technologies. }\end{array}$ & .947 \\
\hline CK & 3 & $\begin{array}{l}\text { - I can use a scientific way of thinking. } \\
\text { - I have sufficient knowledge about science. }\end{array}$ & .881 \\
\hline PK & 7 & $\begin{array}{l}\text { - I know how to assess student performance in a } \\
\text { classroom. } \\
\text { - I can adapt my teaching style to different learners. }\end{array}$ & .959 \\
\hline PCK & 1 & $\begin{array}{l}\text { - I know how to select effective teaching approaches to } \\
\text { guide student thinking and learning in science. }\end{array}$ & - \\
\hline TCK & 1 & $\begin{array}{l}\text { - I know about technologies that I can use for } \\
\text { understanding and doing science }\end{array}$ & - \\
\hline TPK & 5 & $\begin{array}{l}\text { - I can choose technologies that enhance the teaching } \\
\text { approaches for a lesson. } \\
\text { - I am thinking critically about how to use technology in } \\
\text { my classroom. }\end{array}$ & .936 \\
\hline TPACK & 5 & $\begin{array}{l}\text { - I can choose technologies that enhance the content for } \\
\text { a lesson. } \\
\text { - I can teach lessons that appropriately combine science, } \\
\text { technologies, and teaching approaches. }\end{array}$ & .951 \\
\hline
\end{tabular}




\section{ICT skills tools}

This instrument consists of two parts, the ICT skills test and the ICT skills questionnaire. The ICT skills test is a performance attainment instrument to measure specific technological skills of the students at the start and at the end of the intervention. This test was designed by the researcher, and consists of six questions, to measure different skills such as dealing with the operating system, proficiency with the Microsoft office suite, the Internet, Adobe Photoshop, and multimedia editing software. The test was reviewed by an educational technology expert. The reliability of this test was 0.83 , as shown in Table 3.4. The ICT skills questionnaire is a self-report measure and was created by combining two existing instruments (the national survey on information technology in teacher education by the Milken Exchange on Educational Technology (1999) and the Technology Proficiency Self-Assessment (TPSA) by Ropp (1999). Some items were added by the researcher, to assess additional ICT skills such as video conferencing, multimedia production, and simulation. The questionnaire assesses the students' level of ICT skills before and after the intervention. The statements in this questionnaire are categorized into two groups addressing the things that respondents do on a computer at school, and the things that they feel confident to do. This instrument was translated into Arabic and reviewed by two educational technology experts. A factor analysis was conducted, from which two factors emerged for each group. Table 3.4 shows a summary of the different scales with each group, the number of items within each scale, exemplary items related to different scales, and Cronbach's alpha for each scale as calculated from gathered data during this study. 
Table 3.4 Description of the ICT skill tool (different construct, number of items in each construct, exemplary items, \& Cronbach's alpha)

\begin{tabular}{|c|c|c|c|}
\hline Scale & \# items & Exemplary items & a \\
\hline ICT skill test & 13 & $\begin{array}{l}\text { - How to create a new folder? } \\
\text { - State the type of each file (A.avi- B.doc- C.wav- } \\
\text { D.jpeg) }\end{array}$ & .83 \\
\hline $\begin{array}{l}\text { ICT } \\
\text { questionnaire }\end{array}$ & 24 & $\begin{array}{l}\text { - Animate object to explain a phenomena or } \\
\text { process. } \\
\text { - Send a document as an attachment to an e-mail } \\
\text { message. }\end{array}$ & .97 \\
\hline \multicolumn{4}{|c|}{ Things pre-service science teachers do on a computer at school } \\
\hline Basic skills & 7 & $\begin{array}{l}\text { - Word processing activities } \\
\text { - Creating presentations (PowerPoint etc.) }\end{array}$ & .91 \\
\hline $\begin{array}{l}\text { Advanced } \\
\text { skills }\end{array}$ & 3 & $\begin{array}{l}\text { - Exploring environment or solving a problem by } \\
\text { using simulation programs. } \\
\text { - Joining video conferences to get/share } \\
\text { information about specific content with experts }\end{array}$ & .86 \\
\hline \multicolumn{4}{|c|}{ Things pre-service science teachers feel confident to do } \\
\hline $\begin{array}{l}\text { Multimedia } \\
\text { tools }\end{array}$ & 7 & $\begin{array}{l}\text { - Create 3D model for a specific structure or part. * } \\
\text { - Edit video clips by video editing software. }\end{array}$ & .94 \\
\hline $\begin{array}{l}\text { Email \& } \\
\text { internet }\end{array}$ & 7 & $\begin{array}{l}\text { - Send a document as an attachment to an e-mail } \\
\text { message. } \\
\text { - Search for and find the PAAET Web site }\end{array}$ & .91 \\
\hline
\end{tabular}

\section{Attitude toward the ICT questionnaire}

The Attitude toward the ICT questionnaire was based on the Teachers' Attitude toward Computers Questionnaire (TAC) (Christensen \& Knezek 1996). Eight items were added to the questionnaire about the "the importance of ICT for learning processes" and "technical problems while working with computers." The questionnaire was translated into Arabic and was reviewed by two educational technology experts. A factor analysis was conducted, from which three factors emerged.: "Instructional \& productivity tool", "Enjoyment", and "Anxiety \& Frustration." Table 3.5 shows a summary of the different scales, the number of items within each scale, examples of items related to different scales, and Cronbach's alpha for each scale. The attitude of students toward ICT was measured at the beginning and at the end of the intervention. 
Table 3.5 Description of the attitude toward ICT questionnaire (different construct, number of items in each construct, exemplary items, \& Cronbach's alpha)

\begin{tabular}{|c|c|c|c|}
\hline Scale & \# items & Exemplary items & a \\
\hline $\begin{array}{l}\text { Instructional \& } \\
\text { productivity tool }\end{array}$ & 10 & $\begin{array}{l}\text { - I believe textbooks will be replaced by electronic } \\
\text { media. * } \\
\text { - Computers are valuable tools that can be used to } \\
\text { improve the quality of education. * }\end{array}$ & .91 \\
\hline Enjoyment & 9 & $\begin{array}{l}\text { - I enjoy lessons on the computer } \\
\text { - I enjoy doing things on a computer }\end{array}$ & .90 \\
\hline $\begin{array}{l}\text { Anxiety } \mathcal{E} \\
\text { frustration }\end{array}$ & 7 & $\begin{array}{l}\text { - Working with a computer makes me nervous } \\
\text { I get a sinking feeling when I think of trying to use a } \\
\text { computer. }\end{array}$ & .87 \\
\hline
\end{tabular}

Note: *: added by the researcher.

\section{Attitude toward the Teamwork questionnaire}

The Attitude toward the Teamwork questionnaire was developed by the researcher. This questionnaire consists of 12 items and uses a 5-point Likert scale to rate the extent to which students agree or disagree with statements concerning teamwork. The questionnaire was reviewed by two different educational technology experts. A factor analysis was conducted, from which three different factors emerged. "appreciation of teamwork", "leadership and understanding of others", and "avoidance." Table 3.6 provides a summary of the different scales, the number of items within each scale, examples of items related to different scales, and Cronbach's alpha for each scale in this study.

Table 3.6 Description of the attitude toward teamwork questionnaire (different scale, number of items in each scale, exemplary items, E Cronbach's alpha)

\begin{tabular}{|c|c|c|c|c|}
\hline Scale & \# items & Exemplary items & $\alpha$ & a \\
\hline Appreciation & 6 & $\begin{array}{l}\text { - Group/team decision-making is important to } \\
\text { societies and organizations. } \\
\text { - I think team work will fit well in my future } \\
\text { classroom. }\end{array}$ & .84 & .95 \\
\hline $\begin{array}{l}\text { Leadership \& } \\
\text { understanding } \\
\text { others }\end{array}$ & 3 & $\begin{array}{l}\text { I am comfortable in leadership roles. } \\
\text { - I am good at reading other people. }\end{array}$ & .60 & .89 \\
\hline Avoidance & 3 & $\begin{array}{l}\text { - I prefer to work alone rather than in teams. } \\
\text { - I dislike being evaluated based on team work. }\end{array}$ & .76 & .77 \\
\hline
\end{tabular}




\section{The TPACK interview}

A semi-structured interview was designed to assess individual student opinions about two main topics: TPACK understanding and experience, and the support and help a DT needs during the design process (RQ2). This interview consisted of the following questions:

1. What is TPACK?

2. Describe a situation where you effectively combined the content you teach with ICT and a specific teaching approach in a classroom lesson. Please include in your description the content you taught, what ICT you used, and what teaching approaches you implemented.

3. Are you interested in what you have learned in this course? Are you willing to apply this in your future practices? Or have you already tried it out during your in-school field training?

4. What kind of support or help do you need during the design process or while working in a design team?

5. What are the criteria of the support system?

Table 3.7 shows the TPACK reflection rubric that was developed by the researcher to analyse the data related to the first two interview questions.

Table 3.7 The TPACK reflection rubric

\begin{tabular}{l|l|l|l|l|} 
Points & $\mathbf{3}$ & $\mathbf{2}$ & $\mathbf{1}$ & $\mathbf{0}$ \\
\hline $\begin{array}{l}\text { Definition Of } \\
\text { TPACK }\end{array}$ & $\begin{array}{l}\text { PK, TK, CK interact } \\
\text { and intertwined } \\
\text { (PCK,TPK, TCK \& }\end{array}$ & $\begin{array}{l}\text { PK, TK, CK } \\
\text { interact and } \\
\text { intertwined } \\
\text { sPACK) together in } \\
\text { state of equilibrium } \\
\text { within the context }\end{array}$ & $\begin{array}{l}\text { PK, TK, } \\
\text { CK inter- } \\
\text { act with } \\
\text { each } \\
\text { other }\end{array}$ & $\begin{array}{l}\text { PK (or no } \\
\text { explanation } \\
\text { at all) }\end{array}$ \\
& & & \\
& & &
\end{tabular}

Teams logs

At the end of the intervention, the DTs were asked to submit a logbook in which they described the problems they faced during the design process, how they solved these problems, from whom they got support and assistance, and the different activities that occur within the DT during the design process. 


\subsubsection{Data analysis}

Means and standard deviations were calculated for the scales in the TPACK survey, the ICT skills survey, and the two attitude questionnaires. To compare the difference between pre- and post-measures, the t-test was used. If the result of the $t$-test was significant, then the effect size (Cohen's d) was calculated to get an indication of the magnitude of the effect. Cohen (1988) provided tentative benchmarks for the interpretation of effect sizes. He considers $\mathrm{d}=0.2$ a small, $\mathrm{d}=0.5$ a medium, and $\mathrm{d}=0.8$ a large effect size .

The interview data were analysed by using the TPACK interview rubric (Table 3.7). The logbooks were analysed by grouping the ICT needs or problems into different groups in relation to TPACK; then items related to TK were subgrouped according to their functions such as photo-editing, video-editing, presentation, sound-editing, animation, tables, and database.

\subsection{RESULTS}

\subsubsection{Change in TPACK}

Pre-service teachers' perceptions on their TPACK are presented in Table 3.8. The results at the beginning of the intervention showed that PK and CK achieved the highest mean score of 3.69 each out of a possible 5, because PK and CK were addressed during the program. PCK, TCK, and TK achieved a mean score of 3.59, 3.21, and 3.19, respectively. The score of PCK could be due to the fact that our context only experienced actual teaching during the in-school field training during the final semester of their educational program (i.e., the same semester in which the data were collected). From the literature, we know that an increase of PCK is mainly influenced by real teaching experiences (Van Driel, De Jong, \& Verloop 2002). For TCK, students felt some confidence, which may be due to the reciprocal relationship between science and ICT (e.g., Flick \& Bell 2000). However, TPACK and TPK were rated the lowest with mean scores of 2.96 and 2.88, respectively. This may be because this was the first time that the students were confronted with this type of knowledge. 
At the end of the intervention, the results showed that the participants scored higher in all domains related to TPACK. An increase in TK $(\mathrm{t}=-2.74, \mathrm{df}=52$, $\mathrm{p}=0.008)$, PK $(\mathrm{t}=-2.08, \mathrm{df}=50, \mathrm{p}=0.043)$, and PCK $(\mathrm{t}=-2.86, \mathrm{df}=52$, $\mathrm{p}=0.006)$ were found with a medium effect size $(\mathrm{d}=0.54, \mathrm{~d}=0.47$, and $\mathrm{d}=0.56$, respectively). Moreover, the TPK $(\mathrm{t}=-6.94, \mathrm{df}=52, \mathrm{p}=0.0001)$ and TPACK $(\mathrm{t}=-7.00, \mathrm{df}=52, \mathrm{p}=0.0001)$ also increased with a large effect size $(\mathrm{d}=1.3$ and $\mathrm{d}=1.4$, respectively). For TCK $(\mathrm{t}=-3.95, \mathrm{df}=52, \mathrm{p}=0.0001)$, there was significant increase at the end of the intervention with a large effect size $(\mathrm{d}=0.78)$; however, the participants had different opinions $(\mathrm{SD}=1.01)$. The increase in $\mathrm{CK}(\mathrm{t}=-.64, \mathrm{df}=52, \mathrm{p}=0.524)$ was not significant.

Table 3.8 A comparison of the pre-service teachers' perception of their TPACK

\begin{tabular}{|l|c|c|c|c|}
\hline Constructs & $\begin{array}{c}\text { Pre } \\
\text { Mean }(S D)\end{array}$ & $\begin{array}{c}\text { Post } \\
\text { Mean (SD) }\end{array}$ & $\begin{array}{c}\text { P } \\
\text { (level of significance) }\end{array}$ & Effect size \\
\hline TK & $3.19(.668)$ & $3.63(.937)$ & .008 & .54 \\
\hline CK & $3.69(1.17)$ & $3.85(.858)$ & .524 &.- \\
\hline PK & $3.69(.511)$ & $4.01(.822)$ & .043 & .47 \\
\hline PCK & $3.59(.795)$ & $4.07(.929)$ & .006 & .56 \\
\hline TCK & $3.21(.885)$ & $3.95(1.01)$ & .0001 & .78 \\
\hline TPK & $2.88(.640)$ & $3.88(.883)$ & .0001 & 1.3 \\
\hline TPACK & $2.96(.551)$ & $3.95(.865)$ & .0001 & 1.4 \\
\hline
\end{tabular}

Note: $1=$ Strongly Disagree (SD); $2=$ Disagree (D), 3= Undecided (U), 4= Agree (A) \& 5= Strongly Agree (SA).

The results of the students' answers to the interview questions revealed that about $78 \%$ of the students were able to define TPACK (Mean $=87.1, \mathrm{SD}=14.24$ ) and $72 \%$ were able to describe an effective example of how to teach content with suitable ICT and teaching strategy (Mean $=83.5, \mathrm{SD}=9.48$ ). Table 3.9 summarizes the students' answers to the first two interview questions.

Table 3.9 Pre-service teachers' answers to TPACK interview part (1) (M, SD \& \%)

\begin{tabular}{|c|c|c|c|c|c|c|c|}
\hline & Mean (SD) & $\begin{array}{l}\geq \\
90\end{array}$ & $\begin{array}{l}89- \\
80\end{array}$ & $\begin{array}{l}79- \\
70\end{array}$ & $\begin{array}{l}69- \\
60\end{array}$ & $<60$ & $\begin{array}{c}\quad \# \\
\text { students }\end{array}$ \\
\hline TPACK definition & 87.1 (14.24) & 19 & 12 & - & 7 & 2 & 40 \\
\hline \multicolumn{2}{|c|}{$\begin{array}{l}\text { Percentage of students that score } 80 \% \text { or } \\
\text { more on TPACK definition question }\end{array}$} & \multicolumn{2}{|c|}{$77.5 \%$} & & & & \\
\hline TPACK reflection & $83.5(9.48)$ & 16 & 13 & 9 & 2 & - & 40 \\
\hline $\begin{array}{l}\text { Percentage of student } \\
\text { more on TPACK refle }\end{array}$ & $\begin{array}{l}\text { that score } 80 \% \\
\text { ion question }\end{array}$ & & & & & & \\
\hline
\end{tabular}


Figure 3.2 shows students' interest in the course and in TPACK as reported in the interview. Of the total number of students, 93.5\% were happy and interested in this course about TPACK, $80 \%$ were willing to apply this experience to their future practises, and $37.5 \%$ had already tried out and implemented this experience in their in-school training.

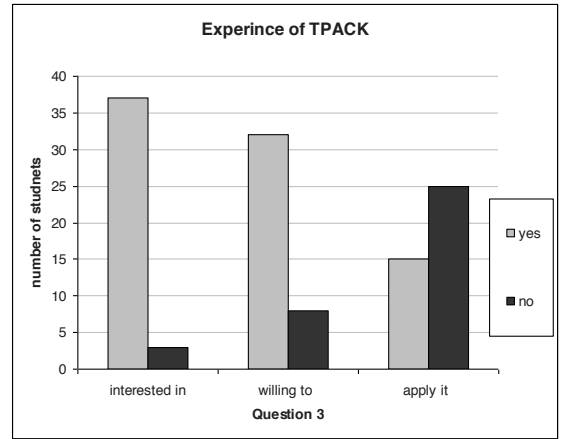

Figure 3.2 Results of the questions related to TPACK experience from DT interview

\subsubsection{The change in ICT skills}

Table 3.10 shows the results of the ICT skills test at the beginning and end of the intervention. The results revealed a significant increase in the score on the ICT skills test $(t=18.25, d f=50, p=0.0001)$ with a large effect size $(d=1.8)$, which indicates that the ICT skills of the participants had developed considerably, but the participants' scores greatly varied in both the pre- and post-tests (SD $=2.82$, and $\mathrm{SD}=3.10$, respectively). The results from the ICT skills questionnaire showed that the pre-service teachers also reported that their skills had increased. There were significant increases in the pre-service teachers' basic ICT skills $(\mathrm{t}=-6.62, \mathrm{df}=54, \mathrm{p}=0.0001)$, confidence in using multimedia tools $(\mathrm{t}=-10.86$, $\mathrm{df}=54, \mathrm{p}=0.0001)$, and email and Internet use $(\mathrm{t}=-8.32, \mathrm{df}=52, \mathrm{p}=0.0001)$ with large effect size ( $d=0.95, d=1.78$, and $d=1.40$, respectively). In relation to their advanced ICT skills, there was a significant increase at the end of the intervention $(t=-2.21, d f=54, p=0.0001)$, but with small effect size $(d=0.39)$. 
Table 3.10 A comparison of the pre-service teachers' pre $\mathcal{E}$ post scores in ICT skill test

\begin{tabular}{|c|c|c|c|c|}
\hline & $\begin{array}{c}\text { Pre } \\
\text { Mean (SD) }\end{array}$ & $\begin{array}{c}\text { Post } \\
\text { Mean (SD) }\end{array}$ & $\begin{array}{c}\mathbf{P} \\
\text { (level of } \\
\text { significance) }\end{array}$ & $\begin{array}{c}\text { Effect } \\
\text { size }\end{array}$ \\
\hline ICT skill test score & $8.98(2.82)$ & $14.21(3.10)$ & .0001 & 1.80 \\
\hline $\begin{array}{l}\text { Minimum }(0) \text {-Maximum } \\
\text { sore }(20)\end{array}$ & $2.25-14.75$ & $7.75-19.75$ & - & - \\
\hline \multicolumn{5}{|l|}{ ICT skills questionnaire } \\
\hline \multicolumn{5}{|c|}{ Things pre-service science teachers do on a computer at school: } \\
\hline Basic skills & $3.28(.745)$ & $3.87(.470)$ & .0001 & .95 \\
\hline Advanced skills & $2.40(.761)$ & $2.69(.748)$ & .031 & .39 \\
\hline \multicolumn{5}{|c|}{ Things pre-service science teachers feel confident to do: } \\
\hline Multimedia tools & $2.58(.789)$ & $3.75(.492)$ & .0001 & 1.78 \\
\hline Email \& internet & $3.30(.794)$ & $4.20(.441)$ & .0001 & 1.40 \\
\hline
\end{tabular}

Note: $1=$ Strongly Disagree (SD); $2=$ Disagree (D), $3=$ Undecided $(\mathrm{U}), 4=$ Agree $(\mathrm{A}) \& 5=$ Strongly Agree (SA).

\subsubsection{The change in attitude toward ICT}

Table 3.11 shows the attitude of the students toward ICT before and after the intervention. The results revealed that there was a significant increase in the instructional and productivity tool scale $(\mathrm{t}=-3.79, \mathrm{df}=60, \mathrm{p}=0.001)$, with a medium effect size $(\mathrm{d}=0.64)$. Enjoyment was higher at the end of the intervention compared to the beginning $(t=-3.11, d f=60, p=0.003)$, with medium effect size $(\mathrm{d}=0.51)$. Anxiety/frustration was slightly lower at the end of the intervention ( $t$ $=0.45, \mathrm{df}=60, \mathrm{p}=0.655)$, but the difference was not significant.

Table 3.11 A comparison of the pre-service teachers' pre \& post attitude toward ICT

\begin{tabular}{|l|l|c|c|c|}
\hline & \multicolumn{1}{|c|}{$\begin{array}{c}\text { Pre } \\
\text { Mean }(S D)\end{array}$} & $\begin{array}{c}\text { Post } \\
\text { Mean (SD) }\end{array}$ & $\begin{array}{c}\text { (level of } \\
\text { significance) }\end{array}$ & $\begin{array}{c}\text { Effect } \\
\text { size }\end{array}$ \\
\hline $\begin{array}{l}\text { Instructional \& } \\
\text { productivity tool }\end{array}$ & $3.87(1.278)$ & $4.57(.892)$ & .0001 & .64 \\
\hline Enjoyment & $3.75(1.286)$ & $4.31(.889)$ & .003 & .51 \\
\hline Anxiety \& Frustration & $2.08(.945)$ & $2.04(.664)$ & .655 & - \\
\hline
\end{tabular}

Note: $1=$ Strongly Disagree (SD); $2=$ Disagree (D), 3= Undecided (U), $4=$ Agree (A) \& 5= Strongly Agree (SA). 


\subsubsection{Pre-service students' experiences with DTs}

The attitude of students toward DTs is shown in Table 3.12. The results show that there is a significant change in all factors. An increase in appreciation of teamwork $(t=-7.28, d f=53, p=0.001)$ was found with a large effect size $(d=$ 0.98 ), indicating that the students appreciated working in the Design Teams. The pre-service teachers also reported an increase in leadership and understanding others $(t=-3.72, d f=53, p=0.001)$, with a small effect size $(d=0.33)$. However, avoidance was lower at the end of the intervention when compared to the start of the intervention $(t=3.83, d f=52, p=0.001)$, with a small effect size $(d=-0.44)$, showing that the pre-service teachers had a positive attitude toward teams and were willing to engage in teamwork at the end of the intervention.

Table 3.12 A comparison of the pre-service teachers' pre $\mathcal{E}$ post attitude toward team

\begin{tabular}{|l|c|c|c|c|}
\hline & \multicolumn{1}{|c|}{$\begin{array}{c}\text { Pre } \\
\text { Mean (SD) }\end{array}$} & $\begin{array}{c}\text { Post } \\
\text { Mean (SD) }\end{array}$ & $\begin{array}{c}\text { P } \\
\text { (level of } \\
\text { significance) }\end{array}$ & $\begin{array}{c}\text { Effect } \\
\text { size }\end{array}$ \\
\hline $\begin{array}{l}\text { Appreciation } \\
\text { Leadership \& understanding } \\
\text { others }\end{array}$ & $3.74(.641)$ & $4.28(.449)$ & .0001 & .98 \\
\hline Avoidance & $3.46(.748)$ & $3.71(.784)$ & .0001 & .33 \\
\hline
\end{tabular}

Note: $1=$ Strongly Disagree (SD); $2=$ Disagree (D), 3= Undecided (U), 4= Agree (A) \& 5= Strongly Agree (SA).

The interview data supported the findings from the Attitude toward Teamwork questionnaire. One pre-service student explicitly mentioned that she liked teamwork, saying "Working in teams gave us the opportunity to learn from each other and we were active throughout the course." Another participant indicated that "Working in Design Teams saves time and effort, because we learn many ICT skills from our teammates during a relatively short period of time."

The participants stated that there are several requirements while working in DTs. They addressed a need for a communications environment in which team members can share files, as well as a means to chat, reflect, and communicate with other team members to reduce the time and effort required for the meeting and design process. Based on the interviews and the logbooks analysis, it was found that the main support needed while working in DTs was technical support on how to use different ICT-tools. All of the addressed needs were related to TPK, TCK and TPACK. However, there was no addressed need 
related to CK, PK, or PCK. Table 3.13 summarizes the required needs and the classification of those needs according to the TPACK framework.

Table 3.13 Summary of support and help needed by pre-service teachers during design process

\begin{tabular}{|c|c|c|c|}
\hline Support or needs & $\begin{array}{c}\text { TPACK } \\
\text { constructs }\end{array}$ & $\begin{array}{c}\mathbf{N} \\
\text { (Number of } \\
\text { students) }\end{array}$ & $\%$ \\
\hline Photo/picture editing (e.g. Adobe Photoshop) & TK & 54 & $88 \%$ \\
\hline Presentation (e.g. PowerPoint) - advanced level. & TK & 49 & $80 \%$ \\
\hline $\begin{array}{l}\text { Sound editing: how to deal with sounds (Sound } \\
\text { recording and editing skills.- Inserting sound in to } \\
\text { video clip- Inserting sound in to power point } \\
\text { presentation). }\end{array}$ & TK & 38 & $62 \%$ \\
\hline Drawing software (e.g. Adobe Illustrator) & TK & 38 & $62 \%$ \\
\hline Video editing & TK & 37 & $60 \%$ \\
\hline $\begin{array}{l}\text { Animation software (e.g. Macromedia Flash, Image } \\
\text { ready) }\end{array}$ & TK & 28 & $45 \%$ \\
\hline Designing and Creating a web pages & TK & 15 & $44 \%$ \\
\hline Spread sheets and tables & TK & 12 & $20 \%$ \\
\hline Data base (e.g. Microsoft Access) & TK & 2 & $3 \%$ \\
\hline $\begin{array}{l}\text { Using multimedia and simulation in science } \\
\text { education }\end{array}$ & TCK & 58 & $95 \%$ \\
\hline Using ICT and computer in science education & TCK & 54 & $88 \%$ \\
\hline $\begin{array}{l}\text { Meeting with experts through video conference to } \\
\text { support the lesson content. }\end{array}$ & TCK & 28 & $46 \%$ \\
\hline How to be efficient web searcher & TCK & 58 & $95 \%$ \\
\hline How to infuse technology in student centred class. & TPK & 59 & $97 \%$ \\
\hline $\begin{array}{l}\text { Examples of using technology in science education } \\
\text { with different teaching strategy and approaches. }\end{array}$ & TPACK & 58 & $95 \%$ \\
\hline
\end{tabular}

The criteria of support as addressed by the students shows that they need a support environment with a user interface in Arabic that could be accessed anytime and anywhere. They also indicated that the support environment should consist of different tutorials related to ICT-tools, and examples of lesson plans that integrate ICT in science education. It is also important to mention that preservice teachers confirmed that the support provided by the different experts was helpful and important to foster the development of TPACK, even though it is time consuming, especially when the expert is needed after the class hour. 


\subsection{CONCLUSION AND DISCUSSION}

The purpose of this study was to determine whether there was a change in TPACK, ICT skills, and attitude toward ICT of the pre-service science teachers who participated in DTs. In order to make an accurate assessment of this, we considered the sub-questions itemized below.

\subsubsection{Was there a change in the TPACK of the pre-service teachers?}

The knowledge of the students prior to the intervention was deducted from the analysis of the data from the TPACK survey at the beginning of the intervention. The results indicated that the participants were unsure about their TK, TCK, TPK, and TPACK at the beginning. But at the end of the intervention, they had developed significantly in different knowledge addressed in the TPACK framework. In relation to the CK, there was no change, similar to the findings of Shin et al. (2009). However in relation to PK, there was a significant difference, which may be because the participants experienced and practiced the student-centred approach during this study, which helps in the development of PK. At the end of the intervention, most of the students were able to define TPACK and describe effective uses of ICT in science education, which reflects the development of their TPACK. The findings also indicate that the students were willing to try what they had learned in this intervention (TPACK) in their future practices.

Working in DTs through learning ICT by design develops the TPACK of the students, and the students were able to understand the relationship between the different knowledge related to TPACK. As Koehler and Mishra (2005) concluded, learning by design for ICT integration appears to be an effective way to develop a deeper understanding of the TPACK framework.

\subsubsection{Did the ICT skills of the pre-service teachers change as a result of working in DTs?}

The results show that the ICT skills of the students increased significantly while they were working in DTs to develop or design a solution for a problem related to the science content by using the suitable pedagogy and ICT tool. So while experimenting with ICT, they developed the practical skills needed to design 
the solution; and different members of the team could learn from each other. This indicates that working in DTs can contribute to the development of skills and a better sense of efficacy of the teachers (Handelzalts 2009; Mishra et al. 2007; Simmie 2007). Or as Kay (2007) concluded, working in an authentic collaborative learning environment could be a suitable strategy to help preservice teachers to learn about ICT integration.

\subsubsection{Did the attitude of the pre-service teachers toward ICT change as a result of working in DTs?}

The findings show that the students developed a positive attitude toward ICT while working in DT to solve authentic educational problems by using a suitable ICT tool. This could be because the pre-service teacher experienced the use of ICT and gained ICT skills, which means the perceived usefulness and perceived ease of ICT increased at the end of the intervention (i.e., teachers probably became more confident and competent in their ICT). And this may enhance their attitude toward ICT, as some researchers concluded (e.g., Potosky \& Bobko 2001; Sime \& Priestley 2005).

\subsubsection{How do the pre-service teachers experience working in DTs?}

The findings indicated that students developed a positive attitude toward teams at the end of the intervention. The answers to the interview questions showed that more than half of the respondents were happy and interested about their experience through the intervention. Working in a DT results in acquiring or fostering the development of TPACK. Although the pre-service teachers appreciate working in DTs, they stressed different needs to support them while working in the DT. All of the addressed needs were related to TK, TPK, TCK, and TPACK, which had the lowest rating at the beginning of the intervention. The criteria for support as required by the pre-service teachers focused mainly on the flexibility of time and access to the support. Workenvironment for teams to share and reflect on the experience or product was mainly for saving time for the DTs.

Was there a change in the knowledge, skills, and attitude of the pre-service science teachers who participated in DTs? 
The findings are encouraging. Not only did different knowledge related to TPACK change positively, but most students who enrolled in this intervention gained an understanding of how ICT is related to other aspects of teaching, such as pedagogy and content, since they were able to define and describe a situation for the TPACK framework. They also gained better ICT skills, since they scored higher in two different instruments for assessing ICT skills compared to their score at the beginning of the intervention. Moreover, their attitude toward both ICT and working in DTs became more positive. This could indicate that the intervention contributes positively in the development of TPACK that the students became more aware of TPACK, and that working in DTs to design and develop a solution for authentic problems fosters the development of TPACK.

Extra time is needed to get used to, and practice this knowledge in real classroom settings. Since TPACK was built on PCK, and as researchers concluded that the development of PCK is mainly influenced by real teaching experiences (e.g., Van Driel, De Jong, \& Verloop 2002), it is assumed that to develop TPACK, a real teaching experience with ICT is also needed. Or as Fishman and Davis (2006) argued, building TPACK goes a long way beyond the formal setting of pre-service education.

Working in DTs is a promising strategy to develop the knowledge, skills, and attitude required to help teachers integrate ICT into their practice. So the results in general are a good starting point to investigate DTs for learning ICT by design to enable pre-service teachers to develop TPACK, which will prepare them to become ICT-integrating teachers. As was concluded by Koehler and Mishra (2005), "learning by design appears to be an effective instructional technique to develop deeper understandings of the complex web of relationships between content, pedagogy and technology and the contexts in which they function" (p. 131).

In addition to the findings in relation to TPACK and working in DTs, the results of this study showed how students could be supported while working in DTs. The students stressed that a support system or environment in the Arabic language which can be accessed anytime and from any place should be available. This support system should include tutorials on different kinds of software, examples of lesson plans that integrate ICT in science education, and 
affordances and constraints of different ICT in relation to the science curriculum. It was suggested that the support environment could also include communication possibilities among team members, between different teams, and with the course instructor. Further research is needed to identify the efficient support and conditions needed to foster the development of the TPACK of pre-service teachers at PAAET. This will act as a first step in providing pre-service teachers with skills, knowledge, and appropriate attitude needed for ICT integration in their future practice. 


\section{CHAPTER 4}

\section{Developing Technological Pedagogical Content Knowledge in pre-service science teachers: The potential of blended support for learning*}

The Technological Pedagogical Content Knowledge (TPACK) framework has been used to prepare pre-service science teachers at the Public Authority of Applied Education and Training in Kuwait for ICT integration in education. Pre-service teachers worked in teams to design an ICT solution for an authentic problem they face during in-school training. Pre-service teachers were separated into two groups. The first group was coached by ICT, pedagogy, and content experts. The second group was offered a blended condition, by which they had access to an online portal with different tutorials and examples. In addition, they had the opportunity to meet with different experts whenever they needed to. Pre-test and post-test design data were collected of pre-service teachers' attitudes toward ICT, their ICT skills, and their TPACK. The findings showed that the self-reported TPACK, the score of attitudes toward ICT, and ICT skills had increased in both groups. However, the blended support condition reported a higher increase in the participants' Technological Knowledge (TK), Technological Pedagogical Knowledge (TPK), their attitude toward ICT as a tool for instruction and productivity, and ICT enjoyment, compared to the human support condition. This indicated that students perceived the blended condition for supporting Design Teams as a more desirable method to enhance their development of TPACK.

Alayyar, G., Fisser, P., \& Voogt, J. (submitted). Developing Technological Pedagogical Content Knowledge in pre-service science teachers: The potential of blended support for learning. Computers and Education. 


\subsection{INTRODUCTION}

How to integrate ICT into teacher preparation programs is drawing educators' attention. They recognize that teaching ICT skills alone does not serve preservice teachers well, because they learn how to operate ICT-related tools without being able to use them effectively to promote students' learning (Graham et al., 2009). To be an ICT-integrating teacher means going beyond ICT skills, and developing an understanding of the complex relationships between pedagogy, content, and ICT (Hughes, 2005; Keating \& Evans, 2001; Lundeberg, Bergland, Klyczek, \& Hoffman, 2003; Margerum-Leys \& Marx, 2002; Niess, 2005; Zhao, 2003). Hence, a teacher preparation program should provide students with the knowledge, skills, and experience needed to integrate ICT effectively in their future practice, taking into account the interactions between pedagogy, content, and ICT.

Mishra and Koehler (2006) introduced Technological Pedagogical Content Knowledge (TPACK) as a framework to understand and describe the kinds of knowledge needed by a teacher for effective ICT integration. The main bodies of knowledge in the TPACK framework are: Content Knowledge (CK), Pedagogical Knowledge (PK), and Technological Knowledge (TK). Besides these main bodies of knowledge, the TPACK framework stresses the importance of the interactions between these bodies of knowledge. These include Pedagogical Content Knowledge (PCK) as addressed by Shulman (1987), Technological Content Knowledge (TCK) referring to how ICT and content influence each other, Technological Pedagogical Knowledge (TPK) addressing how pedagogies change while using ICT, and Technological Pedagogical Content Knowledge (TPACK), which is the knowledge that emerges from interactions among the three knowledge domains (Koehler \& Mishra, 2008).

Koehler, Mishra, and Yahya (2007) suggest that teachers need to work collaboratively in Design Teams (DTs) in order to develop ICT solutions for authentic educational problems. This approach is known as "Learning Technology by Design." In DTs, teachers develop flexible ways of thinking and rethinking about ICT, design, and learning that helps the development of TPACK. Since the main objective of any TPACK intervention is to prepare teachers to become ICT-integrating teachers, teachers' skills and attitudes 
toward ICT also need to be taken into account, because research has shown that skills and a positive attitude are key factors in the likelihood that a teacher will start using ICT in education (Albirini, 2006; Christensen \& Knezek 2008; Mumtaz, 2000; Tearle, 2003).

The development of pre-service teachers' TPACK is a main concern of the science teacher preparation program at the Public Authority of Applied Education and Training (PAAET) in Kuwait. The science teacher preparation program is a four-year program that prepares female teachers as primary science teachers. Students spend three and a half years (i.e., seven semesters) in the college learning theoretical knowledge, while the last semester is devoted to in-school training (Almodaires, 2009). During their in-school training, the students are obliged to take the educational seminar course. The idea behind the educational seminar course is to train pre-service teachers to find solutions for educational problems they face during their in-school training and their future teaching practices. It is within the educational seminar course that the pre-service teachers become acquainted with TPACK.

In a previous study on TPACK development at the science teacher program at PAAET, pre-service science teachers worked in DTs and were coached by technology, pedagogy, and content experts, to find an ICT solution for a real educational problem (Alayyar, Fisser \& Voogt, in press). The findings of this study showed that pre-service teachers reported higher gains in different knowledge domains related to TPACK. However, in relation to CK, there was no significant difference. In the DTs pre-service teachers were able to develop an ICT-enhanced activity and integrate it into their lesson plan.

The pre-service teachers appreciated the support that was given to them. However, the pre-service science teachers also indicated that they would like to have more flexibility in relation to time and accessibility of the support - i.e., an environment that could be accessed any time anywhere, available in the Arabic language. The pre-service science teachers also mentioned their needs which they liked having integrated in the support environment. Those needs were related to the technological aspects of the TPACK framework, such as tutorials on different ICT applications, designing and developing web-pages, providing examples on how to use ICT in student-centred classes, how to meet with 
experts online to discuss topics related to the science content, and providing authentic examples on using ICT in science education.

The pre-service teachers also asked for a communication workplace by which DTs could share and discuss their work during their design process (Alayyar, Fisser \& Voogt, in press). The experts who coached the students indicated that the face-to-face support they provided to the DTs during the course was essential in routing students' thinking toward TPACK and the relationships and interactions among different knowledge domains related to the TPACK framework to aid in TPACK development. However, they also acknowledged that supporting the DTs face-to-face is time consuming.

This study explores the potential of blended support for learning as an efficient way to support the DTs, and tries to confirm the findings from a previous study (Alayyar, Fisser \& Voogt, in press).

\subsection{THEORETICAL FRAMEWORK}

Flexibility related to time and delivery was indicated by the students and instructors as an important feature of an online environment to support the development of TPACK in DTs. Offering this kind of flexibility means that the students can learn whenever and wherever they want (Collis \& Moonen, 2001). However, students in the teacher preparation program at PAAET are used to learning in a teacher-centred approach, where the teacher is the instructor (Alayyar, Fisser and Voogt, submitted a). An online environment that completely replaces the support of the expert instructors therefore may not be an effective strategy. In addition, as Graham (2006) reports, "many learners want the convenience offered by a distributed environment, yet do not want to sacrifice the social interaction and human touch of face-to-face learning" (Graham, 2006, p. 9). For this reason, this study explored a blended approach to support the DTs.

Littlejohn and Pegler (2007) argued that "blending is an art that has been practised by inspirational teachers for centuries. It centres on the integration of different types of resources and activities within a range of learning environments where learners can interact and build ideas" (p. 1). Masie (2002) indicated that blended learning is the use of two or more distinct methods, 
which may include combinations such as blending classroom instruction with online instruction, blending online instruction with access to a coach or faculty member, or blending simulations with structured courses. Blended learning is therefore not a single method of learning; nor is it a separate alternative to online learning or face-to-face learning methods (Hinkelman, 2005). Rather, it refers to any style of learning that combines different learning and delivery methods. In this study, we refer to blended support for learning as the combination of online, and face-to-face support for learning.

Research on blended learning has shown that integrating online sessions with face-to-face courses can improve student interactions and satisfaction (Delacey \& Leonard, 2002; So \& Brush, 2008). Thomson (2003) reported that students who studied through a blended approach learned faster than those studying through online courses only. Graham, Allen, and Ure (2003) found that blended learning was adopted for three main reasons: 1) improved pedagogy, 2) increased access or flexibility, and 3) cost effectiveness. In addition, some researchers argued that blended learning increases the level of active learning, peer-to-peer learning, and student-centred strategies (Collis, Bruijstens \& Veen, 2003).

However, creating an effective blended learning environment is challenging and depends on the context. Among the challenges of blended learning is that first, it is time consuming for instructors, especially when transforming a traditional course into a blended one, while students expect more frequent feedback and interaction than in a face-to-face learning environment (Alebaikan \& Troudi, 2010; Graham et al., 2003). Second, it is difficult to find the right design for blended learning. Although blended learning can provide the best of all worlds, Graham (2006) warned that it can also provide the worst of all worlds if it is not carried out carefully. Neumeier (2005) concluded that the most important aim of blended learning design is to find the most effective and efficient combination of learning modes for the content, context, and objectives to create a learning environment that works as a whole. Among other challenges of blended learning are the culture of the educational institute or organisation in relation to comfort level for using ICT in education; the level of students' self-discipline; organizational and managerial support; students' responsiveness (Graham et. al., 2003); and societal norms and values (Alebaikan \& Troudi, 2010). 
To design a blended learning environment that can overcome these challenges, Sale (2009) proposed that it is important to introduce ICT in a way that significantly enhances the design of the environment. This can be done by: 1) developing an awareness of the unique capabilities of the online environment and of ICT tools (i.e., access to online resources anytime and anywhere; Hyperlink dynamic content; and social networking); and 2) identifying the pedagogical uses and affordances of ICT tools (e.g., Web2.0 tools enable synchronous and asynchronous communication media).

With the potential of blended learning in mind, an online support learning environment was developed. The online support learning environment in particular was expected to provide pre-service teachers with an in-depth experience of the potential benefits of ICT for student learning through demonstrating the potential of ICT as an effective tool to deliver parts of the content, supplementary resources, and support to learners; and through providing opportunities for ICT-supported social communication between team members, instructors, and different teams or classmates. It was expected that when pre-service teachers experience and practice working in the blended support for learning, they may move toward active learning, peer-to-peer learning, and student-centred strategies as described by Collis et al. (2003). Through the online discussion forum, the pre-service teachers could post questions, answer questions, or reflect on discussions online, and thus could increase the participation rate in the discussion (Hsi, 1997) and foster deep thinking (Moore, 2002), because writing a message requires thoughtful thinking (Chen \& Looi, 2007). This in turn would lead to the development of complex perspectives on the addressed topic (Prain \& Lyons, 2000). Moreover, exploring the exemplary lesson materials available online would help the participants get a better understanding of ICT integration (Voogt, Almekinders, Van den Akker \& Moonen, 2005), thereby helping in the development of TPACK. In addition, the pre-service teachers would become more independent learners. Access to the online environment with certain tasks and activities expected to increase the preservice science teachers' attitude, competence, and confidence toward integrating ICT in teaching and learning would foster the development of TPACK. 


\subsection{THE INTERVENTION}

In the study two kinds of support for learning were distinguished: human support and online support. The human support was provided by the three different experts on pedagogy, science content, and ICT, respectively. The online support was an online support portal in Moodle which is an open source for learning management system. The portal contained tutorials on how to use different kinds of software, examples of lesson plans that integrate ICT, a matrix of different ICT applications with suitable teaching methods, and examples or URL links on using ICT in science education. The portal also supported online expert support through a chat tool and offered a workplace for DTs to share documents, a discussion forum to reflect on what's going on in class, and to answer a weekly question. Next to this there were news messages, a calendar with upcoming events, and resources by which different students were asked to add links that they thought would be helpful.

The students participating in the study were divided into two conditions; Human Support (HS) and Blended Support (BS). In the HS-condition, the experts supported the pre-service science teachers through face-to-face meetings during class time or during office hours in relation to the process of designing the ICT lesson activities as a solution for the addressed pedagogical problem and to identify the best teaching strategy that could be used for the specific content with the appropriate ICT. In the BS-condition, the experts did not attend the class, unless there was a need from DTs. However, the DTs in the BS-condition had access to the online support environment.

The intervention took place during the spring semester of 2010. It lasted for 12 weeks, two hours per week; 78 students were registered in three sections of "Educational Seminar" course with two instructors. One instructor taught two groups: one group with the HS-condition (22 students) and one group with the BS-condition (31 students). The other instructor supervised another group in the BS-condition (25 students). To introduce the pre-service students to TPACK and to form the DTs, a workshop was organized during the first four weeks for both groups.

During the last day of the workshop, students were asked to form a DT of three to four members. The DTs had to identify one topic (content related to the 
primary science curriculum), to be taught with ICT. Next, the researcher presented the online support environment for the groups that were assigned to participate in the BS-condition. In the fifth week, both the HS and the BS group were asked to present their problem and the possible ICT solution for their peers and the experts. During this presentation, peers and experts reflected on the problem, the suggested ICT-tool, and on the suggested pedagogy.

From week 5 through week 10, the instructors started the HS class by posing a weekly question or statement, which the students were asked to answer or reflect on. The experts also joined the discussion. For the BS group, the question or statement was available online and the students needed to write their reflection in the discussion forum within the online environment. In this period, the DTs designed their solution for the addressed problem. For the HS group, the different experts attended the class to support the DTs during the design process. The BS groups were asked to use support available online and to meet with the experts only when needed.

In week 11, the teams were asked to present their solution to the experts and their peers. The teams were also asked to submit a CD-ROM containing their product with a paper describing their lesson plan and their ICT integration plan explaining the role of the teacher and the student. The products of both groups were evaluated by the different experts. In the last week, all students were asked to answer the different questionnaires again and the HS group was asked to register in the online support environment and browse the site. Finally, interviews were conducted with the different teams.

\subsection{Problem STATEMENT AND RESEARCH QUESTIONS}

This study is concerned with developing TPACK in pre-service teachers through working in DTs in the science teacher preparation program at PAAET. Based on the findings of a previous study (Alayyar, Fisser, \& Voogt, in press), we expected that supporting DTs by technological, pedagogical, and content experts would be helpful in the development of TPACK. The study wanted to test whether Human Support (HS) and Blended Support (BS) would have a different effect on pre-service teachers' development of TPACK .In addition we 
also aimed to confirm the findings of the previous study. This study seeks answers to the following research questions:

RQ1: Does working in Design Teams (DTs) develop pre-service teachers' knowledge, skills, and appropriate attitude needed for ICT integration?

RQ2: Does Human Support (HS) and Blended Support (BS) for learning have a different effect on pre-service teachers' development of TPACK, and on their attitude and skills related to ICT?

RQ3: How do pre-service teachers experience Blended Support (BS) for learning?

\subsection{Methodology}

\subsubsection{Participants}

The participants in this study were 78 pre-service teachers from the science teacher preparation program at PAAET. All of the students were registered in the "Educational Seminar" course with two instructors. The "Educational Seminar" course was accompanied by an in-school field training in the final semester of the educational program. All pre-service teachers were female, with an average age of 23 years. The participants had science either as their major or minor specialization.

Almost all of the participants had a computer at home and about $96 \%$ of the participants indicated that they had an Internet connection at home. About 88\% of the participants indicated that they had access to a computer at the department at PAAET and $73 \%$ of the participants indicated that they had Internet access at their department.

\subsubsection{Instruments}

Six different instruments were used in this study to measure the TPACK of the pre-service teachers, their attitude toward ICT, their ICT-related skills, their experience with working in DTs, and the support they experienced Table 4.1 shows a general overview of the different instruments used in this intervention and their purpose. 
Table 4.1 Overview of the different instruments used in this intervention

\begin{tabular}{|c|c|c|c|c|c|}
\hline \multicolumn{2}{|c|}{ Instruments } & Purpose & RQ1 & RQ2 & RQ3 \\
\hline \multicolumn{2}{|c|}{ TPACK survey } & Perceived TPACK development & $x$ & $x$ & \\
\hline \multicolumn{2}{|c|}{ Attitude to ICT } & Change in attitude to ICT & $x$ & $x$ & \\
\hline \multirow{2}{*}{$\begin{array}{l}\text { ICT skill } \\
\text { tools }\end{array}$} & ICT skill test & Change in ICT skills & $x$ & $x$ & \\
\hline & ICT skill survey & Perceived change in ICT skills & $x$ & $x$ & \\
\hline \multicolumn{2}{|c|}{ Team logbook } & $\begin{array}{l}\text { Experience during the } \\
\text { intervention }\end{array}$ & & & $x$ \\
\hline \multicolumn{2}{|c|}{ Interview } & Opinion of the BS & & & $x$ \\
\hline \multicolumn{2}{|c|}{ TPACK reflection question } & $\begin{array}{l}\text { Assess pre-service teachers: } \\
\text { understanding of TPACK } \\
\text { ability to apply TPACK } \\
\text { framework in real life }\end{array}$ & & $x$ & \\
\hline
\end{tabular}

\section{The TPACK survey}

The TPACK survey (Schmidt, Bran, Thompson, Koehler, Shin, \& Mishra, 2009) was used at the beginning and at the end of the intervention. This instrument uses a five-point Likert scale: 1) strongly disagree, 2) disagree, 3) neither agree nor disagree, 4) agree, and 5) strongly agree. The items included in this instrument measure pre-service teachers' self-assessments of the TPACK domains. The data from the survey was used to measure a perceived change in TPACK. The TPACK survey was translated to the Arabic language and reviewed by two educational technology experts. The Arabic instrument had a reliability of Cronbach's alpha between 0.72 and 0.86 on the different domains related to the TPACK framework of the instrument.

\section{Attitude toward the ICT Questionnaire}

The attitude toward the ICT Questionnaire to measure the attitude of the preservice science teachers toward ICT was adapted from the Teachers' Attitude toward Computers Questionnaire (TAC) (Christensen \& Knezek, 1996). Six items were added to the TAC about the importance of ICT for learning. The adapted instrument was translated into the Arabic language and reviewed by two educational technology experts to ensure that the pre-service teachers fully understood the items. A factor analysis was conducted from which three scales emerged, which were labelled "Instructional and productivity tool," "Enjoyment," and "Avoidance and frustration." The number of items in each scale was 10, 9, and 7, respectively, and the Cronbach's alpha was $\alpha=0.82, \alpha=$ 0.81 , and $\alpha=0.88$, respectively. 


\section{The ICT skills tools}

This instrument consists of two parts, the ICT skills test and the ICT skills questionnaire. The ICT skills test is a performance attainment scale used to measure the specific technological skills of the students at the start and at the end of the intervention. This test was designed by the researcher, and consists of six questions that measure different skills, such as dealing with the operating system and proficiency with the Microsoft office suite, the Internet, Adobe Photoshop, and multimedia editing software. The test was reviewed by an educational technology expert and the reliability of the test was 0.85 . The ICT skills questionnaire is a self-report measure and was created by combining two existing instruments: the national survey on information technology in teacher education by the Milken Exchange on Educational Technology (1999) and the Technology Proficiency Self-Assessment (TPSA) by Ropp (1999).

The researcher added some items to assess more advanced ICT skills, such as video conferencing, multimedia production, and simulations. This instrument was translated into the Arabic language and reviewed by two educational technology experts. The questionnaire has two main scales: "things participants can do on a computer at school" and "things participants feel confident to do on a computer." A factor analysis was conducted, from which two sub-scales emerged for each scale. From the first scale, subscales "basic skills" and "advanced skills" emerged. The number of items in each subscale was 7 and 3, and the Cronbach's alpha was a $=0.86$ and $\alpha=0.87$, respectively. And from the second scale, subscales "multimedia tools" and "email and Internet" emerged. There were seven items in each subscale, and the Cronbach's alpha was $\alpha=0.83$ and $\alpha=0.84$, respectively.

The team logbook

At the end of the course, the teams were asked to submit a logbook that included the problems they faced during the design process, how these problems were solved, and from whom they got support and assistance.

Teams' interviews about the blended support

A semi-structured interview for the DTs was used to see how the BS was valued. This instrument was divided into two parts: the first part dealt with teams that experienced the BS. The questions for these teams were:

- Did you enjoy the blended approach during this course?

- Are you satisfied with the support during the blended approach during this course? 
- Would you like to experience or use this approach again?

- Do you think that the blended approach was helpful? Why?

The second part of the instrument was for the teams that experienced HS. These teams were given permission to join the online environment at the end of the intervention. The questions for these teams were:

- What do you think of the online support environment?

- Would it have been helpful for you to use this kind of support during the course?

- Do you think this support can replace or blend with the human support that you experienced during this course?

\section{TPACK reflection questions}

At the end of the course, all students were asked to individually write an answer to two TPACK questions:

- What do we mean by TPACK?

- Describe the situation where you effectively could combine the content with ICT and a specific teaching approach in a classroom lesson. Please include in your answer a description of the content, objectives, target group, teaching approaches, ICT, and teachers' and students' roles in relation to ICT.

These questions were meant to assess pre-service students' understanding of TPACK and whether they could relate TPACK to their practice or experience during their in-school training or within their preparation program.

\subsubsection{Data analysis}

Means and standard deviations were calculated. The $t$-test was used to compare the difference between the pre- and post-tests, and HS and BS group measurements. If the result of the $t$-test was significant, the effect size (Cohen's d) was calculated to get an indication of the magnitude of the effect. Cohen (1988) provided tentative benchmarks for the interpretation of effect sizes: $d=0.2$ small, $\mathrm{d}=0.5$ medium, and $\mathrm{d}=0.8$ large effect size. The data from the TPACK reflection questions were analysed by using the TPACK reflection rubric (Alayyar, Fisser, \& Voogt, in press). The logbooks were analysed by grouping the logs into three main categories: ICT tools (TK), problems/questions, and support provider. The ICT tools were subdivided into different groups depending on their main functions. Questions or problems were clustered in design principles, content- 
related items, or pedagogy-related items. Support providers were categorized according to the person or resource that provided help to the students or teams.

\subsection{ResUlts}

\subsubsection{Development of knowledge and skills and attitude toward ICT while working in DTs}

The results of the TPACK survey are summarized in Table 4.2. The results showed that the respondents reported significant gains on the different knowledge domains related to the TPACK framework with a large effect size when comparing the post- and pre-test data.

Table 4.2 Comparison of the pre-service teachers' perception of their TPACK

\begin{tabular}{|l|c|c|c|c|}
\hline Factor & $\begin{array}{c}\text { Pre } \\
\text { Mean }(S D)\end{array}$ & $\begin{array}{c}\text { Post } \\
\text { Mean (SD) }\end{array}$ & $\begin{array}{c}\text { P } \\
\text { (level of significance) }\end{array}$ & Effect size \\
\hline TK & $3.15(.536)$ & $3.81(.501)$ & 0.0001 & 1.3 \\
\hline CK & $3.54(.723)$ & $4.13(.372)$ & 0.0001 & 1.03 \\
\hline PK & $3.65(.488)$ & $4.28(.367)$ & 0.0001 & 1.5 \\
\hline PCK & $3.57(.692)$ & $4.24(.460)$ & 0.0001 & 1.1 \\
\hline TCK & $3.19(.649)$ & $4.24(.489)$ & 0.0001 & 1.9 \\
\hline TPK & $3.07(.403)$ & $4.24(.420)$ & 0.0001 & 2.8 \\
\hline TPACK & $3.00(.464)$ & $4.13(.403)$ & 0.0001 & 2.6 \\
\hline
\end{tabular}

Note: 1 = Strongly Disagree (SD); 2 = Disagree (D), 3 = Undecided (U), 4 = Agree (A) \& 5 = Strongly Agree (SA).

Table 4.3 summarizes the results for both the ICT skills test and the ICT survey. The results from the ICT skills test showed that there was a significant increase in students' scores, with a large effect size $(\mathrm{d}=1.99)$. The results from the ICT skills survey showed that there was a significant difference at the end of the intervention on the scales related to the basic skills of ICT with a medium effect size $(\mathrm{d}=0.60)$, and for "multimedia tools" and "email and Internet," with a large effect size for both $(\mathrm{d}=1.40$ and $\mathrm{d}=0.96$, resp.). However, no significant difference was found for the advanced ICT skills. 
Table 4.3 Comparison of pre-service teachers' pre \& post ICT skills

\begin{tabular}{|c|c|c|c|c|}
\hline & $\begin{array}{c}\text { Pre } \\
\text { Mean }(S D)\end{array}$ & $\begin{array}{c}\text { Post } \\
\text { Mean (SD) }\end{array}$ & $\begin{array}{c}\mathbf{P} \\
\text { (level of } \\
\text { significance) }\end{array}$ & Effect size \\
\hline ICT skill test score & $7.75(3.078)$ & $13.89(3.100)$ & .0001 & 1.99 \\
\hline $\begin{array}{l}\text { Minimum (0) - } \\
\text { Maximum score (20) }\end{array}$ & $2-15$ & $6-19.5$ & & \\
\hline \multicolumn{5}{|c|}{ ICT skills questionnaire } \\
\hline \multicolumn{5}{|c|}{ Things pre-service science teachers do on a computer at school: } \\
\hline Basic skills & $3.45(.665)$ & $3.78(.420)$ & .0001 & .60 \\
\hline Advanced skills & $2.71(.870)$ & $2.70(.813)$ & 1.000 & - \\
\hline \multicolumn{5}{|c|}{ Things pre-service science teachers feel confident to do: } \\
\hline Multimedia tools & $3.00(.644)$ & $3.76(.522)$ & .0001 & 1.40 \\
\hline Email \& internet & $3.65(.633)$ & $4.20(.500)$ & .0001 & .96 \\
\hline
\end{tabular}

Note: 1 = Strongly Disagree (SD); 2 = Disagree (D), 3 = Undecided $(\mathrm{U}), 4=$ Agree $(\mathrm{A}) \& 5=$ Strongly Agree (SA).

The participants' attitude toward ICT is summarized in Table 4.4. Results showed a significant increase for "ICT as a tool for instruction and productivity" and "enjoyment." The effect size was medium for enjoyment $(d=0.60)$ and large for instructional and productivity tool $(\mathrm{d}=1.15)$. Anxiety and frustration had reduced significantly at the end of the intervention with a medium effect size $(d=-0.52)$.

Table 4.4 Comparison of the pre-service teachers' pre E post attitude toward ICT

\begin{tabular}{|l|c|c|c|c|}
\hline Factors & $\begin{array}{c}\text { Pre } \\
\text { Mean (SD) }\end{array}$ & $\begin{array}{c}\text { Post } \\
\text { Mean (SD) }\end{array}$ & $\begin{array}{c}\text { P } \\
\text { (level of } \\
\text { significance) }\end{array}$ & $\begin{array}{c}\text { Effect } \\
\text { size }\end{array}$ \\
\hline $\begin{array}{l}\text { Instructional \& } \\
\text { productivity tool }\end{array}$ & $4.00(.451)$ & $4.47(.362)$ & .0001 & 1.15 \\
\hline Enjoyment & $3.93(.478)$ & $4.22(.492)$ & .0001 & .60 \\
\hline Anxiety \& Frustration & $2.58(.769)$ & $2.21(.642)$ & .0001 & -.52 \\
\hline
\end{tabular}

Note: 1 = Strongly Disagree (SD); 2 = Disagree (D), 3 = Undecided $(\mathrm{U}), 4=$ Agree $(\mathrm{A}) \& 5=$ Strongly Agree (SA).

\subsubsection{The difference between Human support and Blended support groups in relation to change in TPACK skills and attitude toward ICT}

The results of the growth in different knowledge related to TPACK for the HScondition and the BS-condition are summarized in Table 4.5. The gains for the 
different knowledge domains for respondents in the BS condition was higher for all factors except PCK. However, only the gains in TK and TPK were significant $(p=0.013$ and $p=0.024$, resp.), with a medium effect size $(d=0.75$ and $\mathrm{d}=0.73$, resp.).

Table 4.5 Comparison of the change in TPACK (post - pre) in HS and BS groups

\begin{tabular}{|c|c|c|c|c|}
\hline Factor & $\begin{array}{c}\text { HS } \\
\text { Mean (SD) }\end{array}$ & $\begin{array}{c}\text { BS } \\
\text { Mean (SD) }\end{array}$ & $\begin{array}{c}\mathbf{P} \\
\text { (level of significance) }\end{array}$ & Effect size \\
\hline Change in TK & $.42(.435)$ & $.74(.418)$ & .013 & .75 \\
\hline Change in CK & $.54(.985)$ & $.61(.597)$ & .789 & \\
\hline Change in PK & $.55(.589)$ & $.65(.436)$ & .528 & \\
\hline Change in PCK & $.74(.806)$ & $.61(.728)$ & .544 & \\
\hline Change in TCK & $.84(.834)$ & $1.01(.684)$ & .259 & \\
\hline Change in TPK & $.88(.543)$ & $1.23(.407)$ & .024 & .73 \\
\hline Change in TPACK & $1.07(.605)$ & $1.13(.438)$ & .716 & \\
\hline
\end{tabular}

The results of the open questions on TPACK definition and examples are shown in Table 4.6. Participants in the BS-condition were able to define the TPACK framework significantly better than the participants in the HS-condition $(\mathrm{p}=$ $0.0001)$ with a large effect size $(\mathrm{d}=1.03)$. Participants in the BS-condition also scored significantly higher than the participants in the HS-condition in their description of a situation where they can apply TPACK $(p=0.0001)$, with a large effect size $(\mathrm{d}=1.50)$.

Table 4.6 Comparison of TPACK reflection question for HS and BS groups

\begin{tabular}{|c|c|c|c|c|}
\hline Question & $\begin{array}{c}\text { HS } \\
\text { Mean (SD) }\end{array}$ & $\begin{array}{c}\text { BS } \\
\text { Mean (SD) }\end{array}$ & $\begin{array}{c}\mathbf{P} \\
\text { (level of significance) }\end{array}$ & Effect size \\
\hline TPACK definition & $48.4(21.35)$ & $70.1(20.83)$ & .0001 & 1.03 \\
\hline TPACK example & 47.9 (19.77) & $75.1(17.69)$ & .0001 & 1.50 \\
\hline
\end{tabular}

Note: The score is out of 100 .

Table 4.7 shows a summary of the change in attitude related to ICT for the BScondition and the HS-condition. Change in both factors, "instructional and productivity tool" and "enjoyment," were significant $(p=0.001$ and $p=0.04$, resp.) in favour of the BS-condition with a large effect size $(\mathrm{d}=1.06)$ for instructional and productivity tool, and a medium effect size $(\mathrm{d}=0.63)$ for enjoyment. 
Table 4.7 Comparison of the attitude toward ICT for HS and BS groups

\begin{tabular}{|c|c|c|c|c|}
\hline & HS & BS & $\mathbf{P}$ & \\
\hline Factors & Mean (SD) & Mean (SD) & $\begin{array}{l}\text { (level of } \\
\text { significance) }\end{array}$ & $\begin{array}{c}\text { Effect } \\
\text { size }\end{array}$ \\
\hline $\begin{array}{l}\text { Change in } \\
\text { Instructional \& productivity } \\
\text { tool }\end{array}$ & $.14(.406)$ & $.61(.475)$ & .001 & 1.06 \\
\hline $\begin{array}{l}\text { Change in } \\
\text { Enjoyment }\end{array}$ & $.06(.431)$ & $.37(.552)$ & .04 & .63 \\
\hline $\begin{array}{l}\text { Change in } \\
\text { Avoidance \& frustration }\end{array}$ & $-.50(.515)$ & $-.34(.697)$ & .45 & - \\
\hline
\end{tabular}

No significant differences were found between both conditions in gains on the ICT skill test and ICT skill survey. The results are shown in Table 4.8.

Table 4.8 Summary of descriptive statistics for the score of ICT skill test for both groups

\begin{tabular}{|c|c|c|c|c|c|}
\hline & & HS & BS & $\mathbf{P}$ & \\
\hline & & Mean (SD) & Mean (SD) & $\begin{array}{c}\text { (level of } \\
\text { significance) }\end{array}$ & $\begin{array}{c}\text { Effect } \\
\text { size }\end{array}$ \\
\hline \multicolumn{6}{|l|}{ ICT skill test } \\
\hline Score - & Pre & $6.91(3.4)$ & $8.08(2.91)$ & .16 & \\
\hline Score - & Post & $13.21(3.18)$ & $14.15(3.04)$ & .24 & \\
\hline Gain & & $6.42(2.33)$ & $6.20(2.17)$ & .70 & \\
\hline \multicolumn{6}{|c|}{ ICT skills questionnaire } \\
\hline \multicolumn{6}{|c|}{ Things pre-service science teachers do on a computer at school } \\
\hline \multirow{2}{*}{ Basic skills } & Pre & $3.50(.763)$ & $3.43(.628)$ & .73 & \\
\hline & Post & $3.82(.433)$ & $3.77(.419)$ & .69 & \\
\hline \multirow{2}{*}{ Advanced skills } & Pre & $2.48(.910)$ & $2.81(.846)$ & .19 & \\
\hline & Post & $2.58(.779)$ & $2.74(.828)$ & .43 & \\
\hline \multicolumn{6}{|c|}{ Things pre-service science teachers feel confident to do: } \\
\hline \multirow{2}{*}{ Multimedia tools } & Pre & $2.99(.715)$ & $3.00(.619)$ & .95 & \\
\hline & Post & $3.79(.429)$ & $3.75(.559)$ & .86 & \\
\hline \multirow{2}{*}{ Email \& internet } & Pre & $3.72(.671)$ & $3.61(.620)$ & .54 & \\
\hline & Post & $4.26(.406)$ & $4.18(.510)$ & .64 & \\
\hline \multicolumn{6}{|c|}{ Change $=($ Post - Pre $)$} \\
\hline Basic skills & & $.35(.720)$ & $.30(.610)$ & .77 & \\
\hline Advanced skills & & $.09(.665)$ & $-.04(1.022)$ & .62 & \\
\hline Multimedia tools & & $.78(.622)$ & $.79(.553)$ & .94 & \\
\hline Email \& internet & & $.55(.484)$ & $.59(.512)$ & .78 & \\
\hline
\end{tabular}

Note: The score of ICT skill test is out of 20. 


\subsubsection{Blended support experience of the pre-service teachers' experience during the intervention}

From the teams' logbook, it was found that the BS-condition group tried to solve its ICT-related problems directly by using the online support environment. Most of the teams in the BS-condition asked to meet the experts about design principles, or about the progress of their product. The BS-condition group rarely asked about ICT-related skills. In addition to the questions the BS-condition was asking, the teams in the HS condition also asked questions about ICT-related technical skills. In general, the addressed problems of the teams were mainly about the technical aspect of the TPACK framework: TK, TPK, TCK, and TPACK, but were hardly related to other aspects of TPACK: PK, CK, and PCK, as was also found in the previous study (Alayyar, Fisser \& Voogt, in press).

Looking to the results from the interview with the BS teams, all of the teams indicated that they enjoyed their experience with the BS approach, and would like to have this experience through the whole program. They found the online environment helpful and gave a number of reasons why. One team indicated that this kind of support saved them time and effort, as they did not need to wait until they could meet with the experts to ask for an explanation or solution. Another team argued that through this approach they became less dependent on the instructor. They could solve their problems directly whenever it arose at any place and time. Furthermore, different teams argued that through the BScondition, they learned about ICT-tools while they were working and accessing the online support. Also, some teams indicated that providing examples of lesson plans that integrate ICT and the use of different ICT applications in the science classroom gave them a deeper understanding of how to integrate ICT in science education, and it gave them the opportunity to think differently about ICT than the way they were using ICT in their daily life for science education. They also addressed the importance of the discussion forums available through the site to share their ideas with their peers and different experts for a deeper understanding of issues related to the design or the course.

When looking at the answers of the HS-condition on the interview after visiting and exploring the online support environment, almost all HS teams were upset about not being able to access the online support environment during the intervention, and they indicated that if they were allowed to use it during the intervention, they would have gained higher results and their product would be 
better. They confirmed that this kind of support should be used with the availability of the HS at the same time and not alone, because they still needed the instructor to guide them in the face-to-face environment, as some teams clarified.

\subsection{CONCLUSION AND DISCUSSION}

The purpose of this study was to explore whether providing Blended Support is an efficient alternative to support the development of TPACK in the pre-service science teachers while working in DTs. In addition, to confirm the findings from the previous study that working in DTs to design an ICT-enhanced lesson is a promising way for the development of TPACK in pre-service science teachers.

This study confirmed the findings of our previous study (Alayyar, Fisser \& Voogt, in press) that working in DTs had a positive effect on teachers' development of TPACK. We found that students perceive that working in DTs led to the development of all domains related to TPACK. In addition, we found that the pre-service teachers gained more ICT skills and developed a better attitude toward ICT. This indicates that the teachers became more ICT competent and probably also more confident in using ICT in their teaching. From these results, we conclude that working in DTs could indeed be a suitable approach to develop TPACK for effective ICT integration. Our findings are comparable to other studies that use an approach in which teachers work together to develop an ICT-enhanced solution for authentic pedagogical problems (e.g., Angeli \& Valanides, 2009; Koehler, Mishra, \& Yahya, 2007; Neo, 2005; Shin et al., 2009; So \& Kim, 2009).

Supporting DTs with appropriate guidance during the design process is important, especially when ICT integration and working in teams are new learning approaches, as is the case in this study. Both the Human Support and Blended Support conditions showed significant positive effects on teachers' attitudes, knowledge, and skills that are needed for ICT integration, leading to the conclusion that both the HS-condition and the BS-condition are successful alternatives for supporting pre-service teachers. Under the Blended Support condition, the findings indicated higher gains in attitudes towards ICT, in Technological Pedagogical Knowledge, and in Technological Knowledge. No 
differences were found in anxiety and frustration toward computers, ICT skills (test and survey), and - except for TK and TPK -other aspects of TPACK.

Compared to the HS group, the BS group's attitude toward the computer as an instructional and productivity tool, and their enjoyment of working with ICTtools were higher. This can be explained by the fact that the BS group had more flexible options to access online support whenever they needed it. The online environment also gave them the opportunity to explore and discuss the affordances and constraints of different ICT-tools, and the pedagogical use of ICT during the available time more deeply, instead of only focusing on separate ICT skills. Similar findings were also found in the studies of Voogt, Almekinders, van den Akker, and Moonen (2005) and Yang and Chen (2010).

The higher gain in TK in the BS group may be attributed to the fact that the participants from the BS-condition were using ICT (the online support environment) while they were learning about ICT (i.e., learning by doing), which may have increased their confidence in their TK compared to their peers in the HS-condition. However, it is interesting that although the participants in the BS-condition gained more in TK, no significant difference was found between the two groups in relation to their gain in ICT skills, as measured in the ICT skills test and the ICT skills survey. This may be due to the fact that the scores for TK were derived from the TPACK survey, which is a self-reported instrument that measures pre-service teachers' self-efficacy in TK. A closer inspection of the items that construct TK show that it measures a general understanding of technology (e.g., "I know about a lot of different technologies"), while the ICT skills survey measures how the pre-service teachers perceive their ability to use specific ICT applications (e.g., "I can edit video clips by using video editing software," and "I can animate an object to explain a phenomenon or process").

In addition, the ICT skills test measures pre-service teachers' ICT skills. This implies that the BS group had more confidence in its general understanding of technology compared to the HS group, but that the support offered (either blended or human) did not make a difference in their ICT skills, nor in their perceived ability to use specific ICT applications. One may wonder whether the TK scale in the TPACK survey is an adequate measure, if one intends to measure pre-service teachers' skills to use ICT in teaching and learning. Graham 
and his colleagues (2009) also had more concrete factors in relation to TK in their instruments to assess TPACK, such as "save an image from a website," "send an email with attachment," "create and edit digital video," and "use web2.0 technology." This shows that it is not yet very clear what kind of knowledge (declarative, procedural, or both) TK encompasses as a specific knowledge domain.

The BS-condition seemed to be more effective related to the development of TPK. This may be because the online environment offered the participants in the BS-condition experiences on how ICT could be used to deliver a part of the content or support to learners. This may have provided the participants a better idea about the potential of ICT for student learning, and it may have increased their confidence in their TPK (e.g., Szabo \& Schwartz, 2011; Voogt, Almekinders, van den Akker, \& Moonen, 2005).

Although the participants in the BS-condition did not have higher gains on TPACK (the integral measure) than their peers in the HS-condition, they were able to define TPACK more accurately, and were better able to explain and reflect on their experiences about TPACK in the design and teaching process. This may be attributed to the online discussion forum, which invites learners to spend more time to think deeply before giving their answers (Moore, 2002), which in turn may lead to a deeper understanding of the addressed topic. We also know that written messages are often produced more thoughtfully than spoken messages, for instance, a class discussion (Chen \& Looi, 2007). These findings show that measuring TPACK through self-reported questions does not necessarily show that teachers developed TPACK. However, if we consider the TPACK survey as a self-efficacy instrument, the findings do show that teachers' confidence in using ICT for teaching and learning has developed in both conditions.

In general, it seems that the TPACK framework cannot be assessed by one single instrument. As Doering, Scharber, Miller, and Veletsianos (2009) concluded, "TPACK needs to be investigated from a number of complementary angles that contribute to a holistic assessment of how teachers teach with ICT." We therefore recommend developing valid and reliable instruments that measure pre-service teachers' TPACK through observable measures - e.g., by demonstrating their ability to integrate ICT in lesson plans or classroom practice. 
Based on the results of our study, we can see that the pre-service teachers in the BS condition were satisfied with the kind of support they received. Mainly, they appreciated the combination of the support and guidance provided by the instructors and the flexibility of the online environment. The ability to access the online environment any time, any place, whenever they needed to, saved them time and effort while working in the DTs with their peers. The online tutorials, the different examples of lesson plans that integrate ICT, the different examples of ICT-tools and their potential use in education that was available online gave them the opportunity to explore different technological tools and suitable teaching methods and to decide which ICT would best meet their needs. The online discussion forum was found to be very helpful, because the pre-service teachers could exchange their ideas and opinions and get instant feedback from team members, peers, or experts. The increase of communication, the exchange of ideas, and the depth of classroom discussions most likely enhanced their understanding of the topic addressed in class.

In conclusion, the findings from this study not only confirm the findings from the previous study, but also provide a basis for applying the "Design Team" approach and the "Blended Support for Learning" approach to prepare preservice teachers at PAAET for ICT integration. This is even more beneficial in relation to the e-Learning strategy of the Ministry of Education in Kuwait (2008), which adopts the blended learning approach for implementation in public schools. Therefore, it is beneficial that pre-service teachers experience and practice blended learning before graduation. Both ICT integration in education and the student-centred approach through working in DTs are new strategies for learning at the science teacher preparation program at PAAET. However, when the pre-service teachers are provided with appropriate support and help during the intervention process, they will achieve the desired goals and will be able to integrate ICT in their future teaching practice. 


\section{CHAPTER 5}

\section{Pre-service teachers' competencies for ICT integration: What do learning outcomes and self- reported data tell?*}

Since Technological Pedagogical Content Knowledge (TPACK) represents the knowledge needed by teachers to integrate ICT in their practice, it is really important to assess TPACK, ensure teachers' TPACK development. This study is concerned with assessing TPACK of pre-service teachers at the Public Authority of Applied Education and Training (PAAET) in Kuwait. The preservice teachers worked in Design Teams (DTs) and were provided by technological, pedagogical, and content support, to find an ICT-enhanced solution for an authentic educational problem which they could encounter in their teaching practice. Learning outcomes and self-reported measures were used to assess the development of the pre-service teachers' TPACK. The analysis of TPACK outcomes, on declarative, procedural, schematic, and strategic level, resulting from presentations, lesson plan design and development, products, and tests, showed that pre-service students had developed an understanding of TPACK and were able to integrate ICT in lesson plans and learning products through working in DTs. However, a closer inspection revealed no relationship between self-report findings and TPACK learning outcomes. This indicates that the students' own perception of their TPACK development was not necessarily aligned with the way they were able to integrate technology, pedagogy and content in practice. This unexpected finding is discussed in the context of valid and reliable measures of the TPACK construct.

Alayyar, G., Fisser, P., \& Voogt, J. (submitted). Pre-service teachers' competencies for ICT Integration: what do learning outcomes and self -report data tell? Journal of Educational Computing Research. 


\subsection{INTRODUCTION}

In 1986, Shulman presented his well-known work on Pedagogical Content Knowledge (PCK). PCK is a unique kind of knowledge that combines the knowledge of a teacher on what to teach (content) and how to teach (pedagogy). Shulman also included technology as a means to support education in his PCK framework but he 'did not explicitly discuss technology and its relationship to content, pedagogy, and learners, and thus PCK in its original form does not specifically explains how teachers use the affordances of technology to transform content and pedagogy for learners' (Angeli \& Valanides, 2009, p 156). However, with the rapid advances in technology, and the opportunities they provide for education, researchers in the field of educational technology and teacher education argued that Shulman's model should be extended by adding a technology component (Hughes, 2000, 2004; Niess, 2005, Pierson, 2001).

In 2005, Mishra and Koehler introduced Technological Pedagogical Content Knowledge (TPACK), which they defined as the ability to dynamically integrate content, pedagogy and technology in teaching practices (Koehler \& Mishra, 2005; 2008). The TPACK framework describes the kinds of knowledge needed by teachers for effective integration of technology in education. Next to the existing constructs of Pedagogical Knowledge (PK), Content Knowledge (CK), and Pedagogical Content Knowledge (PCK) and the added Technological Knowledge (TK), three more constructs emerged: Technological Content Knowledge (TCK), Technological Pedagogical Knowledge (TPK), and Technological Pedagogical Content Knowledge (TPACK). TPK is the knowledge about how teaching and learning can be changed through the use of technology, and how technology affects pedagogy. TCK encompasses knowledge about how technology and content are related. Teachers need to know how subject matter can be transformed by using technology i.e. understanding the influence of technology on the presentation of certain content. TPACK 'is different from the knowledge of its individual component concepts and their intersection. It arises instead from multiple interactions among content, pedagogical, technological and contextual knowledge' (Harris, Mishra \& Koehler, 2009, p.401). The TPACK framework helps teachers to decide on what kind of technology is suitable for teaching a specific content area, and whether this technology supports achieving specific learning outcomes or effectively improves students' learning processes. Besides understanding and developing knowledge related to TPACK, it is important for teachers to understand the "Context" in which technology will be integrated (Harris, Mishra \& Koehler, 2009). Koehler and Mishra (2008) stated that TPACK, like all types of 
knowledge is expressed in different ways and to different extents at different times with different students, and in differing contextual condition. Koehler and Mishra (2005) suggested that for developing TPACK, teachers work collaboratively to design a technological solution for an authentic problem. This approach was named the "Learning Technology by Design" approach.

The TPACK framework appears to be relatively simple and intuitive. However, putting TPACK in practice is more difficult than it appears at first sight. This article describes an intervention in which pre-service teachers developed their TPACK in Design Teams (see also Alayyar, Fisser, \& Voogt, submitted b). What they learned about TPACK was determined through a diversity of measures. This article describes the different methods and measures and discusses their contribution in understanding pre-service teachers' TPACK development.

\subsection{THEORETICAL FRAMEWORK}

Currently, educators and researchers around the world are using the TPACK framework to develop competencies needed for ICT integration in education. This necessitates the development of methods and procedures to assess the development of TPACK in (pre-service) teachers. Literature shows different ways of assessing TPACK. Shin, Mishra and Koehler (2011) for instance reviewed 66 publications that describe the implementation of different TPACK assessment measures and they report on five different kinds of measures and their reliability and validity. The TPACK measures that were identified were aligned with Gall, Gall and Borg's (2007) classification of ways of collecting research data. Table 5.1 gives a general overview of different instruments used for TPACK measurement. 
Table 5.1 Overview of different way of collecting data about TPACK from the literatures

\begin{tabular}{|c|c|c|}
\hline $\begin{array}{l}\text { Ways of } \\
\text { collecting data } \\
\text { (Gall, Gall \& } \\
\text { Borg, 2007) }\end{array}$ & Description & $\begin{array}{l}\text { Examples of TPACK } \\
\text { measurement from the literature }\end{array}$ \\
\hline $\begin{array}{l}\text { Self-report } \\
\text { measure* }\end{array}$ & $\begin{array}{l}\text { Asking participants to rate the } \\
\text { degree to which they agree or } \\
\text { disagree with the statement }\end{array}$ & $\begin{array}{l}\text { Koehler, Mishra \& Yahya } \\
\text { (2007) } \\
\text { - Archambault \& Crippen } \\
\text { (2009) } \\
\text { - Schmidt, Baran, Thompson, } \\
\text { Mishra Koehler, \& Shin } \\
\text { (2009)* } \\
\text { - Burgoyne, Graham \& } \\
\text { Sudweeks (2010) } \\
\text { - Zhou, Zhang, Li \& Zhao } \\
\text { (2010) } \\
\text { - Landry (2010) }\end{array}$ \\
\hline $\begin{array}{l}\text { Open-ended } \\
\text { questionnaires* }\end{array}$ & $\begin{array}{l}\text { Asking participants to record } \\
\text { written or typed responses to a set } \\
\text { of statements or questions } \\
\text { prepared by the researcher }\end{array}$ & $\begin{array}{l}\text { - } \text { Robertshaw \& Gillam (2010) } \\
\text { - Jaipal \& Figg (2010) } \\
\text { - } \text { Alayyar, Fisser \& Voogt } \\
\text { (submitted b) }\end{array}$ \\
\hline $\begin{array}{l}\text { Performance } \\
\text { assessments* }\end{array}$ & $\begin{array}{l}\text { Examining participant performance } \\
\text { to a given tasks or skills related to } \\
\text { TPACK }\end{array}$ & $\begin{array}{l}\text { - Koehler, Mishra \& Yahya } \\
\text { (2007) } \\
\text { - Suharwoto (2006) } \\
\text { - Harris, Grandgenett \& Hofer } \\
(2010)^{*} \\
\text { - Oster-Levinz \& Klieger (2010) }\end{array}$ \\
\hline $\begin{array}{l}\text { Interviews } \\
\text { (structured or } \\
\text { semi structured) }\end{array}$ & $\begin{array}{l}\text { A set of oral questions asked by the } \\
\text { interviewer and oral responses by } \\
\text { the interviewee. Interviews are } \\
\text { recorded, transcribed and } \\
\text { systematically analysed }\end{array}$ & $\begin{array}{l}\text { - Mishra, Peruski \& Koehler } \\
\text { (2007) } \\
\text { - Williams, Foulger \& Wetzel } \\
\text { (2010) }\end{array}$ \\
\hline Observations * & $\begin{array}{l}\text { Observing participants in } \\
\text { classroom or microteaching } \\
\text { sessions. Observation may video } \\
\text { recorded or field-note taking }\end{array}$ & $\begin{array}{l}\text { - Koehler, Mishra \& Yahya } \\
\text { (2007) } \\
\text { - Hofer, Grandgenett, Harris \& } \\
\text { Swan (2011) }\end{array}$ \\
\hline
\end{tabular}

Note: * Items that were adopted in the study described in this article.

According to Shin, Mishra and Koehler's review self-report measures and performance assessments were the most frequently used instruments while open-ended questionnaires were the least popular instrument for assessing someone's TPACK. 
Shin et al. (2011) made clear that many studies reported a combination of different measures to be able to draw conclusions from different perspectives. Doering, Scharber, Miller and Veletsianos (2009) also argue that TPACK needs to be assessed from different views to help in a holistic assessment of teaching with ICT. Also Alayyar, Fisser and Voogt (submitted, b) concluded that TPACK cannot be assessed by one single instrument, especially if this instrument is a self- reported measure. Although self-reported measures provide an important indicator about individual TPACK awareness (Kereluik, Casperson, \& Akcaoglu, 2010) it is worthwhile to note that this does not imply that teachers are able to integrate ICT, content and pedagogy in their classroom practice. Research has shown that the gains in teachers' self-assessed knowledge over a period of time are a reflection of their increased confidence regarding their ability to integrate technology rather than their actual practice shows (Harris, Grandgenett, Hofer, 2010; Lawless \& Pellegrino, 2007; Schrader \& Lawless, 2004). Also Archambault and Barnett (2010) state that 'although a survey methodology is appropriate when seeking to examine characteristics from a given population, it is not as accurate as actual observable behaviour' (Archambault \& Barnett, 2010, p.1661).

In an effort to uncover and understand more of the complexity inherent to the interdependence and situatedness of the TPACK construct, an attempt should be made to have a multiple method assessment of teachers' technology integration knowledge (Hofer, Grandgenett, Harris, \& Swan, 2011). The complexity mentioned by different researchers (Mishra \& Koehler, 2006; Borko, Whitcomb, \& Liston, 2008; Koehler \& Mishra, 2008; Mishra \& Koehler, 2007; Angeli \& Valanides, 2009) is due to inconsistencies between teachers' perceptions (i.e. what they think) and their classroom practices (i.e. what they do). For example Agyei and Voogt (2011) found that the teacher's self-reported perception of their TPACK was not aligned with the way they demonstrated TPACK in their lesson plan and their actual classroom practices: teachers in general tend to over-estimate their self-reported TPACK.

Niess (2008) proposes a classification to assess the work of pre-service teachers. She constructed a matrix to depict teachers' mental model on content while developing a lesson using technology, that could consist of declarative, procedural, schematic, and strategic technological pedagogical content knowledge. This classification was adopted from Shavelson, Ruiz-Primo, Li and Ayala (2003) to differentiate between different kinds of technology use. At the 
Declarative level technology is used to help students to identify targeted content (knowing what, for example by using a presentation). At the Procedural level teachers choose a technology to help their students to interpret data or information related to their content (knowing how to use the content knowledge, for example by using concept mapping software for certain topics such as environment pollution, or using spread sheets to conclude or estimate a relation between given factors). At the Schematic level the used technology helps the student to understand the complex relationship between concepts (knowing why, for example using simulations to explain day and night). And at the Strategic level technology is used to offer students the ability to synthesize the new knowledge by creating a product or performance that demonstrates their understanding (knowing when, where and how, for example by using podcast to publish audio or video files created by the students to describe concepts related to their content).

\subsection{PRE-SERVice TEACHERS' DEVElopMent OF TPACK THROUGH Design TEAMS}

The pre-service science teachers $(\mathrm{N}=78)$ who participated in this study, were from the Public Authority of Applied Education and Training (PAAET) in Kuwait. They had registered for the 'Educational Seminar' course which is accompanied with an in-school field training in the final semester of the educational program. In the spring semester of 2010 the course aimed to develop pre-service teachers' TPACK through working in Design Teams (DTs). The effectiveness of DTs for developing TPACK was initially demonstrated in studies by Koehler and Mishra (2005) and confirmed by a previous study (Alayyar, Fisser \& Voogt, submitted b). In the current study the same procedure was followed. In the DTs the pre-service science teachers had to develop an ICT solution for a real educational problem. The course lasted for 12 weeks, two hours per week. The Educational Seminar Course has two instructors. One instructor (the researcher) acted as technology expert and as a content knowledge expert for science teaching. The other instructor was a pedagogical expert and the content expert for mathematics.

To introduce the pre-service students to TPACK and to form the DTs a workshop was organized during the first four weeks. During the last day of the workshop students were asked to form a DT of three to four members. The DTs had to 
identify one topic, to be taught using ICT. In the fifth week the teams were asked to present their problem and the possible ICT solution(s) for their peers and the experts. During this presentation, the experts and peers reflected on the problem, the suggested ICT-tool, and the suggested pedagogy. From the fifth to the tenth week, DTs designed their ICT-enhanced solution for the addressed problem and were supported by two options: human support or blended support. In the eleventh week, the teams were asked to present their solution to the experts and their peers. The teams were also asked to submit a CD-ROM containing their product with a paper describing their lesson plan and their ICT integration plan that explains the role of the teacher and the student. The products of both groups were evaluated by the two instructors. In the last week students were asked to complete different measures to determine their understanding of TPACK.

\subsection{PROBLEM STATEMENT AND RESEARCH QUESTIONS}

This study aimed to investigate the effectiveness of various measures associated with assessing pre-service teachers' TPACK: Explaining TPACK, Presenting TPACK, Defining TPACK, Reflecting on TPACK, Designing TPACK lesson plan and product, and ICT skills). Therefore, the following research questions were applied:

RQ1: What TPACK competencies expressed in learning outcomes do the pre-service teachers demonstrate after working in Design Teams on ICT integration and how are these outcomes related?

RQ2: How are the TPACK learning outcomes of the pre-service teachers related to their self-reported TPACK?

\subsection{METHOD}

\subsubsection{Participants}

All the 78 pre-service teacher participants of this study were female with an average age of 23 years. Some of the participants had science as their major specialization and math as minor. Others had math as major and science as minor specialization. Almost all the participants had a computer at home and about $96 \%$ had an internet connection at home. 


\subsubsection{Instruments}

Eight different instruments were used in this study to assess the learning outcomes and the TPACK development of the pre-service teachers after they had worked in DTs to develop an ICT solution for an educational problem. Table 5.2 shows a general overview of the different instruments used in this intervention with their purpose and source of data.

Table 5.2 Overview of the different instruments used in this study

\begin{tabular}{|c|c|c|c|c|c|}
\hline \multirow[b]{2}{*}{ Instrument } & \multirow[b]{2}{*}{ Purpose } & \multirow[b]{2}{*}{$\begin{array}{l}\text { Confidence/ } \\
\text { Knowledge }^{*}\end{array}$} & \multirow[b]{2}{*}{$\begin{array}{l}\text { Measurement } \\
\text { type }\end{array}$} & \multicolumn{2}{|c|}{ TPACK data } \\
\hline & & & & Source ${ }^{* *}$ & $\begin{array}{l}\text { Observable } \\
\text { or self- } \\
\text { reported }\end{array}$ \\
\hline $\begin{array}{l}\text { Presentation } \\
\text { Rubric }\end{array}$ & $\begin{array}{l}\text { Assess the ability to } \\
\text { present the idea behind } \\
\text { the final product for } \\
\text { experts and peers }\end{array}$ & $\begin{array}{l}\text { Confidence/ } \\
\text { Schematic }\end{array}$ & Observation & I & Observable \\
\hline $\begin{array}{l}\text { Explanation } \\
\text { Checklist }\end{array}$ & $\begin{array}{l}\text { Assess the ability to argue } \\
\text { and explain the rationale } \\
\text { behind the chosen design, } \\
\text { ICT, pedagogy, \& content }\end{array}$ & Schematic & Observation & I & Observable \\
\hline $\begin{array}{l}\text { TPACK } \\
\text { Definition } \\
\text { Rubric }\end{array}$ & $\begin{array}{l}\text { Assess the ability to } \\
\text { define TPACK concepts }\end{array}$ & Declarative & $\begin{array}{l}\text { Open ended } \\
\text { questionnaire }\end{array}$ & I & Observable \\
\hline $\begin{array}{l}\text { TPACK } \\
\text { Reflection } \\
\text { Rubric }\end{array}$ & $\begin{array}{l}\text { Assess the ability to apply } \\
\text { TPACK in real teaching } \\
\text { practice }\end{array}$ & Strategic & $\begin{array}{l}\text { Open ended } \\
\text { questionnaire }\end{array}$ & I & Observable \\
\hline $\begin{array}{l}\text { Lesson Plan } \\
\text { Rubric }\end{array}$ & $\begin{array}{l}\text { Assess the quality of ICT } \\
\text { integration lesson plan }\end{array}$ & Strategic & $\begin{array}{l}\text { Performance } \\
\text { assessment }\end{array}$ & $\mathbf{T}$ & Observable \\
\hline $\begin{array}{l}\text { Product } \\
\text { Rubric }\end{array}$ & $\begin{array}{l}\text { Assess the quality of ICT } \\
\text { integration in the product }\end{array}$ & Strategic & $\begin{array}{l}\text { Performance } \\
\text { assessment }\end{array}$ & $\mathrm{T}$ & Observable \\
\hline ICT skill test & Assess the ICT skills & Procedu-ral & $\begin{array}{l}\text { Performance } \\
\text { assessment }\end{array}$ & I & Observable \\
\hline $\begin{array}{l}\text { TPACK } \\
\text { survey }\end{array}$ & $\begin{array}{l}\text { Assess the self-reported } \\
\text { TPACK }\end{array}$ & Confiden-ce & Survey & I & $\begin{array}{l}\text { Self- } \\
\text { reported }\end{array}$ \\
\hline
\end{tabular}

Note: * based on Niess (2008); ** I:individual score, T:team score.

\section{Presentation rubric}

At the end of the course students were asked to present their product to their peers and the instructors. During the presentation the students had to state and clarify the idea behind choosing their topic (e.g. whether it is related to students' misconception, an abstract concept, etc.), the objective of the lesson, the added value of the ICT tools that were selected, how this aids in solving the 
problem, and the reasons behind using a specific pedagogy in combination with the ICT tools. Next to this they had to present their ideas about screen design (layout, icons, branching and colours).

A presentation rubric was developed by the researcher to assess the presentation of each team member. This instrument addresses four main scales with a maximum score of six points. Three points could be assigned for the accuracy of the given information in relation to content, ICT and pedagogy. Next to this one point for each of the following aspects could be assigned: a) self-confidence, b) eye contact and directing the talk to the audience, and c) verbal techniques (i.e. sound tone and clarity). During the presentation the two instructors evaluated the students by using the presentation rubric. If the scores were differently assessed by the two assessors the mean of the two scores was calculated. Cohen's kappa was calculated to assess the variation of the two independent evaluators that rated the student's presentation, which was $(\kappa=0$. 93) indicating almost perfect agreement.

\section{Explanation checklist}

After the presentation of the product questions were asked by the peers and the instructors about the rationale behind the students' choice of ICT, pedagogy, content and the design principles for the multimedia products. some of the questions commonly asked were, 'How did you met objective $(\mathrm{x})$ as stated in your lesson plan in your final product?', 'How did your choice of ICT/ Pedagogy help in solving the related problem?', 'What is the added value of using a sound effect in this screen?', and 'How did you create this animation?'. The students 'answers were assessed by the instructors. Each student had three minutes to answer the questions (with a minimum of two questions). Their answers were scored by the instructors during the class using the checklist. If there was a difference in scoring the mean was calculated. The maximum score for this instrument was 4. Using Cohen's kappa the variation of the two independent evaluators that rated the student's explanation was calculated. The score $(\mathrm{K}=0.93)$ obtained reflected a high or almost perfect agreement.

\section{TPACK definition rubric}

At the end of the course all students were asked to individually write an extended definition of TPACK. This question was meant to assess the preservice understanding of the TPACK framework. The answers from this question were analysed by the researcher using the TPACK definition rubric, 
developed by the researcher. The maximum score for the definition question was 3. Table 5.3 shows the TPACK definition rubric.

Table 5.3 The TPACK definition rubric

\begin{tabular}{|c|c|c|c|c|}
\hline Points & 3 & 2 & 1 & 0 \\
\hline $\begin{array}{l}\text { Definition of } \\
\text { TPACK }\end{array}$ & $\begin{array}{l}\text { PK, TK, CK interact and } \\
\text { intertwined (PCK,TPK, TCK } \\
\mathcal{E} \text { TPACK) together in state } \\
\text { of equilibrium within the } \\
\text { context }\end{array}$ & $\begin{array}{l}\text { PK, TK, CK } \\
\text { interact and } \\
\text { intertwined }\end{array}$ & $\begin{array}{l}\text { PK, TK, } \\
\text { CK } \\
\text { interact } \\
\text { with each } \\
\text { other }\end{array}$ & $\begin{array}{l}\mathrm{PK}, \mathrm{TK} \text { and } \\
\mathrm{CK} \text { (or no } \\
\text { explanation } \\
\text { at all) }\end{array}$ \\
\hline
\end{tabular}

An example of an answer of a student to this question with a high score (3) is "TPACK is a framework to describe the knowledge needed by a teacher to teach effectively with ICT. It is the result of the combination and the interaction between TK, PK, and CK, to produce PCK, TCK, TPK, and TPACK. Teachers who have TPACK, can choose ICT that has an added value for her topic and or teaching method. A change in one domain (CK, $P K$, and TK) leads to a change in the others for a better fit together. A teacher with TPACK always thinks and rethinks the domains and the environment that she teaches in". An example of a student with a medium score (2) is "TPACK is the knowledge needed by teacher to teach with technology it is build up from TK, PK and $C K$ " and an example of an answer with a low score (1) is "TPACK exist when TK is combined with PK and CK".

TPACK reflection rubric

At the end of the course all students were asked to individually write an example of a teaching task in which they effectively combined the content of a lesson with a specific teaching approach supported by ICT in a classroom situation. They had to include the following in their answer: a) a description of the content, b) the objectives, c) the target group, d) the teaching approach(s), e) the ICT tools, and, f) the roles of the teacher and the students in relation to ICT. With this reflective assignment the pre-service teachers' understanding of TPACK and whether they could relate the concept of TPACK to their own teaching experience during their in-school training could be assessed. The answers from this question were analysed by the researcher by using the TPACK reflection rubric, developed by the researcher and shown in Table 5.4. The maximum score for the reflection question was 15 . 
Table 5.4 TPACK reflection rubric

\begin{tabular}{|c|c|c|c|c|}
\hline \multirow[b]{2}{*}{ TPACK Example } & \multicolumn{4}{|c|}{ ICT (TK) } \\
\hline & 3 & 2 & 1 & 0 \\
\hline $\begin{array}{l}\text { Topic/objective } \\
\text { (CK) }\end{array}$ & $\begin{array}{l}\text { ICT tool } \\
\text { selected are } \\
\text { strongly } \\
\text { aligned with } \\
\text { the Content } \\
\text { and all the } \\
\text { lesson } \\
\text { objectives }\end{array}$ & $\begin{array}{l}\text { ICT tool } \\
\text { selected are } \\
\text { aligned with } \\
\text { the content } \\
\text { and at least } \\
\text { one objectives } \\
\text { of the lesson }\end{array}$ & $\begin{array}{l}\text { ICT tool } \\
\text { selected are } \\
\text { partially } \\
\text { aligned with } \\
\text { the content and } \\
\text { at least one } \\
\text { objectives of } \\
\text { the lesson }\end{array}$ & $\begin{array}{l}\text { ICT tool } \\
\text { selected are no } \\
\text { aligned with } \\
\text { the content } \\
\text { and the lesson } \\
\text { objectives }\end{array}$ \\
\hline $\begin{array}{l}\text { Target } \\
\text { (Context) }\end{array}$ & $\begin{array}{l}\text { ICT tool } \\
\text { selected are } \\
\text { suitable for } \\
\text { the target } \\
\text { group and } \\
\text { context }\end{array}$ & $\begin{array}{l}\text { ICT tool } \\
\text { selected need } \\
\text { an effort to } \\
\text { support target } \\
\text { student to } \\
\text { work }\end{array}$ & $\begin{array}{l}\text { ICT tool } \\
\text { selected need } \\
\text { extra support } \\
\text { from both } \\
\text { parents and } \\
\text { instructors for } \\
\text { target group to } \\
\text { work on }\end{array}$ & $\begin{array}{l}\text { ICT selected } \\
\text { tool s are not } \\
\text { suitable for the } \\
\text { target group }\end{array}$ \\
\hline $\begin{array}{l}\text { Teaching strategy } \\
\text { (PK) }\end{array}$ & $\begin{array}{l}\text { ICT used } \\
\text { optimally } \\
\text { supports } \\
\text { teaching } \\
\text { strategy }\end{array}$ & $\begin{array}{l}\text { ICT used } \\
\text { supports } \\
\text { teaching } \\
\text { strategy }\end{array}$ & $\begin{array}{l}\text { ICT used } \\
\text { minimally } \\
\text { supports } \\
\text { teaching } \\
\text { strategy }\end{array}$ & $\begin{array}{l}\text { ICT used does } \\
\text { not supports } \\
\text { teaching } \\
\text { strategy }\end{array}$ \\
\hline $\begin{array}{l}\text { Overall fit } \\
\text { (CK, PK \& } \\
\text { Context) }\end{array}$ & $\begin{array}{l}\text { ICT tool, CK, } \\
\text { Context and } \\
\text { PK fit } \\
\text { strongly } \\
\text { together }\end{array}$ & $\begin{array}{l}\text { ICT tool, CK, } \\
\text { Context and } \\
\text { PK fit } \\
\text { together }\end{array}$ & $\begin{array}{l}\text { ICT tool, CK, } \\
\text { Context and PK } \\
\text { somewhat fit } \\
\text { together }\end{array}$ & $\begin{array}{l}\text { ICT tool, CK, } \\
\text { Context and } \\
\text { PK do not fit } \\
\text { together }\end{array}$ \\
\hline $\begin{array}{l}\text { Student role with } \\
\text { ICT }\end{array}$ & $\begin{array}{l}\text { Yes } \\
\text { - Highly } \\
\text { active }\end{array}$ & - Active & - Partially & $\begin{array}{l}\text { No } \\
\text { - Not active }\end{array}$ \\
\hline
\end{tabular}

\section{TPACK lesson plan rubric}

The TPACK integration rubric (Harris, Grandgenett, \& Hofer, 2010) is a reliable and valid measure to analyse lesson plans. It was adopted to analyse the lesson plans of the DTs.

The lesson plan rubric consists of four main criteria: a) curriculum goals and technologies (to assess whether the selected ICT tool fits the curriculum goals), b) instructional strategies and technologies (to assess if the used ICT tool is supporting the teaching and learning process), c) technology selection (to assess 
whether the selected ICT tool is compatible with and fits the curriculum goals and instructional strategies), and d) fit, (to assess how the content, the pedagogy and the ICT tool fit together).

The lesson plans were assessed by the instructors. The maximum score of the TPACK lesson plan rubric was 16 points with one to four points for each criterion. The lesson plans were analysed by the instructors by using the lesson plan rubric, and if there was a difference in scoring the mean was calculated. Cohen's kappa was calculated to assess the variation of the two independent evaluators that rate the product, which was almost perfect agreement $(\mathrm{K}=0.93)$.

\section{TPACK product rubric}

The product rubric is adapted from the Multimedia Mania 2004 - Judges' Rubric (ISTE's HyperSIG, 2004) to evaluate the DTs final product and it consisted of 15 items and each item can be rated from 0 to 4 with a maximum score of 60 . This instrument evaluates the product in relation to technical problems, navigation, spelling and grammatical errors, completion, design, use of enhancement such as graphics and sound, organization, branching, citing resources, originality, curriculum alignment and meeting the objectives, depth and breadth of the project content, subject knowledge (CK) and teamwork. The product was evaluated by the instructors, and if there was a difference in scoring the mean was calculated. Cohen's kappa was calculated to assess the variation of the two independent evaluators that rate the product, which was $(\mathrm{k}=0.93)$, indicating almost perfect agreement.

\section{ICT skill test}

The reason behind assessing the ICT skills of the pre-service teachers is twofold: a) since the main objective of any TPACK related intervention is to prepare teachers to integrate ICT effectively in their daily classroom practices, this implies that the acquisition or the development of TPACK will lead to a growth in skills related to ICT. This in turn means that the assessment of ICT-related skills can be a good indicator of TPACK development and the success of TPACK related intervention.

b) Second, the TK statements in the TPACK survey are assessing self confidence in TK beside that it assesses TK as a declarative kind of knowledge (Alayyar, Fisser, \& Voogt, submitted b). And in this study we need to assess not only the confidence toward ICT skills, but also the actual practical skills that students possess after the TPACK related intervention. 
Therefore at the end of the intervention the students were asked to individually answer the ICT skill test, which is a 20 mark performance attainment test developed by the researcher to assess the students' level of ICT skills (see Alayyar, Fisser \& Voogt; in press). The instrument consists of six questions which assess different skills such as knowing how to operate and deal with the Windows operating system and proficiency in working with the Microsoft Office suite, the internet, Adobe Photoshop, and multimedia editing software. The test was reviewed by two educational technology experts and the reliability of the test was $\alpha=.85$.

\section{TPACK survey}

The TPACK survey is a reliable and valid self-report instrument (Schmidt, Baran, Thompson, Koehler, Shin \& Mishra, 2009) to measure someone's TPACK. It was used at the beginning and the end of the intervention to assess the individual student's perceived TPACK. This instrument uses a five-point Likert scale ranging from strongly disagree to strongly agree. The items included in this instrument measure pre-service teachers' self-assessments of their perception of the different TPACK domains. Some examples of statements in each domain of TPACK are given in Table 5.5. Schmidt et al (2009) reported that the TPACK survey exhibited strong internal consistency reliability and the internal consistency reliability ranged from .75 to .92 for the seven TPACK subscales.

\section{Table 5.5 Example of TPACK survey statements for each domain}

\begin{tabular}{|c|c|}
\hline Domains & Exemplary items \\
\hline TK & $\begin{array}{l}\text { - I know how to solve my own technical problems } \\
\text { - I know about a lot of different technologies. }\end{array}$ \\
\hline CK & $\begin{array}{l}\text { - I can use a scientific way of thinking. } \\
\text { - I have sufficient knowledge about science. }\end{array}$ \\
\hline PK & $\begin{array}{l}\text { - I know how to assess student performance in a classroom. } \\
\text { - I can adapt my teaching style to different learners. }\end{array}$ \\
\hline PCK & $\begin{array}{l}\text { I know how to select effective teaching approaches to guide student } \\
\text { thinking and learning in science. }\end{array}$ \\
\hline TCK & $\begin{array}{l}\text { - I know about technologies that I can use for understanding and doing } \\
\text { science }\end{array}$ \\
\hline TPK & $\begin{array}{l}\text { - I can choose technologies that enhance the teaching approaches for a } \\
\text { lesson. } \\
\text { - I am thinking critically about how to use technology in my classroom. }\end{array}$ \\
\hline TPACK & $\begin{array}{l}\text { - I can choose technologies that enhance the content for a lesson. } \\
\text { - I can teach lessons that appropriately combine science, technologies, and } \\
\text { teaching approaches. }\end{array}$ \\
\hline
\end{tabular}


The TPACK survey has been translated to the Arabic language and reviewed by two educational technology experts. The Arabic translated instrument had a reliability of Cronbach's alpha between .72 and .86 on the different domains related to TPACK framework of the instrument.

\subsubsection{Data analysis}

The Cohen's Kappa coefficient $(\mathrm{k})$ was calculated to estimate the degree of agreement among the ratters of the instruments. Landis and Koch (1977) proposed a schema for interpreting $\mathrm{k}$ values: $\mathrm{k}<0$ for poor agreement; 0 to .20 slight agreement, $\mathrm{k}=.21$ to $.40 \mathrm{a}$ fair agreement, $\mathrm{k}=0.41$ to .60 a moderate agreement; $\mathrm{k}=.61$ to .80 a substantial agreement; and $\mathrm{k}=.81$ to 1.00 a perfect agreement.

Means and standard deviations of the student outcomes were calculated. To compare the difference between pre- and post-measures the t-test was used. If the result of the t-test was significant, the effect size (Cohen's d) was calculated to get an indication of the magnitude of the effect. Cohen (1988) provided tentative benchmarks for the interpretation of effect sizes. He considers $d=0.2$ a small, $d=$ 0.5 a medium and $d=0.8$ a large effect size. Pearson correlation $(r)$ was used to assess the correlation between the different measures. The correlation coefficients of $.10, .30$ and .50 , irrespective of the sign, are interpreted as small, medium and large coefficient respectively (Green \& Salkind, 2008).

\subsection{RESULTS}

\subsubsection{Evaluating the products}

The DTs ICT-enhanced lesson (ICT product and lesson plan) were evaluated by using the TPACK lesson plan rubric and the TPACK product rubric. To give some examples of the final products of the students and their TPACK-related content, Table 5.6 presents six examples of the DTs ICT-enhanced lessons. The products are ranked according to their scores into three main groups, which were categorized as very good, good, and satisfactory, two examples are given for each category. In the table the products of the students are described by presenting the title of the product, a short description, the content that is included in the product and the added value of ICT to the content. 
Table 5.6 Summary of different examples of ICT-enhanced lesson with the added value of ICT to content (TCK)

\begin{tabular}{|c|c|c|c|c|}
\hline $\begin{array}{l}\text { Grade } \\
\text { level }\end{array}$ & $\begin{array}{l}\text { Title } \\
\text { (Description) }\end{array}$ & $\begin{array}{l}\text { Content (supported } \\
\text { by ICT) }\end{array}$ & $\begin{array}{l}\text { Added value of ICT to } \\
\text { content } \\
\text { (TCK) }\end{array}$ & Ranking \\
\hline $\begin{array}{l}\text { Grade } \\
3\end{array}$ & $\begin{array}{l}\text { 2D and 3D shapes } \\
\text { What is: Area, plane, } \\
\text { 2Dshapes, 3D shapes? } \\
\text { How many angles, } \\
\text { sides, and faces 3D } \\
\text { shapes have? }\end{array}$ & $\begin{array}{l}\text { Learn facts (presen- } \\
\text { tation, digital story) } \\
\text { Understand concepts } \\
\text { (presentation/ digital } \\
\text { story) } \\
\text { ICT skill acquisition } \\
\text { (digital camera, } \\
\text { blogging, word } \\
\text { processing, email) }\end{array}$ & $\begin{array}{l}\text { Better understanding of } \\
\text { the content through } \\
\text { connecting familiar to new } \\
\text { forms of knowledge. } \\
\text { (connecting famous building } \\
\text { over the world to 3D,2D } \\
\text { shapes, Angles, Plane, and } \\
\text { edge) by converting buil- } \\
\text { ding to wireframe without } \\
\text { any texture and highlight } \\
\text { new concepts }\end{array}$ & Very good \\
\hline $\begin{array}{l}\text { Grade } \\
4\end{array}$ & $\begin{array}{l}\text { Work and simple } \\
\text { machines } \\
\text { What is force and } \\
\text { work? Lever, wheel, } \\
\text { screw, inclined plane, } \\
\text { gear }\end{array}$ & $\begin{array}{l}\text { Learn facts (presen- } \\
\text { tation) } \\
\text { Understand concepts } \\
\text { (presentation/ digital } \\
\text { story with a video clip) } \\
\text { ICT skill acquisition } \\
\text { (WWW, digital } \\
\text { camera, word } \\
\text { processsing, } \\
\text { e-mail or blog) }\end{array}$ & $\begin{array}{l}\text { Better understanding of } \\
\text { the content through } \\
\text { connecting familiar and } \\
\text { new forms of knowledge. } \\
\text { Through visualization. } \\
\text { Showing how simple } \\
\text { machines work together to } \\
\text { form more complex } \\
\text { machine used in daily } \\
\text { lives. }\end{array}$ & Very good \\
\hline $\begin{array}{l}\text { Grade } \\
3\end{array}$ & $\begin{array}{l}\text { How is sound } \\
\text { produced? (vibration, } \\
\text { waves) } \\
\text {-loud and quiet sounds } \\
\text { are produced by big or } \\
\text { small vibrations } \\
\text { - high or low pitched } \\
\text { notes are produced by } \\
\text { fast or slow vibrations. }\end{array}$ & $\begin{array}{l}\text { Learn facts (presen- } \\
\text { tation) } \\
\text { Understand concepts } \\
\text { (presentation/ digital } \\
\text { story) } \\
\text { ICT skill acquisition } \\
\text { (sound recording, } \\
\text { editing \& publishing, } \\
\text { word processing) }\end{array}$ & $\begin{array}{l}\text { Better understanding of } \\
\text { the content through } \\
\text { visualization of abstract } \\
\text { concepts, such as vibration } \\
\text { of loud and quite or low and } \\
\text { high sounds. } \\
\text { Gaining experience in } \\
\text { using different ICT } \\
\text { application }\end{array}$ & Good \\
\hline $\begin{array}{l}\text { Grade } \\
4\end{array}$ & $\begin{array}{l}\text { How do animals } \\
\text { grow and change? } \\
\text { How do animal babies } \\
\text { grow to look like their } \\
\text { parents }\end{array}$ & $\begin{array}{l}\text { Learn facts (presen- } \\
\text { tation) } \\
\text { Understand concepts } \\
\text { (presentation/video clip } \\
\text { captured by the teacher) } \\
\text { Understand pro- } \\
\text { cesses (video clips, } \\
\text { MP3 song of chicks } \\
\text { and eggs) } \\
\text { ICT skill acquisition } \\
\text { (WWW, word } \\
\text { processing, photo } \\
\text { editor) }\end{array}$ & $\begin{array}{l}\text { Better understanding of } \\
\text { the content by simulating } \\
\text { and fasten up the process } \\
\text { of growth and listening to } \\
\text { a MP3 song. } \\
\text { Avoiding ethical, moral } \\
\text { and emotional problems } \\
\text { (killing the chicken embryo } \\
\text { inside the egg) by using the } \\
\text { internet and video to find } \\
\text { information about the } \\
\text { stages within the egg }\end{array}$ & Good \\
\hline
\end{tabular}


Table 5.6 Summary of different examples of ICT-enhanced lesson with the added value of ICT to content (TCK) (Continued)

\begin{tabular}{|l|l|l|l|l|}
$\begin{array}{l}\text { Grade } \\
\text { level }\end{array}$ & $\begin{array}{l}\text { Title } \\
\text { (Description) }\end{array}$ & $\begin{array}{l}\text { Content (supported } \\
\text { by ICT) }\end{array}$ & $\begin{array}{l}\text { Added value of ICT to } \\
\text { content } \\
\text { (TCK) }\end{array}$ & Ranking \\
\hline $\begin{array}{l}\text { Grade } \\
2\end{array}$ & $\begin{array}{l}\text { Solving problems: } \\
\text { problems that contains } \\
\text { before, after, first, and } \\
\text { last }\end{array}$ & $\begin{array}{l}\text { Understand con- } \\
\text { cepts (presentation) } \\
\text { ICT skill acquisition } \\
\text { (word process) }\end{array}$ & $\begin{array}{l}\text { Animated character } \\
\text { motivate the student to } \\
\text { learn the concepts }\end{array}$ & Satisfactory \\
\hline $\begin{array}{l}\text { Grade } \\
3\end{array}$ & $\begin{array}{l}\text { Flip, slide, turn } \\
\text { Reflection, translation, } \\
\text { and rotation of objects }\end{array}$ & $\begin{array}{l}\text { Understand } \\
\text { concepts (presen- } \\
\text { tation) }\end{array}$ & $\begin{array}{l}\text { Animated character } \\
\text { enhance understanding of } \\
\text { the concept especially } \\
\text { differentiating between } \\
\text { flip and turn }\end{array}$ & Satisfactory \\
\hline
\end{tabular}

The teams were able to choose a topic related to the science or the mathematics curriculum at the primary school and they tried to find a suitable ICT tool that added value to teaching the chosen topic. Approximately all the pre-service teachers used a presentation, a digital story, a video clip or an animation to present the new content to aid in understanding the new concepts. The technology used solved the problem of the chosen topic by visualizing abstract concepts (e.g. sound waves), by speeding up some processes to enable students to observe the process during class time (e.g. the development of a chick inside an egg), solving ethical problems related to dissecting or killing animals, and for student to explore, or enhance memorization of certain steps or stages (e.g. a MP3 song used to describe the stages of chick development).

Table 5.7 presents the same examples, but this time related to the activities of the teachers and the students and the added value of ICT to the pedagogical approach. 
Table 5.7 Description of different examples of ICT-enhanced lesson with the added value of ICT to pedagogy (TPK)

\begin{tabular}{|c|c|c|c|c|}
\hline $\begin{array}{l}\text { Title } \\
\text { Grade } \\
\text { level }\end{array}$ & $\begin{array}{l}\text { Teacher } \\
\text { activities* }\end{array}$ & $\begin{array}{l}\text { Student } \\
\text { activities* }\end{array}$ & $\begin{array}{l}\text { Added value of ICT to } \\
\text { pedagogy (TPK) }\end{array}$ & $\begin{array}{l}\text { Ran- } \\
\text { king }\end{array}$ \\
\hline $\begin{array}{l}\text { 2D and 3D } \\
\text { shapes } \\
\text { Grade } 3\end{array}$ & $\begin{array}{l}\text { Lecture (presenta- } \\
\text { tion, } 3 D \text { digital } \\
\text { story) } \\
\text { Monitor/assess } \\
\text { students' } \\
\text { performance } \\
\text { (online questions, } \\
\text { digital photo and } \\
\text { reflection on the } \\
\text { blog/Google Docs) }\end{array}$ & $\begin{array}{l}\text { Manipulate/inter } \\
\text { prets data (digital } \\
\text { camera) } \\
\text { Publish or present } \\
\text { data (blog/Google } \\
\text { Docs) } \\
\text { Assess own/peer } \\
\text { performance } \\
\text { (blog/Google Docs) } \\
\text { Collaboration in } \\
\text { teams }\end{array}$ & $\begin{array}{l}\text { The lecture-based activities } \\
\text { activate students prior } \\
\text { knowledge and connect it to } \\
\text { the new concepts and motivate } \\
\text { students to learn } \\
\text { The team collaboration of the } \\
\text { students while using ICT tools } \\
\text { and application motivate and } \\
\text { enhances understanding of the } \\
\text { students. }\end{array}$ & $\begin{array}{l}\text { Very } \\
\text { good }\end{array}$ \\
\hline $\begin{array}{l}\text { Work and } \\
\text { simple } \\
\text { machines } \\
\text { Grade } 4\end{array}$ & $\begin{array}{l}\text { Lecture (presenta- } \\
\text { tion with digital } \\
\text { story, video clip) } \\
\text { Advise/guide } \\
\text { (blog and email) } \\
\text { Monitor/asses } \\
\text { students' perfor- } \\
\text { mance (online } \\
\text { questions, blog) }\end{array}$ & $\begin{array}{l}\text { Search for infor- } \\
\text { mation (WWW, } \\
\text { Digital camera) } \\
\text { Publish/present } \\
\text { data (blog) } \\
\text { Assess own/peers } \\
\text { understanding } \\
\text { (blog) } \\
\text { Collaboration in } \\
\text { teams }\end{array}$ & $\begin{array}{l}\text { The lecture-based activities } \\
\text { activate students' prior } \\
\text { knowledge and gives new } \\
\text { knowledge. } \\
\text { Animated simples tools grab } \\
\text { students attention and enhance } \\
\text { understanding } \\
\text { The team collaboration of the } \\
\text { students while using ICT tools } \\
\text { (camera) and searching the } \\
\text { WWW enhance understanding } \\
\text { of the concepts. }\end{array}$ & $\begin{array}{l}\text { Very } \\
\text { good }\end{array}$ \\
\hline $\begin{array}{l}\text { How is } \\
\text { sound } \\
\text { produced? } \\
\text { Grade } 3\end{array}$ & $\begin{array}{l}\text { Lecture } \\
\text { (presentation, } \\
\text { digital story) } \\
\text { Monitor/asses } \\
\text { students' perfor- } \\
\text { mance (online } \\
\text { question, MP3 } \\
\text { sound clip) }\end{array}$ & $\begin{array}{l}\text { Search for infor- } \\
\text { mation (WWW) } \\
\text { Manipulate/inter } \\
\text { prets data (logging } \\
\text { by microphone) } \\
\text { Publish/present } \\
\text { data (MP3 clips) } \\
\text { Collaboration in } \\
\text { teams. }\end{array}$ & $\begin{array}{l}\text { The lecture-based activity } \\
\text { activates students' prior } \\
\text { knowledge and gives new } \\
\text { knowledge } \\
\text { The team collaboration of the } \\
\text { students while using ICT } \\
\text { applications stimulates } \\
\text { creativity }\end{array}$ & Good \\
\hline $\begin{array}{l}\text { How do } \\
\text { animals } \\
\text { grow and } \\
\text { change? } \\
\text { Grade } 4\end{array}$ & $\begin{array}{l}\text { Lecture } \\
\text { (presentation with } \\
\text { video clip) } \\
\text { Monitor/asses } \\
\text { students' perfor- } \\
\text { mance (online } \\
\text { question, Sound } \\
\text { clip, poster). } \\
\text { Collaborate with } \\
\text { students (product } \\
\text { production) }\end{array}$ & $\begin{array}{l}\text { Search for infor- } \\
\text { mation_(WWW) } \\
\text { Design/Create } \\
\text { product (poster } \mathcal{E} \\
\text { story) } \\
\text { Collaboration in } \\
\text { teams. }\end{array}$ & $\begin{array}{l}\text { The lecture-based activity } \\
\text { activates students' prior } \\
\text { knowledge, gives new } \\
\text { knowledge, and solve } \\
\text { emotional and ethical problem. } \\
\text { The team collaboration of the } \\
\text { students while using ICT } \\
\text { applications stimulates } \\
\text { creativity, learning from peers, } \\
\text { improve searching for } \\
\text { information. }\end{array}$ & Good \\
\hline
\end{tabular}


Table 5.7 Description of different examples of ICT-enhanced lesson with the added value of ICT to pedagogy (TPK)

\begin{tabular}{|c|c|c|c|c|}
\hline $\begin{array}{l}\text { Title } \\
\text { Grade } \\
\text { level }\end{array}$ & $\begin{array}{l}\text { Teacher } \\
\text { activities* }\end{array}$ & $\begin{array}{l}\text { Student } \\
\text { activities* }\end{array}$ & $\begin{array}{l}\text { Added value of ICT to } \\
\text { pedagogy (TPK) }\end{array}$ & $\begin{array}{l}\text { Ran- } \\
\text { king }\end{array}$ \\
\hline $\begin{array}{l}\text { Before, } \\
\text { after, first, } \\
\text { and last } \\
\text { Grade } 2\end{array}$ & $\begin{array}{l}\text { Lecture (presen- } \\
\text { tation) } \\
\text { Monitor/asses } \\
\text { students' perfor- } \\
\text { mance online } \\
\text { question, word } \\
\text { docs about what } \\
\text { did you do today)) }\end{array}$ & $\begin{array}{l}\text { Design/create } \\
\text { product (list of } \\
\text { tasks and time in } \\
\text { word). }\end{array}$ & $\begin{array}{l}\text { The lecture-based activity links } \\
\text { everyday life to the new } \\
\text { knowledge }\end{array}$ & $\begin{array}{l}\text { Satisfac- } \\
\text { tory }\end{array}$ \\
\hline $\begin{array}{l}\text { Flip, slide, } \\
\text { turn } \\
\text { Grade } 3\end{array}$ & $\begin{array}{l}\text { Lecture(presentat } \\
\text { ion) } \\
\text { Monitor/asses } \\
\text { students' perfor- } \\
\text { mance online } \\
\text { question, Word } \\
\text { docs of the } \\
\text { manipulated } \\
\text { picture with } \\
\text { written comment) }\end{array}$ & $\begin{array}{l}\text { Choose one } \\
\text { picture from pre- } \\
\text { selected pictures } \\
\text { from the teacher. } \\
\text { Then rotate, flip } \\
\text { and slid the } \\
\text { picture then write } \\
\text { the suitable term } \\
\text { in Word. }\end{array}$ & $\begin{array}{l}\text { The lecture-based activity links } \\
\text { everyday life to the new } \\
\text { knowledge. }\end{array}$ & $\begin{array}{l}\text { Satisfac- } \\
\text { tory }\end{array}$ \\
\hline
\end{tabular}

Note: * Terminology used to describe teacher and student activities were adopted from Kozma (2003).

Looking at the activities that are carried out by the teacher and their students while using ICT it was found that the teachers mainly focused on how to present their topic to their students, followed by ways to assess students by using online questions and in some cases by creating a product in teams or using a weblog, Google docs or email to present a product and reflect on it with others.

In general it can be seen that teams were able to choose a topic related to science or mathematic curriculum at the primary school and they tried to find a suitable way to teach the chosen topic with a certain pedagogy and an ICT tool. It is clear from the analysis that all teams used a PowerPoint presentation as a way to present the lesson to their pupils: all lessons started with a presentation of new concepts either by using a digital story or a presentation. After this the pupils were asked to do more tasks, usually as a team, while using ICT tools for homework or to reinforce what was presented by the pre-service teacher. 


\subsubsection{Learning outcomes after working in DTs}

The assessment of TPACK-related learning outcomes of the pre-service teachers are presented in Table 5.8. As can be seen in the table, the means of all scores are above the mean of each scale, indicating that their presentation, explanation, definition, reflection, lesson plan, and their final product were all scored as (at least) sufficient.

Table 5.8 Descriptive statistics of learning outcomes

\begin{tabular}{|c|c|c|c|c|c|}
\hline $\begin{array}{l}\text { Measure } \\
\text { (total points) }\end{array}$ & $\begin{array}{l}\text { Kind of } \\
\text { instrument }\end{array}$ & Knowledge type & $\begin{array}{l}\text { Min- } \\
\text { Max }\end{array}$ & Mean & SD \\
\hline Presentation (6) & Observation & Confidence/schematic & $0-6$ & 4.88 & .892 \\
\hline Explanation (4) & Observation & Schematic & $0-4$ & 3.44 & .519 \\
\hline $\begin{array}{l}\text { TPACK definition } \\
\text { (3) }\end{array}$ & $\begin{array}{l}\text { Open ended } \\
\text { questionnaire }\end{array}$ & Declarative & $0-3$ & 1.90 & .657 \\
\hline $\begin{array}{l}\text { TPACK reflection } \\
\text { (15) }\end{array}$ & $\begin{array}{l}\text { Open ended } \\
\text { questionnaire }\end{array}$ & Strategic & $0-15$ & 10.47 & 2.849 \\
\hline $\begin{array}{l}\text { Lesson plan score } \\
\text { (16) }\end{array}$ & $\begin{array}{l}\text { Performance } \\
\text { assessment }\end{array}$ & Strategic & $1-16$ & 12.74 & 3.206 \\
\hline Product score (60) & $\begin{array}{l}\text { Performance } \\
\text { assessment }\end{array}$ & Strategic & $0-60$ & 50.99 & 5.928 \\
\hline
\end{tabular}

The results of the ICT skills test at the beginning and at the end of intervention are presented in Table 5.9. The participants gained a significant higher score at the end of the intervention with a large effect size $(d=2.04)$.

Table 5.9 Comparison of the pre-service teachers ICT skills

\begin{tabular}{|l|l|l|c|c|c|c|} 
& $\begin{array}{l}\text { Kind of } \\
\text { instrument }\end{array}$ & $\begin{array}{l}\text { Knowledge } \\
\text { type }\end{array}$ & $\begin{array}{c}\text { Pre } \\
\text { Mean (SD) }\end{array}$ & $\begin{array}{c}\text { Post } \\
\text { Mean (SD) }\end{array}$ & $\begin{array}{c}\text { P } \\
\text { (level of } \\
\text { significance) }\end{array}$ & $\begin{array}{c}\text { Effect } \\
\text { size }\end{array}$ \\
\hline $\begin{array}{l}\text { ICT skill } \\
\text { test }\end{array}$ & $\begin{array}{l}\text { Performance } \\
\text { assessment }\end{array}$ & Procedural & 7.72 & 13.96 & 0.0001 & 2.04 \\
\hline
\end{tabular}

Note: Total points of the test $=20$.

To examine the relationship between the outcome measure the Pearson correlation was calculated between the different learning outcomes mentioned in Table 5.8 and the ICT skill test score of Table 5.9. The result of the Pearson correlation indicated that there is a positive correlation between almost all learning outcomes as shown in Table 5.10. 
Table 5.10 Pearson Correlation Matrix among learning outcomes

\begin{tabular}{|c|c|c|c|c|c|c|c|}
\hline & $\begin{array}{l}\text { Expla- } \\
\text { nation }\end{array}$ & $\begin{array}{c}\text { Presen- } \\
\text { tation }\end{array}$ & $\begin{array}{c}\text { TPACK } \\
\text { definition }\end{array}$ & $\begin{array}{c}\text { TPACK } \\
\text { reflection }\end{array}$ & $\begin{array}{l}\text { Product } \\
\text { score }\end{array}$ & $\begin{array}{l}\text { Lesson } \\
\text { plan } \\
\text { score }\end{array}$ & $\begin{array}{c}\text { ICT } \\
\text { skill } \\
\text { test }\end{array}$ \\
\hline Explanation & 1.000 & & & & & & \\
\hline Presentation & $.361^{* *}$ & 1.000 & & & & & \\
\hline $\begin{array}{l}\text { TPACK } \\
\text { definition }\end{array}$ & $.361^{* *}$ & & 1.000 & & & & \\
\hline $\begin{array}{l}\text { TPACK } \\
\text { reflection }\end{array}$ & $.492^{* *}$ & $.434^{* *}$ & $.842^{* *}$ & 1.000 & & & \\
\hline Product score & $.485^{* *}$ & $.345^{\star *}$ & & $.331^{* *}$ & 1.000 & & \\
\hline $\begin{array}{l}\text { Lesson plan } \\
\text { ccore }\end{array}$ & $.494^{* *}$ & $.277^{*}$ & & $.282^{*}$ & $.873^{* *}$ & 1.000 & \\
\hline ICT skill test & $.406^{* *}$ & $.285^{*}$ & $.543^{* *}$ & $.554^{* *}$ & $.254^{*}$ & $.301^{*}$ & 1.000 \\
\hline
\end{tabular}

As can be seen in the table there is a medium to high correlation between the ability to explain TPACK (schematic knowledge) with all other learning outcomes. This is also true for the correlation between the score on the ICT skill test with all other learning outcomes. It can also be seen that the ability to define TPACK (which is declarative knowledge) is highly correlated with reflecting on a TPACK teaching situation and the ICT skill test, but not to the score for the product or the lesson plan. On the other hand, reflecting on a TPACK teaching situation does have a medium correlation with the scores on the product and the lesson plan. And, as can be expected the score on the product and the score on the lesson plan are highly correlated.

\subsubsection{Self-reported measures and the learning outcomes of TPACK}

The results of the TPACK survey are presented in Table 5.11. The results show that the respondents gained significantly on the different knowledge domains related to the TPACK framework with a large effect size. 
Table 5.11 Comparison of the pre-service teachers' perception of their TPACK

\begin{tabular}{|l|c|c|c|c|}
\hline Factor & $\begin{array}{c}\text { Pre } \\
\text { mean }(S D)\end{array}$ & $\begin{array}{c}\text { Post } \\
\text { mean }(S D)\end{array}$ & $\begin{array}{c}\text { P } \\
\text { (level of significance) }\end{array}$ & Effect size \\
\hline TK & $3.15(.548)$ & $3.80(.506)$ & 0.0001 & 1.23 \\
\hline CK & $3.55(.735)$ & $4.13(.404)$ & 0.0001 & 0.98 \\
\hline PK & $3.65(.499)$ & $4.28(.379)$ & 0.0001 & 1.41 \\
\hline PCK & $3.58(.699)$ & $4.22(.457)$ & 0.0001 & 1.09 \\
\hline TCK & $3.20(.664)$ & $4.22(.494)$ & 0.0001 & 1.74 \\
\hline TPK & $3.10(.481)$ & $4.21(.438)$ & 0.0001 & 2.42 \\
\hline TPACK & $2.99(.475)$ & $4.12(.419)$ & 0.0001 & 2.53 \\
\hline
\end{tabular}

Note: $1=$ Strongly Disagree (SD); $2=$ Disagree (D), $3=$ Undecided $(\mathrm{U}), 4=$ Agree $(\mathrm{A})$ \& $5=$ Strongly Agree (SA).

Based on the pre-test of the TPACK survey, the correlation among the different TPACK domains were calculated and are presented in Table 5.12. In general the findings show that the correlation among the different knowledge domains of the TPACK framework are small or medium or do not exist. In other words: the pre-service teachers do not integrate the different knowledge areas in their thinking about ICT integration in education.

Table 5.12 Pearson correlation matrix between TPACK domains (pre-measure)

\begin{tabular}{|c|c|c|c|c|c|c|c|}
\hline & TK & CK & PK & PCK & TCK & TPK & TPACK \\
\hline TK & 1.000 & & & & & & \\
\hline CK & $.293^{*}$ & 1.000 & & & & & \\
\hline PK & $.267^{*}$ & $.481^{\star *}$ & 1.000 & & & & \\
\hline PCK & & $.312^{* *}$ & $.681^{* *}$ & 1.000 & & & \\
\hline TCK & $.371^{* *}$ & & $.384^{* *}$ & $.332^{* *}$ & 1.000 & & \\
\hline TPK & $.414^{\star *}$ & & $.314^{* *}$ & & $.425^{* *}$ & 1.000 & \\
\hline TPACK & $.507^{* *}$ & $.383^{* *}$ & & & $.296^{*}$ & $.273^{*}$ & 1.000 \\
\hline
\end{tabular}

Note: ${ }^{* *}$. Correlation is significant at the 0.01 level (2-tailed), *. Correlation is significant at the 0.05 level (2-tailed).

However, when using the post-test measure and calculating the Pearson correlation of the different knowledge domains of the TPACK framework the correlations increased (see Table 5.13). The results show that in pre-service students' perceptions TK, PK, CK and their intersections are positively correlated. 
Table 5.13 Pearson correlation matrix between TPACK different domains (post-measure)

\begin{tabular}{|c|c|c|c|c|c|c|c|}
\hline & TK & CK & PK & PCK & TCK & TPK & TPACK \\
\hline TK & 1.000 & & & & & & \\
\hline CK & $.437^{* *}$ & 1.000 & & & & & \\
\hline PK & $.477^{* *}$ & $.378^{* *}$ & 1.000 & & & & \\
\hline PCK & $.334^{* *}$ & $.339 * *$ & $.693^{* *}$ & 1.000 & & & \\
\hline TCK & $.442^{* *}$ & $.444^{* *}$ & $.476^{* *}$ & $.455^{\star * *}$ & 1.000 & & \\
\hline ТPK & $.575^{\star * *}$ & $.469^{* *}$ & $.542^{* *}$ & $.344^{* *}$ & $.566^{* *}$ & 1.000 & \\
\hline TPACK & $.662^{* *}$ & $.468^{* *}$ & $.538^{* *}$ & $.438^{* *}$ & $.578^{* *}$ & $.704^{* *}$ & 1.000 \\
\hline
\end{tabular}

Note: **. Correlation is significant at the 0.01 level (2-tailed), *. Correlation is significant at the 0.05 level (2-tailed).

To further examine the relationship between the learning outcomes and the self-reported data we ran another Pearson correlation. The findings (see Table 5.14) show that significant correlations were only found between TK and the ICT skills test, and between TCK and the ability to define TPACK and the ICT skill test, and between TPK and the product score, lesson plan and the ICT skill test, but the correlation between self-reported TPACK and TPACK learning outcomes (if it exists) is very small.

Table 5.14 Pearson correlation coefficient between TPACK domains and learning outcomes

\begin{tabular}{|c|c|c|c|c|c|c|c|}
\hline & $\begin{array}{l}\text { Expla- } \\
\text { nation }\end{array}$ & $\begin{array}{c}\text { Presen- } \\
\text { tation }\end{array}$ & $\begin{array}{c}\text { TPACK } \\
\text { definition }\end{array}$ & $\begin{array}{l}\text { TPACK } \\
\text { reflection }\end{array}$ & Product & $\begin{array}{c}\text { Lesson } \\
\text { plan }\end{array}$ & $\begin{array}{l}\text { ICT } \\
\text { skill } \\
\text { test }\end{array}$ \\
\hline TK & & & & & & & $.261^{*}$ \\
\hline CK & & & & & & & \\
\hline PK & & & & & & & \\
\hline PCK & & & & & & & \\
\hline TCK & & & $.245^{*}$ & & & & $.261^{*}$ \\
\hline TPK & & & & & $.253^{*}$ & $.243^{*}$ & $.239^{*}$ \\
\hline TPACK & & & & & & & \\
\hline
\end{tabular}

Note: *. Correlation is significant at the 0.05 level (2-tailed). 


\subsection{CONCLUSION AND DISCUSSION}

This study aimed to investigate the effectiveness of various measures for assessing pre-service teachers' TPACK The different measures applied (TPACK Explanation, TPACK presentation, TPACK definition, TPACK reflection, TPACK lesson plan and product, ICT skills) in the study examined which TPACK learning outcomes the pre-service teachers demonstrated after working in Design Teams on ICT integration and how they are related and if the learning outcomes of the pre-service teachers are related to their self-reported TPACK.

Based on the results related to the TPACK learning outcomes such as the lesson plan, the product and the TPACK definition and reflection questions, it was found that the pre-service teachers were able to develop an ICT-enhanced product (labelled in this study as technology use at the strategic level) and integrate it in their lesson plan (strategic level) to solve a problem related to science or mathematic teaching. The pre-service teachers were able to define TPACK (declarative level) and were able to describe (strategic level) a situation in which they can use the TPACK framework to teach a topic related to primary school science or mathematic. They were also able to present their product to their peers and instructors, and defend their choice of ICT tool, design related issues (i.e. consistency, contrast, balance, colour scheme...etc.), and pedagogically building their argument of different domain of TPACK (technology use at the schematic level and an indicator for confidence). The preservice teachers' ICT skills (procedural level) increased significantly after working in the DTs. This indicates that the pre-service teachers were able to demonstrate or express their TPACK understanding at different knowledge levels: declarative, procedural, schematic and strategic level.

Results from the self-reported TPACK (confidence) measure indicate that preservice teachers significantly increased their TPACK during the intervention, with a large effect size in the different domains of TPACK, ranging from 0.98 to 2.53. Interestingly, the pre-intervention correlations among the different TPACK domains of the TPACK survey were weak; which may indicate that the preservice teachers had a superficial or incomplete TPACK before the intervention started. The post-intervention TPACK self-report measures were significantly correlated and this may indicate that the pre-service teachers' TPACK was strengthened and did further develop, and that the pre-service teachers had a 
better understanding of TPACK and were more able to think about the integrative focus of TPACK. This was also described by Koehler, Mishra, and Yahya (2007) that "At the heart of TPACK is the dynamic, transactional relationship between content, pedagogy, and technology. Good teaching with technology requires understanding the mutually reinforcing relationships between all three elements taken together to develop appropriate, context-specific, strategies and representations (p. 741). Koehler, Mishra, and Yahya also argued that the conceptualization of TPACK goes beyond seeing content, pedagogy, and technology as constructs in and of themselves. In general this may indicate that the ICT-related intervention by working in DTs supports in the development of TPACK.

However, correlations between the TPACK learning outcomes and the TPACK self-reported outcomes appeared to be small and not significant. One explanation could be that the self-reported measure is dealing with pre-service teachers' perception and confidence about TPACK, while the instruments that measured learning outcomes were assessing the knowledge the pre-service teachers had developed. Pre-service teachers' perception and confidence as measured by the TPACK survey is related to Bandura's (1977) notion of selfefficacy, one's perceived ability to perform an action that will lead successfully toward a specific goal. The instruments that measured learning outcomes were assessing two types of knowledge. First of all, what pre-service teachers know was analysed by using the data from the definition rubric that assesses TPACK at the declarative knowledge level, and the explanation rubric that assesses TPACK at the schematic knowledge level. Secondly, they assessed what the pre-service teachers were able to do, as assessed by the reflection rubric, the lesson plan rubric, and the product rubric, all assessing TPACK at the strategic level. From the literature we know that what teachers think they know or what they think they can do (their self-efficacy) is not necessarily aligned with what they really know or what they do in practice (Agyei \& Voogt, 2011; Harris, Grandgenett, \& Hofer, 2010; Lawless \& Pellegrino, 2007; Schrader \& Lawless, 2004). Keys (2005) conducted a study to compare teachers' statements and claims about their practice with their actions and he found that the expressed statements about what they know or do were often a desire to be adopted but they were unwilling to make certain sacrifices in order to do so. However, although there might be a difference between teachers' self efficacy as measured by the TPACK survey and the learning outcomes measures, we would have expected positive correlations between the two types of measures. 
Several studies about the relation between self-efficacy and actual teacher behaviour have shown that self-efficacy is a good predictor for actual teaching behaviour (e.g. Tschannen-Moran \& Hoy, 2001)

For this reason we consider another explanation for the absence of significant correlations between the self-reported data and the learning outcomes. A closer inspection of the items that constitute the TPACK survey shows that in the TPACK Survey TPACK is addressed in a general and abstract way (e.g. I know how to solve my own technical problems, or I can choose technologies that enhance the content for a lesson), while the instruments that are assessing the TPACK learning outcomes are assessing pre-service teachers' TPACK in a specific and concrete way (e.g. using video to replace the real experiment to observe the development of the embryo inside the egg, or identifying the added value from using blogs to discuss environmental pollution). Based on our results and experiences with the TPACK Survey we have reservations about the general and abstract way pre-service teachers are asked to report on their TPACK. To be able to really measure someone's self-efficacy of his or her TPACK the survey should be more tailored to the concrete educational practice of the person who is asked to fill in the survey. This implies that it should be for instance much more specific on the kind of learning difficulties that students encounter when a specific topic is being taught. Or, as Archambault, and Barnett (2010) argue "items that were developed to measure this construct within the current instrument were written with the intent of being generalizable so that teachers could apply them to their own subject-matter. The challenge becomes creating and validating an instrument that is applicable in a multitude of contexts, including different content areas" (p. 1659). Reflecting on the experiences and the results we conjecture that the current TPACK Survey is not measuring pre-service teachers' self-efficacy towards TPACK, but is measuring perceived general knowledge about how to use technology in educational practice. From our perspective such a measure is contrary to the original intention of TPACK which is, similar to PCK (Shulman, 1987), related to pre-service teachers' perceptions of the affordances of technology to support students' learning of a specific topic in a specific context with its own difficulties and misconceptions. This could explain the weak correlation between the self-reported data and learning outcomes. Such a conclusion would not only question the validity of the TPACK survey, but also call for a better understanding of what TPACK as a construct encompasses. 
To be able to measure TPACK development in a valid and reliable way we first need to agree upon the definition of TPACK as a construct, before using various instruments of which we are not sure whether they measure TPACK as intended. Therefore, we strongly advocate the use of learning outcomes by which students can demonstrate their TPACK, because the outcomes sufficiently demonstrate what students can actually do with technology/ICT to enhance teaching and learning. Our study showed that these outcomes provide specific and concrete representations of pre-service teachers' TPACK knowledge as well. We do not deny the importance of self-report instruments, because they might provide useful information about pre-service teachers 'selfefficacy. However, as long as agreement about TPACK as a construct is lacking it is difficult to validly and reliably develop self-report instruments that measure pre-service teachers TPACK in a specific context. 


\title{
CHAPTER 6
}

\section{Epilogue}

\begin{abstract}
This chapter summarizes the findings of our study, reflects on the findings, on the research approach and on the application of Design Teams, and gives recommendations for preparing pre-service teachers with the competencies for ICT integration and for future research. The chapter starts with a general overview of the study by stating the aims and research questions. Then the findings of the different sub studies are reviewed with a focus on the subresearch questions, the findings, and how the findings from each sub-study were used to guide the development of the next sub-study. After this the different study findings and the research methodology are reflected upon. The chapter ends with recommendations for practical implications and further research.
\end{abstract}

\subsection{RECAPITULATION: AIMS AND RESEARCH QUESTIONS}

Recent advances in Information and Communication Technology (ICT) do not only change our daily lives but education as well. As a consequence, there is a growing need for ICT integration in education. Teachers are considered to play a critical role in teaching and learning, and they need to develop ICT competencies to effectively integrate ICT in their daily classroom practice. This study focused on the preparation of pre-service teachers in using ICT in teaching educational content in rich and meaningful ways. The main aim of this study was to firstly identify conditions for effective teacher preparation, secondly to design interventions by which relevant teaching competencies are developed, and thirdly more specifically, to measure the impact and effectiveness of these interventions on pre-service teacher preparation to use ICT for teaching and learning.

Meaningful use of ICT in education requires teachers to develop the knowledge that enables them to integrate ICT with a suitable pedagogical approach for 
teaching specific subject matter in a certain context. This integrated knowledge is referred to as Technological Pedagogical Content Knowledge (TPACK). One strategy to reach ICT integration by pre-service teachers in education, developed and investigated in this study, was to develop TPACK through learning technology by design.

The context of this study was the teacher preparation program at the Public Authority of Applied Education \& Training (PAAET) in Kuwait. The teacher preparation program, and in particular the science teacher preparation program at PAAET on which this study focuses, includes some courses on ICT skills, but only as stand-alone ICT skills courses, on the assumption that acquiring ICT skills will lead automatically to effective integration of ICT by pre-service teachers in their future classroom practices. In this study, pre-service science teachers studying at the science teacher preparation program at PAAET collaborated in Design Teams (DTs) to design curriculum materials and subsequently develop their competencies for ICT integration, including their TPACK.

The main research question in this study was:

"What are the effects of working in Design Teams on the knowledge, skills and attitudes pre-service teachers need to be able to integrate ICT in their future teaching practice?"

From the main research question, four sub questions were derived. The subquestions are:

5. What are the perceptions, attitudes, and needs of pre-service teachers in relation to ICT integration and what are the conditions for successful usage of ICT at PAAET?

6. What changes could be observed in Technological Pedagogical Content Knowledge (TPACK), ICT skills, and attitudes toward ICT of pre-service science teachers who participated in Design Teams?

7. What differential effects do Human Support and Blended Support have on pre-service teachers' development of TPACK, and their attitude and skills related to ICT?

8. What TPACK learning outcomes do pre-service teachers demonstrate after working in Design Teams on ICT integration and how are these TPACK learning outcomes related to their self-reported TPACK? 


\subsection{RESEARCH APPROACH}

The research approach adopted in our study is design-based research, which is a systematic method that is characterized by observing and addressing complex problems in their natural setting with the aim to improve educational practice through iterative cycles of analysis, design, development, and implementation. Reeves (2006) indicated that design-based research has two objectives: to develop creative approaches for solving performance or teaching/learning problems, and at the same time construct a body of design principles that informs theory and could be used to guide efforts in future developments. Design-based research is challenging because the researcher not only needs to understand what is happening in a particular context, the researcher should also be able to show the relevance of the findings from the context of the intervention to other contexts.

The research activities in this study were based on Reeves' (2000) model of design-based research which consists of four main phases: analysis of the problems that the researcher and the practitioners encounter, develop plausible solutions to these complex problems, refinement of the solution based on testing and evaluation, and documentation of and reflection on the outcomes of the design. These phases are reported in the different studies.

\subsection{STUDIES REPORTED}

\subsubsection{1st study: Feasibility, perceptions, and attitudes}

The purpose of the first study was to answer the following question: 'What are the perceptions, attitudes, and needs of pre-service teachers in relation to ICT integration and what are the conditions for successful usage of ICT at PAAET?', to inform and support the development of ICT integration in the science teacher preparation program. From previous studies (e.g. Albirini, 2006; Baylor \& Ritchie, 2002; Knezek \& Christensen, 2008) numerous factors are known to affect the use of computers in the classroom. Teachers' attitudes toward computers are directly related to their use of computers in the classroom, are critical for the adoption of ICT in the classroom, as well as for personal use, and determine the success or failure of the introduction of ICT in the classroom. Assessing teachers' attitudes toward ICT use 
may provide useful insights in the process of ICT integration, ICT acceptance, and ICT usage in teaching and learning and could be a good predictor for teachers' future use of ICT. In addition, teachers' ICT skills are a significant predictor of their attitudes toward computers and studies showed that although many teachers believe computers are important tools for education, they avoid using computers in their instruction because they lack confidence about using computers due to lack of knowledge and skills. Therefore the perceptions of preservice science teachers at PAAET regarding the current curriculum, especially in relation to ICT, their attitudes toward ICT, skills of ICT use, and their ICT training needs were assessed. This study revealed that pre-service science teachers at PAAET reported that they have a positive attitude toward ICT, that they have basic ICT skills and that they are aware of ICT and its potential role in education, but they are not sure about their ability to integrate ICT into their teaching. They do not consider themselves to be ICT-integrating teachers, which was attributed to the following reasons: 1) the ICT-focused courses do not provide students with the ability to integrate ICT in practice, 2) there is limited ICT integration throughout the program, so the pre-service teachers do not experience authentic use of ICT in teaching and learning, and 3) traditional teaching methods throughout their preparation program at PAAET. Based on these results and on a review of the literature, suggestions to support pre-service teachers to better understand and experience the role ICT in education, were proposed: 1) to help pre-service teachers understand how student-centred practices, supported by ICT, impact student learning; 2) to provide pre-service teachers with concrete examples of what teaching with ICT looks like in practice and to facilitate change in teachers' knowledge and attitudes about ICT; 3) to provide pre-service teachers with opportunities to explore and experiment with the pedagogical uses of ICT tools to help pre-service teachers to become more confident about integration; and 4) to work in an authentic, collaborative learning environment as a suitable strategy to prepare pre-service teachers to integrate ICT in their future practices. The results of this study provided an adequate input for the second study in which promising directions for the integration of ICT in the science teacher preparation program at PAAET are discussed and designed.

\subsubsection{2nd study: TPACK and Teacher Design Teams}

Teachers need to experience and practice ICT-integration throughout their undergraduate programs to become ICT-integrating teachers. Studies by, amongst others, Koehler and Mishra (2005) emphasized that teacher education 
programs needs to develop students' Technological Pedagogical Content Knowledge (TPACK) to enable pre-service teachers to use ICT successfully in their daily practices after graduation. The knowledge domains related to TPACK include Content Knowledge (CK), knowledge about the subject matter (in this study Science), Pedagogical Knowledge (PK), knowledge about educational processes, teaching strategies and teaching methods, and Technological Knowledge (TK), knowledge about ICT affordances and constraints, and ICT skills. The intersection and interaction between CK, PK, and TK produces Technological Pedagogical Content Knowledge (TPACK). One strategy to develop TPACK, advocated by Koehler and Mishra (2006), is through working in Design Teams (DTs). The second study aimed to identify pre-service science teachers' development of TPACK through DTs and answered the second research question 'What changes could be observed in Technological Pedagogical Content Knowledge (TPACK), ICT skills, and attitudes toward ICT of pre-service science teachers who participated in Design Teams?'. It was expected that by working in DT, the pre-service science teacher will experienced student-centred practices through authentic, active and collaborative learning environment. Designing an ICT enhanced lesson will give the pre-service science teachers the opportunities to explore and experiment with the ICT tools, to experience the pedagogical uses of ICT tools to understand what teaching with ICT will look like in practice and how integration of ICT in science curriculum will impact student learning, and to provide pre-service science teachers with concrete examples about effective ICT integration in science education. The whole experience will support the development of competencies needed by pre-service science teachers for ICT integration.

In this second study, DTs were formed to design an ICT enhanced solution for an authentic educational problem related to the primary science curriculum. The DTs were coached by ICT, content, and pedagogy experts. During the design process, the pre-service science teachers developed their ICT skills, and started thinking about ICT as a tool for achieving instructional objectives, rather than considering ICT as an end in itself. The pre-service teacher became an active learner, collaborated with different team members, learned by doing and experimented with different kinds of ICT-tools to solve the pedagogical problems they encountered. This study provided pre-service science teachers at PAAET with the competencies required for an ICT-integrating teacher. The results of the second study showed that the ICT skills of the pre-service teachers 
increased significantly after they worked in DTs to develop or design a solution for a problem related to the specific science content by using a suitable pedagogy and appropriate ICT tools. The pre-service teachers developed a positive attitude toward both ICT and team work, and their TPACK had increased after working in DTs. This meant that the pre-service teachers had positive experiences with using ICT and gained ICT related skills. Additionally, the pre-service teachers reported an increase in the usefulness and ease of ICT use at the end of the intervention, which indicated that the pre-service teachers allegedly increased their confidence and competence in using ICT. The findings provided evidence that working in a DT by the pre-service science teachers at PAAET fostered the development of TPACK, which is the knowledge needed by pre-service teachers for ICT integration in their practices.

\subsubsection{3rd study: Blended support for learning}

From the second study the experts who coached the pre-service science teachers indicated that the face-to-face support they provided to the DTs during the course was essential in routing students thinking toward TPACK. However, both the experts and the pre-service science teachers acknowledged that supporting the DTs face-to-face is time consuming and asked for more flexibility related to time and delivery, as an important feature of an environment to support the development of TPACK in DTs. Beside the flexibility the pre-service teachers stressed a need for a support system or environment in the Arabic language. Since students at the teacher preparation program at PAAET are used to learn in a teacher-centred approach, an online environment that completely replaces the support of the expert instructors therefore might not be an effective strategy. For this reason a blended approach to support the DTs was explored in this study. The third study was to explore whether providing Blended Support (on-line support integrated in face-to-face support by expert instructors) for learning could be an effective and efficient alternative to support the development of TPACK in the pre-service science teachers while working in DTs. The main research question was: 'What differential effects do Human Support and Blended Support have on pre-service teachers' development of TPACK, and their attitude and skills related to ICT?'. It could also confirm the findings from the previous study that working in DTs to design an ICT- enhanced lesson is a promising way for the development of TPACK in pre-service science teachers at PAAET. Two kinds of support were 
distinguished: human support and blended support. The human support was provided by the different experts on pedagogy, science/math content and ICT respectively. The blended support was an online support portal in Moodle, containing tutorials on how to use different kinds of software, examples of lesson plans that integrate ICT, a matrix of different ICT applications with suitable teaching methods, and examples or URL links on using ICT in science/math education. The portal also supported online expert support through a chat tool and offered a workplace for DTs to share documents, a discussion forum to reflect on what's going on in class, and to answer a weekly question. Beside using the portal the pre-service students in the Blended support condition had the opportunity to consult the experts face to face. The results from the third study was that both the Human Support and Blended Support condition showed significant positive effects on teacher's attitude, knowledge and skills that are needed for ICT integration. This lead to the conclusion that the human support and the blended support conditions are successful alternatives for supporting the pre-service teachers. Blended support however showed higher gains in attitudes toward ICT, Technological Pedagogical Knowledge (TPK), and Technological Knowledge (TK). No differences between the two conditions were found in the anxiety and frustration constructs toward computers, ICT skills (test and survey) and except for TK and TPK - the other aspects of TPACK. Based on the findings of this study it was concluded that applying the DT approach combined with the Blended Support approach is beneficial for the pre-service teachers and the instructors that guide them. The pre-service teachers showed higher gains in attitudes toward ICT, TPK TK, they gained more experience with ICT use, and they experience a student-centred approach. For the instructors the Blended Support for Learning meant an effective and, above all, a more efficient way of supporting the pre-service teachers.

\subsubsection{4th study: Measuring TPACK development}

The fourth study pertained to assessing pre-service teachers' TPACK and tried to examine which TPACK learning outcomes the pre-service teachers demonstrated after working in DTs on ICT integration and if the learning outcomes of the pre-service teachers were related to their self-reported TPACK. The research question for this study was: 'What TPACK learning outcomes do preservice teachers demonstrate after working in Design Teams on ICT integration and 
how are these TPACK learning outcomes related to their self-reported TPACK?'. What students learned about TPACK was determined through a diversity of measures. Therefore, to uncover and understand more of the complexity inherent to the situatedness of the TPACK construct, this study addressed a mixed-method assessment of teachers' ICT integration knowledge, specifically focusing on teachers' self-reports, their perceptions, as opposed their learning outcomes as demonstrated in a lesson plan, the ICT product, the TPACK definition and reflection questions, and the ICT skills test. Based on the results related to the TPACK learning outcomes, the fourth study showed evidence that the pre-service teachers were able to develop an ICT-enhanced product and were able to integrate this product in a lesson plan, that aims to solve a problem related to science or mathematic teaching in primary school. The pre-service teachers were able to define TPACK and to describe a situation to express that they can use the TPACK framework to teach a topic related to primary school science or mathematics. They were also able to present their product to peers and instructors and to defend their choice of ICT tool, design related issues (i.e. consistency, contrast, balance, colour scheme, .etc.), and pedagogy. They were able to build their argument using the different domains of TPACK. The study also showed that pre-service teachers' ICT skills increased significantly after working in the DTs. The findings indicated that pre-service teachers were able to demonstrate their TPACK understanding at different knowledge levels: declarative, procedural, schematic and strategic. Based on the pre-test of the TPACK survey, the correlation among the different TPACK domains were small or medium or did not exist. In other words: the pre-service teachers did not integrate the different knowledge areas in their thinking about ICT integration in education. Which indicates that the pre-service teachers' selfassessment of TPACK was superficial or incomplete before the intervention started. However, the correlation among the post-test measure of the TPACK survey showed significant positive correlations between TK, PK, CK and their intersections. This indicated that the pre-service teachers' self-assessment of their understanding of TPACK had developed However, a closer inspection of the data revealed no correlations between the self-reported findings and TPACK learning outcomes. This indicates that the students' own perception of their TPACK development was not necessarily aligned with the way they were able to demonstrate the integration of ICT, pedagogy and content in practice. This unexpected finding questioned the validity of the way TPACK was measured in the TPACK survey. The TPACK survey asks the pre-service 
teachers to report on their TPACK in a general and abstract way. To be able to really measure someone's TPACK through self-assessment, the survey should be more tailored to the concrete educational practice of the person who is asked to fill in the survey. This implies that the instrument should be more specific about the way specific ICT tools could help to prevent the development of misconceptions in students. The reason behind the problem with the TPACK survey may be due to the fact that the definition of the TPACK construct is still quite vague. The main goal of this study was to prepare pre-service teachers for ICT integration in teaching and learning. For this reason, the learning outcomes the pre-service teachers demonstrated better showed their ability to integrate ICT in teaching and learning, and therefore are a better indicator of their TPACK then the TPACK survey.

\subsection{REFLECTIONS OF THE RESEARCH APPROACH}

Adopting a design-based research approach in the context of studying the knowledge, skills and attitudes that pre-service teachers at PAAET need to be able to integrate ICT in their future teaching practice helped in closing the research-practice gap. The design-based research approach acknowledges the fact that there could be a considerable overlap in the role of a researcher when she is also a teacher, developer, and a facilitator in the research process. And this has been important in the specific context in which this study has been carried out. By acting through different roles the researcher gained an in-depth understanding of the context and the research problem and that aids in designing and solving the research problem. This deepened understanding provides additional insights that helped to adequately analyse the research problem and to design an intervention to solve it.

By being a faculty member at PAAET the design-based research approach gave the researcher an inside view of the status of the program and the students in ways that cannot be accomplished as easy by an external researcher. By being a teacher and a developer of the intervention helped to influence the ICT integration process and made it possible that the data collection activities were seamlessly integrated into the on-going courses. This process of overlapping roles, activities and responsibilities made the developed intervention ecologically valid and relevant and usable to those who need it. 
This research approach, close to the authentic setting, however limits the generalizability of the findings. In other words, can the results that were realized at PAAET also be realized in other settings? Design-based research is on the one hand informed by theory and produces new insight in theory, but on the other hand the knowledge produced by design-based research relates to a certain class of problems, within certain domains, as encountered in certain settings (cf. van Aken, 2004). It is however possible to make cautious inferences, and propose theories to explain what we see, even when we are sensitive to contextual factors. This can be done by explicating the local conditions as an integrated element of the results of design research ( Hoadley 2004; McKenney, Nieveen \& van den Akker, 2006; Reinking \& Bradley 2008; Tabak, 2004).

Applying the design-based research approach in this study led to a specific intervention (working in Design Teams on developing knowledge, skills and attitudes pre-service teachers need to be able to integrate ICT in their future teaching practice) with positive results in the specific context of PAAET. Moreover, the approach and the subsequent outcomes also give future directions for other settings, especially related to the development of TPACK by working in Design Teams and measuring TPACK by self-reported and learning outcomes.

\subsection{REFLECTIONS ON OUTCOMES}

\subsubsection{The importance of the needs and context analysis}

This study started with a needs and context analysis phase (described in Chapter 2). This phase was conducted to better understand the status of ICT and teaching methods within the program of PAAET, and to better understand the suitable condition(s) for ICT integration within the program for equipping the pre-service teachers with competencies needed for ICT integration in their future practice. To accomplish this phase, it was important to assess the perceptions of the pre-service science teachers at PAAET toward their current curriculum especially in relation to ICT, their attitudes toward ICT, skills of ICT, and their ICT training needs.

The findings from this phase indicated that the inability of the pre-service teachers to integrate ICT in their teaching practices was attributed to the following factors: a) the dependence on teacher-centred approach to teaching 
and learning, b) the lack of integration of ICT into the existing courses of the program and c) the minor role of ICT-skill-related courses for students within the program. These findings helped the researcher to build a tailored intervention for this study, which is context specific for the pre-service science teacher at PAAET. Taking into account the criteria of the context of PAAET and the needs addressed by the pre-service teachers from the start of this study by conducting a context and needs analysis has helped in the success of the implementation of the intervention.

\subsubsection{Effectiveness of Design Teams}

This study used Design Teams as pedagogical approach to prepare pre-service science teachers for ICT integration in their practice. From the findings of this study (Chapters 3 and 4), Design Teams proved to be a successful strategy to develop competencies needed by pre-service teachers to be able to integrate ICT in education. The results of this study (as discussed in Chapter 4) showed how pre-service teachers could be supported while working in DTs: with Human Support or with Blended Support for learning. The Blended Support environment also included communication possibilities among team members, between different teams, and with the course instructor. The Blended Support with the combination of the support and guidance provided by the instructors and the flexibility of an online environment was appreciated by the pre-service teachers and the expert instructors. An advantage of Blended Support over Human Support was that the pre-service teachers experienced the use of ICT tools in an ICT environment for their own learning. In addition the Blended Support mode more than the Human Support mode provided the pre-service teachers with experiences in learning through a student-centred approach. These experiences suggest that at PAAET Design Teams in a Blended Support mode could be a useful format for supporting pre-service teachers in developing their abilities in the integration of ICT.

\subsubsection{Assessing TPACK development}

The need for a variety of measures

With the development of the TPACK framework, it became increasingly important to develop ways to assess TPACK and the different domains related to TPACK. The assessment of TPACK requires new ways of thinking about 
how to assess the learning process in progress, as the pre-service teachers move from novice to expert in ICT integration (Angeli \& Valanides, 2008). This study (Chapter 5) showed that in order to be able to assess TPACK a common understanding and definition of the TPACK framework is needed. Archambault, and Crippen (2009) found that TPACK is difficult to measure because the seven domains of the framework seem confounded and difficult to separate. They argue that measuring TPACK faces the same challenge as measuring PCK. An important reason addressed by Kagan (1990, cited in Baxter \& Lederman, 1999) is that the challenge in assessing PCK, which is also applicable to TPACK; is, that it cannot be directly observed. To overcome the challenges in assessing TPACK/PCK the use of various data sources, as has been done in this study, is to be preferred. The learning outcomes (Chapter 5) were determined by a variety of measures to be able to show pre-service teachers TPACK competencies at the declarative, procedural, schematic and strategic level. The self report data (Chapters 2, 4 and 5) not only reported preservice teachers' self-assessed TPACK, but also their attitudes towards ICT and their ICT skills.

\section{Espoused TPACK and in-use TPACK}

So and Kim (2009) identified two types of TPACK: espoused-TPACK and inused-TPACK: Espoused-TPACK, which implies that pre-service teachers can talk about pedagogically sound ICT integration in a certain content, and in useTPACK which is when teachers are able to translate their attitudes, knowledge and skills to design and implement a pedagogically sound ICT-enhanced lesson for their content within a specific context. The findings from this study showed that the two types of TPACK addressed by So and Kim (2009), were also found in this study. This was very clear in the fourth study (Chapter 5), when the findings from the learning outcomes such as lesson plan and ICT product which is the in-use TPACK did not correlate with the findings from the selfreported TPACK data, which is espoused-TPACK. Teacher educators should be aware of the difference between espoused and in use TPACK and organize learning experiences for pre-service teachers to experience and demonstrate inuse TPACK. The development of an ICT-enhanced lesson plan, and an ICT product, as provided to the pre-service teachers in this study, is a good example of such a learning experience. Conducting an ICT-enhanced lesson during student internship would be another good opportunity to show in use TPACK, but this could not be realised in the frame of this study. 
Development of TPACK: The quest of self-reports

From the final study (Chapter 5) reported in this dissertation, it appeared that correlations between the TPACK learning outcomes and the TPACK selfreported outcomes were small. The study discussed the question whether these two types of measurement were assessing the same thing. The self-reported measure is dealing with pre-service teachers' perception of and confidence in TPACK. This means that it assesses what the pre-service teachers think they know or what they can do (their self-efficacy), but not necessarily their real practice. The absence of significant correlations between the self-reported data and the learning outcomes however was seen as a problem, because a positive correlation between the self-reported data and the learning outcomes was expected when the TPACK survey indeed was measuring pre-service teachers' self-efficacy regarding TPACK. A closer inspection of the items in the TPACK survey (Schmidt et al., 2009) showed that TPACK in the TPACK survey is addressed in a general and abstract way (e.g. I know how to solve my own technical problems, or I can choose technologies that enhance the content for a lesson), while the instruments that are assessing the TPACK learning outcomes are assessing preservice teachers' TPACK in a specific and concrete way (e.g. using video to replace the real experiment to observe the development of the embryo inside the egg, or identifying the added value from using blogs to discuss environmental pollution). To be able to really measure pre-service teachers' self-efficacy of his or her TPACK the survey should be more tailored to the concrete educational practice of the person who is asked to fill in the survey. This implies for instance that it should be much more specific on the kinds of learning difficulties or misconceptions that students encounter when a specific topic is being taught. Reflecting on the experiences and the results we conjecture that the current TPACK Survey is not measuring pre-service teachers' self-efficacy toward TPACK, but is measuring perceived general knowledge about how to use technology in educational practice instead of measuring the teachers' self-efficacy of the affordances of technology to support student learning of a specific topic in a specific context. This could explain the weak correlation between the self-reported data and learning outcomes. To be able to measure TPACK development in a valid and reliable way we first need to agree upon the definition of TPACK as a construct, before using various instruments of which we are not sure whether they measure TPACK as intended. Therefore, the use of learning outcomes by which students can demonstrate their TPACK is strongly recommended, because the outcomes sufficiently demonstrate what students can actually do with ICT to enhance 
teaching and learning. This study showed that these learning outcomes provide specific and concrete representations of pre-service teachers' TPACK knowledge. Self-report instruments are important, because they provide useful information about pre-service teachers' self-efficacy. However, as long as agreement about TPACK as a construct is lacking it is difficult to validly and reliably develop self-report instruments that measure pre-service teachers TPACK in a specific context.

\subsection{RECOMMENDATIONS}

\subsubsection{Design Teams as approach for pre-service science teacher preparation at PAAET}

ICT integration through working in DTs proved to be a successful strategy for: 1) developing the competencies of pre-service teachers at PAAET for ICT integration. By using this approach, the pre-service science teachers learned about ICT tool affordances and constraints for solving teaching and learning problems, ICT related skills, and design processes. This approach of ICT integration moved pre-service teachers from being a passive learner and consumer of ICT to being a more active learner and producer/designer of ICT by learning how to use existing hardware and software in creative and situationspecific ways to accomplish their teaching goals. Next to this, they are able to integrate available ICT in their daily lesson plans and classroom practice. This not only led to more and effective integration of ICT in teaching and learning, but pre-service teachers also experienced a student-centred approach, which they can apply in their future teaching activities. 2) Working in DTs for educational reform proved to generate more ownership and commitment toward the education reform (Nieveen, Handelzalts, \& Van den Akker, 2005). This means working in DTs on ICT integration during their pre-service teacher education program at PAAET may strengthen the ownership of the pre-service teachers toward the ICT integration process. Kereluik, Mishra, and Koehler (2011) indicated that it is important to realize that ICT-based interventions will not reach fruition unless the teachers take ownership. It is therefore recommended that the teacher preparation program at PAAET adopts the DT approach in its curriculum in order to realize not only ICT integration in the future practice of the pre-service teachers, but also in the teacher preparation program itself. 


\subsubsection{ICT integration in the pre-service science teachers preparation curriculum at PAAET}

This study demonstrated that Design Teams as pedagogical approach applied in the 'Educational Seminar' course appeared to be successful. However, the application of DTs in the 'Educational Seminar' course should be considered as a first step. To prepare pre-service science teachers more thoroughly for the use of ICT in their future classroom practice requires that ICT integration needs to be addressed throughout the teacher preparation curriculum. This implies that PAAET has to move away from offering ICT courses in isolation and move toward infusing ICT within content and methodology courses, because in this way the pre-service teachers could be continuously exposed to creative teaching practice with ICT throughout their teacher training program.

\subsubsection{Guidance for beginning teachers' on ICT integration after graduation}

Extra time is needed to get used to, and practice ICT competencies in real classroom settings. Based on experiences from research on PCK (e.g. Van Dijk \& Kattmann, 2007; Van Driel, De Jong \& Verloop, 2002), it can be concluded that the development of TPACK needs to be fostered through real teaching experiences. Because building a strong TPACK knowledge base is a long term trajectory that goes beyond pre-service teacher education in formal settings (Fishman \& Davis, 2006), it is recommended that graduates of the teacher preparation program should have the opportunity to engage in lifelong learning opportunities through an additional (in-service) program. This could be done by providing an online learning support system that could help the pre/in-service teachers in the development of ICT integration in education. This environment can act as learning support, but also as a communication tool for the exchange of ideas between peers and experts. And at the same time the teachers will learn about ICT integration by doing.

\subsubsection{Self- and peer evaluation}

Self- and peer evaluation of the ICT product turned out to be helpful tools in fostering the development TPACK (Chapter 4). However more research is needed to better understand how the added value of both self- and peerevaluation can enhance pre-service teachers' learning about ICT integration in Design Teams. 


\subsubsection{TPACK development through Design Teams for practicing teachers}

This study focused on the development of the attitudes knowledge and skills needed by pre-service teachers' to be able to integrate ICT in their future teaching practice. As argued in section 6.3. the development of competencies needed to integrate ICT in teaching and learning practices is a long term trajectory. To better understand and support the professional learning of practicing teachers about the use of ICT for teaching and learning in Design Teams, research is needed to inform the organization, composition and activities of Design Teams for fostering the development of TPACK in practicing teachers. 


\section{REFERENCES}

Adamy, P., \& Boulmetis, J. (2006). The impact of modeling technology integration on preservice teachers' technology confidence. Journal of Computing in Higher Education, $17(2), 100-120$.

Agyei, D., \& Voogt, J. (2011). Determining teachers' TPACK through observations and selfreport data. In Proceedings of Society for Information Technology \& Teacher Education International Conference 2011 (pp. 2314-2319). Chesapeake, VA: AACE.

Ajzen, I., \& Fishbein, M. (1980). Understanding attitudes and predicting social behavior. Englewood-Cliffs, NJ: Prentice-Hall.

Alayyar, G. (2007). Needs assessment report. Internal report. Enschede: University of Twente.

Alayyar, G., Fisser, P., \& Voogt, J. (in press). Technology integration through design teams in science teacher preparation. International Journal of Learning Technology (IJLT).

Alayyar, G., Fisser, P., \& Voogt, J. (submitted a). Attitude and competencies of pre-service teachers in Kuwait toward Information and Communication Technology: Implications for ICT integration in teacher education. Educational Technology Research and Development.

Alayyar, G., Fisser, P., \& Voogt, J. (submitted b). Developing Technological Pedagogical Content Knowledge in pre-service science teachers: The potential of blended learning. Computers \& Education.

Alayyar, G., Fisser, P., \& Voogt, J. (submitted c). Pre-service teachers' competencies for ICT Integration: What do learning outcomes and self-report data tell? Journal of Educational Computing Research.

Albion, P., Jamieson-Proctor, R., \& Finger, G. (2010). Auditing the TPACK confidence of Australian pre-service teachers: The TPACK Confidence Survey (TCS). In C. Maddux, D. Gibson, \& B. Dodge (Eds.), Research highlights in technology and teacher education 2010 (pp. 303-312). Chesapeake, VA, United States: Society for Information Technology \& Teacher Education (SITE)/Association for the Advancement of Computing in Education (AACE).

Albirini, A. (2006). Teachers' attitudes toward information and communication technologies: The case of Syrian EFL teachers. Computers \& Education, 47(4), 373-398.

Alebaikan, R., \& Troudi, S. (2010). Online discussion in blended courses at Saudi Universities. Procedia - Social and Behavioral Sciences, 2(2), 507-514. 
Alhammar, A. (2006). Investigating electronic portfolios in pre-service teacher education in the Gulf Region (Unpublished doctoral dissertation). University of Twente, Enschede, The Netherlands.

Almodaires, A. (2009). Technology-supported reflection: Towards bridging the gap between theory and practice in teacher education (Unpublished doctoral dissertation). University of Twente, Enschede, The Netherlands. Retrieved from http:/ / dx.doi.org/10.3990/1.9789036528283

Angeli, C., \& Valanides, N. (2005). Preservice elementary teachers as information and communication technology designers: An instructional systems design model based on an expanded view of pedagogical content knowledge. Journal of Computer Assisted Learning, 21(4), 292-302.

Angeli, C., \& Valanides, N. (2008). TPCK in pre-service teacher education: Preparing primary education students to teach with technology. Paper presented at the Annual meeting of the American Educational Research Association, New York.

Angeli, C., \& Valanides, N. (2009). Epistemological and methodological issues for the conceptualization, development, and assessment of ICT-TPCK: Advances in technological pedagogical content knowledge (TPCK). Computers \& Education, 52(1), 154-168. doi: 10.1016/j.compedu.2008.07.006

Archambault, L. M., \& Barnett, J. H. (2010). Revisiting technological pedagogical content knowledge: Exploring the TPACK framework. Computers $\mathcal{E}$ Education, 55(4), 1656-1662. doi: 10.1016/j.compedu.2010.07.009

Archambault, L., \& Crippen, K. (2009). Examining TPACK among K-12 online distance educators in the United States. Contemporary Issues in Technology and Teacher Education, 9(1). Retrieved September 20, 2010, from http://www.citejournal.org/vol9/iss1/general/article2.cfm

Baker, E. L., \& O’Neil, H. R., Jr. (1987). Assessing instructional outcomes. In R. M. Gagné (Ed.), Instructional technology: Foundations (pp. 343-377). Hillsdale, New Jersey: Lawrence Erlbaum Associates.

Bandura, A. (1997). Self-efficacy: The exercise of control. New York: Freeman.

Barab, S., \& Squire, K. (2004). Design-based research: Putting a stake in the ground. Journal of the Learning Sciences, 13(1), 1-14.

Baxter, J. A., \& Lederman, N. G. (1999). Assessment and measurement of pedagogical content knowledge. In J. Gess-Newsome, \& N. G. Lederman (Eds.), Examining pedagogical content knowledge (pp. 147-162). Norwell, MA: Kluwer Academic Publishers.

Baylor, A. L., \& Ritchie, D. (2002). What factors facilitate teacher skill, teacher morale, and perceived student learning in technology-using classrooms? Computers $\mathcal{E}$ Education, 39(4), 395-414. doi: 10.1016/s0360-1315(02)00075-1

Becker, H. J. (2001). How are teachers using computers in instruction? Paper presented the Annual Meeting of the American Educational Research Association, Seattle, WA.

Blumenfeld, P. C., Marx, R. W., Soloway, E., \& Krajcik, J. (1996). Learning with peers: From small group cooperation to collaborative communities. Educational Researcher, 25(8), $37-40$. 
Borko, H., Whitcomb, J., \& Liston, D. (2008). Wicked problems and other thoughts on issues of technology and teacher learning. Journal of Teacher Education 60(1), 3-7.

Brewer, M. (2000). Research design and issues of validity. In H. Reis, \& C. Judd (Eds.), Handbook of research methods in social and personality psychology. Cambridge University Press.

Brown, D., \& Warschauer, M. (2006). From the university to the elementary classroom: Students' experiences in learning to integrate technology in instruction. Journal of Technology and Teacher Education, 14(3), 599-621.

Bullock, D. (2004). Moving from theory to practice: An examination of the factors that preservice teachers encounter as the attempt to gain experience teaching with technology during field placement experiences. Journal of Technology and Teacher Education, 12(2), 211-237.

Burgoyne, N. (2010). Investigating the reliability and construct validity of a measure of preservice teachers' self-efficacy for TPACK (Unpublished master's thesis). Brigham Young University, Provo, UT.

Burgoyne, N., Graham, C. R., \& Sudweeks, R. (2010). The validation of an instrument measuring TPACK. In D. Gibson, \& B. Dodge (Eds.), Proceedings of Society for Information Technology \& Teacher Education International Conference 2010 (pp. 3787-3794). Chesapeake, VA: AACE.

Chandra-Handa, M. (2001). Leading academic change - through connective leadership and learning. In J. Price et al. (Eds.), Proceedings of Society for Information Technology \& Teacher Education International Conference 2001 (pp. 488-493). Chesapeake, VA: AACE.

Chen, C, H. (2008). Why do teachers not practice what they believe regarding technology integration? The Journal of Educational Research, 102(1), 65-75.

Chen, W., \& Looi, C. (2007). Incorporating online discussion in face to face classroom learning: A new blended learning approach. Australasian Journal of Education Technology, 23(3), 307-326.

Christensen, R. (1998). Effect of technology integration education on the attitudes of teachers and their students (Unpublished doctoral dissertation). University of North Texas, Denton.

Christensen, R., \& Knezek, G. (1996). Constructing the Teachers' Attitudes toward Computers (TAC) questionnaire. Paper presented at the Southwest Educational Research Association Annual Conference, New Orleans, Louisiana.

Christensen, R., \& Knezek, G. (2008). Self-report measures and findings for information technology attitudes and competencies. In J. Voogt, \& G. Knezek (Eds.). International handbook of information technology in primary and secondary education, 397-417. New York: Springer.

Churchill, D. (2009). Educational applications of Web 2.0: Using blogs to support teaching and learning. British Journal of Educational Technology, 40(1), 179-183. doi: 10.1111/j.1467-8535.2008.00865.x

Cohen, J. (1988). Statistical power analysis for the behavioral sciences (2nd ed.). Hillsdale, NJ: Erlbaum. 
Cole, M. (1997). Cultural psychology: A once and future discipline. Cambridge, MA: The Belknap Press of Harvard University Press.

Collis, B., \& Moonen, J. (2001). Flexible learning in a digital world: Experiences and expectations. London: Kogan Page.

Collis, B., Bruijstens, H., \& Van der Veen, J. K. (2003). Course redesign for blended learning: Modern optics for technical professionals. International Journal of Continuing Engineering Education and Lifelong Learning, 13(1/2), 22-38.

Cooper, P., \& McIntyre, D. (1996). Effective teaching and learning. Philadelphia: Open University.

Coppola, E. (2004). Powering up. Learning to teach well with technology. New York: Teachers College Press.

Cox, S. (2008). A conceptual analysis of technological pedagogical content knowledge (Unpublished doctoral dissertation). Brigham Young University, Provo, UT. Retrieved from: http://contentdm.lib.byu.edu/ETD/image/etd2552.pdf

Day, C., Elliot, B., \& Kington, A. (2005). Reform, standards and teacher identity: Challenges of sustaining commitment. Teaching and Teacher Education, 21(5), 563-577.

Delacey, B. J., \& Leonard, D. A. (2002). Case study on technology and distance in education at the Harvard Business School. Educational Technology and Society, 5(2), 13-28.

Delcourt, M. A. B., \& Kinzie, M. B. (1993). Computer technologies in teacher education: The measurement of attitudes and self-efficacy. Journal of Research $\mathcal{E}$ Development in Education, 27, 31-37.

Doering, A., Hughes, J., \& Huffman, D. (2003). Preservice teachers: Are we thinking with technology? Journal of Research on Technology Education, 35, 342-361.

Doering, A., Scharber, C., Miller, C., \& Veletsianos, G. (2009). GeoThentic: Designing and assessing with technology, pedagogy, and content knowledge. Contemporary Issues in Technology and Teacher Education [Online serial], 9(3). Retrieved from http://www.citejournal.org/vol9/iss3/socialstudies/article1.cfm

Doering, A., Veletsianos, G., Scharber, C., \& Miller, C. (2009). Using the Technological, Pedagogical, and Content Knowledge framework to design online learning environments and professional development. Journal of Educational Computing Research, 41(3), 319-346.

Duran, D. (2003). Measurement of attitude toward educational use of the internet in an English composition course with a comparison of traditional aged and non-traditional aged students (PhD dissertation). West Virginia University, USA. Retrieved from http://wvuscholar.wvu.edu:8881//exlibris/dtl/d3_1/apache_media/L2V4bGlicmlz L2R0bC9kM18xL2FwYWNoZV9tZWRpYS82NTI1.pdf

Eagley, A. H., \& Chaiken, S. (1998) Attitude structure and function. In D. T. Gilbert, S. T. Fiske, \& G. Lindzey (Eds.), The handbook of social psychology, $4^{\text {th }}$ ed. (pp. 56-67). McGraw-Hill, New York.

Ertmer, P. (1999). Addressing first- and second-order barriers to change: Strategies for technology integration. Educational Technology Research and Development, 47(4), 47-61. doi: $10.1007 /$ bf02299597 
Ertmer, P. A., \& Ottenbreit-Leftwich, A. T. (2010). Teacher technology change: How knowledge, confidence, beliefs, and culture intersect. Journal of Research on Technology in Education, 42(3), 255-285.

ESCWA. (2003). Profile of the information society in the State of Kuwait 2003. Economic and Social Commission for Western Asia (ESCWA). New York: United Nations. Retrieved from http://www.escwa.un.org/wsis/reports/docs/Kuwait-E.pdf

ESCWA. (2007). National profile of the information society in Kuwait. Economic and Social Commission for Western Asia (ESCWA). New York: United Nations. Retrieved from http:/ /isper.escwa.un.org/LinkClick.aspx?fileticket=c1y3Vur8oFo\%3D\&tabid=220\&la nguage $=$ en-US

ESCWA. (2009) Economic and Social Commission for Western Asia, United Nations Economic and Social Commission for Western Asia publication. Retrieved April 2010, from http://www.escwa.un.org/information/publications/edit/upload/ictd-0912.pdf

ESCWA. (2009). National profile of the information society in Kuwait. Economic and Social Commission for Western Asia (ESCWA). New York: United Nations. Retrieved from http://www.escwa.un.org/wsis/reports/docs/Kuwait-09-E.pdf

Figg, C. B. (2000). Relationships between selected elementary teachers' beliefs and educational technology use (Unpublished dissertation). University of Texas, Austin.

Fishbein, M., \& Ajzen, I. (1972). Attitudes and opinions. Annual Review of Psychology, 23, 487- 544

Fishman, B., \& Davis, E. (2006). Teacher learning research and the learning science. In R. K. Sawyer (Ed.), Cambridge handbook of the learning sciences (pp. 535-550). Cambridge University Press.

Flick, L., \& Bell, R. (2000). Preparing tomorrow's science teachers to use technology: Guidelines for science educators. Contemporary Issues in Technology and Teacher Education, 1(1), 39-60.

Gable, R. K. (1986). Instrument development in the affective domain. Boston: Kluwer-Nijhoff Publishing.

Gable, R. K., \& Wolf, M. B. (1993). Instrument development in the affective domain: Measuring attitudes and values in corporate and school settings (2nd ed.). Boston: Kluwer Academic Publishers.

Gagné, R. M. (1985). The conditions of learning (4th ed.). New York: Holt, Rinehart \& Winston.

Gall, M. D., Gall, J. P., \& Borg, W. R. (2007). Education research: An introduction (8th ed.). Boston: Pearson Education.

Gifford, B. L. (2004). Teacher beliefs, learning styles, and technology implementation in rural, secondary classrooms in Massachusetts (Unpublished doctoral dissertation). Providence, Rhode Island: Johnson and Wales University.

Goodrum, D., Hackling, M., \& Rennie, L. (2001) The status and quality of teaching and learning of science in Australian schools. Canberra: Department of Education, Training and Youth Affairs. 
Graham, C. R. (2006). Blended learning systems: Definition, current trends, and future directions. In C. Bonk, \& C. R. Graham (Eds.), The handbook of blended learning: Global perspectives, local design (pp. 3-21). San Francisco, CA: Pfeiffer.

Graham, C. R., Allen, S., \& Ure, D. (2003). Blended learning environments: A review of the research literature (Unpublished manuscript). Provo, UT.

Graham, C. R., Allen, S., \& Ure, D. (2005). Benefits and challenges of blended learning environments. In M. Khosrow-Pour (Ed.), Encyclopedia of information science and technology (pp. 253-259). Hershey, PA: Idea Group.

Graham, C. R., Burgoyne, N., Cantrell, P., Smith, L., St. Clair, L., \& Harris, R. (2009). TPACK Development in science teaching: Measuring the TPACK confidence of inservice science teachers. TechTrends, 53(5), 70-79.

Green, S. B., \& Salkind, N. J. (2008). Using SPSS for Windows and Macintosh. Analyzing and understanding data (5 $5^{\text {th }}$ ed.). New Jersey Pearson: Prentice Hall.

Handelzalts, A. (2009). Collaborative curriculum development in teacher design teams (Unpublished doctoral thesis). University of Twente, Enschede, The Netherlands.

Harel, I. (1991). Children designers: Interdisciplinary constructions for learning and knowing mathematics in a computer-rich school. Norwood, NJ: Ablex Publishing Corporation.

Harel, I., \& Papert, S. (1991). Constructionism. Norwood, NJ: Ablex Publishing Corporation.

Harris, J., Grandgenett, N. \& Hofer, M. (2010). Testing a TPACK-based technology integration assessment rubric. In D. Gibson, \& B. Dodge (Eds.), Proceedings of Society for Information Technology \& Teacher Education International Conference 2010 (pp. 3833-3840). Chesapeake, VA: AACE.

Harris, J., Mishra, P., \& Koehler, M. (2009). Teachers' Technological Pedagogical Content Knowledge and learning activity types: Curriculum-based technology integration reframed. Journal of Research on Technology in Education, 41(4), 393-416.

Hasselbring, T. S., Smith, L., Glaser, C. W., Barron, L., Risko, V., \& Snyder, C., et al. (2000). Literature review: Technology to support teacher development. Washington, DC: National Partnership for Excellence and Accountability in Teaching.

Haughey, M. (2002). Canadian research on information and communications technologies: A state of the field. Retrieved May 15, 2011 from http:/ / citeseerx.ist.psu.edu/viewdoc/download?doi=10.1.1.84.998\&rep=rep1\&type=pdf

Hicks, T. (2006). Expanding the conversation: A commentary towards revision of Swenson, Rozema, Young, McGrail, and Whitlin. Contemporary Issues in Technology and Teacher Education [Online serial], 6(1). Retrieved from http://www.citejournal.org/vol6/iss1/languagearts/article3.cfm

Hinkelman, D. (2005). Blended learning: Issues driving an end to laboratory-based CALL. JALT Hokkaido Journal, 9, 17-31.

Hoadley, C. (2004). Methodological alignment in design-based research. Educational Psychologist, 39(4), 203-212. 
Hofer, M., Grandgenett, N., Harris, J., \& Swan, K. (2011). Testing a TPACK-based technology integration observation instrument. Paper presented at the Society for Information Technology \& Teacher Education International Conference 2011, Nashville, Tennessee, USA. Retrieved from http:/ / www.editlib.org/p/37015

Hsi, S. (1997). Facilitating knowledge integration in science through electronic discussion: The multimedia forum kiosk (Unpublished doctoral dissertation). University of California, Berkeley. Retrieved from http://www.citejournal.org/vol9/iss1/general/article2.cfm

Huang, H. M., \& Liaw, S. S. (2005). Exploring users' attitudes and intentions toward the web as a survey tool. Computers in Human Behavior, 21(5), 729-743.

Hughes, J. 2004, Technology learning principles for pre-service and in-service teacher education. Contemporary Issues in Technology and Teacher Education, 4(3), 345-362.

Hughes, J. (2005). The role of teacher knowledge and learning experiences in forming technology-integrated pedagogy. Journal of Technology and Teacher Education, 13(2), 277302.

Jaipal, K., \& Figg, C. (2010). Unpacking the "Total PACKage": Emergent TPACK characteristics from a study of preservice teachers teaching with technology. Journal of Technology and Teacher Education, 18(3), 415-441. Chesapeake, VA: AACE.

Jett, D., \& Schafer, W. (1993). High school teachers' attitudes toward a statewide high stakes student performance assessment. Paper presented at the annual meeting of the Educational Research Association, Atlanta, GA.

Jimoyiannis, A. (2008). Factors determining teachers' beliefs and perceptions of ICT in education. In A. Cartelli, \& M. Palma (Eds.), Encyclopaedia of information communication technology (pp. 321-334), Hershey, PA: IGI Global.

Jimoyiannis, A. (2010). Designing and implementing an integrated technological pedagogical science knowledge framework for science teachers professional development. Computers \& Education, 55(3), 1259-1269. doi: 10.1016/ j.compedu.2010.05.022

Kanaya, T., Light, D., \& McMillan Culp, K. (2005). Factors influencing outcomes from a technology-focused professional development program. Journal of Research on Technology in Education, 37(2), 313-329.

Kay, R. (1992). Understanding gender differences in computer attitudes, aptitude, and use: An invitation to build theory. Journal of Research on Computing in Education, 25(2), 159-161.

Kay, R. (2007). A formative analysis of how pre-service teachers learn to use technology. Journal of Computer Assisted Learning, 23(5), 366-383.

Keating, T., \& Evans, E. (2001). Three computers in the back of the classroom: Pre-service teachers' conceptions of technology integration. In J. Price, D. A. Willis, N. Davis, \& J. Willis, (Eds.), Society for Information Technology \& Teacher Education International Conference 2001. Norfolk, VA: AACE.

Keeler, C. (2008). When curriculum and technology meet: Technology integration in methods courses. Journal of Computing in Teacher Education, 25(1), 23-30. 
Kellenberger, D., \& Hendricks, S. (2003). Predicting teachers' computer use for their own needs, teaching, and student learning. Paper presented at the Hawaii International Conference on Education, Honolulu, HI.

Kelly, M. G. (Ed.). (2002). National educational technology standards for teachers: Preparing teachers to use technology (1st ed.). Eugene, OR: International Society for Technology in Education.

Kereluik, K., Casperson, G., \& Akcaoglu, M. (2010). Coding pre-service teacher lesson plans for TPACK. Paper presented at the Society for Information Technology \& Teacher Education International Conference 2010, San Diego, CA, USA.

Kereluik, K., Mishra, P., \& Koehler, M. (2010). Reconsidering the T and C in TPACK: Repurposing technologies for interdisciplinary knowledge. Paper presented at the Society for Information Technology \& Teacher Education International Conference 2010, San Diego, CA, USA. http://www.editlib.org/p/33987

Kersaint, G., Horton, B., Stohl, H., \& Garofalo, J. (2003). Technology beliefs and practices of mathematics education faculty. Journal of Technology and Teacher Education, 11(4), 549-577.

Keys, P. M. (2005). Are teachers walking the walk or just talking the talk in science education? Teachers and Teaching: Theory and Practice, 11(5), 499 - 516.

Kirschner, P., \& Selinger, M. (2003). The state of affairs of teacher education with respect to information and communications technology. Technology, Pedagogy and Education, 12, 5-17.

Knezek, G., \& Christensen, R. (2008). The importance of information technology attitudes and competencies in primary and secondary education. In J. Voogt, \& G. Knezek (Eds.), International handbook of information technology in primary and secondary education (pp. 321-332). New York: Springer.

Koehler, M. J., \& Mishra, P. (2005). What happens when teachers design educational technology? The development of Technological Pedagogical Content Knowledge. Journal of Educational Computing Research. 32(2), 131-152.

Koehler, M. J., \& Mishra, P. (2008). Introducing TPCK. In AACTE (Ed.), Handbook of technological pedagogical content knowledge (TPCK) for educators (pp. 3-29). New York: Routledge.

Koehler, M. J., Mishra, P., \& Yahya, K. (2007). Tracing the development of teacher knowledge in a design seminar: Integrating content, pedagogy and technology. Computers \& Education, 49(3), 740-762. doi: 10.1016/j.compedu.2005.11.012

Koehler, M. J., Mishra, P., Hershey, K., \& Peruski, L. (2004). With a little help from your students: A new model for faculty development and online course design. Journal of Technology and Teacher Education, 12(1), 25-55

Koehler, M., \& Mishra, P. (2009). What is technological pedagogical content knowledge? Contemporary Issues in Technology and Teacher Education, 9(1), pp. 60-70.

Kozma, Robert B. (Ed.). (2003). Technology, innovation, and educational change: A global perspective. Eugene, OR: International Society for Technology in Education.

Krajcik, J. S., Blumenfeld, P., Marx, R. W., Bass, K. M., Fredricks, J., \& Soloway, E. (1998). Middle school students' initial attempts at inquiry in project-based science classrooms. The Journal of the Learning Sciences, 7, 313-350.

Krathwohl, D. R., Bloom, B. S., \& Masia, B. B. (1964). Taxonomy of educational objectives, handbook II: Affective domain. New York: McKay. 
Kruse, S. D., \& Louis, K. S. (1997). Teacher teaming in middle schools: Dilemmas for a schoolwide community. Educational Administration Quarterly, 33(3), pp.261-289.

Landis, J. R., \& Koch, G. G. (1977). The measurement of observer agreement for categorical data. Biometrics, 33(1), 159-174.

Landry, G. A. (2010). Creating and validating an instrument to measure middle school mathematics teachers' Technological Pedagogical Content Knowledge (TPACK) (PhD dissertation). University of Tennessee. Retrieved from http:/ / trace.tennessee.edu/utk_graddiss/720 on 29-5-2011

Lawless, K. A., \& Pellegrino, J. W. (2007). Professional development in integrating technology into teaching and learning: Knowns, unknowns, and ways to pursue better questions and answers. Review of Educational Research, 77(4), 575-614. doi: 10.3102/0034654307309921

Levine, T., \& Schmidt, S. (1998). Computer use, confidence, attitudes, and knowledge: A causal analysis. Computers in Human Behavior, 14, 125-146.

Liaw, S. (2000). Information technology and education: Student perceptions of computer and Webbased environments (Doctoral dissertation). Seattle Pacific University.

Littlejohn, A., \& Pegler, C. (2007). Preparing for blended e-learning. London: Routledge.

Lundeberg, M., Bergland, M., Klyczek, K., \& Hoffman, D. (2003). Using action research to develop preservice teachers' beliefs, knowledge and confidence about technology. Journal of Interactive Online Learning, 1(4). Retrieved February, 2011, from http://www.ncolr.org/jiol/issues/pdf/1.4.5.pdf

MacDonald, R. J. (2008). Professional development for information communication technology integration: Identifying and supporting a community of practice through design-based research. Journal of Research on Technology in Education, 40(4), 429-445.

Margerum-Leys, J., \& Marx, R. (2002). Teacher knowledge of educational technology: A study of student teacher/mentor teacher pairs. Journal of Educational Computing Research, 26(4), 427-462.

Margrum-Leys, J., \& Marx, R. W. (2003). Teacher knowledge of educational technology: A case study of student/mentor teacher pairs. In Y. Zhao (Ed.), What should teachers know about technology: Perspectives and practices. Greenwich: CT: Information Age Publishing.

Marsh, D. (1994). Change in schools: Lessons from the literature. In S. A. Mohrman, \& P. Wohlstetter (Eds.), School-based management: Organizing for high school performance (pp. 215-251). California: Jossey-Bass Inc.

Masie, E. (2002). Blended learning: The magic is in the Mix. In A. Rossett (Ed.), The ASTD elearning handbook (pp. 58-63). New York: McGraw-Hill.

McCrory, R. (2008). Science, technology, and teaching: The topic-specific challenges of TPCK in science. In AACTE (Ed.), Handbook of Technological Pedagogical Content Knowledge (TPCK) for Educators (pp. 193-206). Routledge: Taylor \& Francis Group.

McKenney, S., \& Reeves, T. (in press). Conducting educational design research. London: Routledge.

McKenney, S., Nieveen, N., \& van den Akker, J. (2006). Design research from the curriculum perspective. In J. Van den Akker, K. Gravemeijer, S. McKenney, \& N. Nieveen (Eds.), Educational Design Research, pp. 67-90. London: Routledge. 
Milbrath, Y. C. L., \& Kinzie, M. B. (2000). Computer technology training for prospective teachers: Computer attitudes and perceived self-efficacy. Journal of Technology and Teacher Education, 8(4), 373-396.

Milken Exchange on Educational Technology Report. (1999). Will new teachers be prepared to teach in a digital age? A national survey on information technology in teacher education. Retrieved on 22 June 2009. Available at http://www.milkenexchange.org/research/iste_results.html

Ministry of Education. (2008). The e-learning strategy (report). Kuwait.

Mishra, P., \& Koehler, M. J. (2003). Not "what" but "how": Becoming design-wise about educational technology. In Y. Zhao. (Ed.), What teachers should know about technology: Perspectives and practices (pp. 99-122). Greenwich, CT: Information Age Publishing.

Mishra, P., \& Koehler, M. (2006). Technological Pedagogical Content Knowledge: A new framework for teacher knowledge. Teachers College Record 108(6), 1017-1054..

Mishra, P., \& Koehler, M. (2007). Technological Pedagogical Content Knowledge (TPCK): Confronting the wicked problems of teaching with technology. In C. Crawford et al. (Eds.), Proceedings of Society for Information Technology and Teacher Education International Conference 2007 (pp. 2214-2226). Chesapeake, VA: Association for the Advancement of Computing in Education.

Mishra, P. \& Koehler. M. J. (2009). Too cool for school? No way! Using the TPACK framework: You can have your hot tools and teach with them, too. Learning $\mathcal{E}$ Leading with Technology, 36(7), 14-18.

Mishra, P., Koehler, M. J., \& Kereluik, K. (2009). The song remains the same: Looking back to the future of educational technology. TechTrends, 53(5), 48-53.

Mishra, P., Koehler, M., \& Zhao, Y. (Eds.). (2007). Faculty development by design: Integrating technology in higher education. Greenwich, CT: Information Age Publishing.

Mishra, P., Peruski, L., \& Koehler, M. (2007). Developing Technological Pedagogical Content Knowledge (TPCK) through teaching online. In R. Carlsen, et al. (Eds.), Proceedings of Society for Information Technology \& Teacher Education International Conference 2007 (pp. 2208-2213). Chesapeake, VA: AACE.

Moore, M. G. (2002). What does research say about the learners using computer-mediated communication in distance learning? American Journal of Distance Education, 16(2), 6581.

Moursund, D., \& Bielefeldt, T. (1999). Will new teachers be prepared to teach in a digital age? A national survey on information technology in teacher education. Santa Monica, CA: Milken Family Foundation.

Mumtaz, S. (2000). Factors affecting teachers' use of information and communications technology: A review of the literature. Journal of Information Technology for Teacher Education, 9(3), 319-341.

Myers, J. M., \& Halpin, R. (2002). Teachers' attitudes and use of multimedia technology in the classroom: Constructivist-based professional development training for school districts. Journal of Computing in Teacher Education, 18(4), 133-140.

National ICT in Education Strategy. (2008, Feb). Paper presented in the National Conference for the Development of Education. Kuwait.

Neo, M. (2005). Engaging students in group-based learning - A Malaysian perspective. Educational Technology \& Society, 8(4), 220-232. 
Neumeier, P. (2005). A closer look at blended learning - parameters for designing a blended learning environment for language teaching and learning. ReCALL, 17(2), 163 178. doi:10.1017/S0958344005000224

Niess, M. L. (2005). Preparing teachers to teach science and mathematics with technology: Developing a technology pedagogical content knowledge. Teaching and Teacher Education, 21(5), 509-523.

Niess, M. L. (2008). Guiding pre-service teachers in developing TPCK. In AACTE Committee on Innovation and Technology (Ed.), Handbook of technological pedagogical content knowledge (TPCK) for educators, (pp. 223-251). New York: Routledge.

Nieveen, N., Handelzalts, A., \& Van den Akker, J. (2005). Teacher design teams in view of school-based curriculum development. Paper presented at the American Educational Research Association Annual Meeting, Montreal.

Oster-Levinz, A., \& Klieger, A. (2010). Online tasks as a tool to promote teachers' expertise within the Technological Pedagogical Content Knowledge (TPACK). Procedia - Social and Behavioral Sciences, 2(2), 354-358. doi: 10.1016/j.sbspro.2010.03.024

PAAET (2010).The college of basic education. Public authority of applied education and training. Retrieved from http://www.paaet.edu.kw/old/faculty-e.htm\#cbe

Palak, D., \& Walls, R. T. (2009). Teachers' beliefs and technology practices: A mixedmethods approach. Journal of Research on Technology in Education, 41(4), 417-441.

Papert, S. (1987). Computer criticism vs. technocentric thinking. Educational Researcher, $16(1), 22-30$.

Pierson, M. E. (2001). Technology integration practice as a function of pedagogical expertise. Journal of Research on Computing in Education, 33, 413-429.

Potosky, D., \& Bobko, P. (2001). A model for predicting computer experience from attitudes toward computers. Journal of Business and Psychology, 15(3), 391-404.

Reeves, T. C. (2000). Enhancing the worth of instructional technology research through design experiments' and other development research strategies. Paper presented at the Annual Meeting of the American Educational Research Association New Orleans, LA, USA Retrieved December 24, 2009, from http:/ /it.coe.uga.edu/ treeves/AERA2000Reeves.pdf

Reinking, D., \& Bradley, B. (2008). Formative and design experiments: Approaches to language and literacy research. New York: Teachers College Press.

Riel, M., \& Becker, H. (April 26, 2000). The beliefs, practices, and computer use of teacher leaders. Paper presented at the American Educational Research Association, New Orleans. http://www.crito.uci.edu/tlc/findings/aera/aera_leaders.pdf

Robertshaw, M. B., \& Gillam, R. B. (2010). Examining the validity of the TPACK framework from the ground up: Viewing technology integration through teachers' eyes. In D. Gibson, \& B. Dodge (Eds.), Proceedings of the Society for Information Technology \& Teacher Education International Conference 2010 (pp. 3926-3931). Chesapeake, VA: AACE.

Ropp, M. M. (1999). Exploring individual characteristics associated with learning to use computers in pre-service teacher preparation. Journal of Research on Computing in Education, 31(4), 402-424. 
Sale, D. (2009). What is effective blended learning? Retrieved from http://www.dennissale.com/wp-content/uploads/2009/03/what-is-effectiveblended-learning2.doc

Sandoval W. A., \& Bell P. L. (2004). Design-based research methods for studying learning in context: Introduction. Educational Psychologist, 39, 199-201.

Sang, G., Valcke, M., Braak, J., \& Tondeur, J. (2010). Student teachers' thinking processes and ICT integration: Predictors of prospective teaching behaviours with educational technology. Computers \& Education, 54, 103-112.

Savoy, A., Proctor, R. W., \& Salvendy, G. (2009). Information retention from PowerPoint(TM) and traditional lectures. Computers \& Education, 52(4), 858-867. doi: 10.1016/j.compedu.2008.12.005

Schmidt, D., Baran, E., Thompson, A., Koehler, M. J., Shin, T., \& Mishra, P. (2009, April). Technological pedagogical content knowledge (TPACK): The development and validation of an assessment instrument for preservice teachers. Paper presented at the 2009 Annual Meeting of the American Educational Research Association. April 13-17, San Diego, California. Retrieved from http://mkoehler.educ.msu.edu/unprotected_readings/TPACK_Survey/Schmidt_et_ al_Survey_v1.pdf

Schmidt, D., Baran, E., Thompson, A., Koehler, M., Shin, T., \& Mishra, P. (2009). Technological Pedagogical Content Knowledge (TPACK): The development and validation of an assessment instrument for preservice teachers. Journal of Research on Technology in Education, 42(2), 123-149.

Schrader, P. G., \& Lawless, K. A. (2004). The knowledge, attitudes, \& behaviors approach how to evaluate performance and learning in complex environments. Performance Improvement, 43(9), 8-15. Doi: 10.1002/pfi.4140430905

Selinger, M. (2001). Learning information and communications technology skills and the subject context of the learning. Journal of Information Technology for Teacher Education, 10 (1 \& 2), 143-154.

Shavelson, R., Riiz-Primo, A., Li, M., \& Ayala, C. (2003). Evaluating new approaches to assessing learning (CSE Report 604). Los Angeles, CA: University of California, National Center for Research on Evaluation.

Shin, T., Koehler, M., Mishra, P., Schmidt, D., Baran, E., \& Thompson, A. (March 2009). Changing Technological Pedagogical Content Knowledge (TPACK) through course experiences. Paper presented at the 2009 International Conference of the Society for the Information and Technology \& Teacher Education, Charleston, South, retrieved 15 October 2010, Available at http://punya.educ.msu.edu/publications/Shin_et_al_SITE2009.pdf

Shulman, L. (1987). Knowledge and teaching: Foundations of the new reform. Harvard Educational Review, 57(1), 1-22.

Sime, D., \& Priestley M. (2005). Student teachers' first reflections on information and communications technology and classroom learning: Implications for initial teacher education. Journal of Computer Assisted Learning, 21(2), 130-142. 
Simmie, G. (2007). Teacher Design Teams (TDTs) - building capacity for innovation, learning and curriculum implementation in the continuing professional development of in-career teachers. Irish Educational Studies, 26(2), 163-176.

So, H., \& Brush, T. (2008). Student perceptions of collaborative learning, social presence and satisfaction in a blended learning environment: Relationships and critical factors. Computers \& Education, 51(1), 318-336.

So, H. J., \& Kim, B. (2009). Learning about problem based learning: Student teachers integrating technology, pedagogy and content knowledge. Australasian Journal of Educational Technology, 25(1), 101-116.

Suharwoto, G. (2006). Secondary mathematics pre-service teachers' development of technology pedagogical content knowledge in subject-specific, technology-integrated teacher preparation program (Unpublished doctoral dissertation). Oregon State University, Corvallis.

Summers, M. (1990). New student teachers and computers: An investigation of experiences and feelings. Educational Review, 42, 261-271.

Supovitz, J. A., \& Turner, H. M. (2000). The effects of professional development on science teaching practices and classroom culture. Journal of Research in Science Teaching, 37(9), 963-80.

Szabo, Z., \& Schwartz, J. (2011). Learning methods for teacher education: The use of online discussions to improve critical thinking. Technology, Pedagogy and Education, 20(1), 79-94.

Tabak, I. (2004). Reconstructing context: Negotiating the tension between exogenous and endogenous educational design. Educational Psychologist 39(4), 225- 233.

Tearle, P. (2003). ICT implementation: What makes the difference? British Journal of Educational Technology, 34(5), 567-583.

Teo, T., Lee, C., \& Chai, C. (2008). Understanding pre-service teachers' computer attitudes: Applying and extending the technology acceptance model. Journal of Computer Assisted Learning, 24, 128-143.

Thomson, \& NETg. (2003). The next generation of corporate learning: Achieving the right blend. Retrieved from www.netg.com/NewsAndEvents/PressReleases/view.asp?PressID=75\#top

Thurstone, L. L., \& Chave, E. J. (1929). The measurement of attitude: A psychophysical method and some experiments with a scale for measuring attitude toward the church. The University of Chicago Press

Tschannen-Moran, M., \& Hoy, A. (2001). Teacher efficacy: Capturin an elusive construct. Teaching and Teacher Education, 17, 783-805.

Tsitouridou, M., \& Vryzas, K. (2003). Early childhood teachers' attitudes towards computer and information technology: The case of Greece. Information Technology in Childhood Education Annual, 1, 187-207.

Valanides, N., \& Angeli, C. (2006). Preparing preservice elementary teachers to teach science through computer models. Contemporary Issues in Technology and Teacher Education - Science, 6(1), 87-98.

Valanides, N., \& Angeli, C. (2008). Learning and teaching about scientific models with a computer-modeling tool. Computers in Human Behavior, 24(2), 220-233. doi: 10.1016/j.chb.2007.01.005 
Van Aken, (2004). Management research based on the paradigm of the design sciences: The quest for field-tested and grounded technological rules. Journal of Management Studies 41(2), 219-246.

Van Dijk, E. M., \& Kattmann, U. (2007). A research model for the study of science teachers' PCK and improving teacher education. Teaching and Teacher Education, 23(6), 885-897.

Van Driel, J. H., Jong, O. D., \& Verloop, N. (2002). The development of preservice chemistry teachers' pedagogical content knowledge. Science Education, 86(4), 572-590. Doi: 10.1002/sce. 10010

Vannatta, R. A., \& Fordham, N. (2004). Teacher dispositions as predictors of classroom technology use. Journal of Research on Technology in Education, 36(3), 253-271.

Voogt, J., Almekinders, M., Van den Akker, J., \& Moonen, B. (2005). A 'blended' in-service arrangement for classroom technology integration: Impacts on teachers and students. Computers in Human Behavior, 21, 523-539.

Voogt, J., Tilya, F., \& Van den Akker, J. (2009). Science teacher learning of MBL-supported student-centered science education in the context of secondary education in Tanzania. Journal of Science Education and Technology, 18(5), 429-438.

Vygotsky, L. S. (1978). Mind in society: The development of higher psychological processes. Cambridge, MA: Harvard University Press.

Waddoups, G. L., Wentworth, N., \& Earle, R. (2004). Principles of technology integration and curriculum development: A faculty design team approach. Computers in the Schools, 21(1/2), 15-23.

Wang, C.-h., Ke, Y.-T., Wu, J.-T., \& Hsu, W.-H. (2011). Collaborative action research on technology integration for science learning. Journal of Science Education and Technology, 1-8. doi: 10.1007/s10956-011-9289-0

Wang, F., \& Hannafin, M. (2005). Design-based research and technology-enhanced learning environments. Educational Technology Research and Development, 53(4), 5-23. doi: $10.1007 /$ bf02504682

Watson, D. (1998). Blame the technocentric artifact! What research tells us about problems inhibiting teacher use of IT. In G. Marshall, \& M. Ruohonen (Eds.), Capacity building for IT in education in developing countries (pp. 185-192). London: Chapman \& Hall.

Watson, J. M. (1998). Professional development for teachers of probability and statistics: Into an era of technology. International Statistical Review, 66(3), 271-289.

Webb, M., \& Cox, M. (2004). A review of pedagogy related to information and communications technology. Technology, Pedagogy and Education, 13(3), 235 - 286.

Wetzel, K., Wilhelm, L., \& Williams, M.K. (2004). The introductory technology course: A tool for technology integration. Contemporary Issues in Technology and Teacher Education [Online serial], 3(4). Retrieved from http://www.citejournal.org/vol3/iss4/general/article4.cfm

Williams, M. K., Foulger, T., \& Wetzel, K. (2010). Aspiring to reach $21^{\text {st }}$ century ideals: Teacher educators' experiences in developing their TPACK. In D. Gibson, \& B. Dodge (Eds.), Proceedings of Society for Information Technology \& Teacher Education International Conference 2010 (pp. 3960-3967). Chesapeake, VA: AACE. 
Woodrow, J. (1991). Teachers' perceptions of computer needs. Journal of Research on Computing in Education, 23(4), 475-493.

Yang, H., \& Chen, P. (2010). Building teachers' TPACK through WebQuest development and blended learning process. In P. Tsang, S. Cheung, V. Lee, \& R. Huang (Eds.), Hybrid Learning, 6248, 71-81). Berlin: Springer.

Zakaria, E., \& Iksan, Z.. (2006). Promoting cooperative learning in ecience and Mathematics Education: A Malaysian perspective. Eurasia. Journal of Mathematics, Science $\mathcal{E}$ Technology Education, 3(1), 35-39

Zhao, Y. (Ed.). (2003). What teachers should know about technology? Perspectives and practices. Greenwich, CT: Information Age Publishing.

Zhao, Y., \& Bryant, F. L. (2006). Can teacher technology integration training alone lead to high levels of technology integration? A qualitative look at teachers' technology integration after state mandated technology training. Electronic Journal for the Integration of Technology in Education, 5, 53-62.

Zhao, Y., \& Cziko, G. A. (2001). Teacher adoption of technology: A perceptual control theory perspective. Journal of Technology and Teacher Education, 9(1), 5-30.

Zhao, Y., Pugh, K., \& Sheldon, S. (2002). Conditions for classroom technology innovations. Teachers College Record, 104(3), 482-515.

Zhao, Y., Tan, H. S., \& Mishra, P. (2001). Teaching and learning: Whose computer is it? Journal of Adolescent \& Adult Literacy, 44(4), 348-354.

Zhou, G., Zhang, Z., Li, Y., \& Zhao, Z. (2010). Are secondary preservice teachers wellprepared to teach with technology? A case study of a Chinese teacher education program. In J. Herrington, \& B. Hunter (Eds.), Proceedings of the World Conference on Educational Multimedia, Hypermedia and Telecommunications 2010 (pp. 2291-2300). Chesapeake, VA: AACE.

Zimbardo, P. G., Ebbesen, E. B., \& Maslach, C. (1977). Influencing attitudes and changing behavior: An introduction to method, theory, and applications of social control and personal power. New York, Random House. 


\section{ENGLISH SUMMARY \\ Developing pre-service teacher competencies for ICT integration through Design Teams}

With the steady increase of computers in schools and the opportunities that this brings for education, there is an increasing need to understand the competencies (knowledge, skills and attitudes) that are required by teachers for successful ICT integration in education. Teacher preparation programs are now providing their students with a variety of ICT tools and opportunities to learn and practice ICTrelated skills; however, many studies report that graduates from teacher preparation programs are unable to integrate ICT into their teaching practices. This is most apparent in programs that focus on the acquisition of basic ICT skills through stand-alone courses. Meaningful use of ICT in education requires that teachers develop the knowledge that enables them to integrate ICT with a suitable pedagogical approach for teaching specific subject matter in a certain context. This integrated knowledge is referred to as 'Technological Pedagogical Content Knowledge' (TPACK). TPACK is based on Shulman's $(1986,1987)$ notion of Pedagogical Content Knowledge (PCK). Figure 1 is a graphical representation of the conceptual framework. One strategy for developing TPACK is through 'learning technology by design' by working in Design Teams (DTs).

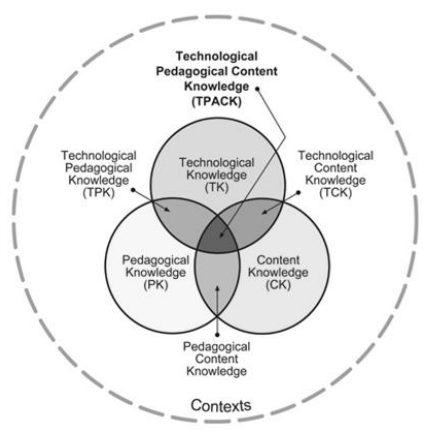

Figure 1 The TPACK framework (adopted from Koehler \& Mishra, 2008) 
The context of this study was the teacher preparation program at the Public Authority of Applied Education \& Training (PAAET) in Kuwait. The teacher preparation program, and in particular the science teacher preparation program at PAAET on which this study focuses, includes some courses on ICT skills, but only as stand-alone ICT skills courses, based on the assumption that acquiring ICT skills will lead automatically to effective integration of ICT by pre-service teachers into their future classroom practices. In this study, pre-service science teachers studying at the science teacher preparation program at PAAET collaborated in Design Teams (DTs) to design curriculum materials and subsequently develop their competencies for ICT integration, including their TPACK.

This research aimed to prepare pre-service science teachers at PAAET for ICT integration. Based upon this research aim, a general question was developed to serve as the overall research question for this project:

"What are the effects of working in DTs on the knowledge, skills and attitudes pre-service teachers need to be able to integrate ICT into their future teaching practice?"

From the main research question, the following four sub-questions were derived:

1. What are the perceptions, attitudes, and needs of pre-service teachers in relation to ICT integration, and what are the conditions for successful usage of ICT at PAAET?

2. What changes could be observed in Technological Pedagogical Content Knowledge (TPACK), ICT skills, and attitudes toward ICT of pre-service science teachers who participated in DTs?

3. What differential effects do Human Support and Blended Support have on pre-service teachers' development of TPACK, and their attitude and skills related to ICT?

4. What TPACK learning outcomes do pre-service teachers demonstrate after working in DTs on ICT integration and how are these TPACK learning outcomes related to their self-reported TPACK?

This project adopted a design-based research, a systematic method that is characterized by observing and addressing complex problems in their natural setting with the aim of improving educational practice through iterative cycles of analysis, design, development, and implementation. 
In response to the first sub-question, 'What are the perceptions, attitudes, and needs of pre-service teachers in relation to ICT integration and what are the conditions for successful usage of ICT at PAAET?', a feasibility, perceptions and attitude study was conducted to inform and support the development of ICT integration in the science teacher preparation program. From previous studies (e.g. Albirini, 2006; Baylor \& Ritchie, 2002; Knezek \& Christensen, 2008), numerous factors are known to affect the use of computers in the classroom. Teachers' attitudes toward computers are directly related to their use of computers in the classroom, are critical for the adoption of ICT in the classroom and for personal use, and determine the success or failure of the introduction of ICT to the classroom. Assessing teachers' attitudes toward ICT use may provide useful insights into the process of ICT integration, ICT acceptance, and ICT usage in teaching and learning; furthermore, it could be a good predictor for teachers' future use of ICT. In addition, teachers' ICT skills are a significant predictor of their attitudes toward computers, and studies have shown that although many teachers believe computers are important tools for education, they avoid using computers in their instruction because they lack confidence about computer use due to lack of knowledge and skills. Therefore, the perceptions of pre-service science teachers at PAAET regarding the current curriculum - especially in relation to ICT, their attitudes toward ICT, skills of ICT use, and their ICT training needs - were assessed. Pre-service science teachers at PAAET reported having a positive attitude toward ICT, basic ICT skills and an awareness of ICT and its potential role in education, but this study also found that they were unsure about their ability to integrate ICT into their teaching. They did not consider themselves to be ICT-integrating teachers, and this was attributed to the following reasons: 1) the ICT-focused courses do not provide students with the ability to integrate ICT in practice; 2) there is limited ICT integration throughout the program, so the preservice teachers do not experience authentic use of ICT in teaching and learning; and 3) there was a predominance of traditional teaching methods throughout their preparation program at PAAET. Based on these results, and on a review of the literature, suggestions to support pre-service teachers to better understand and experience the role ICT in education were proposed with the following goals: 1) to help pre-service teachers understand how student-centred practices, supported by ICT, impact student learning; 2) to provide pre-service teachers with concrete examples of what teaching with ICT looks like in practice and to facilitate change in teachers' knowledge and attitudes about ICT; 3) to provide pre-service teachers with opportunities to explore and experiment with the 
pedagogical uses of ICT tools to help pre-service teachers become more confident about integration; and 4) to work in an authentic, collaborative learning environment as a suitable strategy whereby to prepare pre-service teachers to integrate ICT into their future practices. The results of this study provided adequate input for the second study in which promising directions for the integration of ICT into the science teacher preparation program at PAAET are discussed and designed.

For the purpose of answering the second sub-question, 'What changes could be observed in Technological Pedagogical Content Knowledge (TPACK), ICT skills, and attitudes toward ICT of pre-service science teachers who participated in Design Teams?', a pilot test for TPACK and Design Teams (DTs) was conducted. This study aimed to identify pre-service science teachers' development of TPACK through DTs. It was expected that by working in a DT, the pre-service science teacher would experienced student-centred practices through an authentic, active and collaborative learning environment. Designing an ICT-enhanced lesson would give pre-service science teachers ample opportunities to explore and experiment with ICT tools, to experience the pedagogical uses of ICT tools, to understand what teaching with ICT will look like in practice and how integration of ICT in science curriculum will impact student learning, and to provide pre-service science teachers with concrete examples of effective ICT integration in science education. The whole experience will support the development of competencies needed by pre-service science teachers for ICT integration.

In this second study, DTs were formed to design an ICT-enhanced solution for an authentic educational problem related to the primary science curriculum. The DTs were coached by experts in ICT, content, and pedagogy. During the design process, pre-service science teachers developed their ICT skills and started thinking about ICT as a tool for achieving instructional objectives, rather than as an end in itself. Each pre-service teacher became an active learner, collaborated with different team members, learned by doing, and experimented with different kinds of ICT tools to solve the pedagogical problems they encountered. This study provided pre-service science teachers at PAAET with the competencies required of an ICT-integrating teacher. The results of the second study showed that the ICT skills of the pre-service teachers increased significantly after they had worked in DTs on developing or designing a solution for a problem related to the specific science content by utilizing a suitable pedagogy and appropriate 
ICT tools. The pre-service teachers developed a positive attitude toward both ICT and teamwork, and their TPACK had increased after working in DTs. This meant that the pre-service teachers had positive experiences with using ICT and gained ICT-related skills. Additionally, at the end of the intervention, the pre-service teachers reported an increase in the usefulness and ease of ICT use, which suggested that the pre-service teachers increased their confidence and competence in using ICT.

The findings provided evidence that working in a DT fostered the development of TPACK, which is the knowledge needed by pre-service teachers for ICT integration in their practices.

Significantly, experts who coached the pre-service science teachers indicated that the face-to-face support they provided DTs during the course was essential in routing students' thinking toward TPACK; however, both the experts and the pre-service science teachers acknowledged that face-to-face support was timeconsuming and asked for more flexibility related to time and delivery, as an important feature of an environment supportive of TPACK development. In addition to flexibility, the pre-service teachers stressed a need for a support system or environment in the Arabic language. Since students at the PAAET teacher preparation program are used to a teacher-centred approach to learning, an online environment that completely replaces the support of the expert instructors might not be an effective strategy. For this reason, a blended approach to support the DTs was chosen for exploration in the third study.

From the findings of the second study, a third sub-question was formulated, 'What differential effects do Human Support and Blended Support have on pre-service teachers' development of TPACK, and their attitude and skills related to ICT?', to explore whether providing Blended Support (online support integrated with face-to-face support from expert instructors) for learning could be an effective and efficient alternative way to support the development of TPACK in the preservice science teachers while working in DTs. It could also confirm the findings of the previous study that working in DTs to design an ICT-enhanced lesson is a promising way to foster the development of TPACK in pre-service science teachers at PAAET. Two kinds of support were distinguished: human and online. The human support was provided by the different experts on pedagogy, science/math content and ICT. The blended support was provided via an online 
support portal in Moodle, containing tutorials on how to use different kinds of software, examples of lesson plans that integrate ICT, a matrix of different ICT applications with suitable teaching methods, and examples or URL links on the use of ICT in science/math education. The portal also offered online expert support through a chat tool, a workplace for DTs to share documents, a discussion forum to reflect on classes, and a forum for responding to a weekly question. Besides using the portal, the pre-service students in the Blended support condition had the opportunity to consult the experts face-to-face. The third study found that both the human support and blended support condition showed significant positive effects on teacher's attitude, knowledge, and skills needed for ICT integration. This led to the conclusion that the human support and the blended support conditions are successful alternatives for supporting pre-service teachers. Blended support, however, showed higher gains in attitudes toward ICT, Technological Pedagogical Knowledge (TPK), and Technological Knowledge (TK). No differences were found between the two conditions in terms of the anxiety and frustration toward computers, ICT skills (test and survey) and - except for TK and TPK - the other aspects of TPACK. Based on the findings of this study, it was concluded that applying the DT approach combined with the Blended Support approach is beneficial for pre-service teachers and the instructors that guide them. The pre-service teachers showed higher gains in attitudes toward ICT, TPK and TK; they gained more experience with ICT use; and they experienced a student-centred approach. For the instructors, the Blended Support for Learning meant an effective and, above all, more efficient way of supporting the pre-service teachers.

To answer the fourth sub-question, 'What TPACK learning outcomes do pre-service teachers demonstrate after working in Design Teams on ICT integration and how are these TPACK learning outcomes related to their self-reported TPACK?', a study was conducted to assess pre-service teachers' TPACK. Furthermore, this studied examined which TPACK learning outcomes the pre-service teachers demonstrated after working in DTs on ICT integration and whether the learning outcomes of the pre-service teachers were related to their self-reported TPACK. What the students learned about TPACK was determined through a diversity of measures. Therefore, to uncover and understand more of the complexity inherent to the situatedness of the TPACK construct, this study addressed a mixedmethod assessment of teachers' ICT integration knowledge, specifically focusing on teachers' perceptions (i.e. self-reports), as opposed to their learning outcomes 
as demonstrated in a lesson plan, the ICT product, the TPACK definition and reflection questions, and the ICT skills test. Based on the results related to the TPACK learning outcomes, the fourth study demonstrated that the pre-service teachers were able to develop an ICT-enhanced product and to integrate this product into a lesson plan that aimed to solve a problem related to teaching science or mathematics in primary school. The pre-service teachers were able to define TPACK and to describe a situation to express that they can use the TPACK framework to teach a topic related to primary school science or mathematics. They were also able to present their product to peers and instructors and defend their choice of ICT tool, design-related issues (e.g. consistency, contrast, balance, colour scheme), and pedagogy. Furthermore, they were able to build their argument using the different domains of TPACK. The study also showed that pre-service teachers' ICT skills increased significantly after working in DTs. The findings indicated that pre-service teachers were able to demonstrate their TPACK understanding at various knowledge levels: declarative, procedural, schematic and strategic. Based on the pre-test of the TPACK survey, the correlation among the different TPACK domains were small, medium or nonexistent. In other words, the pre-service teachers did not integrate the different knowledge areas into their thinking about ICT integration in education. This indicates that the pre-service teachers' self-assessment of TPACK was superficial or incomplete before the intervention started; however, the correlation among the post-test measure of the TPACK survey showed significant positive correlations between TK, PK, CK and their intersections. This indicated that the pre-service teachers' self-assessment of their understanding of TPACK had developed; however, a closer inspection of the data revealed no correlations between the selfreported findings and TPACK learning outcomes. This indicates that the students' perception of their own TPACK development was not necessarily aligned with the their ability to demonstrate the integration of ICT, pedagogy and content in practice. This unexpected finding questioned the validity of the way in which TPACK was measured in the TPACK survey. The survey asks the pre-service teachers to report on their TPACK in a general and abstract way. In order to more accurately measure an individual's TPACK through selfassessment, the survey should be tailored to the particular educational practice of the person being asked to complete the survey. This implies that the instrument should be more specific about the way in which specific ICT tools could help to prevent the development of misconceptions in students. This problem with the TPACK survey may be due to the fact that the definition of the TPACK construct 
is still quite vague. The main goal of this study was to prepare pre-service teachers for ICT integration in teaching and learning. For this reason, the learning outcomes that the pre-service teachers demonstrated better showed their ability to integrate ICT in teaching and learning, and therefore serve as a better indicator of their TPACK than the TPACK survey.

In general, this research indicated that the strategy of utilizing TPACK and working in DTs were successful in developing pre-service teachers' ability for ICT integration. Furthermore, this strategy provides a theoretical and practical basis for ICT integration in teachers' preparation program, especially in science teacher preparation at PAAET in Kuwait. 


\section{NEDERLANDSE SAMENVATTING \\ De ontwikkeling van competenties voor ICT integratie bij studenten aan een lerarenopleiding door middel van Design Teams}

Door de gestage toename van computers in scholen, en de mogelijkheden die dat met zich meebrengt voor het onderwijs, wordt de behoefte steeds groter om de competenties (kennis, vaardigheden en attitudes), die leraren nodig hebben voor succesvolle integratie van ICT in het onderwijs, te begrijpen. Opleidingsprogramma's voor leraren bieden studenten nu een grote verscheidenheid aan ICT-hulpmiddelen en mogelijkheden om ICT-gerelateerde vaardigheden aan te leren en om ermee te oefenen. Veel onderzoeken wijzen echter uit dat afgestudeerden van leraren-opleidingsprogramma's niet in staat zijn om ICT in hun onderwijspraktijk te integreren. Dit valt het meest op bij opleidingsprogramma's die gericht zijn op het aanleren van basale ICT vaardigheden door op-zichzelf staande, losse cursussen. Voor betekenisvol gebruik van ICT in het onderwijs is het nodig dat leraren de kennis ontwikkelen die hen in staat stelt ICT te integreren met een geschikte didactische benadering voor het onderwijzen van specifieke onderwerpen in een bepaalde context. Deze geintegreerde kennis wordt ook wel 'Technological Pedagogical Content Knowledge' (TPACK) genoemd. TPACK is gebaseerd op Shulman's (1987) denken over Pedagogical Content Knowledge (PCK). Figuur 1 is een grafische representatie van het conceptuele model. Een mogelijke strategie voor het aanleren van TPACK is het gebruik van 'Learning Technology by Design', door te werken in ontwerpteams, ofwel Design Teams (DTs). 


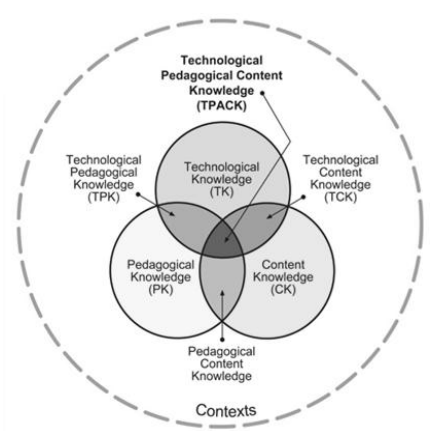

Figuur 1 Het TPACK conceptuele model (bron:Koehler \& Mishra, 2008)

De context van dit onderzoek bestond uit het leraren-opleidingsprogramma van de Public Authority of Applied Education \& Training (PAAET) in Koeweit. PAAET leidt studenten op tot docent basisonderwijs. Het huidige opleidingsprogramma, en vooral het opleidingsprogramma voor science onderwijs (in Nederland exacte vakken genoemd) aan de PAAET waar dit onderzoek zich op richt, bevat enkele cursussen voor ICT vaardigheden, maar alleen als op-zichzelf staande ICT vaardigheidscursussen, gebaseerd op de aanname dat het opdoen van ICT vaardigheden automatisch zal leiden tot effectieve integratie van ICT door studenten van de lerarenopleiding basisonderwijs (pabo studenten) in hun toekomstige lespraktijk. In dit onderzoek werkten pabo studenten in het science opleidingsprogramma van PAAET samen in Design Teams (DTs) om curriculum materialen te ontwerpen en vervolgens hun competenties voor het integreren van ICT te ontwikkelen, inclusief hun TPACK.

Dit onderzoek had als doel om pabo studenten met specialisatie science van PAAET voor ICT integratie voor te bereiden. De overkoepelende onderzoeksvraag voor het onderzoek luidt:

"Wat zijn de effecten van het werken in DTs op de kennis, vaardigheden en attitudes van pabo studenten die ICT in hun toekomstige lespraktijken moeten kunnen integreren?"

Vanuit de algemene onderzoeksvraag werden de volgende vier sub-vragen afgeleid: 
1. Wat zijn de percepties, attitudes, en behoeften van pabostudenten in relatie tot ICT integratie, en wat zijn andere voorwaarden voor succesvol gebruik van ICT aan PAAET?

2. Welke veranderingen konden worden waargenomen in Technological Pedagogical Content Knowledge (TPACK), ICT vaardigheden, en attitudes ten opzichte van ICT bij pabo studenten die deelnamen aan de DTs?

3. Welke onderscheidbare effecten hebben Human Support en Blended Support bij pabo studenten op de ontwikkeling van TPACK, en hun attitude en vaardigheden ten opzichte van ICT?

4. Welke TPACK leerresultaten worden door pabo studenten gedemonstreerd na het werken in DTs over ICT integratie en hoe zijn deze TPACK leerresultaten gerelateerd aan de door henzelf gerapporteerde TPACK?

In dit project is een ontwerpgericht onderzoek uitgevoerd, een systematische methode die wordt gekenmerkt door het onderzoeken van complexe problemen in hun natuurlijke omgeving, met als doel het verbeteren van de onderwijspraktijk door middel van iteratieve cycli van analyse, ontwerp, ontwikkeling, en implementatie.

In antwoord op de eerste sub-vraag, 'Wat zijn de percepties, attitudes, en behoeften van pabo studenten in relatie tot ICT integratie, en wat zijn andere voorwaarden voor succesvol gebruik van ICT aan PAAET?' werd een haalbaarheidsonderzoek uitgevoerd om de ontwikkeling van ICT integratie in het opleidingsprogramma voor toekomstige leraren met science specialisatie van informatie te voorzien en te ondersteunen. Uit eerdere onderzoeken (e.g. Albirini, 2006; Baylor \& Ritchie, 2002; Knezek \& Christensen, 2008) zijn verscheidene factoren bekend die het gebruik van computers in de lespraktijk beïnvloeden. Uit deze onderzoeken blijkt dat de attitudes van leraren ten opzichte van computers direct verband houden met het gebruik van computers in de lespraktijk, attitudes zijn van cruciaal belang voor persoonlijk gebruik, en ze bepalen het succes of falen van de introductie van ICT in het klaslokaal. Het vaststellen van de attitudes van de leraren ten opzichte van ICT kan bruikbare inzichten leveren in het proces van ICT integratie, ICT acceptatie, en ICT gebruik bij het lesgeven en leren: verder zou het een goede voorspeller kunnen zijn voor het toekomstig gebruik van ICT door leraren. Daarnaast zijn de ICT vaardigheden van leraren een significante voorspeller van hun attitudes ten opzichte van computers, en onderzoek heeft aangetoond dat, hoewel veel leraren geloven dat computers belangrijke 
hulpmiddelen zijn voor het onderwijs, zij het gebruik van computers in hun onderricht vermijden omdat zij weinig vertrouwen hebben in hun eigen computergebruik, door een gebrek aan kennis en vaardigheden. Daarom zijn de percepties van pabo studenten aan PAAET ten opzichte van het huidige curriculum vastgesteld - vooral in relatie tot ICT, hun attitudes ten opzichte van ICT, hun vaardigheden voor ICT gebruik, en hun behoefte aan ICT training. Uit de resultaten van deze deelstudie bleek dat pabo studenten aan PAAET een positieve attitude ten opzichte van ICT hadden, dat ze beschikten over basale ICT vaardigheden en bewustzijn van ICT en de potentiële rol daarvan in het onderwijs, maar in het onderzoek werd ook gevonden dat ze onzeker waren over hun vermogen om ICT te integreren in hun lesgeven. $\mathrm{Zij}$ zagen zichzelf niet als ICT- integrerende leraren, en hiervoor wezen ze de volgende redenen aan: 1) de ICT-gefocuste cursussen leveren de student niet het vermogen om ICT te integreren in de praktijk; 2) er is sprake van beperkte ICT integratie door het hele programma heen, dus doen de pabo studenten geen ervaring op met authentiek gebruik van ICT bij het lesgeven en leren; en 3) traditionele onderwijsmethoden overheersten het hele opleidingsprogramma aan PAAET. Gebaseerd op deze resultaten, en op een uitgebreid literatuuronderzoek, werden suggesties gedaan voor de ondersteuning van pabo studenten, om de rol van ICT in het onderwijs beter te begrijpen en te ervaren, met de volgende doelen: 1) pabo studenten te helpen begrijpen hoe studentgerichte lespraktijken, ondersteund door ICT, het leren van leerlingen beïnvloeden; 2) pabo studenten concrete voorbeelden te leveren over hoe lesgeven met behulp van ICT er in de praktijk uitziet en verandering in de kennis en attitudes van leraren ten opzichte van ICT te faciliteren; 3) pabo studenten de gelegenheid te bieden om het didactisch gebruik van ICT hulpmiddelen te verkennen en ermee te experimenteren, om pabo studenten te te helpen zich zekerder te voelen over integratie; en 4) werken in een authentieke, collaboratieve leeromgeving als een passende strategie waarmee pabo studenten voorbereid worden op de integratie van ICT in hun toekomstige lespraktijken. De resultaten van deze deelstudie leverden voldoende input voor het tweede onderzoek, waarin veelbelovende aanwijzingen voor de integratie van ICT in het opleidingsprogramma voor science leraren aan PAAET worden ontworpen en onderzocht.

Om de tweede sub-vraag te kunnen beantwoorden, 'Welke veranderingen konden worden waargenomen in Technological Pedagogical Content Knowledge (TPACK), ICT vaardigheden, en attitudes ten opzichte van ICT bij pabo studenten die deelnamen aan de 
DTs?', werd een pilot studie uitgevoerd voor de ontwikkeling van TPACK en Design Teams (DTs). Deze studie had als doel om de ontwikkeling van TPACK door middel van DTs bij pabo studenten te identificeren. Verwacht werd dat door het werken in een DT, de pabo student studentgerichte lespraktijken zou ervaren in een authentieke, actieve en collaboratieve leeromgeving. Het ontwerpen van een ICT-rijke les zou pabo studenten ruimschoots de gelegenheid bieden om ICT hulpmiddelen te leren kennen en ermee te experimenteren, om het didactische gebruik van ICT hulpmiddelen te ervaren, om te begrijpen hoe het lesgeven met ICT er in de praktijk uit zal zien en hoe integratie van ICT in het science curriculum het leren van leerlingen zal beïnvloeden, en om pabo studenten concrete voorbeelden te leveren van effectieve ICT integratie in science onderwijs. De verwachting is dat deze ervaring de ontwikkeling van competenties zal ondersteunen die pabo studenten nodig hebben voor ICT integratie.

In deze tweede deelstudie werden DTs geformeerd om een ICT-rijke oplossing te ontwerpen voor een authentiek onderwijsprobleem horende bij het science curriculum in het basisonderwijs. De DTs werden gecoacht door experts in ICT, vakinhoud, en didactiek. Gedurende het ontwerpproces ontwikkelden de pabo studenten hun ICT vaardigheden en zij begonnen na te denken over ICT als hulpmiddel voor het behalen van leerdoeleinden, meer dan als een doel op zich. Elke pabo student nam actief deel aan het leerproces, werkte samen met verschillende teamleden, leerde door te doen, en experimenteerde met verschillende soorten ICT hulpmiddelen om de didactische problemen op te lossen die ze tegenkwamen. Dit onderzoek leverde pabo studenten aan PAAET de competenties die een ICT-integrerende leraar nodig heeft. De resultaten van het tweede deelonderzoek toonden aan dat de ICT vaardigheden van de pabo studenten significant waren toegenomen nadat zij in DTs hadden gewerkt aan het ontwikkelen en ontwerpen van een oplossing voor een probleem gerelateerd aan de specifieke science vakinhoud, door gebruik te maken van geschikte didactiek en passende ICT hulpmiddelen. De pabo studenten ontwikkelden een positieve attitude ten opzichte van zowel ICT als teamwork, en hun TPACK was toegenomen na het werken in DTs. Dit betekende dat de pabo studenten positieve ervaringen hadden met het gebruik van ICT en dat ze ICT-gerelateerde vaardigheden hadden opgedaan. Daarnaast bleek aan het einde van de interventie, dat de pabo studenten een toename rapporteerden in de bruikbaarheid en het gemak van ICT gebruik, wat suggereerde dat het 
vertrouwen en de competentie voor het gebruik van ICT bij de pabo studenten was toegenomen. Deze bevindingen leverden bewijs dat het werken in een DT het ontwikkelen van TPACK, de kennis die pabo studenten nodig hebben voor ICT integratie in hun lespraktijken, bevorderde.

Een belangrijke bevinding was dat experts die de pabo studenten coachten aangaven dat de face-to-face ondersteuning die ze de DTs leverden tijdens de cursus essentieel was in het leiden van het denken van de studenten richting TPACK; echter, zowel de experts als de pabo studenten erkenden dat face-to-face ondersteuning veel tijd in beslag nam. Daarnaast wensten de pabo studenten meer flexibiliteit voor de leeromgeving die om de ontwikkeling van TPACK te ondersteunen. Naast de behoefte aan flexibiliteit, benadrukten de pabo studenten een behoefte aan een ondersteunend systeem of een omgeving in de Arabische taal. Aangezien studenten aan het PAEET onderwijsopleidingsprogramma gewend zijn aan een docentgerichte benadering bij het leren, zou een omgeving die de ondersteuning door de expert docenten (Human Support) volledig vervangt mogelijk geen effectieve strategie zijn. Voor dit doeleinde werd een gemengde benadering (Blended Support) om de DTs te ondersteunen gekozen om te verkennen in het derde onderzoek.

Uit de bevindingen van het tweede onderzoek, werd een derde sub-vraag geformuleerd, 'Welke onderscheidbare effecten hebben Human Support en Blended Support bij pabo studenten op de ontwikkeling van TPACK, en hun attitude en vaardigheden ten opzichte van ICT?', om te verkennen of het leveren van Blended Support (online ondersteuning geïntegreerd met face-to-face ondersteuning door expert docenten) voor het onderwijs een effectieve en efficiënte alternatieve manier zou kunnen zijn bij het werken in DTs. Dit zou ook de bevindingen van het eerdere onderzoek bevestigen dat het werken in DTs om een ICT-rijke les te ontwikkelen een veelbelovende manier is om de ontwikkeling van TPACK bij pabo studenten aan PAAET te bevorderen. Er werden twee soorten ondersteuning onderscheiden: menselijk en online. De menselijke ondersteuning (Human Support) werd geleverd door de verschillende experts in didactiek, science/wiskunde vakinhoud, en ICT. De Blended Support werd geleverd via een online ondersteuningsportal in Moodle, die handleidingen bevat over hoe verschillende soorten software te gebruiken, voorbeelden van lesplannen waarin ICT geïntegreerd is, een matrix van verschillende ICT toepassingen met passende lesmethoden, en voorbeelden of URL-links over het gebruik van ICT in 
science/wiskunde onderwijs. De portal leverde ook online expertondersteuning door middel van een chat-tool, een werkplaats voor DTs om documenten met elkaar te delen, een discussieforum voor reflectie op de lessen, en een forum voor het reageren op een wekelijkse vraag. Naast het gebruik van de portal, hadden de pabo studenten in de Blended Support conditie de mogelijkheid om experts faceto-face te raadplegen. Het derde onderzoek wees uit dat zowel de Human Support als de Blended Support conditie significante positieve effecten hadden op de attitude, kennis, en vaardigheden van leraren die nodig zijn voor ICT integratie. Dit leidde tot de conclusie dat de Human Support en de Blended Support condities succesvolle alternatieven zijn voor ondersteuning van pabo studenten. Blended Support, echter, liet hogere stijgingen zien in attitudes ten opzichte van ICT, Technological Pedagogical Knowledge (TPK), en Technological Knowldge (TK). Er werden geen verschillen gevonden tussen de twee condities in termen van angst en frustratie ten opzichte van computers, ICT vaardigheden (toets en vragenlijst) en - behalve voor TK en TPK - de andere aspecten van TPACK. Gebaseerd op de bevindingen van dit onderzoek werd geconcludeerd dat het toepassen van de DT benadering gecombineerd met Blended Support bevorderlijk is voor pabo studenten en de docenten die hen begeleiden. De pabo studenten lieten hogere stijgingen zien in attitudes ten opzichte van ICT, TPK en TK in vergelijking met de studenten uit de Human Support conditie; zij deden meer ervaring op met ICT gebruik; en zij ervoeren een studentgerichte benadering. Voor de instructeurs leverde de Blended Support een effectieve en vooral efficiëntere manier van ondersteuning van de pabo studenten.

Om de vierde sub-vraag te beantwoorden, 'Welke TPACK leerresultaten worden door pabo studenten gedemonstreerd na het werken in DTs over ICT integratie en hoe zijn deze TPACK leerresultaten gerelateerd aan de door henzelf gerapporteerde TPACK?', werd een onderzoek uitgevoerd om de TPACK van de pabo studenten door middel van verschillende meetmethoden vast te stellen. Er werd door middel van dit onderzoek onderzocht welke TPACK leerresultaten de pabo studenten demonstreerden na het werken in DTs wat betreft ICT integratie en of de leerresultaten van de pabo studenten gerelateerd waren aan de door henzelf gerapporteerde TPACK. Wat de studenten hadden geleerd over TPACK werd bepaald door middel van een verscheidenheid aan meetmethoden. Om de complexiteit die inherent is aan de gesitueerdheid van het TPACK construct beter bloot te leggen en te begrijpen werd in dit onderzoek door middel van een mixed methods onderzoeksontwerp, de gepercipieerde kennis van ICT integratie 
van pabo studenten (i.e. zelf-rapportages) vergeleken met hun leerresultaten zoals die zichtbaar werden in een lesplan, het ICT product, de TPACK definitie en reflectie, en de ICT vaardigheden toets. De resultaten van deze vierde deelstudie lieten zien dat de pabo studenten die deelnamen aan DTs, in staat waren een ICT-rijk product te ontwikkelen en dit product te integreren in een lesplan, met als doel om een probleem op te lossen gerelateerd aan het onderwijzen van science of wiskunde in het basisonderwijs. De pabo studenten waren in staat om TPACK te definiëren en een situatie te beschrijven waarin ze konden uitdrukken dat ze het TPACK raamwerk konden gebruiken om een onderwerp te doceren gerelateerd aan basisschool science of wiskunde. Ze waren ook in staat om hun product te presenteren aan medestudenten en docenten, en om hun keuze van ICT hulpmiddel, ontwerp-gerelateerde kwesties (e.g. consistentie, contrast, balans, kleurenschema) en didactiek, te verdedigen. Daarbij waren zij in staat om hun argumenten op te bouwen door de verschillende domeinen van TPACK te gebruiken. Het onderzoek toonde ook aan dat de ICT vaardigheden van pabo studenten significant toenamen na het werken in DTs. De bevindingen wezen erop dat pabo studenten in staat waren hun TPACK begrip op verschillende kennisniveaus aan te tonen: declaratief, procedureel, schematisch en strategisch. Gebaseerd op de pre-test van de TPACK vragenlijst, waren de correlaties tussen de verschillende TPACK domeinen klein, medium of niet-bestaand. Met andere woorden, de pabo studenten integreerden de verschillende kennisgebieden niet in hun denken over ICT integratie in het onderwijs. Dit duidt erop dat de zelf-inschatting van TPACK door pabo studenten voordat de interventie van start ging oppervlakkig was of incompleet: echter, de post-test meting van de TPACK vragenlijst toonde significante positieve correlaties tussen TK, PK, CK en hun overlapgebieden. Dit wees erop dat de zelf-inschatting van begrip van TPACK zich bij pabo studenten had ontwikkeld. Een nadere inspectie van de data wees echter uit dat er geen correlaties waren tussen de zelf-gerapporteerde bevindingen en de TPACK leerresultaten. Dit wijst erop dat de perceptie van de pabo studenten over hun eigen TPACK ontwikkeling niet noodzakelijkerwijs op een lijn stond met hun vermogen om de integratie van ICT, didactiek en vakinhoud in de praktijk te demonstreren. Deze onverwachte bevinding stelde de validiteit in twijfel van de manier waarop TPACK was gemeten in de TPACK vragenlijst. De vragenlijst vraagt de pabo studenten om hun TPACK te rapporteren op een algemene en abstracte manier. Om de TPACK van een individu nauwkeuriger te kunnen meten door zelfbeoordeling zou de vragenlijst meer op maat gesneden moeten 
worden op de onderwijspraktijk van de persoon die gevraagd wordt om de vragenlijst in te vullen. Dit houdt in dat het instrument meer specifiek zou moeten zijn over de manier waarop specifieke ICT hulpmiddelen kunnen helpen om de ontwikkeling van misconcepties bij studenten te voorkomen. Dit probleem met de TPACK vragenlijst kan te maken hebben met het feit dat de definitie van het TPACK construct nog relatief vaag is.

Het hoofddoel van dit onderzoek was het voorbereiden van pabo studenten voor ICT integratie in het lesgeven en leren. Om deze redenen toonden de leerresultaten van de pabo studenten hun vermogen om ICT te integreren in het lesgeven en leren beter aan, en daarom dienen zijn als een betere indicator of hun TPACK dan de TPACK vragenlijst.

In het algemeen toonde dit onderzoek aan dat de strategie om TPACK te gebruiken en om in DTs te werken succesvol was in het ontwikkelen van het vermogen tot ICT integratie bij pabo studenten. Bovendien levert deze strategie een theoretische en praktische basis voor ICT integratie in het lerarenopleidingsprogramma, vooral de science lerarenopleiding van PAAET in Koeweit. 


\section{APPENDIX A}

\section{Science Education Program Profile Questionnaire}

Aim: To assess the pre-service science teachers: 1) perception of their current curriculum and the role of ICT within their current program. 2) The needs of the pre-service science teachers at PAAET in relation to ICT in the current program

Source: Developed by the researcher.

Chapters: 2.

استبانه استطلاع رأى الطالبات حول البرنامتج

الهاف من هذا الاستبيان هو استطلاع رأي الطالبات حول برنامج إعداد معلم العلوم للمرحلة الابتدائية في كلية التربية الأساسية التابع للهيئة العامة للتعليم التطبيقي و التدريب. مدة هذا البرنامج هي ثمانية فصول دراسية أي أربعة سنوات دراسية.

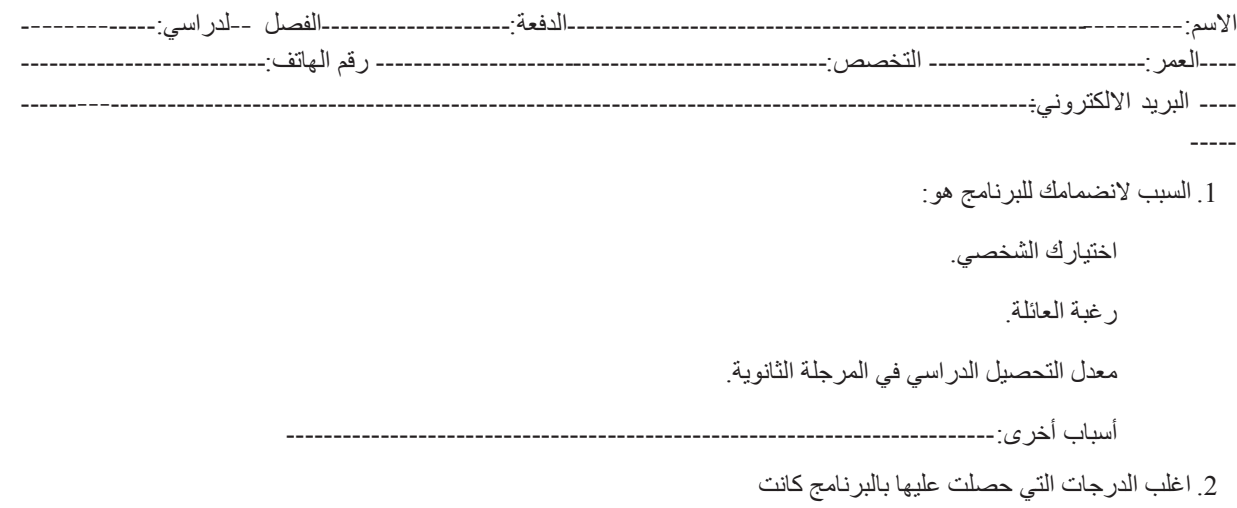

B

$\mathrm{A}-, \mathrm{B}+$

\footnotetext{
D+

$\mathrm{C}, \mathrm{C}-$

$\mathrm{B}-\mathrm{C}+$$$
\text { 3. كيف تقييم مستو اك في اللغة الإنجليزية؟ }
$$$$
\text { متاز }
$$$$
\text { 4. كم عدد الساعات التي تقضيها أسبو عيا خارج الفصل من اجل أنثطة تتعلق ببرنامجك الأكاديمي. مثل الكتابة و القراءة والبحث }
$$$$
\text { العلمي....الخ }
$$

15-11 ساعة/الأسبوع

30-26 ساعة/الأسبوع

6-10 ساعة /الأسبوع

25-21 ساعة/الأسبوع

ج 5 ساعات/الأسبوع

20-16 ساعة/الأسبوع

> 30 ساعة/ الأسبوع
} 
اقرأ الجمل التالية جيدا ثم ضع علامة (ل) في الخانة المناسبة أو التي تعبر عن رأيك:

\begin{tabular}{|c|c|c|c|c|c|c|}
\hline $\begin{array}{l}\text { 高 } \\
\text { 哥 } \\
\text { 等 }\end{array}$ & 商 & $\stackrel{\text { 果; }}{3}$ & s. & $\begin{array}{l}3 \\
3 \\
3 \\
3 \\
3 \\
3\end{array}$ & & J \\
\hline (5) & (4) & (3) & (2) & (1) & الابتبرنائية. أعدني إعدادا جيدا كي اعمل مدرس (علوم/ رياضيات) للمرحلة & .5 \\
\hline (5) & (4) & (3) & (2) & (1) & أفضل دراسة (العلوم/الرياضيات). & .6 \\
\hline & & & & & $\begin{array}{r}\text { الأسلوب الوحيد للتندريس في البرنامج هو الأسلوب المعتد على المدرس } \\
\text { (Teacher centred approach) }\end{array}$ & .7 \\
\hline (5) & (4) & (3) & (2) & (1) & أفضل أن أدرس الطلبة الحقائق و المفاهيم العلمية & .8 \\
\hline (5) & (4) & (3) & (2) & (1) & بالتكنولو من خلال الديثة البرنامج العديد من المهارات العملية ذات الصلة & .9 \\
\hline & & & & & $\begin{array}{r}\text { مارسنا و تعلمنا من خلال البرنامج أساليب التدريس المعتمدة على الطالب } \\
\text { (Student centred approach) }\end{array}$ & .10 \\
\hline (5) & (4) & (3) & (2) & (1) & أحب أن ادخل التكنولوجيا الحديثة في تدريسي بالمستقبل. & .11 \\
\hline (5) & (4) & (3) & (2) & (1) & أستيعابهر. أن دمج التكنولوجيا خلال تدريسي للطلبة سوف يزيد من فهمه و & .12 \\
\hline (5) & (4) & (3) & (2) & (1) & أعتقد أن دمج التكنولو جيا في تدريسي سوف يحفر الطلبة على التعلم & .13 \\
\hline (5) & (4) & (3) & (2) & (1) & التندريس باستخدام التكنولوجيا سيؤُثر على طريقة التدريس. & .14 \\
\hline (5) & (4) & (3) & (2) & (1) & يجب إعادة التنكير في تنظيم محتوى الدرس عند إدخال التكنولوجيا. & .15 \\
\hline (5) & (4) & (3) & (2) & (1) & وجها لوجها تصيم درس باستخدام التكنولوجيا تثبه كثير ا عملية التصميم لدرس & .16 \\
\hline (5) & (4) & (3) & (2) & (1) & تصنميم درس باستخدام التكنولوجيا يتطلب تغيير في طريقة التدريس و & .17 \\
\hline (5) & (4) & (3) & (2) & (1) & استخدام التكنولوجيا في التعليم سوف يحسن العلاقة بين المعلم و الطلاب. & .18 \\
\hline (5) & (4) & (3) & (2) & (1) & اعتقد أن البرنامج أهلني لتوظيف التكنولوجيا في عملي بعد التخرج. & .19 \\
\hline (5) & (4) & (3) & (2) & (1) & 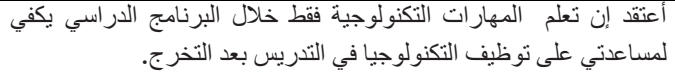 & .20 \\
\hline (5) & (4) & (3) & (2) & (1) & التعليمية الرقمية. زبنية بالمهارات التكنولوجية اللازمة لتصميم و إنتاج الوسائط & .21 \\
\hline (5) & (4) & (3) & (2) & (1) & الرقيةنة زودني بالمبادئ التي يجب إتباعها عند تصميم الوسائط التعليمية & .22 \\
\hline (5) & (4) & (3) & (2) & (1) & 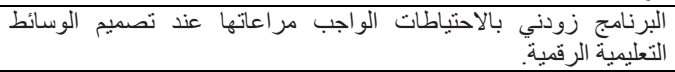 & .23 \\
\hline (5) & (4) & (3) & (2) & (1) & ألعتمدة على بحاجة إلىى المزيد من التندريب و الممارسة لطرق التندريس & .24 \\
\hline (5) & (4) & (3) & (2) & (1) & أعتقد إنني بحاجه للتندريب أكثر على المهارات التكنولوجية. & .25 \\
\hline
\end{tabular}

26. لو أتيحت للك الفرصة لإعادة اختيار مجال التخصص. هل ستختار برنامج إعداد معلم العلوم للمرحلة الابتدائية التابع للهيئة العامة

اللتعليم التطبيقي و التنديب في كلية التربية الأساسية

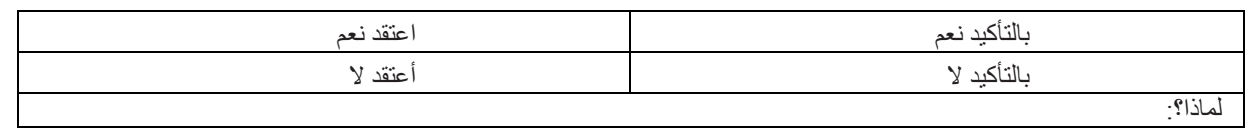

27. ما هي مواطن القوة و الضعف في البرنامج حسب رأيك لكل بند من البنود التالية

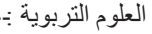




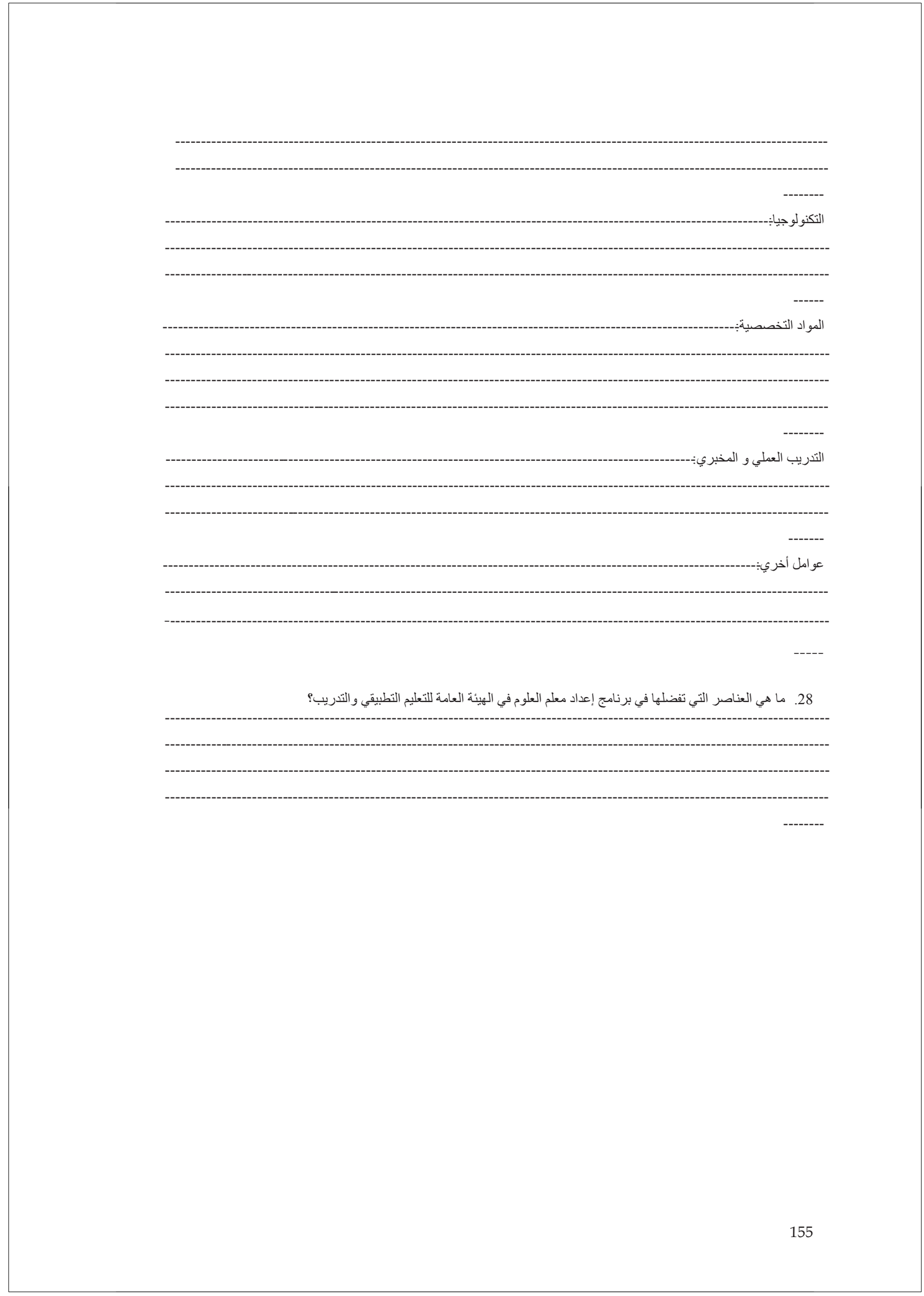




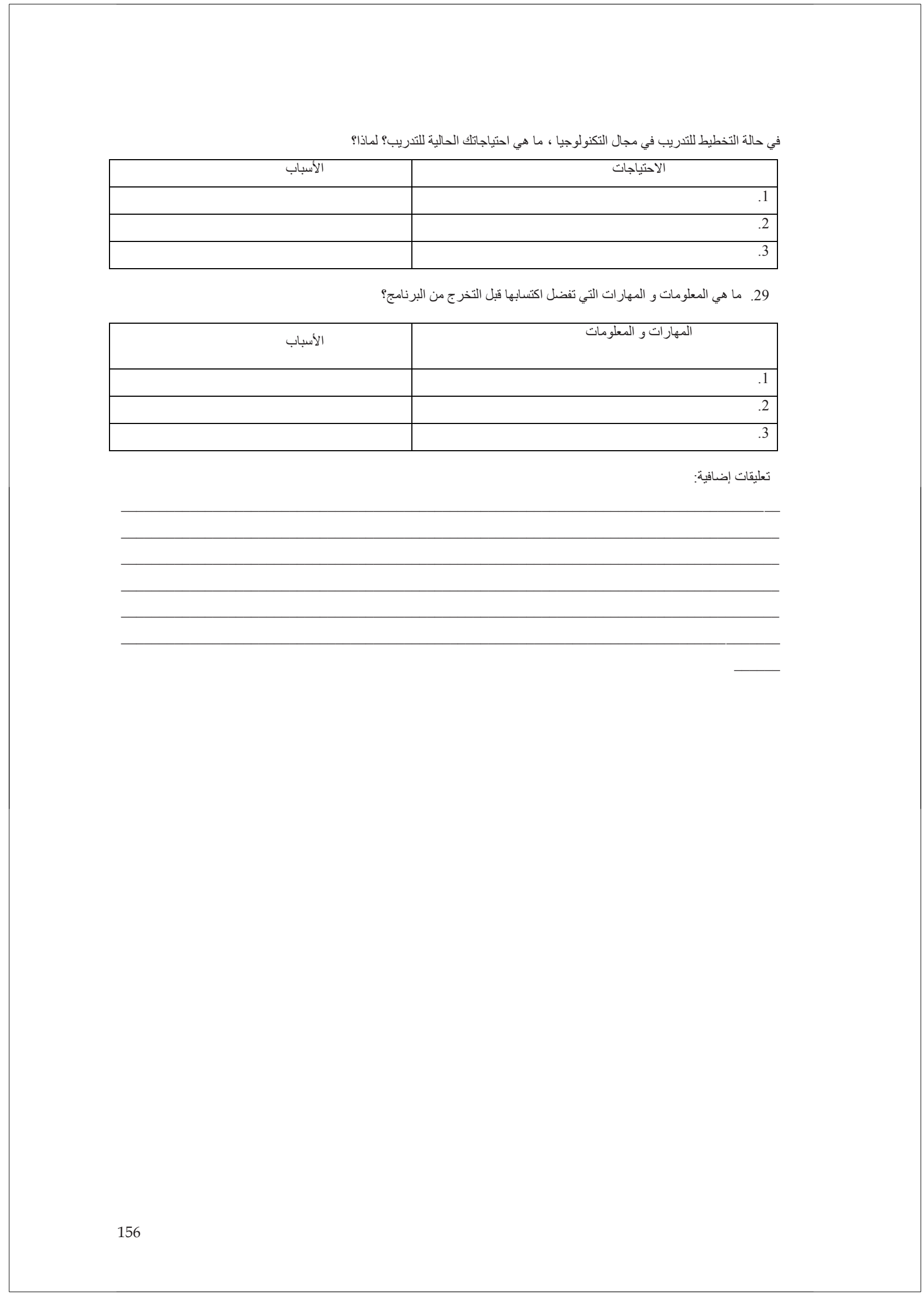




\section{APPENDIX B}

\section{Attitude toward ICT Questionnaire}

Aim: To assess the attitude of the pre-service teachers toward ICT.

Source: adapted from the Teachers' Attitude toward computers questionnaire (TAC) (Christensen \& Knezek, 1996). And six items were added to the TAC about the importance of ICT for learning. Retrieved from http://www.tcet.unt.edu/pubs/studies/survey/caqdesc.htm

Chapters: $2,3,4,5$.

\section{Attitude toward ICT Questionnaire}

1. Do you use a computer at home?

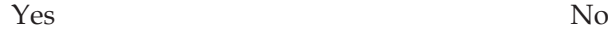

No

2. Do you have World Wide Web (www) access at home?

Yes

3. Do you have an access to a computer at your collage or department? Yes

No

4. Do you have internet access at your department or college? Yes No

Read each statement and then circle the number which best shows how you feel. (SD = Strongly Disagree $\mathrm{D}=$ Disagree $\mathrm{U}=$ Undecided A = Agree SA = Strongly Agree $)$

\begin{tabular}{llccccc} 
& SD & D & U & A & SA \\
\hline $5 . \quad$ I enjoy doing things on a computer & $(1)$ & $(2)$ & $(3)$ & $(4)$ & $(5)$
\end{tabular}

6. I am tired of using a computer

7. I will be able to get a good job if I learn how to use a computer.

8. I concentrate on a computer when I use one

9. I enjoy computer games very much

10. I would work harder if I could use computers more often

11. I know that computers give me opportunities to learn many new things.

12. I can learn many things when I use a computer 
13. I enjoy lessons on the computer

14. I believe that the more often teachers use computers, the more I will enjoy school

15. I believe that it is very important for me to learn how to use a computer.

16. I feel comfortable working with a computer

17. I get a sinking feeling when I think of trying to use a computer.

18. I think that it takes a long time to finish when I use a computer.

19. Working with a computer makes me nervous

20. Using a computer is very frustrating

21. I will do as little work with computers as possible

22. Computers are difficult to use

23. Computers do not scare me at all

24. I can learn more from books than from a computer

25. Computers are valuable tools that can be used to improve the quality of education. *

26. Teachers should know how to use computers in their classrooms. *

27. If there is a computer in my future classroom, It would help me to be a better teacher. *

28. I would like to have a computer for use in my classroom. *

29. I enjoy using new technology for instruction. *

30. I believe textbooks will be replaced by electronic media. *

31. I believe that the roles of schools will be dramatically changed because of the internet. *

32. I need more technical support to keep the computers working. *

\begin{tabular}{|c|c|c|c|}
\hline (1) & (2) & (3) & (4) \\
\hline (1) & (2) & (3) & (4) \\
\hline (1) & (2) & (3) & (4) \\
\hline (1) & (2) & (3) & (4) \\
\hline (1) & (2) & (3) & (4) \\
\hline (1) & (2) & (3) & (4) \\
\hline (1) & (2) & (3) & (4) \\
\hline (1) & (2) & (3) & (4) \\
\hline (1) & (2) & (3) & (4) \\
\hline (1) & (2) & (3) & (4) \\
\hline (1) & (2) & (3) & (4) \\
\hline (1) & (2) & (3) & (4) \\
\hline (1) & (2) & (3) & (4) \\
\hline (1) & (2) & (3) & (4) \\
\hline (1) & (2) & (3) & (4) \\
\hline (1) & (2) & (3) & (4) \\
\hline (1) & (2) & (3) & (4) \\
\hline (1) & (2) & (3) & (4) \\
\hline (1) & (2) & (3) & (4) \\
\hline (1) & (2) & (3) & (4) \\
\hline
\end{tabular}

* adapted and modified by the researcher 


\section{APPENDIX C}

\section{Attitude toward Teamwork Questionnaire}

Aim: To assess the attitude of the pre-service teachers toward teamwork and design teams. Source: developed by researcher.

Chapters: 3.

اتجاهات الطالبات حول العمل الجماعى و فرق العمل:

هذه الاستبانة تقييم اتجاهات الطالبات حول فرق العمل و العمل الجماعي. اقرأ كل عبارة ثم ضع دائرة حول أفضل رقم يوضح شعورك.

\begin{tabular}{|c|c|c|c|c|c|}
\hline 商 & 高 & $\stackrel{4}{3}$ & 3 & 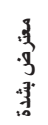 & \\
\hline (5) & (4) & (3) & (2) & (1) & 1. أستمتع بالعمل في مجموعات أو فرق العمل \\
\hline (5) & (4) & (3) & (2) & (1) & 2. غالبا ما أعمل في مجمو عات \\
\hline (5) & (4) & (3) & (2) & (1) & 3. اتخاذ القرار بشكل جماعي أفضل للمجتمع و المؤسسات \\
\hline (5) & (4) & (3) & (2) & (1) & 4. أفضل العمل منفردا على العمل كفريق \\
\hline (5) & (4) & (3) & (2) & (1) & 5. أرتاح عند القيام بالأدوار القيادية \\
\hline (5) & (4) & (3) & (2) & (1) & 6. أعمل بنشاطو فاعلية من خلال فرق العمل أو العمل الجماعي \\
\hline (5) & (4) & (3) & (2) & (1) & 7. عطلوبما تضطي فقطي الظروف للعمل الجماعي أو الاشتر اك بفرق العمل أقوم بما هو. \\
\hline (5) & (4) & (3) & (2) & (1) & 8. لا أفضل أن يتم تقيمي بناء على العمل كفريق أو العمل الجماعي. \\
\hline (5) & (4) & (3) & (2) & (1) & 9. ل لدي القدرة على الدكم على الأثخاص بشكل جيد \\
\hline (5) & (4) & (3) & (2) & (1) & 10. استطيع قراءة و فهم الآخرين بشكل جيد. \\
\hline (5) & (4) & (3) & (2) & (1) & 11. أنعر إن لاي أثنياء مهمة أقولها عند العمل من خلال الفريق. \\
\hline (5) & (4) & (3) & (2) & (1) & 12. أفضل تثكيل مجمو عات من الطلبة للعمل كفرق عمل من اجل أداء مهمة محدده في \\
\hline
\end{tabular}




\section{APPENDIX D \\ ICT Skills Questionnaire}

Aim: To assess the pre-service teachers' level of ICT skills.

Source: created by combining two existing instruments (the national survey on information technology in teachers education by the Milken Exchange on Educational technology (1999) and the Technology Proficiency Self-Assessment (TPSA) by Ropp (1999). Some items were added by the researcher, to assess additional ICT skills such as video conferencing, multimedia production, and simulation

Chapters: $2,3,4$.

\section{ICT Skill Questionnaire}

Did you take 'introduction to computer' (course 111) provided by educational technology department? Yes No

Instructions: Select one level of agreement for each statement to indicate how you feel. $\underline{\mathrm{SD}}=$ Strongly Disagree, $\mathrm{D}=$ Disagree, $\mathrm{U}=$ Undecided, $\mathrm{A}=$ Agree, $\mathrm{SA}=$ Strongly Agree

The kind of things I do a lot on a computer at school are:

1. Subject-specific software (science, math, reading, etc.).

SD

D $\quad$ U A SA

2. Word processing activities.

3. Spreadsheet activities.

4. Database activities.

5. Creating presentations (PowerPoint etc.)

6. Looking up information on CD-ROMs.

7. Looking for information on the World Wide Web (Internet).

8. Visiting virtual labs to conduct some experiments or investigation. *

9. Joining video conferences to get/share information about specific content with experts. *

10. Exploring environment or solving a problem by using simulation programs. *

I feel confident that I could:

\begin{tabular}{|c|c|c|c|c|}
\hline (1) & (2) & (3) & (4) & (5) \\
\hline (1) & (2) & (3) & (4) & (5) \\
\hline (1) & (2) & (3) & (4) & (5) \\
\hline (1) & (2) & (3) & (4) & (5) \\
\hline (1) & (2) & (3) & (4) & (5) \\
\hline (1) & (2) & (3) & (4) & (5) \\
\hline (1) & (2) & (3) & (4) & (5) \\
\hline (1) & (2) & (3) & (4) & (5) \\
\hline (1) & (2) & (3) & (4) & (5) \\
\hline (1) & (2) & (3) & (4) & (5) \\
\hline (1) & (2) & (3) & (4) & (5) \\
\hline
\end{tabular}


12. Create an "address book" to send e-mail to several people at once.

\begin{tabular}{|c|c|c|c|}
\hline (1) & (2) & (3) & (4) \\
\hline (1) & (2) & (3) & (4) \\
\hline (1) & (2) & (3) & (4) \\
\hline (1) & (2) & (3) & (4) \\
\hline (1) & (2) & (3) & (4) \\
\hline (1) & (2) & (3) & (4) \\
\hline (1) & (2) & (3) & (4) \\
\hline (1) & (2) & (3) & (4) \\
\hline (1) & (2) & (3) & (4) \\
\hline (1) & (2) & (3) & (4) \\
\hline (1) & (2) & (3) & (4) \\
\hline (1) & (2) & (3) & (4) \\
\hline (1) & (2) & (3) & (4) \\
\hline (1) & (2) & (3) & (4) \\
\hline & (2) & (3) & (4) \\
\hline
\end{tabular}

13. Send a document as an attachment to an e-mail message.

14. Use an Internet search engine (e.g., Alta Vista, Google) to find Web pages related to my subject matter interests.

15. Search for and find the PAAET Web site.

16. Create my own World Wide Web home page.

17. Keep track of Web sites I have visited so that I can return to them later. (An example is using bookmarks.)

18. Create a newsletter with graphics and text in 3 columns.

19. Use the computer to create a slideshow presentation.

20. Edit video clips by video editing software.

21. Record and edit sound by sound editing software.

22. Create a database of information about important authors in a subject.

23. Create and edit graphics for multimedia presentations or for web pages *.

24. Create 3D model for a specific structure or part. *

25. Simulate phenomena or process by using computer software *

26. Animate object to explain a phenomena or process. *

* adapted and modified by the researcher

Thank you for your time. 


\section{APPENDIX E \\ ICT Skill Test}

Aim: Performance attainment test, to assess the pre-service teachers' level of ICT skills.

Source: developed by the researcher

Chapters: $2,3,4,5$.

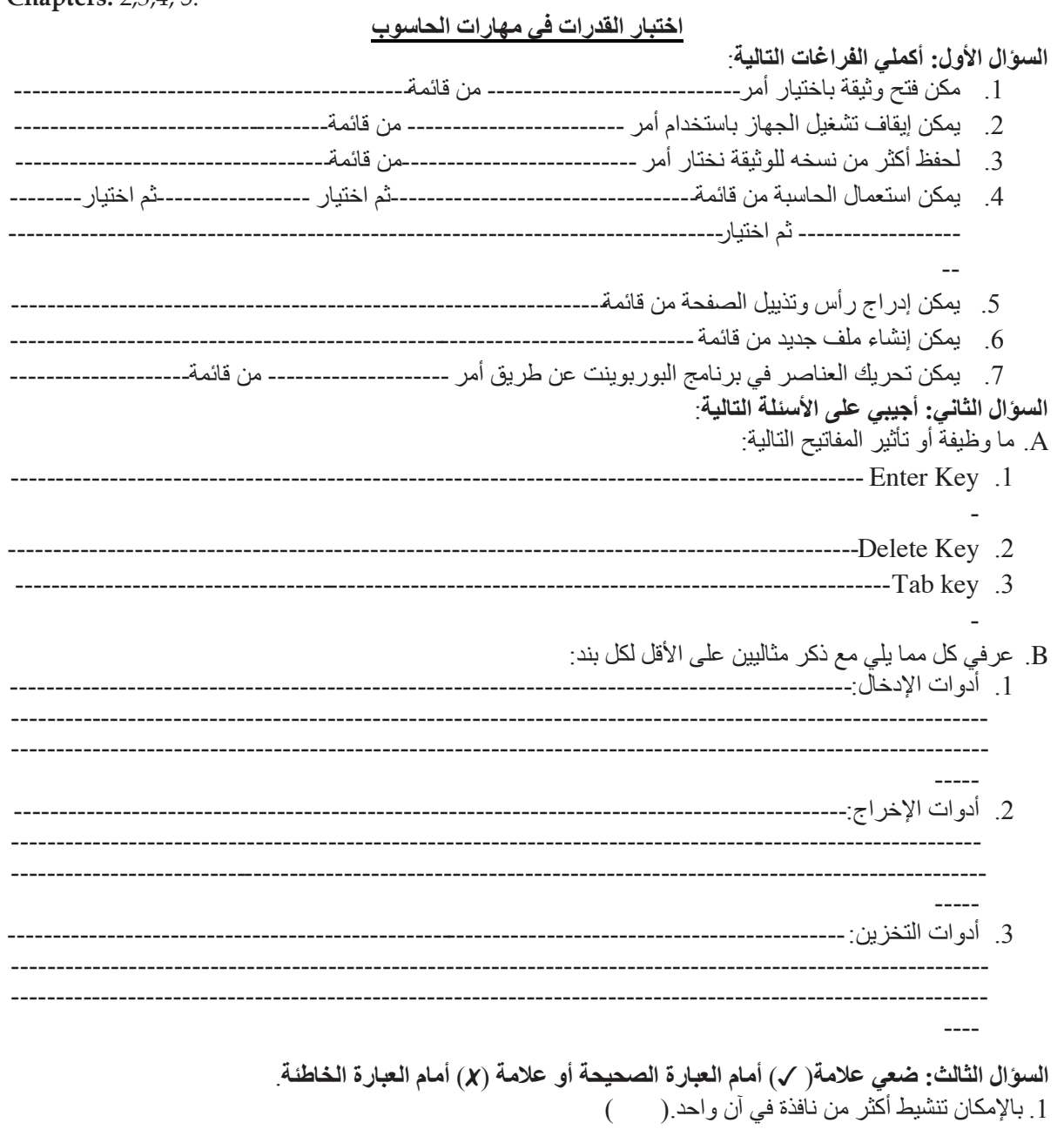




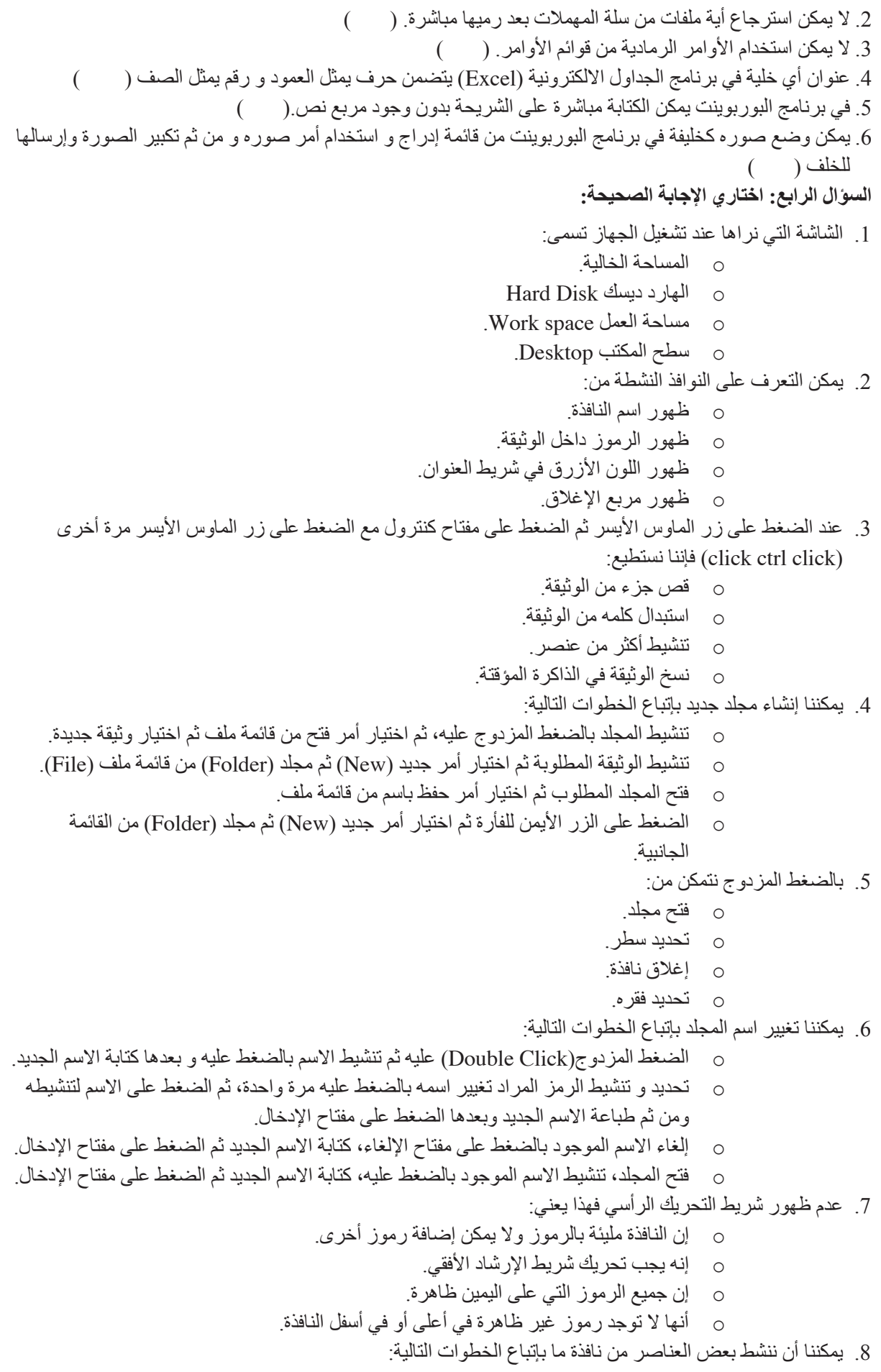




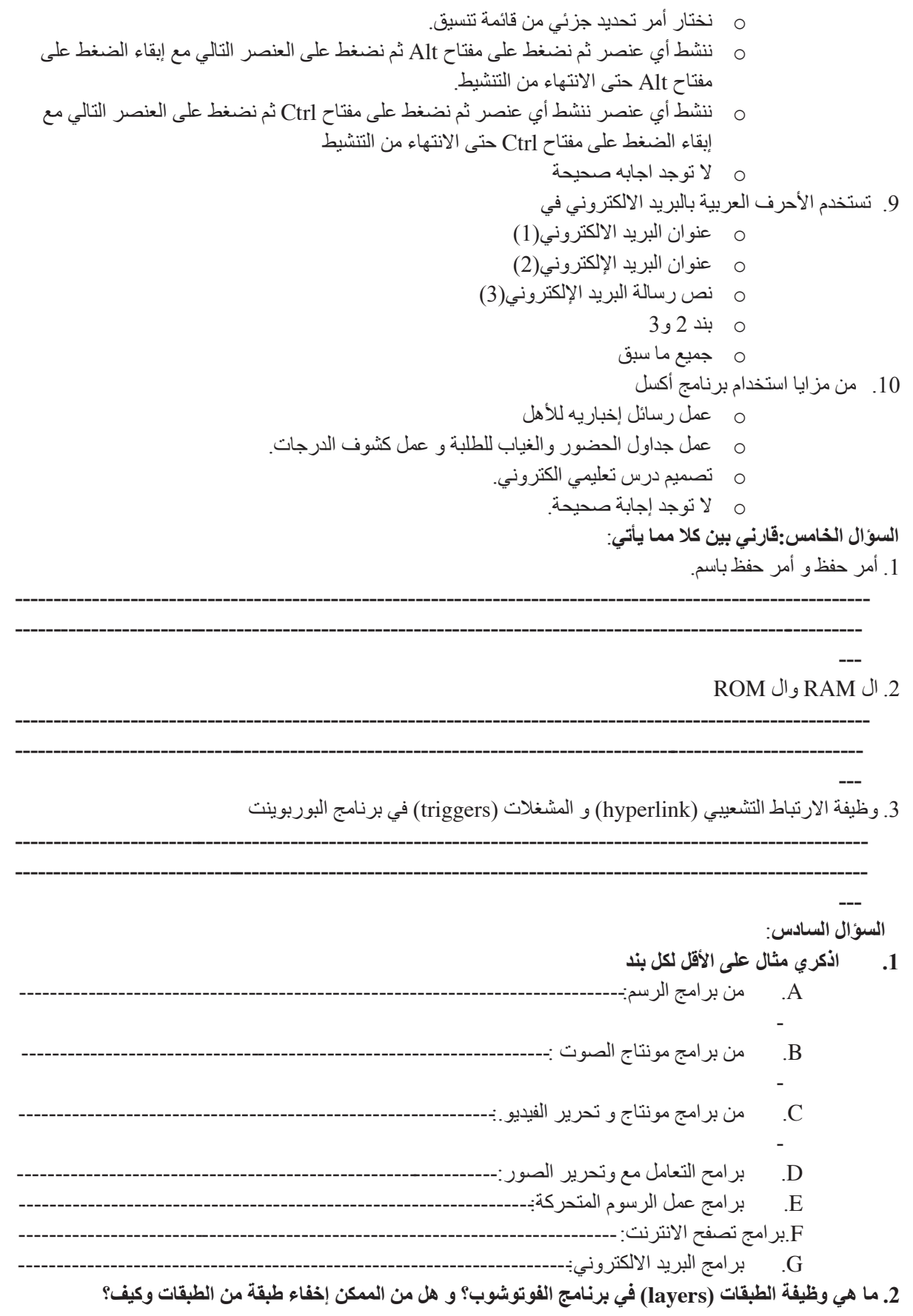




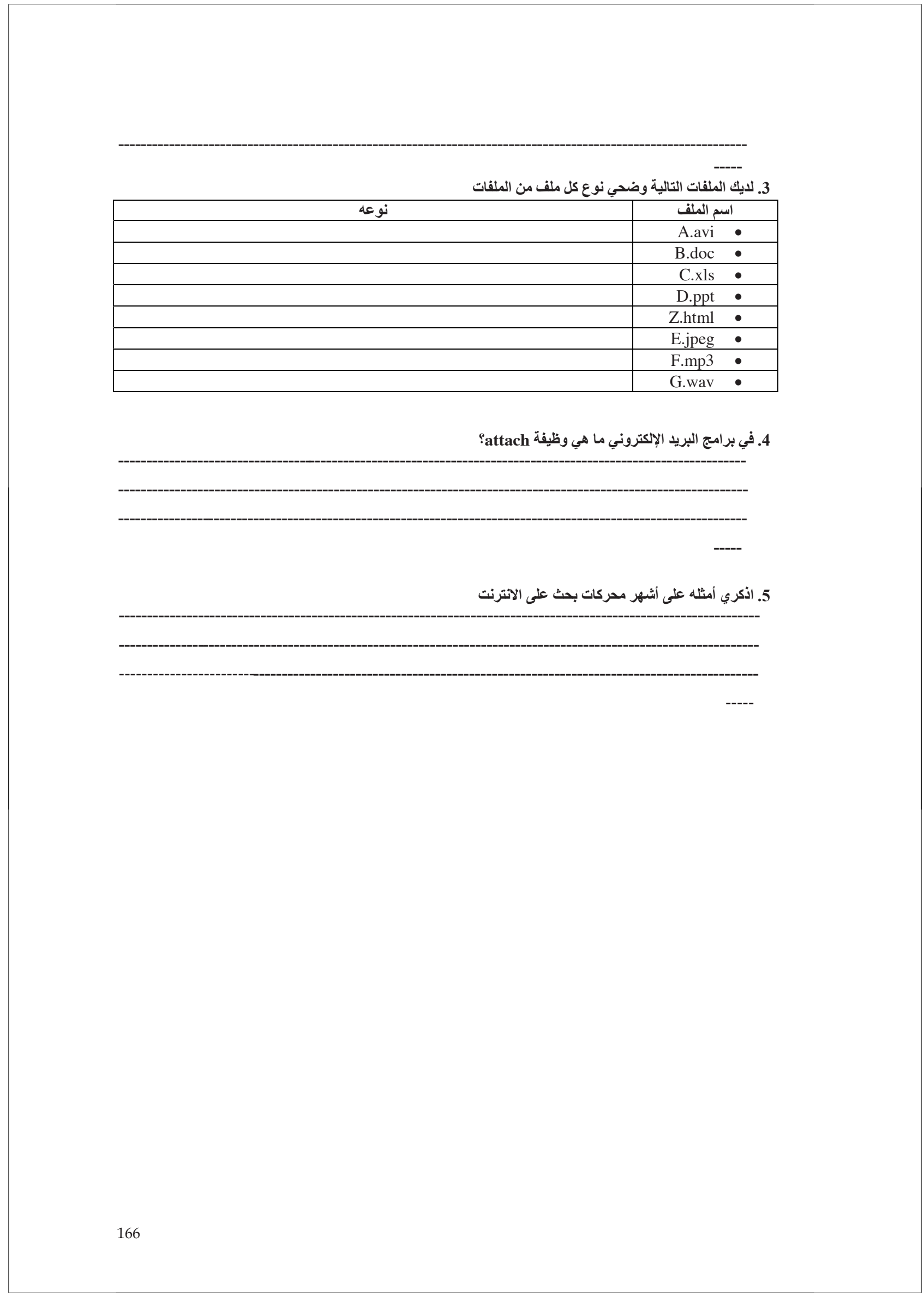


6. لديك صندوق أدوات برنامج الفوتوشوب اشرحي دور كل أداة من الأدوات التالية:

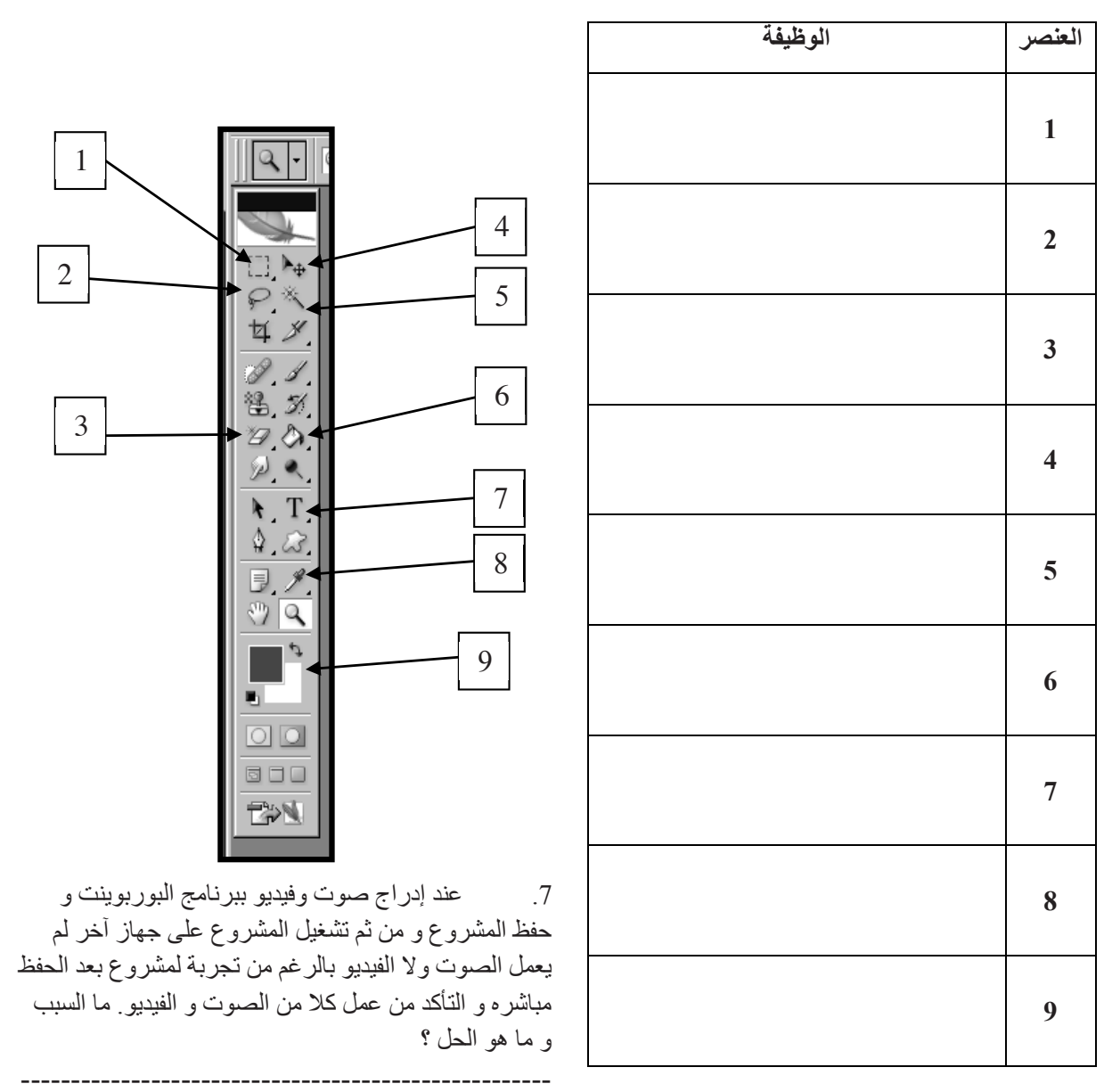

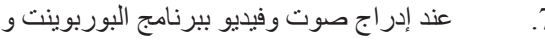

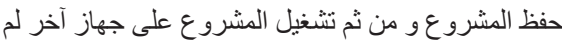

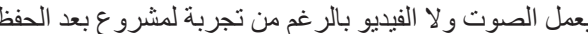

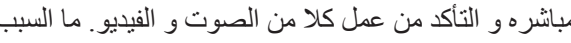

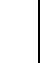

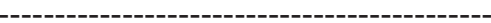




\section{APPENDIX F TPACK Survey}

Aim: To assess the development of TPACK in the pre-service teachers

Source: Schmidt, D., Baran, E., Thompson, A., Koehler, M. J., Shin, T., \& Mishra, P. (2009). Technological Pedagogical Content Knowledge (TPACK): The Development and Validation of an Assessment Instrument for Pre-service Teachers. Paper presented at the Annual Meeting of the American Educational Research Association, San Diego, California.

Chapters: $3,4,5$.

Instructions: Select one level of agreement for each statement to indicate how you feel. $\mathrm{SD}=$ Strongly Disagree, $\mathrm{D}=$ Disagree, $\mathrm{U}=$ Undecided, $\mathrm{A}=$ Agree, SA = Strongly Agree

\begin{tabular}{|c|c|c|c|c|c|}
\hline & SD & $\mathbf{D}$ & $\mathrm{U}$ & $\mathbf{A}$ & SA \\
\hline 1.I know how to solve my own technical problems & (1) & (2) & (3) & (4) & (5) \\
\hline 2.I can learn technology easily. & (1) & (2) & (3) & (4) & (5) \\
\hline 3. I keep up with the important new technologies. & (1) & (2) & (3) & (4) & (5) \\
\hline 4.I frequently play around the technology & (1) & (2) & (3) & (4) & (5) \\
\hline 5.I know a lot of different technologies. & (1) & (2) & (3) & (4) & (5) \\
\hline 6.I have technical skills I need to use technology & (1) & (2) & (3) & (4) & (5) \\
\hline $\begin{array}{l}\text { 7.I have had sufficient opportunities to work with } \\
\text { different technologies }\end{array}$ & (1) & (2) & (3) & (4) & (5) \\
\hline 8.I have sufficient knowledge about (science/math) & (1) & (2) & (3) & (4) & (5) \\
\hline 9.I can use a scientific/mathematical way of thinking & (1) & (2) & (3) & (4) & (5) \\
\hline $\begin{array}{l}\text { 10.I have various ways \& strategies of developing my } \\
\text { understanding of (science/math) }\end{array}$ & (1) & (2) & (3) & (4) & (5) \\
\hline $\begin{array}{l}\text { 11.I know how to assess student performance in a } \\
\text { classroom. }\end{array}$ & (1) & (2) & (3) & (4) & (5) \\
\hline $\begin{array}{l}\text { 12.I can adapt my teaching based-upon what students } \\
\text { currently understand or do not understand. }\end{array}$ & (1) & (2) & (3) & (4) & (5) \\
\hline 13. I can adapt my teaching style to different learners. & (1) & (2) & (3) & (4) & (5) \\
\hline 14. I can assess student learning in multiple ways. & (1) & (2) & (3) & (4) & (5) \\
\hline $\begin{array}{l}\text { 15. I can use a wide range of teaching approaches in a } \\
\text { classroom setting (collaborative learning, direct }\end{array}$ & (1) & (2) & (3) & (4) & (5) \\
\hline
\end{tabular}


instruction, inquiry learning, problem/project based learning etc.)

16. I am familiar with common student understandings \& misconceptions.

17.I know how to organize \& maintain classroom management.

18.I know how to select effective teaching approaches to guide student thinking \& learning in science or math

19.I know about the technologies that I can use for understanding \& doing science or math.

20.I can choose technologies that enhance the teaching approaches for a lesson.

21.I can choose technologies that enhance students learning for a lesson.

22.my teacher education program has caused me to think more deeply about how technology could influence the teaching approaches I use in my classroom

23. I am thinking critically about how to use technology in my classroom.

24. I can adapt the use of the technologies that I am learning about to different teaching activities.

25.I can teach lessons that appropriately combine science/math, technologies and teaching approaches.

26.I select technologies to use in my classroom that enhance what I teach, how I teach and what students learn.

27. I can use strategies that combine content, technologies \& teaching approaches that I learned about in my coursework in my classroom.

28.I can provide leadership in helping others to coordinate the use of content, technologies, and teaching approaches at my school \&/or district.

29.I can choose technologies that enhance the content for a lesson.

\begin{tabular}{|c|c|c|c|c|}
\hline (1) & (2) & (3) & (4) & (5) \\
\hline (1) & (2) & (3) & (4) & (5) \\
\hline (1) & (2) & (3) & (4) & (5) \\
\hline (1) & (2) & (3) & (4) & (5) \\
\hline (1) & (2) & (3) & (4) & (5) \\
\hline (1) & (2) & (3) & (4) & (5) \\
\hline (1) & (2) & (3) & (4) & (5) \\
\hline (1) & (2) & (3) & (4) & (5) \\
\hline (1) & (2) & (3) & (4) & (5) \\
\hline (1) & (2) & (3) & (4) & (5) \\
\hline (1) & (2) & (3) & (4) & (5) \\
\hline (1) & (2) & (3) & (4) & (5) \\
\hline (1) & (2) & (3) & (4) & (5) \\
\hline (1) & (2) & (3) & (4) & (5) \\
\hline
\end{tabular}




\section{APPENDIX G}

\section{Presentation Rubric}

Aim: To assess the ability of pre-service teachers to present the idea behind the final product for experts and peers.

Source: developed by researcher.

Chapters: 5 .

\begin{tabular}{|l|c|c|c|}
\hline Criteria & & Points & Marks \\
\hline & $\begin{array}{c}\text { Content } \\
\text { (CK) }\end{array}$ & 1 & \\
\cline { 2 - 4 } $\begin{array}{l}\text { Accuracy of given } \\
\text { information in relation to: }\end{array}$ & $\begin{array}{c}\text { ICT } \\
\text { (TK) }\end{array}$ & 1 & \\
\cline { 2 - 4 } & $\begin{array}{c}\text { Pedagogy } \\
\text { (PK) }\end{array}$ & 1 & \\
\hline \multicolumn{2}{|l|}{ Self-confidence } & 1 & \\
\hline $\begin{array}{l}\text { Eye contact and directing the talk to the } \\
\text { audience. }\end{array}$ & 1 & \\
\hline Verbal technique (i.e. voice tone and clarity) & 1 & \\
\hline \multicolumn{2}{|l|}{ Total: } & 6 & \\
\hline
\end{tabular}




\section{APPENDIX $\mathbf{H}$ \\ TPACK Definition Rubric}

Aim: To assess the pre-service teacher understanding of the TPACK framework.

Source: developed by researcher

Chapters: $3,4,5$.

\begin{tabular}{|l|l|l|l|l|}
\hline Points & $\mathbf{3}$ & $\mathbf{2}$ & $\mathbf{1}$ & $\mathbf{0}$ \\
\hline $\begin{array}{l}\text { Definition Of } \\
\text { TPACK }\end{array}$ & & & & \\
\hline & $\begin{array}{l}\text { PK, TK, CK } \\
\text { interact and } \\
\text { intertwined } \\
\text { (PCK,TPK, TCK } \\
\text { E TPACK) } \\
\text { together in state } \\
\text { of equilibrium } \\
\text { within the } \\
\text { context }\end{array}$ & $\begin{array}{l}\text { PK, TK, CK } \\
\text { interact and } \\
\text { intertwined }\end{array}$ & $\begin{array}{l}\text { PK, TK, CK } \\
\text { interact with } \\
\text { each other }\end{array}$ & $\begin{array}{l}\text { PK, TK and CK } \\
\text { (or no } \\
\text { explanation at } \\
\text { all) }\end{array}$ \\
\hline
\end{tabular}




\section{APPENDIX I}

\section{TPACK Reflection Rubric}

Aim: To assess the pre-service teachers' understanding of TPACK and whether they can relate TPACK to their own teaching experience during their in-school training.

Source: developed by researcher.

Chapters: $3,4,5$.

\begin{tabular}{|c|c|c|c|c|}
\hline \multirow{2}{*}{ TPACK Example } & \multicolumn{4}{|c|}{ ICT (TK) } \\
\hline & 3 & 2 & 1 & 0 \\
\hline $\begin{array}{l}\text { - Topic/objective } \\
\text { (CK) }\end{array}$ & $\begin{array}{l}\text { ICT tools } \\
\text { selected are } \\
\text { strongly aligned } \\
\text { with the Content } \\
\text { and all the } \\
\text { lesson objectives }\end{array}$ & \begin{tabular}{|l} 
ICT tools \\
selected are \\
aligned with \\
the content and \\
at least one \\
objectives of \\
the lesson \\
\end{tabular} & $\begin{array}{l}\text { ICT tools } \\
\text { selected are } \\
\text { partially aligned } \\
\text { with the content } \\
\text { and at least one } \\
\text { objectives of the } \\
\text { lesson }\end{array}$ & $\begin{array}{l}\text { ICT tools } \\
\text { selected are no } \\
\text { aligned with the } \\
\text { content and the } \\
\text { lesson objectives }\end{array}$ \\
\hline $\begin{array}{l}\text { - Target } \\
\text { (Context) }\end{array}$ & $\begin{array}{l}\text { ICT tools } \\
\text { selected are } \\
\text { suitable for the } \\
\text { target group and } \\
\text { context }\end{array}$ & \begin{tabular}{|l|} 
ICT tools \\
selected need \\
an effort to \\
support target \\
student to work
\end{tabular} & $\begin{array}{l}\text { ICT tools } \\
\text { selected need } \\
\text { extra support } \\
\text { from both } \\
\text { parents and } \\
\text { instructors for } \\
\text { target group to } \\
\text { work on }\end{array}$ & $\begin{array}{l}\text { ICT selected } \\
\text { tools are not } \\
\text { suitable for the } \\
\text { target group }\end{array}$ \\
\hline $\begin{array}{l}\text { - Teaching } \\
\text { strategy } \\
\text { (PK) }\end{array}$ & $\begin{array}{l}\text { ICT used } \\
\text { optimally } \\
\text { supports } \\
\text { teaching strategy }\end{array}$ & $\begin{array}{l}\text { ICT used } \\
\text { supports } \\
\text { teaching } \\
\text { strategy } \\
\end{array}$ & $\begin{array}{l}\text { ICT used } \\
\text { minimally } \\
\text { supports } \\
\text { teaching strategy }\end{array}$ & $\begin{array}{l}\text { ICT used does } \\
\text { not supports } \\
\text { teaching strategy }\end{array}$ \\
\hline $\begin{array}{l}\text { - Overall fit } \\
\text { (CK, PK \& } \\
\text { Context) }\end{array}$ & $\begin{array}{l}\text { ICT tool, CK, } \\
\text { Context and PK } \\
\text { fit strongly } \\
\text { together }\end{array}$ & $\begin{array}{l}\text { ICT tool, CK, } \\
\text { Context and PK } \\
\text { fit together }\end{array}$ & $\begin{array}{l}\text { ICT tool, CK, } \\
\text { Context and PK } \\
\text { somewhat fit } \\
\text { together }\end{array}$ & $\begin{array}{l}\text { ICT tool, CK, } \\
\text { Context and PK } \\
\text { do not fit } \\
\text { together }\end{array}$ \\
\hline $\begin{array}{l}\text { - Student role } \\
\text { with ICT }\end{array}$ & $\begin{array}{l}\text { Yes } \\
\text { - Highly active }\end{array}$ & - Active & - Partially & $\begin{array}{l}\text { No } \\
\text { - Not active }\end{array}$ \\
\hline
\end{tabular}




\section{APPENDIX J \\ TPACK Lesson Plan Rubric}

Aim: To assess the ICT integration in the lesson plans of the Design Teams.

Source: Harris, J., Grandgenett, N. \& Hofer, M. (2010). Testing a TPACK-Based Technology Integration Assessment Rubric. In D. Gibson \& B. Dodge (Eds.), Proceedings of Society for Information Technology \& Teacher Education International Conference 2010 (pp. 3833-3840). Chesapeake, VA: AACE

Chapters: 5 .

\begin{tabular}{|c|c|c|c|c|}
\hline Criteria & 4 & 3 & 2 & 1 \\
\hline $\begin{array}{l}\text { Curriculum Goals \& } \\
\text { Technologies } \\
\text { (Curriculum-based } \\
\text { technology use) }\end{array}$ & \begin{tabular}{|l} 
Technologies \\
selected for use in \\
the instructional plan \\
are strongly aligned \\
with one or more \\
curriculum goals.
\end{tabular} & $\begin{array}{l}\text { Technologies } \\
\text { selected for use in the } \\
\text { instructional plan are } \\
\text { aligned with one or } \\
\text { more curriculum } \\
\text { goals. }\end{array}$ & $\begin{array}{l}\text { Technologies } \\
\text { selected for use in } \\
\text { the instructional plan } \\
\text { are partially aligned } \\
\text { with one or more } \\
\text { curriculum goals. }\end{array}$ & $\begin{array}{l}\text { Technologies } \\
\text { selected for use in } \\
\text { the instructional } \\
\text { plan are not aligned } \\
\text { with any curriculum } \\
\text { goals. }\end{array}$ \\
\hline $\begin{array}{l}\text { Instructional } \\
\text { Strategies \& } \\
\text { Technologies } \\
\text { (Using technology in } \\
\text { teaching/ } \\
\text { learning) }\end{array}$ & $\begin{array}{l}\text { Technology use } \\
\text { optimally supports } \\
\text { instructional } \\
\text { strategies. }\end{array}$ & $\begin{array}{l}\text { Technology use } \\
\text { supports instructional } \\
\text { strategies. }\end{array}$ & $\begin{array}{l}\text { Technology use } \\
\text { minimally supports } \\
\text { instructional } \\
\text { strategies. }\end{array}$ & $\begin{array}{l}\text { Technology use } \\
\text { does not support } \\
\text { instructional } \\
\text { strategies. }\end{array}$ \\
\hline $\begin{array}{l}\text { Technology } \\
\text { Selection(s) } \\
\text { (Compatibility with } \\
\text { curriculum goals \& } \\
\text { instructional } \\
\text { strategies) }\end{array}$ & $\begin{array}{l}\text { Technology } \\
\text { selection(s) are } \\
\text { exemplary, given } \\
\text { curriculum goal(s) } \\
\text { and instructional } \\
\text { strategies. }\end{array}$ & $\begin{array}{l}\text { Technology } \\
\text { selection(s) are } \\
\text { appropriate, but not } \\
\text { exemplary, given } \\
\text { curriculum goal(s) } \\
\text { and instructional } \\
\text { strategies. }\end{array}$ & $\begin{array}{l}\text { Technology } \\
\text { selection(s) are } \\
\text { marginally } \\
\text { appropriate, given } \\
\text { curriculum goal(s) } \\
\text { and instructional } \\
\text { strategies. }\end{array}$ & $\begin{array}{l}\text { Technology } \\
\text { selection(s) are } \\
\text { inappropriate, given } \\
\text { curriculum goal(s) } \\
\text { and instructional } \\
\text { strategies. }\end{array}$ \\
\hline $\begin{array}{l}\text { "Fit" } \\
\text { (Content, pedagogy } \\
\text { and technology } \\
\text { together) }\end{array}$ & $\begin{array}{l}\text { Content, } \\
\text { instructional } \\
\text { strategies and } \\
\text { technology fit } \\
\text { together strongly } \\
\text { within the } \\
\text { instructional plan. }\end{array}$ & $\begin{array}{l}\text { Content, instructional } \\
\text { strategies and } \\
\text { technology fit } \\
\text { together within the } \\
\text { instructional plan. }\end{array}$ & $\begin{array}{l}\text { Content, } \\
\text { instructional } \\
\text { strategies and } \\
\text { technology fit } \\
\text { together somewhat } \\
\text { within the } \\
\text { instructional plan. }\end{array}$ & $\begin{array}{l}\text { Content, } \\
\text { instructional } \\
\text { strategies and } \\
\text { technology do not fit } \\
\text { together within the } \\
\text { instructional plan. }\end{array}$ \\
\hline
\end{tabular}




\section{APPENDIX K \\ TPACK Product Rubric}

Aim: To evaluate the Design Teams' product in relation to technical problems, navigation, spelling and grammatical errors, completion, design, use of enhancement such as graphics and sound, organization, branching, citing resources, originality, curriculum alignment and meeting the objectives, depth and breadth of the project content, subject knowledge (CK) and teamwork.

Source: Multimedia Mania 2004 - Judges' Rubric (ISTE's HyperSIG, 2004). Retrieved from http://www.ncsu.edu/mmania/mm_docs/mm_judge_rubric.html

Chapters: 5

\begin{tabular}{|c|c|c|c|c|c|}
\hline Criteria & 1.0 & 2.0 & 2.5 & 4.0 & Scores \\
\hline 胥 & $\begin{array}{l}\text { Project does not } \\
\text { run satisfactorily. } \\
\text { There are too } \\
\text { many technical } \\
\text { problems to view } \\
\text { the project. }\end{array}$ & $\begin{array}{l}\text { Project runs } \\
\text { minimally. There } \\
\text { are many technical } \\
\text { problems when } \\
\text { viewing the project. }\end{array}$ & $\begin{array}{l}\text { Project runs } \\
\text { adequately with } \\
\text { minor technical } \\
\text { problems. }\end{array}$ & \begin{tabular}{|l} 
Project runs \\
perfectly with no \\
technical problems. \\
For example, there \\
are no error \\
messages, all \\
sound, video, or \\
other files are \\
found.
\end{tabular} & \\
\hline 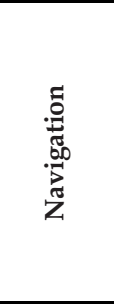 & $\begin{array}{l}\text { Buttons or } \\
\text { navigational tools } \\
\text { are absent or } \\
\text { confusing. No } \\
\text { buttons and } \\
\text { navigational tools } \\
\text { work. }\end{array}$ & $\begin{array}{l}\text { Minimal difficulty } \\
\text { experienced while } \\
\text { navigating through } \\
\text { project. }\end{array}$ & $\begin{array}{l}\text { Few difficulties } \\
\text { experienced while } \\
\text { navigating through } \\
\text { project. }\end{array}$ & $\begin{array}{l}\text { Users can progress } \\
\text { intuitively } \\
\text { throughout entire } \\
\text { project in a logical } \\
\text { path to find } \\
\text { information. All } \\
\text { buttons and } \\
\text { navigational tools } \\
\text { work. }\end{array}$ & \\
\hline 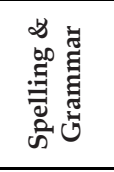 & \begin{tabular}{|l|} 
Project has \\
multiple errors in \\
spelling and/or \\
grammar. (Four or \\
more errors) \\
\end{tabular} & \begin{tabular}{|l}
$\begin{array}{l}\text { Project minimally } \\
\text { honors rules of } \\
\text { spelling and/or }\end{array}$ \\
grammar. (Three or \\
less errors)
\end{tabular} & \begin{tabular}{|l} 
Project adequately \\
honors most rules \\
of spelling and/or \\
grammar. (Two or \\
less errors)
\end{tabular} & $\begin{array}{l}\text { Project honors all } \\
\text { rules of spelling } \\
\text { and/or grammar. }\end{array}$ & \\
\hline$=$ & \begin{tabular}{|l|} 
Project is \\
incomplete and \\
contains many \\
unfinished \\
elements. \\
\end{tabular} & $\begin{array}{l}\text { Project is } \\
\text { incomplete and } \\
\text { contains some } \\
\text { unfinished } \\
\text { elements. }\end{array}$ & \begin{tabular}{|l} 
Project is \\
incomplete and \\
contains several \\
unfinished \\
elements.
\end{tabular} & $\begin{array}{l}\text { Project is } \\
\text { completely } \\
\text { finished. }\end{array}$ & \\
\hline
\end{tabular}




\begin{tabular}{|c|c|c|c|c|}
\hline 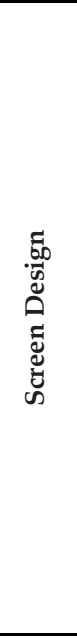 & \begin{tabular}{|l|} 
Screens are either \\
barren and stark or \\
confusing and \\
cluttered. \\
Exaggerated \\
emphasis on \\
graphics and \\
special effects \\
weakens the \\
message and \\
interferes with the \\
communication of \\
content and ideas.
\end{tabular} & \begin{tabular}{|l|} 
Multimedia \\
elements \\
accompany content \\
but there is little \\
sign of mutual \\
reinforcement. \\
There is no \\
attention to visual \\
design criteria such \\
as balance, \\
proportion, \\
harmony and \\
restraint. There is \\
some tendency \\
toward random use \\
of graphical \\
elements that do \\
not reinforce \\
message.
\end{tabular} & $\begin{array}{l}\text { Multimedia } \\
\text { elements and } \\
\text { content combine to } \\
\text { adequately deliver } \\
\text { a high impact } \\
\text { message with the } \\
\text { elements and } \\
\text { words reinforcing } \\
\text { each other. }\end{array}$ & \begin{tabular}{|l|} 
The combination of \\
multimedia \\
elements and \\
content takes \\
communication to a \\
superior level. \\
There is clear \\
attention given to \\
balance, \\
proportion, \\
harmony, and \\
restraint. The \\
synergy reaches the \\
intended audience \\
with style and \\
pizzazz.
\end{tabular} \\
\hline 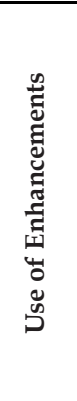 & $\begin{array}{l}\text { No graphics, } \\
\text { video, audio, 3-D, } \\
\text { or other } \\
\text { enhancements are } \\
\text { present or use of } \\
\text { these tools is } \\
\text { inappropriate. }\end{array}$ & $\begin{array}{l}\text { Limited graphics, } \\
\text { video, audio, 3-D, } \\
\text { or others } \\
\text { enhancements are } \\
\text { present but do not } \\
\text { always enrich the } \\
\text { learning } \\
\text { experience. In some } \\
\text { instances, use of } \\
\text { these } \\
\text { enhancements is } \\
\text { inappropriate. }\end{array}$ & $\begin{array}{l}\text { Most graphics, } \\
\text { video, audio, 3-D, } \\
\text { or other } \\
\text { enhancements are } \\
\text { used appropriately } \\
\text { to enrich the } \\
\text { experience. For } \\
\text { example, clips are } \\
\text { either too long or } \\
\text { too short to be } \\
\text { meaningful. }\end{array}$ & $\begin{array}{l}\text { All graphics, video, } \\
\text { audio, 3-D, or other } \\
\text { enhancements are } \\
\text { used effectively to } \\
\text { enrich the learning } \\
\text { experience. } \\
\text { Enhancements } \\
\text { contribute } \\
\text { significantly to } \\
\text { convey the } \\
\text { intended meaning. }\end{array}$ \\
\hline 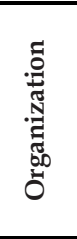 & $\begin{array}{l}\text { The sequence of } \\
\text { information is not } \\
\text { logical. Menus and } \\
\text { paths to } \\
\text { information are } \\
\text { not evident. }\end{array}$ & $\begin{array}{l}\text { The sequence of } \\
\text { information is } \\
\text { somewhat logical. } \\
\text { Menus and paths } \\
\text { are confusing and } \\
\text { flawed. }\end{array}$ & $\begin{array}{l}\text { The sequence of } \\
\text { information is } \\
\text { logical. Menus and } \\
\text { paths to most } \\
\text { information are } \\
\text { clear and direct. }\end{array}$ & $\begin{array}{l}\text { The sequence of } \\
\text { information is } \\
\text { logical and } \\
\text { intuitive. Menus } \\
\text { and paths to all } \\
\text { information are } \\
\text { clear and direct. }\end{array}$ \\
\hline 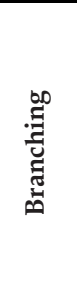 & $\begin{array}{l}\text { Project contains } \\
\text { few choices. The } \\
\text { design is linear. }\end{array}$ & $\begin{array}{l}\text { Project contains } \\
\text { few well-designed } \\
\text { and age- } \\
\text { appropriate } \\
\text { choices. The design } \\
\text { is primarily linear. }\end{array}$ & $\begin{array}{l}\text { Although project } \\
\text { contains some well- } \\
\text { designed and age- } \\
\text { appropriate } \\
\text { choices, some } \\
\text { portions are linear. }\end{array}$ & $\begin{array}{l}\text { Project is truly } \\
\text { multimedia, rather } \\
\text { than linear and } \\
\text { contains a } \\
\text { significant number } \\
\text { of well-designed } \\
\text { and age- } \\
\text { appropriate } \\
\text { choices. }\end{array}$ \\
\hline 我事 & $\begin{array}{l}\text { No sources are } \\
\text { properly cited } \\
\text { within the project }\end{array}$ & $\begin{array}{l}\text { Few sources are } \\
\text { properly cited } \\
\text { within the project }\end{array}$ & $\begin{array}{l}\text { Most sources are } \\
\text { properly cited } \\
\text { within the project }\end{array}$ & $\begin{array}{l}\text { All sources are } \\
\text { properly cited } \\
\text { within the project }\end{array}$ \\
\hline
\end{tabular}




\begin{tabular}{|c|c|c|c|c|}
\hline 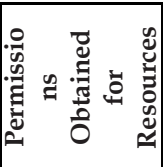 & $\begin{array}{l}\text { No permissions to } \\
\text { use text, graphics, } \\
\text { audio, video, etc. } \\
\text { are available. }\end{array}$ & $\begin{array}{l}\text { Few permissions to } \\
\text { use text, graphics, } \\
\text { audio, video, etc. } \\
\text { are available. }\end{array}$ & $\begin{array}{l}\text { Most permissions } \\
\text { to use text, } \\
\text { graphics, audio, } \\
\text { video, etc. are } \\
\text { available. }\end{array}$ & $\begin{array}{l}\text { All permissions to } \\
\text { use text, graphics, } \\
\text { audio, video, etc. } \\
\text { are available. }\end{array}$ \\
\hline 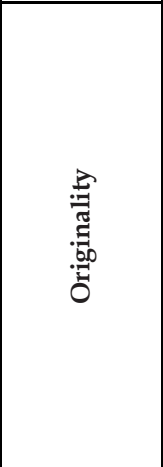 & $\begin{array}{l}\text { The work is a } \\
\text { minimal collection } \\
\text { or rehash of other } \\
\text { people's ideas, } \\
\text { products, images } \\
\text { and inventions. } \\
\text { There is no } \\
\text { evidence of new } \\
\text { thought. }\end{array}$ & $\begin{array}{l}\text { The work is an } \\
\text { extensive collection } \\
\text { and rehash of other } \\
\text { people's ideas, } \\
\text { products, images } \\
\text { and inventions. } \\
\text { There is little } \\
\text { evidence of new } \\
\text { thought or } \\
\text { inventiveness. }\end{array}$ & $\begin{array}{l}\text { The project shows } \\
\text { some evidence of } \\
\text { originality and } \\
\text { inventiveness. } \\
\text { While based on an } \\
\text { extensive collection } \\
\text { of other people's } \\
\text { ideas, products, } \\
\text { images and } \\
\text { inventions, the } \\
\text { work extends } \\
\text { beyond that } \\
\text { collection to offer } \\
\text { new insights. }\end{array}$ & $\begin{array}{l}\text { The project shows } \\
\text { significant } \\
\text { evidence of } \\
\text { originality and } \\
\text { inventiveness. The } \\
\text { majority of the } \\
\text { content and many } \\
\text { of the ideas are } \\
\text { fresh, original, and } \\
\text { inventive. }\end{array}$ \\
\hline 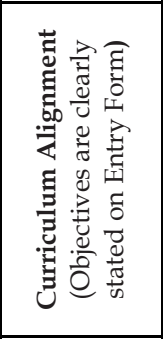 & $\begin{array}{l}\text { No evidence of } \\
\text { connection to } \\
\text { target curriculum. } \\
\text { Users are not likely } \\
\text { to learn from this } \\
\text { project. }\end{array}$ & $\begin{array}{l}\text { Some evidence of } \\
\text { connection to target } \\
\text { curriculum. Users } \\
\text { may learn from this } \\
\text { project. }\end{array}$ & $\begin{array}{l}\text { Adequate evidence } \\
\text { of connection to } \\
\text { target curriculum. } \\
\text { Users are likely to } \\
\text { learn from this } \\
\text { project. }\end{array}$ & \begin{tabular}{|l|} 
Clear evidence of \\
connection to target \\
curriculum. \\
Frequent and clear \\
references are \\
made to facts, \\
concepts, and cited \\
resources. Users \\
will learn from this \\
project.
\end{tabular} \\
\hline 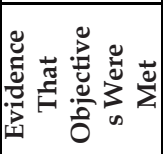 & $\begin{array}{l}\text { No evidence that } \\
\text { project content } \\
\text { supports stated } \\
\text { objectives. }\end{array}$ & $\begin{array}{l}\text { Little evidence that } \\
\text { project content } \\
\text { supports stated } \\
\text { objectives. }\end{array}$ & $\begin{array}{l}\text { Some evidence that } \\
\text { project content } \\
\text { supports stated } \\
\text { objectives. }\end{array}$ & $\begin{array}{l}\text { Clear evidence that } \\
\text { project content } \\
\text { supports stated } \\
\text { objectives. }\end{array}$ \\
\hline 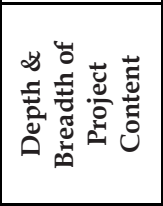 & $\begin{array}{l}\text { No evidence that } \\
\text { higher level } \\
\text { thinking skills } \\
\text { were used in the } \\
\text { creation of this } \\
\text { project. }\end{array}$ & $\begin{array}{l}\text { Little evidence that } \\
\text { higher level } \\
\text { thinking skills were } \\
\text { used in the creation } \\
\text { of this project. }\end{array}$ & $\begin{array}{l}\text { Some evidence that } \\
\text { higher level } \\
\text { thinking skills were } \\
\text { used in the creation } \\
\text { of this project. }\end{array}$ & $\begin{array}{l}\text { Clear evidence that } \\
\text { higher level } \\
\text { thinking skills were } \\
\text { used in the creation } \\
\text { of this project. }\end{array}$ \\
\hline 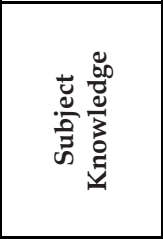 & $\begin{array}{l}\text { Subject knowledge } \\
\text { is not evident. } \\
\text { Information is } \\
\text { confusing, } \\
\text { incorrect, or } \\
\text { flawed. }\end{array}$ & $\begin{array}{l}\text { Some subject } \\
\text { knowledge is } \\
\text { evident. Some } \\
\text { Information is } \\
\text { confusing, } \\
\text { incorrect, or } \\
\text { flawed. }\end{array}$ & $\begin{array}{l}\text { Subject knowledge } \\
\text { is evident in much } \\
\text { of the project. Most } \\
\text { information is } \\
\text { clear, appropriate, } \\
\text { and correct. }\end{array}$ & $\begin{array}{l}\text { Subject knowledge } \\
\text { is evident } \\
\text { throughout the } \\
\text { project. All } \\
\text { information is } \\
\text { clear, appropriate, } \\
\text { and correct. }\end{array}$ \\
\hline Е & Team not active. & $\begin{array}{l}\text { Team partially } \\
\text { active. }\end{array}$ & Team active. & Team highly active. \\
\hline
\end{tabular}

${ }^{*}$ Added by researcher 
